\title{
Receituário agronômico: a construção de um instrumento de apoio à gestão dos agrotóxicos e sua controvérsia
}

\author{
José Prado Alves Filho
}

Dissertação apresentada ao Programa de Pós-Graduação em Ciência Ambiental da Universidade de São Paulo - PROCAM - USP, como parte dos requisitos para a obtenção do título de Mestre em Ciência Ambiental.

Orientador : Prof. Dr. Ricardo Abramovay

Universidade de São Paulo 
Ficha Catalográfica

Alves Filho, José Prado

A474r Receituário agronômico: a construção de um instrumento de apoio à gestão dos agrotóxicos e sua controvérsia / José Prado Alves Filho. -- São Paulo, 2000.

Dissertação (Mestrado) -- Programa de Pós-Graduação em Ciência Ambiental - Universidade de São Paulo, 2000.

Orientador: Prof. Dr. Ricardo Abramovay

1. Agrotóxicos - Pesticidas. 2. Produtos químicos - Controle. 3. Segurança Química. 4. Meio Ambiente. 5. Agricultura. I. Título. 
A meus pais, Maria Inês e José, e à Eva, Mariana e Zéca, pontos de força e luz em minha rede de afetos, dedico este trabalho. 


\section{AGRADECIMENTOS}

Ao Prof. Dr. Ricardo Abramovay, pela acolhida como orientador, pelos estímulos, disponibilidade, colaboração e atenção sempre presente na construção deste estudo.

Ao Prof. Dr. José Juliano de Carvalho Filho, pela acolhida e orientação inicial junto ao Programa de Pós Graduação em Ciência Ambiental da Universidade de São Paulo.

Aos Professores Drs. José Eli Savoia da Veiga e Ângelo Zanaga Trapé, pelas valiosas sugestões ao aprimoramento deste trabalho.

Aos Engenheiros Agrônomos Sebastião Pinheiro, Walter Lazzarini, José Pedro da Costa Santiago, Reinaldo Onofre Skalisz, José Rubens Pelegrinete, Clayton Campanhola, Francisco Roberto Caporal, Valdir Antonio Secchi, e José Suzano de Almeida, pela atenção e disponibilidade no fornecimento de proveitosas informações e relatos sobre suas experiências à cerca do tema estudado.

Ao Eng ${ }^{\circ}$ Agrônomo Eduardo Garcia Garcia, por assumir a Divisão de Agrotóxicos da Coordenação de Segurança Rural da FUNDACENTRO, em meus períodos de afastamento para elaboração deste trabalho, pelo estímulo, e pelo enriquecimento profissional e pessoal construídos ao longo destes doze anos de convivência e trabalho.

À Susanna Acel, pela colaboração na composição do abstract.

À equipe da Divisão de Documentação e Biblioteca da FUNDACENTRO, pelo apoio nas pesquisas bibliográficas.

À FUNDACENTRO pelo apoio institucional e logístico.

A todos que de alguma forma contribuíram para a realização deste trabalho. 
ÍNDICE DE FIGURAS ........................................................................................ vii

INDICE DE TABELAS............................................................................................. $\mathrm{x}$

INDICE DE ABREVIATURAS E SIGLAS ............................................... xii

RESUMO ................................................................................................................. xiv

ABSTRACT ............................................................................................................... $\mathrm{xV}$

1. APRESENTAÇÃO ...........................................................................................16

2. UMA VISÃO GERAL SOBRE OS AGROTÓXICOS ........................... 33

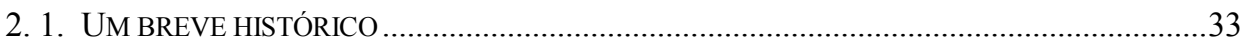

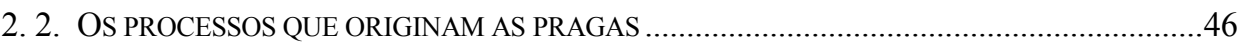

2. 3. O CONSUMO MUNDIAL DE AGROTÓXICOS.............................................................53

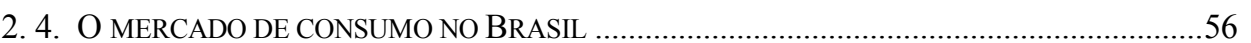

\section{A DIFUSÃO DO CONTROLE QUÍMICO NA AGRICULTURA}

BRASILEIRA............................................................................................................ 71

3. 1. A CONSOLIDAÇÃO DO USO DE AGROTÓXICOS NO BRASIL ...........................................73

3. 2. A CRIAÇÃO DA ANDEF ................................................................................... 78

3. 3. O PAPEL DO CRÉDITO RURAL NO CRESCIMENTO DO MERCADO .............................82

3. 4. O INCREMENTO DO USO E A PERCEPÇÃO DOS IMPACTOS À SAÚDE E AO AMBIENTE .....84

4. A RECEITA BRASILEIRA NO CONTROLE DOS RISCOS........... 108

4. 1. A CONSTRUÇÃO DOS CONCEITOS EM TORNO DO RECEITUÁRIO .................................125

5. PERDENDO O PONTO DA RECEITA: AS CONTROVÉRSIAS

MODIFICANDO A IDÉIA INICIAL ........................................................139

5. 1. O ESTABELECIMENTO DO DEBATE .......................................................................139

5. 2. AS DIFICULDADES DE IMPLANTAÇÃO E OPERAÇÃO DO SISTEMA ................................151

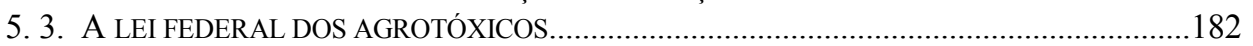

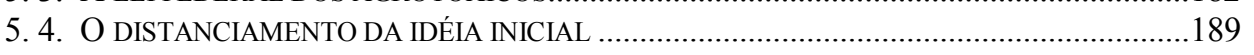

6. O FEITIÇO VIRA CONTRA O FEITICEIRO: A BANALIZAÇÃO DAS

ATIVIDADES DO RECEITUÁRIO_...........................................................192

6. 1. A INEFICÁCIA DO SISTEMA DE RECEITUÁRIO AGRONÔMICO .......................................201 
7. CONCLUSÃO: QUEBRANDO O FEITIÇO E BUSCANDO A RECEITA DO ANTIDOTO ....................................................................................................................218

8. REFERÊNCIAS BIBLIOGRÁFICAS.................................................... 224 


\section{ÍNDICE DE FIGURAS}

Página

Figura 1 - Resumo dos principais argumentos favoráveis e contrários em relação ao uso de agrotóxicos.

Figura 2 - Divisão mundial do mercado de agrotóxicos em geral e em suas principais classes de uso - 1992 .

Figura 3 - Vendas de agrotóxicos, segundo as principais classes de uso. Brasil 1972 a 1982 - (em US\$ 1000 de 1999).

Figura 4 - Vendas de agrotóxicos, segundo as principais classes de uso. Brasil 1982 a 1992 - (em US\$ 1000 de 1999)

Figura 5 - Vendas de agrotóxicos, segundo as principais classes de uso. Brasil 1992 a 1999 - (em US\$ 1000 de 1999).

Figura 6 - Vendas* de agrotóxicos no Brasil, em 1985 e 1996, segundo as unidades da federação

Figura 7 - Distribuição dos produtos registrados no Ministério da Agricultura, segundo classes gerais de uso - Brasil - 1998.

Figura 8 - Distribuição percentual dos casos registrados no SINITOX, de intoxicação humana, por agente tóxico - Brasil - 1998.

Figura 9 - Distribuição percentual dos casos registrados de intoxicação humana, que evoluíram a óbito e agente tóxico - Brasil - 1998

Figura 10 - Evolução dos casos de intoxicação humana por agrotóxicos registrados pelo SINITOX* e das vendas de agrotóxicos** nos anos de 1992 a 1998. 
Figura 11 - Modelo de "Bloco de Recomendações Técnicas" utilizado pelo Serviço de Extensão Rural no Rio Grande do Sul, anterior à implantação do receituário (1978).

Figura 12 - Carta-circular do Banco do Brasil, destinada às agências do Estado do Rio Grande do Sul, instituindo o receituário agronômico nas operações de crédito efetuadas pelo banco. Brasília, fevereiro de 1978.

Figura 13 - Recomendação $\mathrm{n}^{\mathrm{o}} 01$ da Comissão de Defensivos Agrícolas, aprovada em 17 de outubro de 1978

Figura 14 - Quadro resumo dos argumentos apresentados por Lutzemberger, no debate em torno da resolução $\mathrm{n}^{\circ} 01$ da Comissão de Defensivos Agrícolas.

Figura 15 - Carta do Banco do Brasil, dirigida ao presidente da Sociedade de Agronomia do Rio Grande do Sul, dando conta dos resultados preliminares decorrentes da adoção do receituário agronômico (1980)

Figura 16 - Modelo de receituário agronômico adotado pela EMATER-RS, em 1978 (frente e verso).

Figura 17 - Tópicos do conteúdo programático desenvolvido no " $1^{\circ}$ Curso sobre Fundamentos do Receituário Agronômico", e respectivos docentes. Pelotas, RS, abril de 1978.

Figura 18 - Alguns componentes do "Glossário de termos e conceitos em Receituário Agronômico", apresentado no " $1^{\circ}$ Curso sobre Fundamentos do Receituário Agronômico". Pelotas/RS 1978

Figura 19 - Perguntas básicas para o procedimento de anamnese ativa no exercício do receituário agronômico...

Figura 20 - Modelo de Ficha Técnica

Figura 21 - Fatores determinantes da eficiência do receituário.

Figura 22 - Apoio logístico ao receituário agronômico - subsídios.

Figura 23 - Aspectos comparativos entre o "receituário agronômico" e o "projeto fitossanitário".

Figura 24 - Obstáculos e perspectivas inicias para a implantação da proposta de receituário agronômico , Brasil - 1979-80. 
Figura 25 - Evolução dos índices percentuais simples das quantidades vendidas de produto comercial, em diversas classes de agrotóxicos - Brasil 1978, 1988 e 1998 (ano base 1975=100)..

Figura 26 - Evolução dos índices percentuais simples das quantidades vendidas de ingrediente ativo, em diversas classes de agrotóxicos - Brasil 1978, 1988 e 1998 (ano base 1975=100)

Figura 27 - Evolução dos índices percentuais de produtividade, área plantada, produção, valor de vendas de herbicidas e quantidades de ingredientes ativos de herbicidas utilizados na cultura da soja. Brasil - 1985 e 1998 (ano base 1984=100).

Figura 28 - Esquema geral do trabalho de tratamento e aplicação dos dados do receituário agronômico desenvolvido pela Embrapa Meio Ambiente..

Figura 29 - Funcionamento do sistema integrado de avisos (SAI)

Figura 30 - Exemplos de páginas na internet disponibilizando a compra de agrotóxicos através do comércio eletrônico. 


\section{ÍNDICE DE TABELAS}

Página

Tabela 1 - Ações regulatórias da EPA e situação especial de revisão de agrotóxicos usados na produção agrícola

Tabela 2 - Produção global atual de oito principais culturas e perdas estimadas, por tipos de pragas, no período de 1988 e 90 - (bilhões US\$)

Tabela 3 - Produção global atual e perdas estimadas de oito principais culturas, no período de 1988 e 90, por tipos de pragas e regiões - (bilhões de US\$)

Tabela 4 - Despesas* com agrotóxicos em alguns países da América Latina

Tabela 5 - Vendas de agrotóxicos (US\$ milhões) nos países do Mercosul, segundo as principais classes de uso, 1995

Tabela 6 - Vendas mundiais de agrotóxicos realizadas pelas principais empresas produtoras em 1993

Tabela 7 - Vendas de agrotóxicos - Brasil - 1972 - 1989 e 1997-1998

Tabela 8 - Vendas de inseticidas ${ }^{1}$ - Brasil - 1972 - 1989 e 1997-1998..................... 58

Tabela 9 - Vendas de fungicidas - Brasil - 1972 - 1989 e 1997-1998.................... 59

Tabela 10 - Vendas de herbicidas - Brasil - 1972 - 1989 e 1997-1998..................... 60

Tabela 11 - Participação das principais empresas atuantes no mercado de agrotóxicos no Brasil, no ano de 1999

Tabela 12 - Participação das principais empresas atuantes no mercado de agrotóxicos no Brasil, no ano de 1999, após os processos de fusões comerciais 
Tabela 13 - Número de ingredientes ativos com uso permitido no país, segundo as classes de uso e classes toxicológicas a que pertencem. Brasil 1996 a 2000

Tabela 14 - Número de produtos comerciais com uso permitido no país, segundo as classes de uso e classes toxicológicas a que pertencem.

Brasil - 1996 a 2000.

Tabela 15 - Número de apresentações de produtos comerciais com uso permitido no país, segundo as classes de uso e classes toxicológicas a que pertencem. Brasil - 1996 a 2000

Tabela 16 - Brasil - Agrotóxicos* - Produção, Importação, Exportação e Consumo Aparente - 1970 - 84 (em toneladas)**

Tabela 17 - Financiamento concedido a Produtores e Cooperativas Agrícolas pelo Sistema Nacional de Crédito Rural, para custeio agrícola e aquisição de agrotóxicos - Brasil - 1974 - 1981

Tabela 18 - Evolução da participação percentual das principais culturas, no valor total dos financiamentos concedidos a produtores e cooperativas para aquisição de agrotóxicos , Brasil , 1977 - 1981

Tabela 19 - Evolução dos casos registrados no SINITOX, de intoxicação humana, por agente causal geral e por pesticidas agropecuários, em situação de exposição geral e exposição ocupacional - Brasil - 1999...

Tabela 20 - Quantidades* de agrotóxicos comercializados, em produto comercial e ingrediente ativo, segundo as diferentes classes de produtos - Brasil - 1987 e 1997. 


\section{ÍNDICE DE ABREVIATURAS E SIGLAS}

\begin{tabular}{|c|c|}
\hline AENORGS & $\begin{array}{l}\text { Associação dos Engenheiros Agrônomos do Nordeste do Rio } \\
\text { Grande do Sul }\end{array}$ \\
\hline AGAPAN & Associação Gaúcha de Proteção ao Ambiente Natural \\
\hline ANDEF & $\begin{array}{l}\text { Associação Nacional de Defesa Vegetal (até } 1992 \text { denominada } \\
\text { como Associação Nacional de Defensivos Agrícolas) }\end{array}$ \\
\hline ART & Anotação de Responsabilidade Técnica \\
\hline $\mathrm{BHC}$ & Hexaclorociclohexano \\
\hline $\mathrm{CCI}$ & Centro de Controle de Intoxicações \\
\hline CNARA & Congresso Nacional de Agrotóxicos e Receituário Agronômico \\
\hline CONFEA & Conselho Federal de Engenharia, Arquitetura e Agronomia \\
\hline $\mathrm{CPA}$ & Conselho de Política Aduaneira \\
\hline CREA & Conselho Regional de Engenharia, Arquitetura e Agronomia \\
\hline DDT & Dicloro Difenil Tricloroetano \\
\hline EBDC & Ethylene bisdithiocarbamic acid \\
\hline EMATER & Empresa de Assistência Técnica e Extensão Rural \\
\hline EPA & Environmental Protection Agency \\
\hline EUA & Estados Unidos da América \\
\hline FAEAB & Federação das Associações de Engenheiros Agrônomos do \\
\hline & Brasil \\
\hline FAEM & Faculdade de Agronomia "Eliseu Maciel" \\
\hline FAO & Food and Agriculture Organization of United Nations \\
\hline FIOCRUZ & Fundação Instituto Oswaldo Cruz \\
\hline FUNDACENTRO & Fundação Jorge Duprat Figueiredo de Segurança e Medicina do \\
\hline & Trabalho \\
\hline IEA & Instituto de Economia Agrícola \\
\hline
\end{tabular}


MIP

MS

OECD

OMS

PAHO

PND

PNDA

PRONAF

SINDAG

SINITOX

UBV

UFPel

Unesp

USP
Manejo Integrado de Pragas

Ministério da Saúde

Organization for Economic Co-operation and Development

Organização Mundial de Saúde

Pan American Health Organization

Plano Nacional de Desenvolvimento

Plano Nacional de Defensivos Agrícolas

Programa Nacional de Fortalecimento da Agricultura Familiar

Sindicato Nacional das Indústrias de Defensivos Agrícolas

Sistema Nacional de Informações Tóxico-Farmacológicas

Ultra Baixo Volume

Universidade Federal de Pelotas

Universidade Estadual Paulista

Universidade de São Paulo 


\section{RESUMO}

ALVES FILHO, J. P. (2000). Receituário agronômico: a construção de um instrumento de apoio à gestão dos agrotóxicos e sua controvérsia. São Paulo, 2000. 235p. Dissertação (Mestrado) Programa de Pós-Graduação em Ciência Ambiental, Universidade de São Paulo.

O uso indiscriminado de agrotóxicos na agricultura brasileira, e suas conseqüências sobre os aspectos ambientais e de saúde pública, deram início a uma ampla campanha conduzida por agrônomos, extensionistas, ambientalistas e produtores rurais, visando a criação de mecanismos de controle do uso desses insumos químicos. Um dos caminhos construídos no Brasil para a gestão dos agrotóxicos foi o estabelecimento, através de legislação específica, da prescrição técnica obrigatória, a partir da participação de um profissional habilitado (engenheiro agrônomo ou florestal), como requisito para a comercialização dos agrotóxicos. O presente estudo visa discutir a situação atual de aplicação e uso do receituário agronômico, comparando os princípios que fundamentaram no passado a construção desse instrumento de gestão, com o quadro atual de utilização dessa prática. A parte inicial deste estudo apresenta um panorama geral sobre o uso de agrotóxicos. Em seguida, buscou-se investigar e discutir os fatores de origem da adoção do receituário agronômico, a partir do desenho de um quadro histórico do processo de proposição e adoção desse instituto. O passo seguinte foi dedicado a investigar as influências do processo de institucionalização do receituário agronômico e as distorções ocorridas em relação aos preceitos iniciais da proposta. Buscou-se também registrar subsídios sobre o atual contexto de aplicação e aplicabilidade do receituário agronômico.

Palavras-chave: agrotóxicos; pesticidas; segurança química; meio ambiente. 


\section{ABSTRACT}

ALVES FILHO, J. P. (2000). Agronomic prescription: the creation of a pesticides management support tool and its controversy. São Paulo, 2000. 235p. Dissertação (Mestrado) - Programa de PósGraduação em Ciência Ambiental, Universidade de São Paulo.

The unrestricted use of pesticides in Brazilian agriculture and its impact in environmental and public health aspects, motivated a broad range of initiatives conducted by agronomists, professionals of rural extension services, environmentalists and farmers, with the objective of creating new mechanisms of pesticides control. One of the ways built in Brazil for the management of pesticides was the establishment, through a specific legislation, of the mandatory technical prescription, written by a qualified professional (agronomist or forest engineer), as a requirement to pesticides commercialization. The aim of this study is to discuss the status of agronomic prescription use, comparing the principles that supported the construction of this management tool in the past with the adoption of this practice nowadays. The initial part of this study presents a general panorama on the use of pesticides in the agriculture. Soon afterwards, it was looked for to investigate and to discuss the factors of origin of the adoption of the agronomics prescriptions, starting from the drawing of a historical picture of the proposition process and adoption of that institute. The following step was dedicated to the investigation on the influences of the process of adoption of the technical prescription and the distortions happened in relation to the initial precepts of the proposal. It was also looked for to register subsidies on the current application context and applicability of the agronomics prescriptions.

Keywords: pesticides; chemical safety; environment 


\section{APRESENTAÇÃO}

A implantação e adoção generalizada, da prática do que se convencionou chamar de "receituário agronômico", a partir da aprovação da legislação federal (Lei nº 7.802, de 11 de julho de 1989) que regulamenta o uso dos agrotóxicos no país, representa tentativa quase inédita de controle da comercialização e da utilização desses produtos, quando analisamos as estratégias de gestão adotadas em outros países, na busca de padrões e recomendações técnicas que possam minimizar os efeitos negativos decorrentes do uso de agrotóxicos ${ }^{\mathrm{i}}$.

A prescrição técnica formalizada, como instrumento legal obrigatório para a compra destes insumos, representou um dos caminhos institucionais construídos no Brasil para se tentar reverter os graves problemas ambientais e de saúde pública desenhados pelo uso indiscriminado de agrotóxicos nas atividades agropecuárias e florestais.

O processo que culminou com a proposição desse sistema de controle da comercialização dos agrotóxicos por receita, pode ser caracterizado como socialmente construído. Ele é o resultado de um amplo debate que ocupou a agenda de vários atores sociais envolvidos com os temas ambientais e a questão dos agrotóxicos, em especial nos meios agronômicos, desde o final da década de 70 .

\footnotetext{
${ }^{\text {i }}$ O Brasil não foi o pioneiro na exigência de autorização escrita para a venda de agrotóxicos. Países como a Venezuela e a Polônia já praticavam tal controle bem antes do início das discussões no Brasil, sendo que na Polônia a prática existe desde 1965. Entretanto o surgimento da figura do engenheiro agrônomo como mediador dessa relação surge apenas na década de setenta, a partir da implantação na Califórnia, Estados Unidos, de um sistema de credenciamento desses profissionais para a autorização de vendas de agrotóxicos (GUERRA \& SAMPAIO,1991).
} 
A rede sócio-técnica (LATOUR, 1994) constituída por legisladores, extensionistas, ambientalistas, agricultores e suas organizações, e principalmente pela corporação agronômica, através de suas associações e conselhos profissionais, constrói e modifica o instrumento do receituário e dessa forma vai definindo as relações estabelecidas entre extensionista e agricultor, agrotóxicos e pragas, saúde e doença, contaminação e preservação do ambiente.

Decorridos mais de dez anos desde a aprovação da "Lei dos Agrotóxicos", marco da implantação prática do receituário agronômico em todo o país, é patente sua ineficácia como instrumento de apoio à gestão desses insumos.

A ausência quase que total de qualquer tipo de processamento e acompanhamento por parte dos órgãos fiscalizadores das áreas de defesa agropecuária e de fiscalização do exercício profissional (Sistema CONFEA/CREA), das informações constantes das receitas emitidas, constitui apenas uma parte das inúmeras evidências empíricas sobre a ineficácia deste sistema de controle.

Não obstante os sinais explícitos de sua ineficácia, paradoxalmente o ritual do receituário agronômico continua a ser cultivado pela rede de atores envolvidos, contando inclusive com a realização de congressos anuais promovidos pela corporação agronômica. Nesses eventos se pode constatar o debate travado entre os que buscam ressaltar seus efeitos positivos e aqueles mais críticos que questionam sua concepção e funcionalidade.

A reflexão sobre este quadro inspirou a realização da presente pesquisa, cujos objetivos são os seguintes:

- estudar a história e o contexto de adoção do receituário agronômico, verificando os processos sociais que resultaram na proposição desse instrumento de regulação do uso de agrotóxicos na atividade agropecuária; 
- analisar o papel da corporação agronômica (técnicos, pesquisadores, extensionistas, universidade, conselhos e associações profissionais, etc) e da indústria de agrotóxicos na construção e manutenção do sistema de receituário implantado;

- investigar a situação atual de aplicação e uso do receituário e contribuir para uma abordagem mais crítica sobre a necessidade de rever os mecanismos de controle dos agrotóxicos no Brasil, em especial no que se refere às estratégias que buscam definir as relações de mediação técnica para o acesso aos agrotóxicos, como tentativa de minimizar os fatores de riscos associados a esses insumos.

As idéias que catalisaram a iniciativa de proposição e desenvolvimento do presente estudo surgiram como decorrência de minha vivência profissional, em doze anos dedicados à pesquisa e extensão de conceitos e técnicas de prevenção de acidentes de trabalho na agricultura, atuando como pesquisador da Divisão de Agrotóxicos da Coordenação de Segurança Rural da FUNDACENTRO, somados a dois anos de atividades de assessoria na elaboração e aplicação de estratégias de fiscalização da atividade profissional do engenheiro agrônomo, como fiscal técnico da Câmara de Agronomia do CREA-SP, nos anos de 1986 a 1988.

Os contatos com a temática ambiental e ocupacional ligada aos agrotóxicos foram fatores que alimentaram a preocupação com a questão do uso desses insumos no campo e suas conseqüências influenciando a definição das condições dos ambientes de trabalho nas atividades agrícolas e florestais, a segurança e saúde do trabalhador exposto a esse risco, a qualidade ambiental das áreas submetidas ao emprego desses insumos, e finalmente a qualidade dos alimentos e da água que consumimos. As visões gerais de todas estas interfaces de implicações e relações serviram como motivação para a realização desta pesquisa especialmente dentro de um contexto de abordagem multidisciplinar proporcionada pela concepção somada ao ambiente que inspira a existência do PROCAM - Programa de Pós-Graduação em Ciência Ambiental da Universidade de São Paulo. 
Um ponto específico de interesse dentro da questão mais ampla relativa ao uso de agrotóxicos situa-se na forma como são construídos e aplicados os processos de disseminação da tecnologia química, como instrumento de controle dos problemas fitossanitários na atividade agropecuária e florestal, e o papel exercido pelos atores responsáveis pela recomendação técnica no emprego desses insumos.

Os problemas decorrentes do uso intenso desses insumos no campo continuam a desenhar um quadro de gravidade, tanto na produção de intoxicações de trabalhadores expostos, como na contaminação ambiental desencadeada pelas aplicações indiscriminadas e desprovidas de efetiva orientação e acompanhamento técnico.

A importância e a atualidade da questão dos agrotóxicos no Brasil pode ser constatada quando se verifica a atenção dada ao tema no conteúdo construído para a Agenda 21 Brasileira", em especial na área temática dedicada a "Agricultura Sustentável". Tanto o documento final como os diversos relatórios produzidos reservam vários tópicos dedicados a diagnosticar os problemas decorrentes do uso atual da tecnologia química, trazendo também sugestões de estratégias e diretrizes para a redução e fiscalização do uso desses insumos, visando o manejo sustentável dos sistemas produtivos.

Um dos relatórios produzidos como subsídios à composição da Agenda 21 brasileira aponta que "não é de se espantar que em torno dos agrotóxicos se desenvolvam as mais acesas polêmicas, quando se trata da relação entre agricultura e meio ambiente. Em primeiro lugar a magnitude dos interesses em jogo é gigantesca...o setor faturou, em 1997, quase US\$2,2 bilhões, US\$ 200 milhões a mais que no ano anterior." (ABRAMOVAY, 1999:14).

A constatação do aumento no consumo dos agrotóxicos pode sugerir a intensificação dos problemas decorrentes de saúde pública e meio ambiente;

\footnotetext{
i Resumo do documento final e demais documentos de trabalho consultados [on line] via www, URL: http://www.atech.br/agenda21.as/final2a.htm
} 
intensificação esta que fica ainda mais clara quando se analisa o contexto em que se dá esse aumento, nas principais regiões consumidoras, como no caso do estado do Paraná: "...a indústria registra princípios ativos que não serão captados pela capacidade laboratorial existente. Os produtos proibidos (o que não significa, é claro, que não sejam usados) são monitorados, mas nunca mais, após 1984, houve a consolidação dos dados estaduais a seu respeito" (ABRAMOVAY, 1999:15).

Os casos de intoxicações humanas são registrados de forma crescente, na medida em que os sistemas de vigilância vão sendo implantados e aperfeiçoados no País. O Sistema de Informações Tóxico-farmacológicas - SINITOX, mantido pelo Ministério da Saúde, registrou a ocorrência de nada menos do que 5.268 casos de intoxicações agudas por agrotóxicos no ano de 1998. Estes registros colocam os agrotóxicos como o quarto principal agente causal de intoxicações detectadas pelo sistema.

O uso crescente nem sempre está associado a uma assistência e um contexto tecnológico adequados. Alguns estudos tentando levantar a real situação de uso desses insumos no campo têm demonstrado que a utilização muitas vezes se dá de forma completamente desprovida do acompanhamento técnico.

Um levantamento de campo realizado pela Secretaria de Agricultura e Abastecimento do Estado de São Paulo em convênio com a FUNDACENTRO no ano de 1997 mostrou que dentre cerca de 3000 unidades rurais de produção visitadas, em 100 municípios do Estado de São Paulo, 57\% dos responsáveis entrevistados relataram não receber nenhum tipo de assistência técnica por parte de agrônomos, no desenvolvimento de atividades de manejo fitossanitário (RAMOS, et al., 1999).

Em relação ao aprendizado sobre técnicas no manuseio de agrotóxicos a distribuição percentual dos entrevistados mostrou que apenas 14,8\% obtiveram orientação fornecida por técnicos (extensionistas, técnicos de cooperativas, técnicos das revendas ou técnicos particulares). Os demais relataram a seguinte situação: 39,5\% foram orientados por familiares; $16,6 \%$ por outro agricultor; $15,4 \%$ tinham o 
empregador como fonte de aprendizado; 4,9\% aprenderam com outros não enquadrados nas categorias anteriores; e por fim, $8,8 \%$ dos entrevistados relataram não ter acesso a nenhuma fonte de aprendizado para o manuseio de agrotóxicos (VICENTE et al.,1998; RAMOS, et al., 1999).

Não obstante as evidências de sua insuficiência, a receita, como etapa necessária para o acesso à tecnologia química no controle de pragas e doenças, permanece estabelecida no cotidiano das atividades agropecuárias e florestais que fazem uso dos agrotóxicos.

Tal presença se dá como mero ritual burocrático, desprovido de função e eficácia, tanto em seu preconizado caráter de instrumento de gestão de riscos químicos, como em seu papel potencial na prospecção de dados epidemiológicos sobre incidências de pragas e doenças, e consumo de agrotóxicos. Somente no Estado de São Paulo são emitidas mensalmente cerca de 40.000 receitas, que não recebem nenhum tipo de processamento e tratamento de dados por parte dos órgãos responsáveis por fiscalizar o uso - a defesa agropecuária - , ou pela fiscalização profissional da atividade agronômica e florestal - os conselhos profissionais ${ }^{\text {i. }}$.

Este quadro atual que define a situação a que foi resumida a idéia do receituário agronômico não guarda relação coerente com a visão inicial de seus proponentes, em especial junto a um seleto grupo de agrônomos e ambientalistas envolvidos na luta por sua implantação desde o final dos anos 70 .

Foi nesse período que a rede formada por técnicos da área agronômica, ambientalistas, professores universitários, dentre outros, contou com a participação de personagens de destaque, inicialmente com atuação em âmbito local (a começar pelo Estado do Rio Grande do Sul), e em seguida ganhando espaço em escala nacional, encaminhando a luta pela instituição do instrumento do Receituário Agronômico.

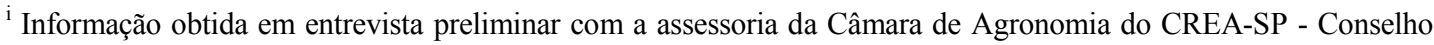
Regional de Engenharia, Arquitetura e Agronomia do Estado de São Paulo.
} 
Nomes como José Lutzenberger, Sebastião Pinheiro, Milton de Souza Guerra, Daiser Paulo Sampaio, Antenor Ferrari, Caio Lustosa, Luiz Carlos Pinheiro Machado, Verena Nygaard, Walter Lazzarini, Adilson Paschoal, Francisco Graziano Neto, dentre outros, deram o impulso inicial e alimentaram, ao final da década de 70, uma ampla campanha de adoção do Receituário Agronômico como instrumento de gestão dos impactos ambientais e de saúde pública decorrentes do uso de agrotóxicos.

Inicialmente o receituário foi concebido como instrumento metodológico de implantação de doutrina técnica renovadora para fazer frente aos problemas fitossanitários. Nesta doutrina o papel do agrônomo refletia o atendimento a interesses de produção, saúde humana, saúde animal e ambiental; a adoção da tecnologia química estaria sendo feita levando-se em conta os aspectos sócio-culturais dos usuários. $\mathrm{O}$ técnico extensionista atuaria de forma presente acompanhando e assessorando na organização do processo produtivo, buscando soluções criativas comprometidas com a resolução do problema representado pelas pragas, mas considerando a distribuição do agente etiológico, buscando reduzir o consumo de agrotóxicos a um mínimo indispensável, e dessa forma reduzir os custos de produção.

Posteriormente a massificação da prática do receituário em todo o país foi acompanhada de um processo de distanciamento dos conceitos iniciais que inspiraram a proposição deste instituto. Assim, a idéia do receituário agronômico como prática profissional ampla e baseada em doutrina técnica para o manejo fitossanitário foi sendo reduzida a uma simples preocupação operacional em torno da instituição da receita como instrumento de controle de vendas de insumos químicos reconhecidamente problemáticos.

Finalmente, nos padrões atuais, o receituário foi banalizado como mera formalidade burocrática desprovida de sentido prático em relação às suas vocações anteriores, mas dotada de papel importante para a viabilização da continuidade do processo de disseminação do uso de agrotóxicos, agora exercitado sob leis e regulamentos que diluem a responsabilidade decorrente da adoção dessa tecnologia 
entre os diversos atores participantes da rede envolvida com a utilização desses insumos.

Esse processo de institucionalização do receituário agronômico foi sendo construído pela rede de atores formada pela corporação agronômica (através das associações e conselhos profissionais, sindicatos, e pelos próprios técnicos atuantes), pelos representantes da indústria química, os comerciantes, os agricultores, os pesquisadores, as escolas de agronomia, os serviços de extensão rural, dentre outros.

A idéia de incorporar ao conteúdo do receituário os tópicos relativos ao manejo integrado de pragas, precauções de uso, primeiros socorros nos casos de acidentes, advertências relacionadas ao meio ambiente, conforme estabelecido na legislação, guardaria alguma relação com as intenções colocadas nas discussões iniciais da adoção desta prática; entretanto o reducionismo incorporado ao exercício do receituário agronômico consegue apenas imprimir, no verso dos formulários de receita, informações padronizadas sobre os cuidados com a saúde e com o ambiente.

Neste patamar de burocratização o exercício técnico passa a ser totalmente desprovido de criatividade ou compromisso com as conseqüências das recomendações formuladas, restando sempre a possibilidade da simples cópia das indicações técnicas apresentadas nas bulas dos agrotóxicos, ou ainda a prescrição do "vide verso", remetendo o poder do discernimento técnico ao padrão comum da letra previamente impressa nos formulários de receitas.

Cerca de dez anos após o estabelecimento generalizado da prática legal do receituário no país, são suscitadas algumas questões intrigantes, surgidas na dinâmica das relações construídas em torno desse instrumento, tais como:

1. Quais fatores motivaram um grupo seleto de agrônomos e ambientalistas, envolvidos na luta pelo controle do uso indiscriminado dos agrotóxicos, a propor ao final da década de 70 a institucionalização do receituário agronômico? 
2. Que tipo de visão alimentava a concepção de seus proponentes no sentido de tornar a prática do receituário agronômico algo além da criação de um mecanismo de controle de vendas de insumos?

3. Como se posicionam os representantes dos diversos setores que participam dos processos de desenvolvimento e de adoção da tecnologia dos agrotóxicos em relação à eficácia do receituário como instrumento de controle do uso indiscriminado de agrotóxicos?

4. Caracterizada sua ineficiência e ineficácia como instrumento de gestão dos agrotóxicos, como explicar a permanência desse instituto no sistema?

Esta dissertação apóia-se nas seguintes hipóteses de pesquisa:

1. A prática do receituário agronômico, exercitada após a implantação da lei dos agrotóxicos, se resume a um mero ritual burocrático sem eficácia como forma de controle do uso dos agrotóxicos. De certa forma os princípios inicialmente concebidos para a prática do receituário foram "traídos", ao longo do processo de sua implantação. O receituário agronômico implantado após a lei dos agrotóxicos descaracteriza a atuação do agrônomo como organizador do processo produtivo na agricultura, em especial no tocante à proteção vegetal, reduzindo sua ação ao papel de simples indutor da adoção da tecnologia química.

2. Os atores dos meios agronômicos que propuseram a idéia do receituário agronômico (extensionistas, ambientalistas, pesquisadores, técnicos, consultores, associações e conselhos profissionais - CREA's-, etc) incorreram em um erro de concepção ao vislumbrarem a possibilidade de transferência do modelo de relação estabelecida entre "médico-paciente-medicamento" para a rede que agrega "técnicos-produtores rurais-agrotóxicos". 
3. O receituário agronômico na forma como é hoje aplicado não resulta em qualquer contribuição eficaz para o manejo dos problemas decorrentes do uso de agrotóxicos. Sua manutenção nestas bases atende apenas a interesses de parcelas da corporação e das instituições agronômicas que se beneficiam de seu ritual operacional. A ausência atual de oposição da indústria de agrotóxicos em relação ao receituário agronômico pode ser explicada, além de outros fatores, pela própria inocuidade deste instituto como instrumento de controle.

Para expor as evidências que corroboram estas hipóteses, o texto apresenta, inicialmente, um panorama geral sobre o uso de agrotóxicos no Brasil (e sua inserção em relação aos demais países). Em seguida investiga e discuti os fatores de origem da adoção do receituário agronômico, a partir do desenho de um quadro histórico do processo de proposição e adoção desse instituto. Na terceira parte deste estudo dedicase a atenção à visão atual dos principais atores envolvidos com o receituário, no quadro de seu atual contexto de aplicação e aplicabilidade.

Por fim, após a discussão dos problemas formulados busca-se a conclusão da pesquisa, com algumas proposições sobre estratégias de controle dos agrotóxicos.

A abordagem pretendida neste estudo está focalizada na idéia de que o desenvolvimento e a aplicação de determinada tecnologia caracteriza-se como um processo de construção social influenciado por fatores ligados aos diferentes atores envolvidos, e também pela própria ação dos processos e artefatos tecnológicos construídos, na medida em que estes também influenciam o relacionamento entre os envolvidos.

Tal abordagem inspira-se nas correntes de investigação em filosofia e sociologia da ciência e da tecnologia surgidas a partir da segunda guerra mundial, denominadas estudos sobre ciência, tecnologia e sociedade, que agregam um novo enfoque neste campo na medida em que se dedicam ao estudo dos aspectos sociais do fenômeno científico e tecnológico, tanto no tocante aos condicionantes de seu desenvolvimento como no que se refere às suas conseqüências sociais ou ambientais. 
Os estudos recentes sobre sociologia do conhecimento científico tomam como objeto de estudo o conteúdo atual das idéias científicas, os experimentos, as teorias; isto tudo em contraste com os trabalhos iniciais da sociologia da ciência que se dedicavam a abordar a ciência como uma instituição e elegiam seus objetos de interesse focados nas normas científicas, nos padrões de carreiras científicas e nas estruturas de recompensas. A partir da visão do programa forte proposto por David Bloor o conhecimento passa a ser entendido como uma construção social:

"...seu princípio central é que ao se investigar as causas das crenças os sociólogos devem ser imparciais com o que se acredita como verdadeiro e a falso; tais crenças devem ser explicadas simetricamente" (BLOOR, 1973 apud PINCH \& BIJKER, 1989:18).

As explanações sobre a gênese, aceitação e a rejeição das afirmações de conhecimento são buscadas nos domínios do mundo social, em lugar de pesquisas no mundo natural (PINCH \& BIJKER, 1989).

Tomando-se como base os princípios gerais preconizados por David Bloor várias linhas metodológicas surgem dentro do perfil de abordagem do construtivismo social, de onde se pode destacar:

- os estudos etnográficos e de laboratórios: autores como KNORR-CETINA (1983), LATOUR \& WOOLGAR (1979) e LAW (1986). O produto da ciência é fabricado, construído e negociado por atores específicos em determinado tempo e local, não sendo gerado a partir de uma racionalidade científica especial que seja neutra ou fora do alcance de interesses. A ciência é caracterizada como uma atividade que inventa uma ordem e não um dispositivo que revela a ordem escondida do mundo natural ou social. Portanto seus enunciados devem ser contextualizados; 
- os estudos e análises sobre controvérsias: focalizados em estudos empíricos dos desenvolvimentos científicos, analisando-se em particular as controvérsias, como mecanismos através dos quais se negociam os consensos.

"Collins indica o caminho: cumpre estudar a ciência atual, a que está sendo feita, em meio a toda a controvérsia, de modo a sair definitivamente do conforto intelectual dos historiadores que estão sempre chegando atrasados. Em lugar de estudar as ciências 'sancionadas', cabe estudar as ciências abertas e incertas"(LATOUR \& WOOLGAR, 1997:21).

Dentre as várias abordagens metodológicas propostas para os estudos com enfoque social construtivista PINCH \& BIJKER (1989) indicam a possibilidade de uma abordagem integrada para os estudos empíricos sobre ciência e tecnologia. Ao traçar um paralelo entre as propostas do programa empírico do relativismo (sigla EPOR) proposto por COLLINS (1981) utilizado no campo da sociologia do conhecimento científico e o enfoque do social construtivismo (sigla SCOT) apresentado por Bijker e Pinch, com aplicações no campo da sociologia da tecnologia, os autores indicam a similaridade das metas explanatórias presentes nas duas abordagens. Os conceitos de flexibilidade interpretativa, os mecanismos de encerramento das controvérsias e a noção de grupos sociais relevantes estão presentes nas duas abordagens e podem dar referência empírica aos estudos sociais da tecnologia.

PINCH \& BIJKER (1989) sustentam que ciência e tecnologia são culturas socialmente construídas e que suas fronteiras são matérias de negociação e representam distinções não fundamentais. HUGHES (1989) afirma que os rótulos ciência e tecnologia são imprecisos e não transportam a desarrumada complexidade das entidades definidas; ademais Hughes identifica alguns cientistas desenvolvendo tecnologias, uma função normalmente associada a engenheiros, e alguns engenheiros como que fazendo pesquisas de formas normalmente associadas a cientistas. Para ele, entusiásticos solucionadores de problemas e dedicados construtores de sistemas não respeitam fronteiras disciplinares ou de conhecimento. 
Para CALLON (1989), a questão sobre quem é o cientista e quem é o tecnologista é negociável de acordo com as circunstâncias. Ele acredita que "a rede não tem emendas", e questiona porque alguém deve categorizar elementos de um sistema ou rede "quando estes estão permanentemente interagindo, associando-se, e sendo testados pelos atores que inovam". Ele define "atores" como as entidades heterogêneas que constituem a rede, e incluem: elétrons, catalisadores, acumuladores, usuários, pesquisadores, fabricantes, e departamentos ministeriais definindo e estabelecendo regulamentos afetando a tecnologia.

Conforme observam BIJKER \& PINCH (1989), o termo tecnologia pode ser enganoso e conceitos como "mudança tecnológica" e "desenvolvimento tecnológico" geralmente carregam uma pesada carga interpretativa.

Ao menos três significados para a palavra "tecnologia" podem ser distinguidos: em primeiro lugar há o nível dos artefatos ou objetos fisicos, em segundo lugar "tecnologia" pode se referir a atividades e processos, e em terceiro lugar o termo pode estar ainda relacionado ao que as pessoas conhecem, bem como ao que fazem (knowhow). A separação destes três significados nem sempre é possível, e na prática a tecnologia se distribui nestas três direções, cobrindo todos os aspectos (MACKENZIE \& WAJCAMAN, 1985, apud: BIJKER, HUGHES \& Pinch, 1989).

Pretendemos abordar o receituário agronômico como atividade, processo, um código institucional de acesso intermediando a relação entre os agricultores e a tecnologia dos agrotóxicos. Embora ele não se caracterize propriamente como uma tecnologia, na visão da sociologia das ciências e das técnicas ele pertence a uma rede sócio-técnica.

Winner em sua avaliação sobre o caráter político das tecnologias observa:

" O que denominamos como 'tecnologias' são os modos de ordenar nosso mundo. Muitas invenções e sistemas técnicos importantes em nossa vida cotidiana trazem a possibilidade de organizar a atividade humana de diversas maneiras. 
Conscientemente ou não, deliberada ou inadvertidamente, as sociedades elegem estruturas para as tecnologias que influenciam sobre como as pessoas vão trabalhar, como se comunicam, como viajam, como consomem...ao largo de toda sua vida " (WINNER, 1983:4).

A interação desses atores ocorre numa rede de trabalho para criar um mundo coerente, sem distinção entre o animado e o inanimado, os indivíduos e as instituições. Em sua abordagem CALLON (1989) afirma que o mundo dos atores modela e suporta o objeto técnico. Não há dicotomia entre o interno e o externo, entre o social e o tecnológico.

PINCH \& BIJKER (1989), enfatizam a modelagem social na definição das características técnicas de um artefato. Eles argumentam que grupos sociais cumprem um papel crítico na definição e resolução dos problemas que surgem durante o desenvolvimento de um artefato. Para estes autores a controvérsia sobre a verdade ou a falsidade das crenças, ou sobre o sucesso ou fracasso de uma tecnologia na resolução de problemas pode constituir-se em objeto de pesquisa recomendável.

Os três estágios explanatórios propostos por PINCH \& BIJKER (1989) em suas trajetórias de análise irão compor a base do presente estudo, a saber:

1. Dar visibilidade à flexibilidade interpretativa do artefato tecnológico. A tecnologia dos agrotóxicos é resultado de uma construção cultural, assim pode ser interpretada, e nesse contexto a institucionalização do receituário agronômico reflete a controvérsia presente nesse processo de construção ;

2. Mapear os mecanismos de encerramento dos debates e controvérsias que envolvem a estabilização do artefato tecnológico. Identificar os mecanismos que fazem com que os grupos sociais relevantes na questão dos agrotóxicos venham a considerar o problema ou a controvérsia "encerrada", a partir da adoção, dentre outros mecanismos, do receituário 
agronômico como forma de controle institucional do uso da tecnologia química.

3. Relacionar o conteúdo do artefato tecnológico a uma leitura sócio-política mais ampla. Explorar o processo de construção do receituário agronômico relacionando-o ao contexto mais amplo do processo de modernização da agricultura, às mudanças ocorridas no perfil das relações entre extensionistas e agricultores, e às questões ambientais e de saúde pública decorrentes do uso de agrotóxicos.

Os impactos sociais, ambientais e econômicos decorrentes do uso de agrotóxicos na atividade agrícola são bastante conhecidos e o perfil das formas de disponibilidade, acesso e utilização destes insumos no processo produtivo repercutem diretamente sobre os vários interesses presentes nessa rede.

Desta forma, a construção do receituário agronômico se caracteriza como uma tentativa de criação de uma instituição para intermediar o acesso dos agricultores às formas de controle dos problemas de pragas e doenças na atividade agrícola, em especial através do uso de agrotóxicos e, por conseqüência, contribui fortemente para o estabelecimento das relações desenhadas em toda a cadeia envolvendo os produtores rurais, os técnicos, a indústria química, a comunidade de pesquisadores científicos, os consumidores de produtos agrícolas, os ambientalistas, a corporação agronômica, os legisladores, as agências de financiamento, os órgãos públicos ligados à fiscalização nas áreas de saúde, ambiente, agricultura e trabalho, dentre outros. Ainda segundo WINNER (1983):

" Nos processos mediante os quais se tomam decisões sobre estas estruturas, as pessoas terminam distribuindo-se em diferentes estratos de poder e em diferentes níveis de conhecimento, por mais liberdade de escolha que exista quando se introduzem pela primeira vez instrumentos, técnicas ou sistemas particulares. Devido ao fato de que as escolhas sobre os equipamentos materiais, os investimentos de capitais e os hábitos sociais tendem muito rapidamente a estabilizar-se, a primitiva 
flexibilidade relacionada aos propósitos práticos desaparece uma vez que se adotam certos compromissos iniciais. Neste sentido, as inovações tecnológicas se assemelham aos decretos legislativos, ou às fundamentações políticas que estabelecem um marco para a ordem pública que se perpetuará através de gerações" (WINNER, 1983:4-5).

$\mathrm{Na}$ visão do social construtivismo colocada por BIJKER, HUGHES \& PINCH (1989), sustenta-se a idéia de que os artefatos tecnológicos são abertos a análises sociológicas, não apenas em seus usos, mas especialmente com respeito aos seus desenhos e conteúdos técnicos. A forma como o receituário agronômico é definido e praticado, tanto em sua concepção inicial como na atual, reflete diretamente no desenho da relação entre técnicos e agricultores, agricultores e agrotóxicos, e todas as demais ligações passíveis de serem identificadas na rede de atores relevantes para o estudo. Este aspecto motiva a escolha do receituário como objeto de estudo, ou ainda como ponto de partida para dar visibilidade às relações e aos interesses que giram em torno dos agrotóxicos, a exemplo do sugerido por Winner:

" Por esta razão deveríamos conceder à construção das rodovias, às criações de redes de televisão e à introdução de características aparentemente insignificantes às novas máquinas, a mesma cuidadosa atenção dada às regras, aos papéis e às relações na política. Estes elementos que unem ou dividem as pessoas dentro de uma sociedade em particular não se constroem somente por meio das instituições e prática políticas, mas também, e de maneira menos evidente, por meio de projetos tangíveis de aço e concreto, cabos e transistores, porcas e parafusos" (WINNER, 1983:5).

O tratamento da tecnologia em termos de metáforas de "sistemas", por sua vez, ressalta a importância de atuação nos diferentes e inter-relacionados elementos dos artefatos físicos, das instituições e de seus ambientes; oferecendo desse modo uma integração dos aspectos técnicos, sociais e políticos. Conceitos como "problemas críticos" definem a parte do sistema onde em certos estágios energias inovativas são focalizadas, habilitando-nos a fazer a ligação entre os níveis micro e macro de análises - “ligar o laboratório de Edson à sociedade como um todo”(HUGHES, 1989); o que no caso do receituário agronômico constituiria por exemplo a ligação do escritório de 
extensão rural ou de consultoria agronômica aos agricultores e seus problemas de proteção de plantas. Estas ligações não podem ser entendidas como genéricas, nem podem ser deduzidas de toda e qualquer situação onde se dá o uso de agrotóxicos. $\mathrm{Na}$ verdade, a forma de controle social do uso de determinada tecnologia é particular de cada sociedade.

Finalmente a quebra da distinção entre atores humanos e o fenômeno natural tenta estender essa perspectiva a um novo degrau onde ambos são tratados como elementos de uma "rede de atores". Conforme ressaltam Bijker, Hughes \& Pinch, esta abordagem reverte ostensivamente as relações usuais entre participantes e analistas, atribuindo aos engenheiros o papel de sociólogos; ou seja:

"na tentativa de estender com sucesso a rede de atores, os engenheiros tentam moldar a sociedade" (CALLON, 1989). 


\section{UMA VISÃO GERAL SOBRE OS AGROTÓXICOS}

\section{1. Um breve histórico}

A utilização de substâncias químicas como forma de controle ou eliminação dos problemas decorrentes dos ataques de pragas e doenças nas plantas cultivadas e nos animais de criação pode ser identificada em registros que remontam a Antigüidade Clássica.

Escrituras gregas e romanas de mais de 3000 anos já mencionavam o uso de produtos químicos como o arsênico, utilizado para o controle de insetos. Compostos orgânicos naturais como a piretrina, obtida das flores de crisântemos (Chrysanthemum $s p$ ) eram utilizados como inseticidas pelos Chineses a cerca de 2000 anos atrás. Povos do deserto protegiam suas tendas de armazenamento de cereais acrescentando pó de piretro sobre os grãos, ou pendurando feixes dessas flores na entrada das tendas, servindo ainda como repelentes de moscas e mosquitos (PASCHOAL, 1979; MILLER Jr., 1990; GUERRA \& SAMPAIO, 1991; YULDEMAN et al., 1998 ).

Outros compostos orgânicos vegetais, como a nicotina derivada do tabaco, e a rotenona extraída de raízes do timbó (Derris sp), já eram há muito conhecidos por suas propriedades inseticidas. 
Em relação aos compostos inorgânicos a base de metais tóxicos, tais como: cobre, enxofre, e mercúrio; estes foram largamente empregados na Europa do século 19 para

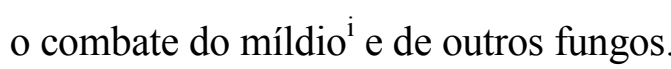

Há registros de que o uso do verde-paris (acetoarsenito de cobre) no controle de um coleóptero (Leptinotarsa dcemlineata Say) na cultura da batatinha foi verificado pela primeira vez nos Estados Unidos, em 1867. Já em 1885 descobria-se a ação fungicida do sulfato de cobre, amplamente divulgada a partir da utilização da preparação conhecida como "calda bordalesa".

O uso do cloreto de mercúrio como bactericida no tratamento de sementes foi registrado pela primeira vez em 1890. Assim, ao final do século IX e nas três primeiras décadas do século XX ocorre um grande avanço no uso de produtos químicos para a proteção de plantas contra pragas e doenças, produtos estes basicamente constituídos por compostos inorgânicos à base de flúor, arsênico, mercúrio, selênio, chumbo, bórax, sais de cobre e zinco, os quais vieram a compor a chamada "primeira geração" de agrotóxicos (GUERRA \& SAMPAIO, 1991).

A maioria destes produtos da primeira geração, a base de metais tóxicos, não é mais utilizada tendo em vista suas características de alta toxicidade para humanos e animais e elevada persistência no ambiente. Tais produtos podem contaminar os solos por mais de 100 anos, e ainda se acumular a ponto de inibir o crescimento das plantas.Traços de alguns desses compostos tóxicos persistentes ainda são encontrados em verduras, folhas de fumo e outros vegetais cultivados em solos que há décadas receberam doses pesadas desses agrotóxicos (MILLER Jr., 1990).

O primeiro produto inseticida desenvolvido por síntese orgânica, a base de tiocianato, foi comercializado com o nome de Lethane 384, no ano de 1932, inaugurando assim a chamada "segunda geração" de agrotóxicos (GUERRA \& SAMPAIO, 1991).

\footnotetext{
${ }^{\mathrm{i}}$ Uma das doenças parasitárias mais comuns que atacam especialmente as hortaliças, tais como: tomate, berinjela, batatinha, espinafre, feijoeiro, cebola e nabo. Tem como agente etiológico os fungos Peronospora spp., Phytophthora spp. ou Plamopara spp.
} 
Todavia é a partir da Segunda Guerra Mundial, com o desenvolvimento da indústria de síntese química, que ocorre a difusão e a larga e progressiva utilização de biocidas sintetizados.

Em 1939, com a descoberta das propriedades inseticidas do DDT (Dicloro Difenil Tricloroetano), um composto orgânico sintetizado por Otto Ziedler em 1874, foi dado início a um marco revolucionário nas tecnologias até então empregadas para o combate às pragas. A relevância desse desenvolvimento, que desencadeou mudanças importantes no campo da agricultura e da saúde pública, levou seu responsável, o pesquisador Paul Muller, da companhia suíça Geigy, a ser contemplado com o Prêmio Nobel de fisiologia e medicina, do ano de 1948 (PASCHOAL, 1979).

As propriedades inseticidas do BHC (Hexaclorociclohexano) foram descobertas quase que simultaneamente, a partir de estudos realizados por pesquisadores franceses e ingleses nos anos de 1941-42.

Durante o período da Segunda Guerra Mundial vários produtos biocidas foram desenvolvidos pela indústria química alemã e americana. Entre os gases de guerra produzidos pela indústria alemã, estavam alguns derivados do ácido fosfórico, os quais posteriormente deram origem aos inseticidas do grupo do parathion. Os técnicos da indústria química de guerra americana trabalharam intensamente no desenvolvimento de substâncias que pudessem ser aplicadas na destruição, por via aérea, das áreas de colheitas dos inimigos.

"...quando a primeira bomba atômica explodiu, no verão de 1945, viajava em direção ao Japão um barco americano com uma carga de fitocidas, então declarados como LN 8 LN 14, suficientes para destruir 30\% das colheitas. Com a explosão das bombas o Japão capitulou, o barco voltou. Mais tarde, na Guerra do Vietnam, estes mesmos venenos, com outros nomes, tais como "agente laranja" e agentes de outras cores, serviram para destruição de dezenas de milhares de quilômetros quadrados de florestas e de colheitas (...) os químicos que conceberam aquela forma de guerra química passaram a oferecer à agricultura seus venenos, agora chamados de 
herbicidas, do grupo do ácido fenoxiacético, o 2,4-D e o 2,4,5-T MCPA e outros" (LUTZEMBERGER, 1992:98-99).

Desde então uma grande variedade de produtos sintéticos é desenvolvida pela indústria química mundial, resultando em milhares de formulações comerciais difundidas no mercado internacional de insumos para a agricultura.

No Brasil, os primeiros registros de compostos organoclorados foram feitos no ano 1946. Nesse mesmo período foram introduzidos os inseticidas sistêmicos e, em 1958, os antibióticos à base de sais de estreptomicina. Durante os anos de 1954 a 1960, foi intenso o processo de registro de novos produtos junto ao ministério da agricultura. Os números divulgados pelo serviço de defesa sanitária vegetal davam conta de que 2.045 produtos haviam sido registrados no período (LIMA, 1960:62).

Ao final dos anos 50 e início dos 60 surgem os primeiros processos de reavaliação dos problemas de segurança e eficácia dos agrotóxicos, na comunidade técnica internacional. A visão dos problemas decorrentes do uso generalizado de substâncias químicas para o combate às pragas, em especial do DDT, foi em grande parte influenciada pelas denúncias que culminaram com a publicação do livro da pesquisadora americana Rachel Carson, denominado Silient Spring, no ano de 1962. As teses sustentadas pelo livro ressaltavam os riscos crescentes envolvidos na manutenção dos padrões de uso dos agrotóxicos e a necessidade urgente de mudanças em busca de práticas alternativas de menor impacto ao ambiente e à saúde humana.

Não obstante a forte reação da indústria química em relação ao trabalho de Carson, os argumentos consistentes apresentados pela pesquisadora influenciaram fortemente a opinião pública americana, desencadeando um processo de reavaliação dos agrotóxicos pelos órgãos governamentais daquele país, em processo que culminou com a criação da agência ambiental americana (Environmental Protection Agency - EPA ), e posteriormente, com o banimento do uso agrícola de produtos organoclorados. (NRC,2000). A partir de 1971 vários produtos sintéticos são banidos ou mantidos sob 
uso restrito, pelo órgão ambiental americano, por conta da constatação dos efeitos nocivos à saúde e ao ambiente (Tabela 1).

Tabela 1 - Ações regulatórias da EPA e situação especial de revisão de agrotóxicos usados na produção agrícola.

\begin{tabular}{|c|c|c|}
\hline Ano & Produto & Ação regulatória \\
\hline 1972 & Aldrin & Todos os usos cancelados, com exceção do controle de cupins. \\
\hline 1972 & DDT & $\begin{array}{l}\text { Todos os usos cancelados (exceto para controle de vetores em saúde } \\
\text { pública). }\end{array}$ \\
\hline 1981 & Dimethoate & Proibição da formulação em pó. Mudanças na rotulagem. \\
\hline 1982 & EBDC & $\begin{array}{l}\text { Advertências quanto ao uso de vestimentas de proteção e aos riscos à } \\
\text { vida silvestre. }\end{array}$ \\
\hline 1982 & Toxaphene & $\begin{array}{l}\text { Cancelamento da maioria das autorizações de uso, com exceção de } \\
\text { algumas situações emergenciais de infestações de insetos nas culturas de } \\
\text { milho, algodão e outros grãos. }\end{array}$ \\
\hline 1982 & Trifluralin & Restrições sobre a formulação de produtos. \\
\hline 1985 & Endrin & Todos os usos cancelados. \\
\hline 1985 & Ethalfluralin & Riscos excedendo os benefícios; exigências de novos dados. \\
\hline 1987 & Alaclor & $\begin{array}{l}\text { Uso restrito e rotulagem de advertência, em função de problemas } \\
\text { decorrentes da contaminação de águas subterrâneas. }\end{array}$ \\
\hline 1987 & Captafol & Todos os usos cancelados. \\
\hline 1988 & Chlordimeform & Todos os usos cancelados, uso dos estoques existentes até 1989. \\
\hline 1988 & Heptaclor & Todos os usos cancelados, exceto para o controle de cupins. \\
\hline 1988 & Monocrotophos & Todos os usos cancelados. \\
\hline 1989 & Dinoseb & Todos os usos cancelados. \\
\hline 1989 & Linuron & Revisão efetuada. Nenhuma ação regulatória adicional. \\
\hline 1990 & Diazinon & Todos os usos em campos de golf e gramados cancelados. \\
\hline 1991 & Parathion & $\begin{array}{l}\text { Uso restrito a culturas de campo. Sob revisão com exigências de dados } \\
\text { toxicológicos. }\end{array}$ \\
\hline 1992 & Aldicar & Uso cancelado para a cultura da banana. Colocado sob risco alimentar. \\
\hline 1992 & $2,4-\mathrm{D}$ & $\begin{array}{l}\text { Concordância da indústria em reduzir a exposição através de mudanças } \\
\text { nos rótulos e educação dos usuários. }\end{array}$ \\
\hline 1993 & Methyl bromide & $\begin{array}{l}\text { Produção anual e uso limitado aos níveis praticados em 1991, com } \\
\text { previsão de banimento em } 2001 .\end{array}$ \\
\hline 1994 & Mevinphos & Cancelamento voluntário de todos os usos \\
\hline 1995 & Cyanazine & $\begin{array}{l}\text { Diminuição voluntária da produção até 2000, com utilização dos } \\
\text { estoques até } 2003\end{array}$ \\
\hline 1996 & Propargite & Cancelamento do registro de uso para 10 culturas \\
\hline
\end{tabular}


Já na década de 60 começam a surgir novos produtos classificados como de "terceira geração", em uma fase onde a busca por produtos menos tóxicos para o homem e o ambiente passa a ocupar a estratégia da indústria química. Tal reação se dá em função dos graves problemas identificados, tanto em relação aos processos de intoxicações agudas e crônicas sofridos pelas populações expostas direta e indiretamente, como pelos acidentes ambientais e problemas de eficiência agronômica dos produtos, estes últimos desencadeados pelos mecanismos de resistência das populações de pragas aos produtos até então em uso.

Fazem parte desta terceira geração de agrotóxicos as formulações à base de semioquímicos (ferormônios), os fisiológicos (diflubenzuron), os biológicos (Bacillus thuringiensis) e também os piretróides (GUERRA \& SAMPAIO, 1991).

Os avanços nos estudos entomológicos, sobretudo em relação ao campo da fisiologia dos insetos, permitiram o desenvolvimento de produtos com modos de ação sofisticados, que atuam no sistema endócrino, interferindo sobre hormônios que regulam o crescimento dos insetos, tais como o methoprene, um composto que funciona de forma análoga a um hormônio juvenil, de forma a interferir no processo de maturação dos insetos.

Os produtos derivados destas tecnologias, identificados com pertencentes à quarta geração de agrotóxicos, apresentam algumas vantagens comparativas com os demais, tais como: especificidade de ação e alta capacidade de degradação ambiental (NRC, 2000); não obstante as preocupações crescentes quanto às implicações de médio e longo prazo à saúde humana, decorrentes das exposições ocupacionais e ambientais a estes produtos.

A utilização de substâncias químicas para o combate das pragas e doenças que afetam a atividade agropecuária e florestal, a partir do desenvolvimento dos produtos sintéticos e da ampla divulgação dessa tecnologia em todo os países, sempre motivou um caloroso debate sobre os reais prejuízos e benefícios advindos dos pesticidas. MILLER Jr.(1990) apresenta um quadro geral desse debate (Figura 1). 


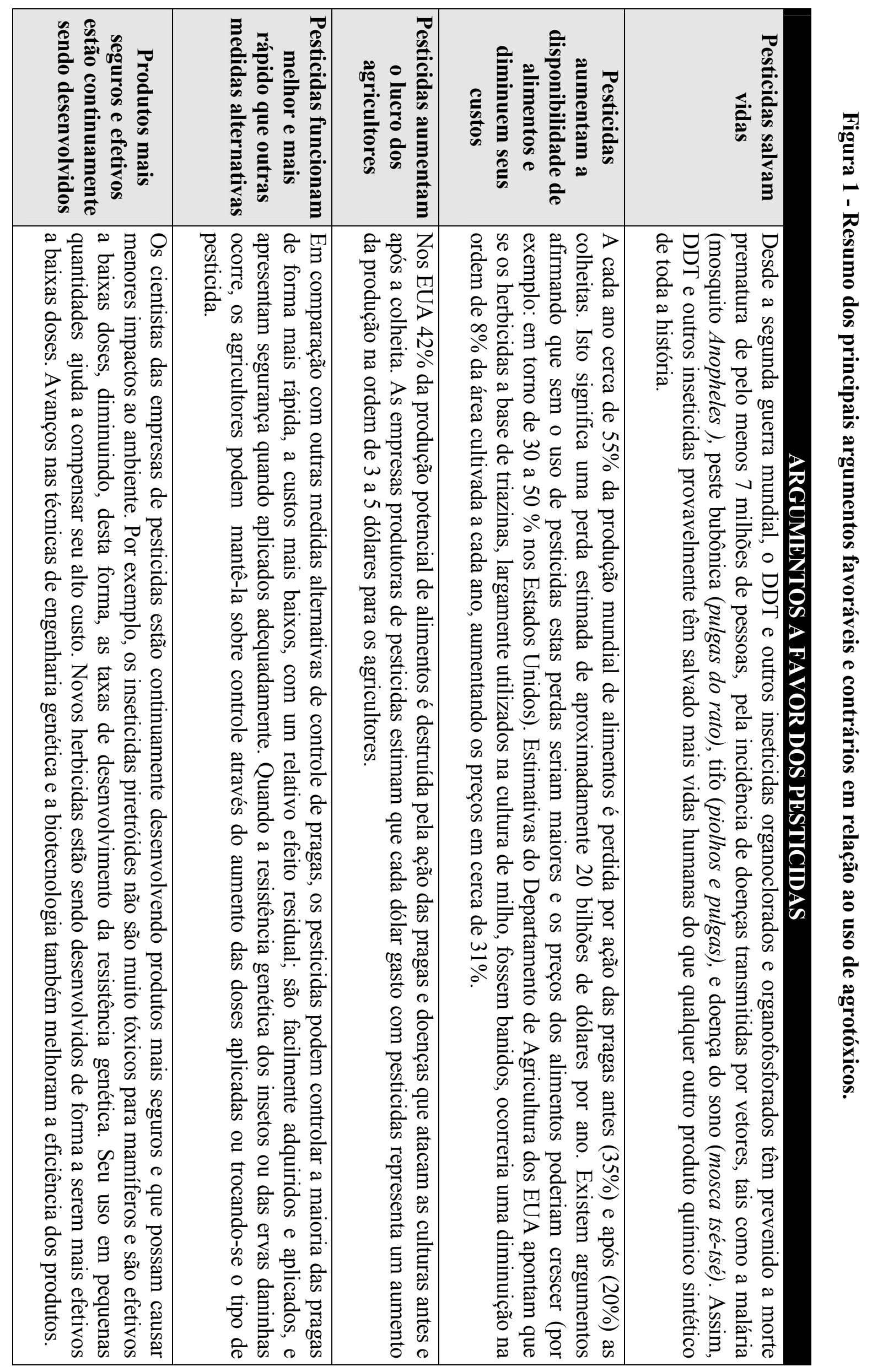




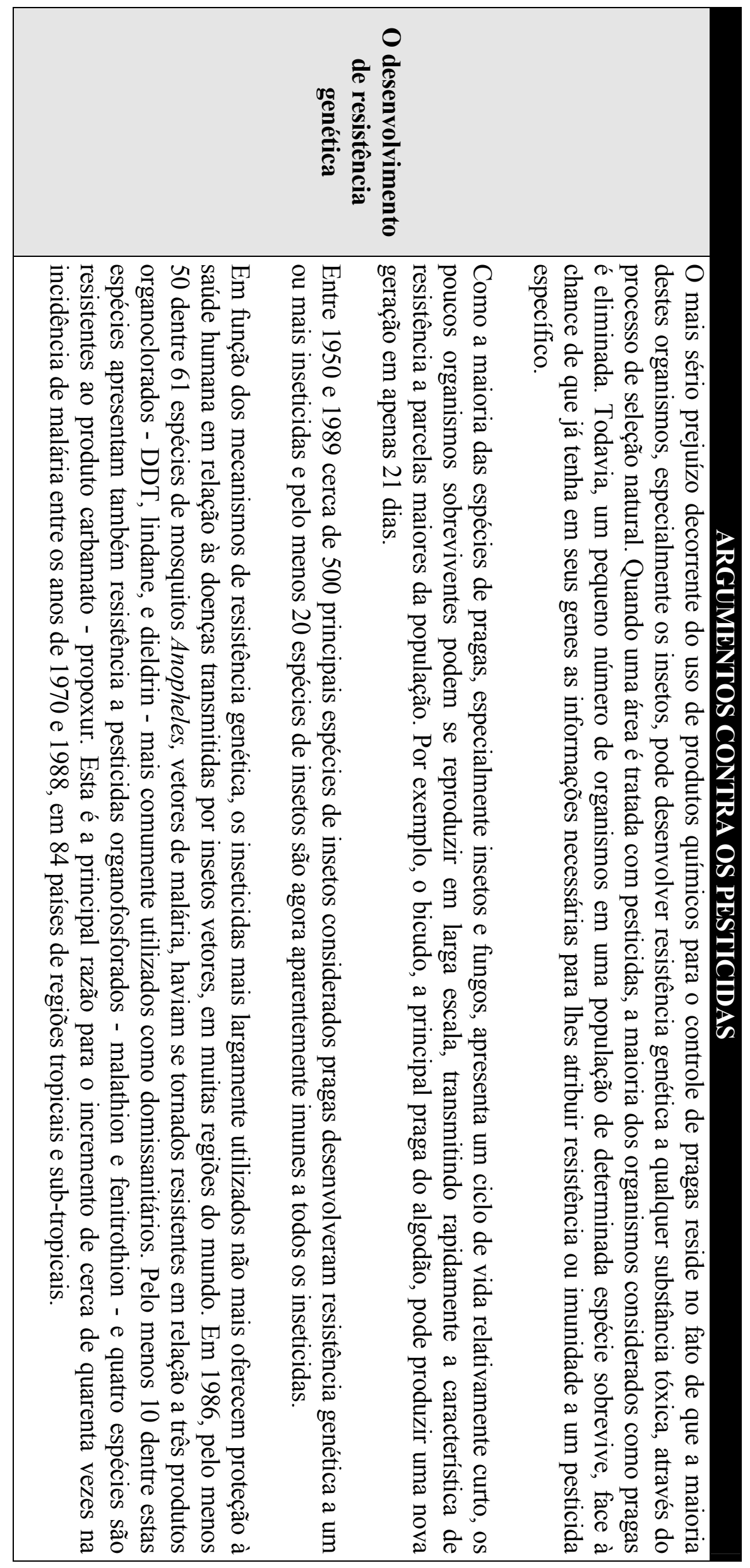




\begin{tabular}{|c|c|c|c|}
\hline & 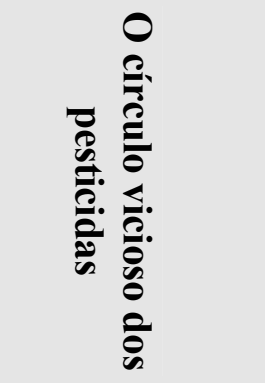 & & 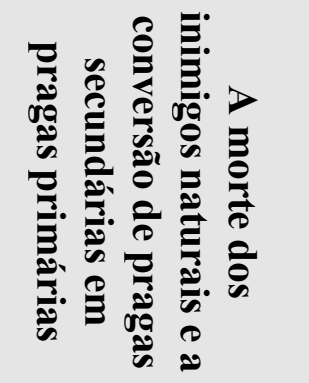 \\
\hline 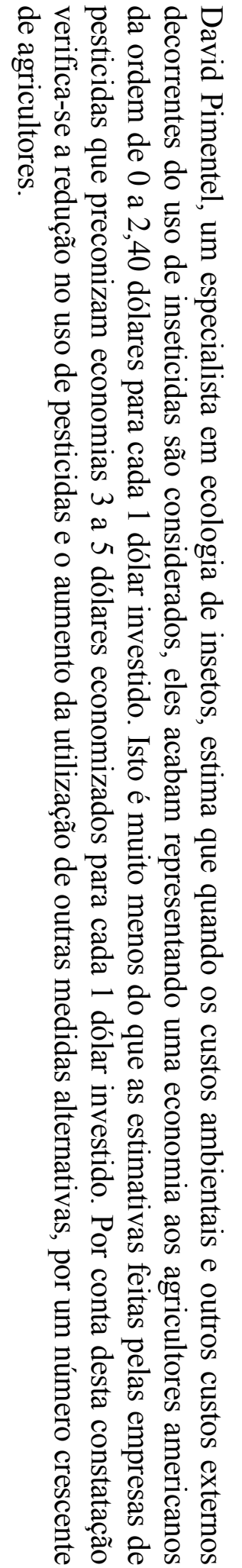 & 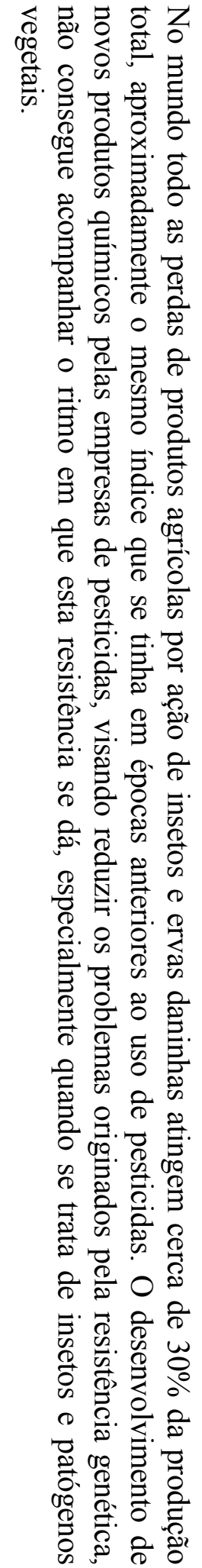 & 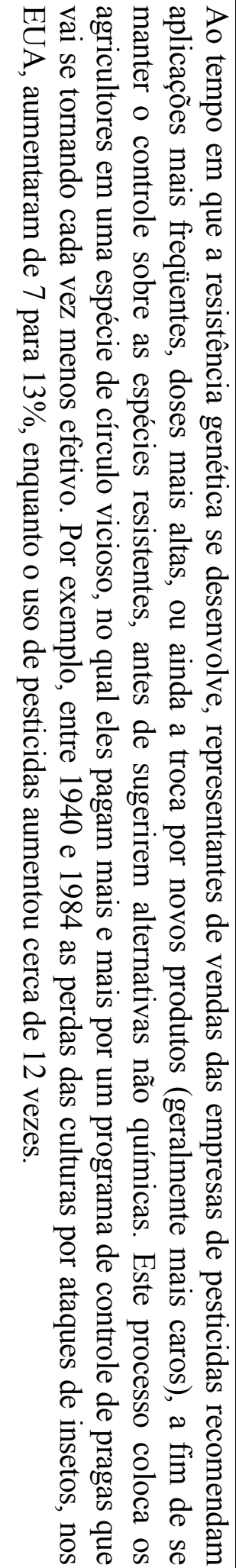 & 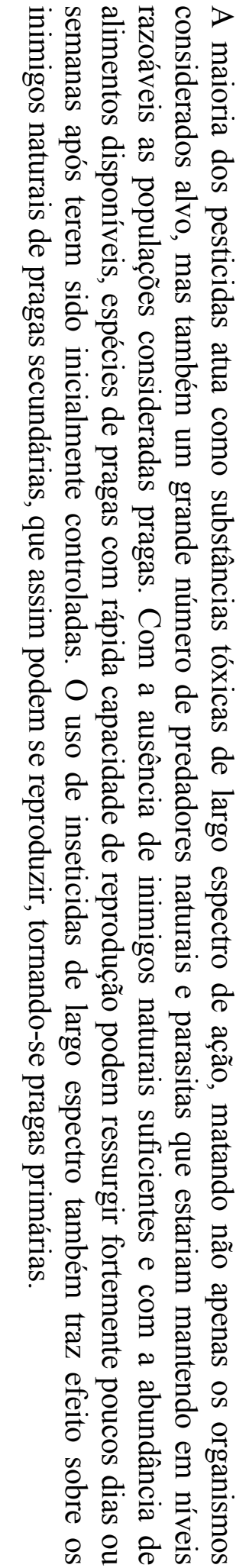 \\
\hline
\end{tabular}




\begin{tabular}{|c|c|c|c|c|}
\hline \multicolumn{2}{|c|}{ 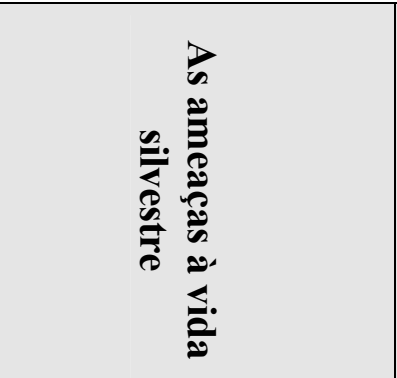 } & \multicolumn{3}{|c|}{ 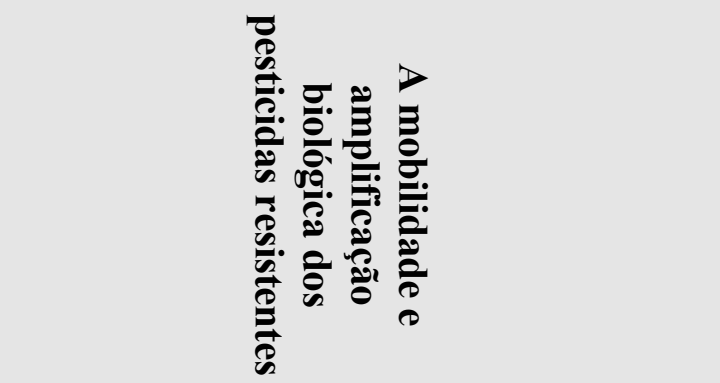 } \\
\hline 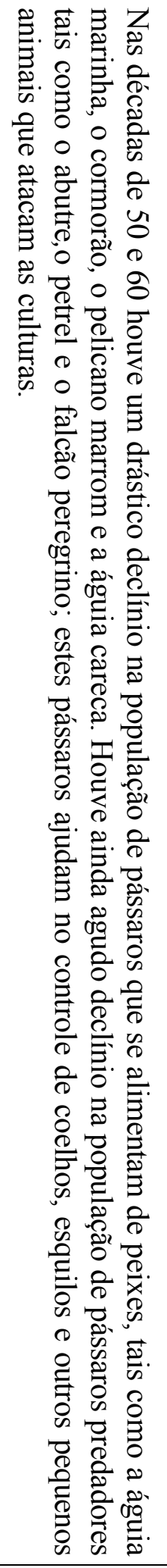 & 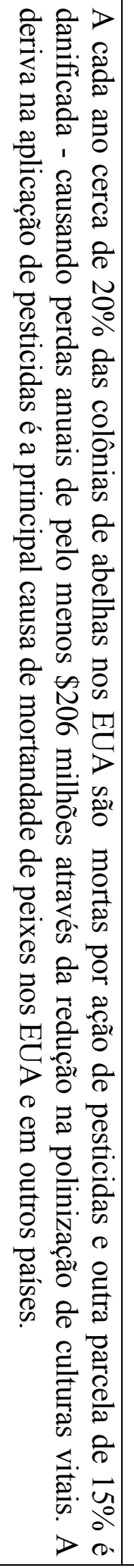 & 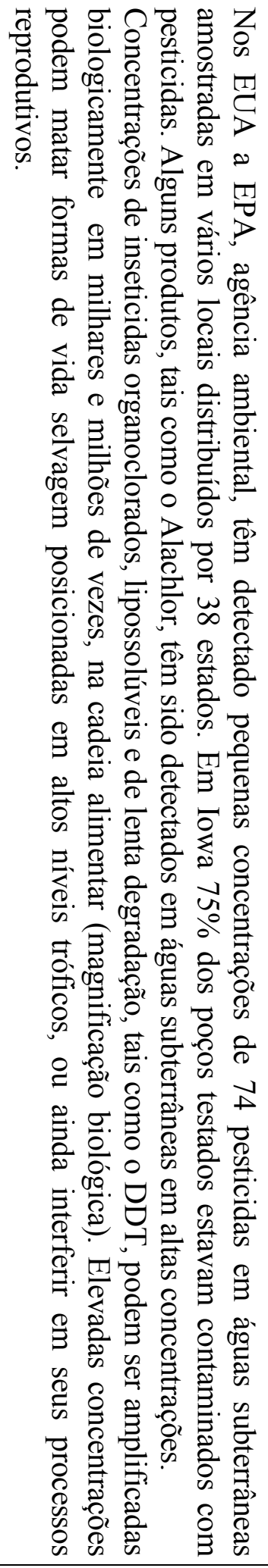 & 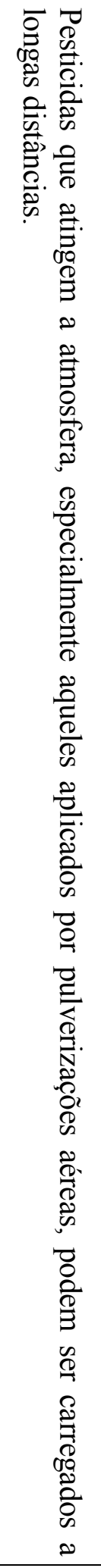 & 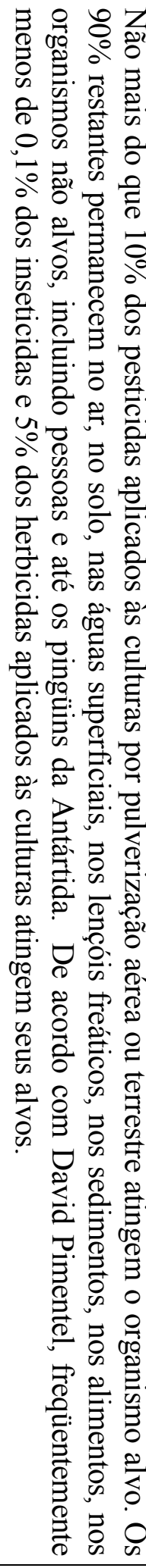 \\
\hline
\end{tabular}




\begin{tabular}{|c|c|c|c|c|}
\hline \multicolumn{5}{|c|}{ 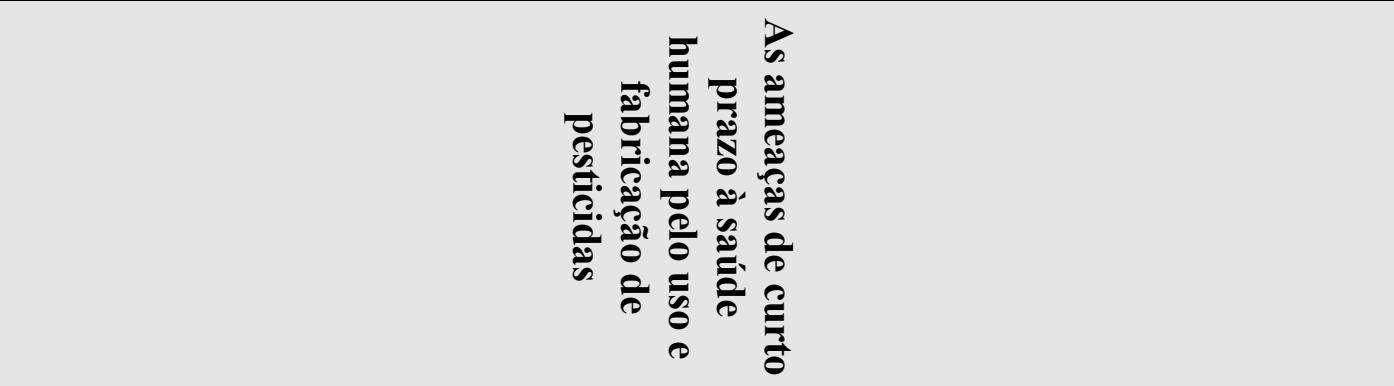 } \\
\hline 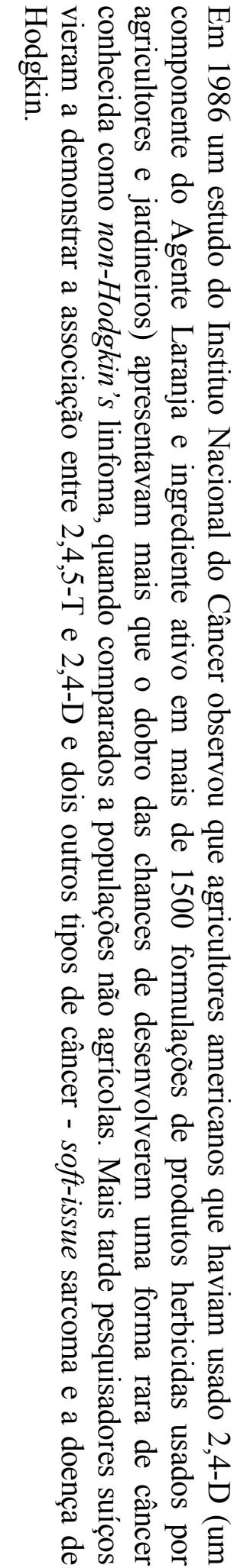 & 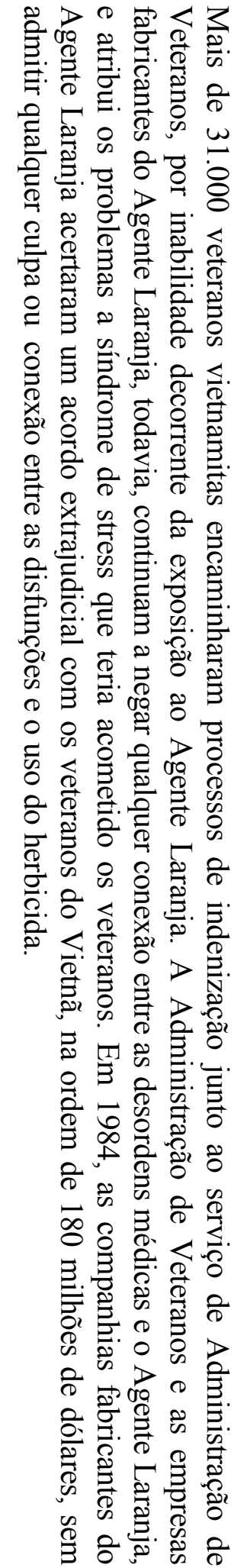 & 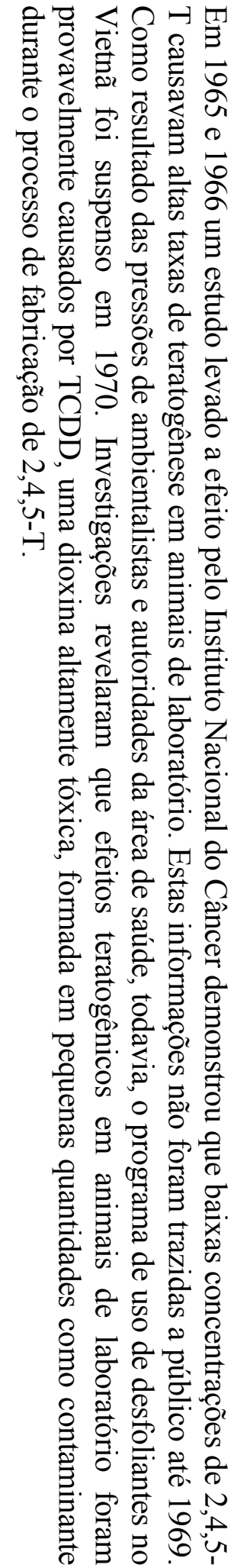 & 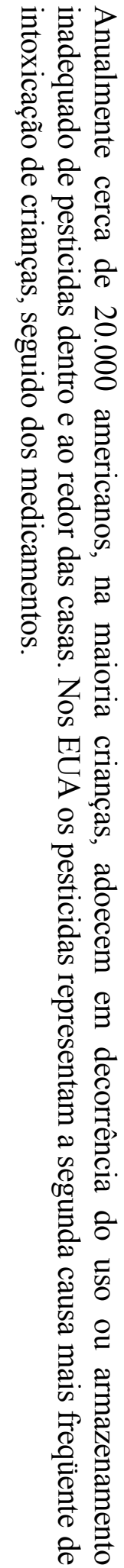 & 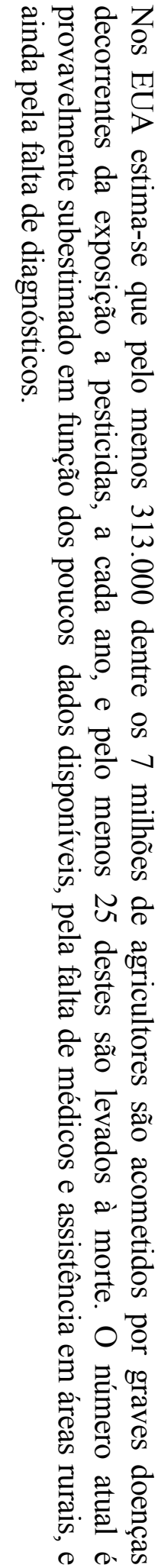 \\
\hline
\end{tabular}




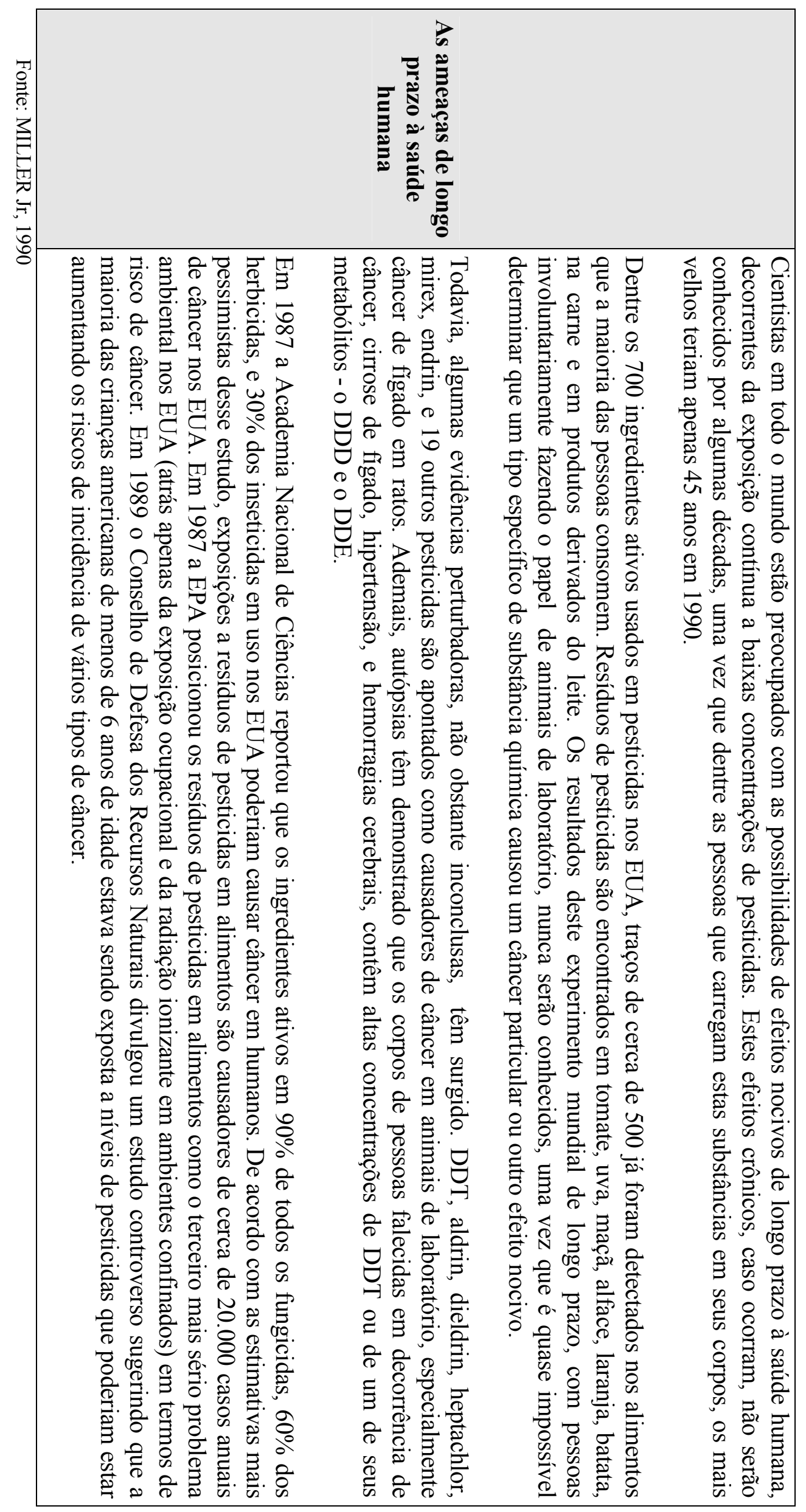


Os anos 90 inauguram uma nova abordagem nos princípios que inspiram o desenvolvimento da indústria de agrotóxicos. Os avanços nos conhecimentos sobre biologia molecular e engenharia genética sinalizam o potencial de exploração visível neste campo, no sentido de agregar produtividade ao conjunto de tecnologias químicas empregadas no combate às pragas e doenças nas atividades agropecuárias e florestais.

As contribuições possíveis nessa associação de técnicas de biologia molecular e dos transgênicos, no aprimoramento da tecnologia dos agrotóxicos englobam os seguintes aspectos (CASSIDA \& QUISTAD, 1998 apud: NRC, 2000):

- aprimoramento das capacidades de produção de agrotóxicos (através das técnicas de células de cultura);

- incremento nas velocidades de descobrimento de novos compostos (através das novas técnicas de screening);

- auxílio no desenvolvimento de culturas transgênicas que produzem suas próprias defesas;

- auxílio no desenvolvimento de inimigos naturais que suportam a exposição aos agrotóxicos convencionais;

- evolução de novos produtos, em termos de modo de ação, estrutura, especificidade e origem.

Estas perspectivas indicam também a necessidade constante do estabelecimento de sistemas de controle para garantir a manutenção das condições de segurança e a saúde, nos âmbitos ocupacionais e ambientais, em níveis satisfatórios e desejáveis, nos contextos de utilização dessa tecnologia. 


\section{2. Os processos que originam as pragas}

A identificação de um organismo biológico denominado como praga está intimamente ligada a um conceito construído. O termo praga não encontra validade biológica e não se refere a qualquer linha taxonômica.

Algumas famílias de insetos podem conter espécies que são consideradas pragas importantes, ao mesmo tempo em que outras espécies membros são reconhecidamente benéficas, por exemplo, na ação como inimigo natural de outras pragas (NEWSOME, 1967 apud NRC, 2000). Também nos casos das plantas o conceito de praga é relativo, considerando que uma mesma espécie pode ser considerada como planta útil para um determinado cultivo, e praga em outra situação, dependendo da circunstância envolvida.

As pragas podem ser simplesmente definidas como qualquer organismo que surge em algum ambiente onde não é bem-vindo. Tal denominação se dá a partir da constatação de que algum tipo de ação direta ou indireta desse organismo passa a interferir na atividade humana, em geral competindo por alimentos ou disseminando doenças.

PASCHOAL (1979), valendo-se de definição apresentada em 1969 pela Academia Nacional de Ciências dos EUA, registra as diversas aplicações atribuídas ao termo praga, em função dos problemas ocasionados por esses organismos:

"O termo praga aplica-se a animais que são capazes de reduzir a quantidade ou a qualidade de alimentos, rações, ferragens, fibras, flores ou madeiras durante a produção, colheita, processamento, armazenagem, transporte ou uso; que podem transmitir doenças ao homem, aos animais domésticos e às plantas cultivadas; que injuriam ou perturbam o homem ou seus animais; que estragam plantas ornamentais, gramados ou essências florestais; ou que danificam propriedades ou objetos de uso pessoa." (PASCHOAL, 1979:15). 
Uma grande variedade de pragas afeta a produção agrícola em todo o mundo. Tais pragas podem ser constituídas de insetos, patógenos, animais e ervas daninhas.

Diversos e complexos fatores influenciam a distribuição e a freqüência do aparecimento das pragas. Variações nas condições ecológicas, agroclimáticas e socioeconômicas de determinada área de cultivo podem definir o quadro de ocorrência das populações de pragas.

O panorama geral das perdas globais de produção agrícolas, por ataque de pragas, estimadas para oito principais culturas, e por região geográfica, pode ser observado nas tabelas 2 e 3 .

Tabela 2 - Produção global atual de oito principais culturas e perdas estimadas, por tipos de pragas, no período de 1988 e 90 - (bilhões US\$).

\begin{tabular}{ccccccc}
\hline \multirow{2}{*}{ Culturas } & $\begin{array}{c}\text { Produção } \\
\text { atual }\end{array}$ & Patógenos & Insetos & $\begin{array}{c}\text { Ervas } \\
\text { daninhas }\end{array}$ & Total & $\begin{array}{c}\text { Produção } \\
\text { total } \\
\text { alcançável }\end{array}$ \\
\hline Arroz & 106,4 & 33,0 & 45,4 & 34,2 & 112,5 & 218,9 \\
Trigo & 64,6 & 14,0 & 10,5 & 14,0 & 38,5 & 103,1 \\
Cevada & 13,7 & 1,9 & 1,7 & 2,0 & 5,7 & 19,4 \\
Milho & 44,0 & 7,8 & 10,4 & 9,3 & 27,4 & 71,4 \\
Batata & 35,1 & 9,8 & 9,6 & 5,3 & 24,8 & 59,9 \\
Soja & 24,2 & 3,2 & 3,7 & 4,7 & 11,6 & 35,8 \\
Algodão & 25,7 & 4,3 & 6,3 & 4,9 & 15,5 & 41,2 \\
Café & 11,4 & 2,8 & 2,8 & 2,0 & 7,6 & 19,0 \\
\hline Fonte: OERKE et al 1995, extraído de YULDELMAN etal, 1998
\end{tabular}

Fonte: OERKE et al, 1995, extraído de YULDELMAN et al., 1998 
Tabela 3 - Produção global atual e perdas estimadas de oito principais culturas, no período de 1988 e 90 , por tipos de pragas e regiões - (bilhões de US\$).

\begin{tabular}{cccccccc}
\hline \multirow{2}{*}{ Regiões } & & \multicolumn{3}{c}{ Perdas atribuídas a } & Produção \\
\cline { 3 - 7 } & Produção & atual & Patógenos & Insetos & Ervas daninhas & Total & $\begin{array}{c}\text { total } \\
\text { alcançável }\end{array}$ \\
\hline África & 13,3 & 4,1 & 4,4 & 4,3 & 12,8 & 26,1 \\
América do Norte & 50,5 & 7,1 & 7,5 & 8,4 & 22,9 & 73,4 \\
América Latina & 30,7 & 7,1 & 7,6 & 7,0 & 21,7 & 52,4 \\
Ásia & 162,9 & 43,8 & 57,6 & 43,8 & 145,2 & 308,1 \\
Europa & 42,6 & 5,8 & 6,1 & 4,9 & 16,8 & 59,4 \\
Antiga União Soviética & 31,9 & 8,2 & 7,0 & 7,0 & 22,1 & 54,0 \\
Oceanía & 3,3 & 0,8 & 0,6 & 0,5 & 1,9 & 5,2 \\
\hline
\end{tabular}

Fonte: OERKE et al, 1995, extraído de YULDELMAN et al., 1998

Pelo menos dois fatores ligados à atividade humana podem ser prontamente identificados como determinantes dos processos que vão definir a incidência e a importância do surgimento das pragas, a saber: a expansão do comércio mundial de alimentos e produtos derivados de plantas; e as mudanças nos padrões de produção das culturas, particularmente a intensificação dos cultivos, a redução na adoção das técnicas de rotação de culturas, e o incremento das monoculturas (YULDEMAN et al., 1998).

Segundo PASCHOAL (1979) o aparecimento de pragas na natureza pode ser explicado por fatores econômicos, históricos e ambientais.

Os fatores econômicos estão ligados ao desenvolvimento das atividades agrícolas e florestais, principalmente baseadas em sistemas de monoculturas, onde o processo de simplificação a que são submetidos esses agroecossistemas li leva a uma situação de instabilidade do equilíbrio biológico, o que faz com que algumas espécies venham a assumir a categoria de pragas.

Os fatores históricos estão relacionados à atividade humana na prática da agricultura dando origem a fatores que propiciam o surgimento de pragas, tais como:

\footnotetext{
i PASCHOAL (1979) utiliza o termo "agroecossistemas" para definir os ecossistemas artificias implantados pelo homem com o objetivo de obtenção de alimentos, fibras, bebidas, drogas, estimulantes, etc.
} 
a. introdução de espécies exóticas em locais mais favoráveis aos seus desenvolvimentos, devido à ausência de inimigos naturais;

b. plantas exóticas favorecendo o aumento populacional de espécies nativas que se tornam pragas quando essas plantas são economicamente exploradas;

c. técnicas de melhoramento genético para aumento da produção que trazem como sub-produto a maior sensibilidade ao ataque de espécies que se convertem em pragas;

d. práticas culturais e de armazenamento inadequadas, favorecendo o crescimento populacional de alguma espécie; dentre outros.

Como fatores ambientais ao surgimento das pragas Paschoal aponta as mudanças climáticas, as quais podem criar condições favoráveis a determinadas espécies, quer pelo aumento da quantidade de alimento disponível, pelo aumento na reprodução ou dispersão das espécies, ou ainda pela ausência de competidores, predadores, parasitas e patógenos.

Os agrotóxicos e o manejo químico dos problemas fitossanitários constituem técnicas adotadas de forma muito presente nos padrões de agricultura praticados nos principais centros mundiais de produção de alimentos, nos últimos 40 anos. Alguns autores sustentam que as perdas globais decorrentes dos ataques de pragas e doenças nas culturas poderiam sofrer insustentáveis elevações de seu nível estimado em 30\%, atingindo cerca de $70 \%$ de perdas na ausência das práticas de controle químico (OERKE et al., 1995 apud YULDEMAN et al., 1998).

Outras avaliações dão conta ainda dos aspectos lucrativos decorrentes do uso de agrotóxicos. Uma destas estimativas sugerem que no EUA, no ano de 1997, para cada US\$1 investido em pesticidas os retornos auferidos foram da ordem de US\$4; desta forma os US $\$ 6,5$ bilhões destinados ao uso de agrotóxicos podem ter representado uma economia de cerca de US\$26 bilhões em perdas das culturas (PIMENTEL, 1997 apud YULDEMAN et al., 1998). 
Entretanto vários autores afirmam que, a despeito dos incrementos crescentes nos volumes de uso mundial de agrotóxicos, observa-se uma modesta diminuição nos índices atuais de perdas das culturas pelo ataque de pragas e doenças.

Dados apresentados pelo Departamento de Agricultura dos EUA mostram que no período entre 1940 e 1990 ocorreu um incremento na ordem de 10 vezes nas quantidades e na toxicidade dos inseticidas utilizados. Todavia, no mesmo período, as perdas das culturas pelo ataque de insetos cresceram de 6 para 13\%; as perdas pela incidência de patógenos elevaram-se de 10 para $12 \%$; enquanto que as perdas pela ação das plantas daninhas sofreram um decréscimo de 14 para 12\%. (PIMENTEL, 1995 apud YULDEMAN et al., 1998:13).

Em outro estudo o mesmo autor aponta que nos EUA, em meados da década de 40, período em que o uso de inseticidas era ainda incipiente, as perdas por pragas na cultura de milho atingiam cerca de $3,5 \%$ da produção. Já na década de 90 , ocasião em que o uso de inseticidas sofre um incremento da ordem de 1000 vezes, atingindo 14 milhões de toneladas por ano, as perdas na cultura do milho foram estimadas em cerca de $12 \%$

Diferentes metodologias e abordagens são empregadas nos diversos estudos que tentam avaliar e relacionar o uso de agrotóxicos e sua efetividade no combate aos problemas de pragas e doenças nas atividades agropecuárias e florestais. Entretanto um ponto comum aparece em várias análises sobre o assunto, ressaltando que a proporção de perdas das culturas pelo ataque de pragas e doenças tem sido crescentes ao mesmo tempo em que quantidades crescentes de agrotóxicos são empregadas em escala global nas últimas décadas.

Autores como YULDEMAN, RATTA \& NYGAARD (1998) fazem referência ao "paradoxo do incremento no uso de agrotóxicos e o incremento das perdas pelas pragas" para tentar identificar esta relação perversa; e uma explicação parcial para tal paradoxo pode ser encontrada na análise do processo de industrialização da agricultura. Esse processo permitiu o desenvolvimento de vastas áreas de agricultura 
altamente dependente de insumos químicos, e ao mesmo tempo incrementou a vulnerabilidade das culturas em relação ao ataque de pragas e doenças.

Os agrotóxicos, principalmente os organossintéticos, constituem os mais poderosos instrumentos humanos de simplificação dos ecossistemas, em função dos desequilíbrios biológicos que proporcionam.

Como conseqüência do uso indiscriminado dos agrotóxicos PASCHOAL (1979) aponta pelo menos quatro tipos de problemas decorrentes no tocante às pragas, quais sejam:

1. Resistência - fenômeno desenvolvido por seleção pré-adaptativa, pelo qual as espécies antes susceptíveis a determinados agrotóxicos, sob pressão dos mesmos, não mais são por eles controladas economicamente nas dosagens normais recomendadas. Indivíduos portadores de genes para resistência ocorrem em pequena percentagem nas populações de espécies suscetíveis ao agrotóxico. As repetidas aplicações de produtos químicos acabam por selecionar tais indivíduos que vão constituindo a maioria da nova população, agora resistente.

2. Ressurgimento - os agrotóxicos reduzem mais drasticamente as populações dos inimigos naturais e competidores do que as das pragas. Sem um controle satisfatório pelos agentes biológicos naturais e com a diminuição da competição intra-específica, as populações residuais das pragas crescem em rápida escala, causando novamente danos econômicos elevados.

3. Desencademanento secundário - pragas secundárias vivendo associadas a pragas principais, em determinadas culturas, são transformadas em problemas, após o tratamento com agrotóxicos que apresentem pequeno ou nenhum efeito sobre estas pragas secundárias, as quais na ausência de inimigos naturais e competidores passam a atuar como pragas principais. 
4. Quebra de cadeias alimentares - agrotóxicos aplicados para combater pragas iniciais de determinadas culturas eliminam essas pragas, sem contudo eliminarem predadores e parasitos. Quebrada a cadeia alimentar dos inimigos naturais estes morrem de fome, emigram ou cessam de reproduzir. Tal situação pode favorecer o estabelecimento de pragas tardias que se instalam na cultura e se reproduzem na ausência de inimigos naturais.

MILLER Jr. (1990) observa que em ambientes naturais é difícil para determinada espécie sobrepor-se, pois o tamanho de suas populações sempre está limitado por outros organismos e pela disponibilidade de nutrientes, luz solar, e outros fatores limitantes.

Apenas cerca de 100 dentre pelo menos 1 milhão de espécies de insetos catalogados causam aproximadamente $90 \%$ dos danos às plantas cultivadas. Em ecossistemas diversificados suas populações são mantidas sob controle pela presença de várias outras espécies que atuam como inimigos naturais. 


\section{3. O consumo mundial de agrotóxicos}

O consumo mundial de agrotóxicos sofreu um rápido incremento na última metade deste século. Entre os anos 50 e 80 o crescimento se deu a uma taxa anual de cerca de $10 \%$ (YULDEMAN et al., 1998).

Mais da metade dos agrotóxicos produzidos mundialmente são consumidos nos Estados Unidos e na Europa Ocidental, regiões estas que abrigam cerca de 25\% das terras globais ocupadas com culturas. Por outro lado cerca de $20 \%$ dos agrotóxicos são consumidos nos países em desenvolvimento que contam com 55\% das terras cultivadas. Uma visão geral sobre os mercados regionais dos agrotóxicos pode ser observada na figura 2, a seguir:

Figura 2 - Divisão mundial do mercado de agrotóxicos em geral e em suas principais classes de uso - 1992.

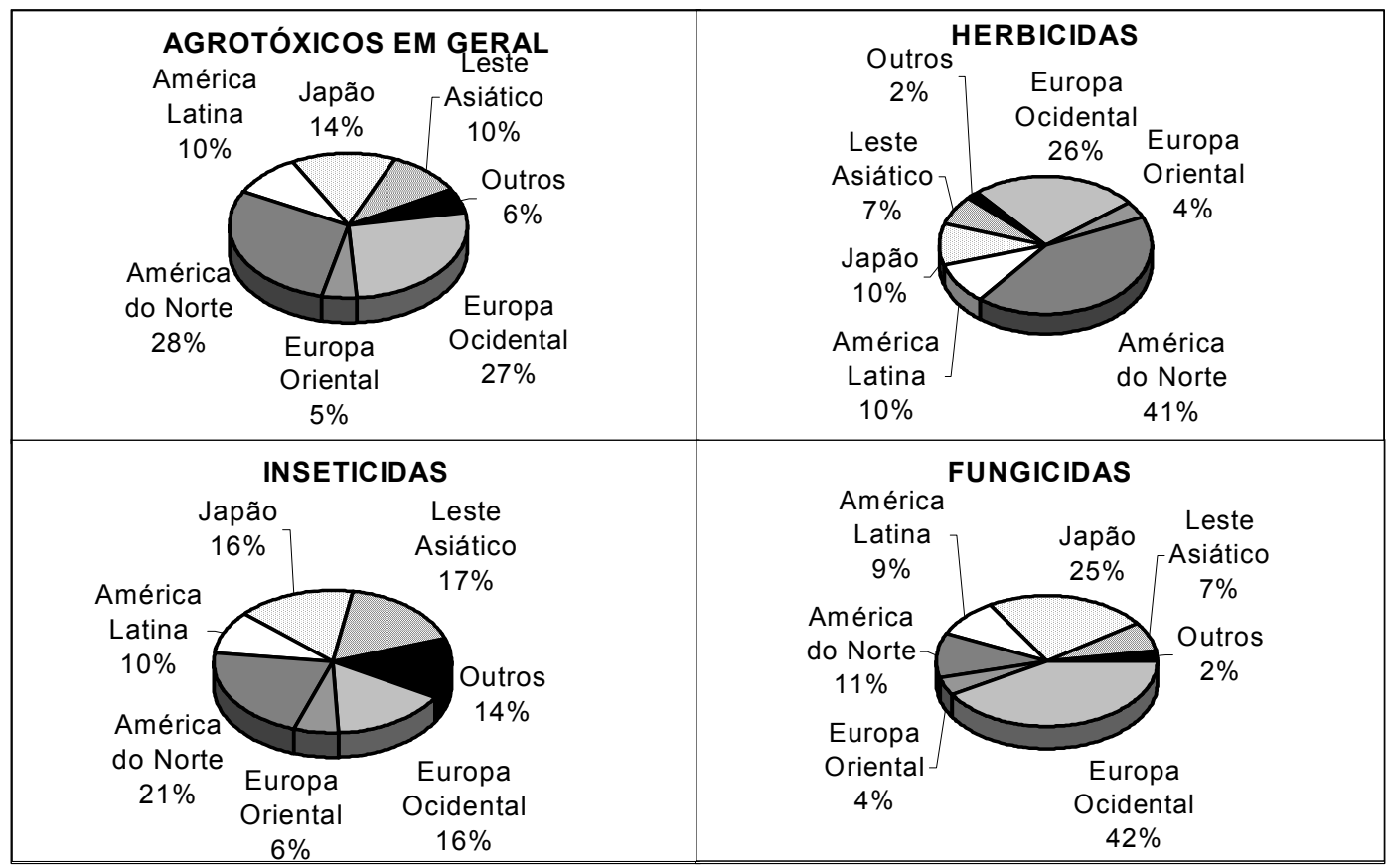

Fonte: modificado de WOOD MACKENZIEe Co.,Ltd, 1993, citado em USAID 1994. In: YUDELMAN, M.; RATTA, A. e NYGAARD, D. (1998) - Pest Management and Food Production - Looking to the Future-

As estimativas atuais de consumo mundial de agrotóxicos são crescentes nos países em desenvolvimento, conforme apontado em estudo realizado pela Organização Mundial de Saúde, através da Divisão de Saúde e Meio Ambiente da Organização Pan- 
americana de Saúde (PAHO). Segundo aponta o estudo, o uso generalizado dos agrotóxicos cresceu de 1,5 milhões de toneladas no ano de 1970 para cerca de 3 milhões em 1985, e estimava-se que nos 10 anos seguintes as vendas deveriam dobrar, especialmente nos países em desenvolvimento.

A tabela 4, a seguir, apresenta a evolução dos gastos com agrotóxicos em alguns países da América Latina, em estimativa realizada pela PAHO em 1993:

Tabela 4 - Despesas* com agrotóxicos em alguns países da América Latina.

\begin{tabular}{cccc}
\hline País & $\mathbf{1 9 8 0}$ & $\mathbf{1 9 8 5}$ & $\mathbf{1 9 9 9}$ \\
\hline & 102 & 164 & 241 \\
Argentina & 9 & 13 & 18 \\
Bolívia & 695 & 1225 & 1993 \\
Brasil & 8 & 12 & 17 \\
Chile & 96 & 155 & 250 \\
Colômbia & 60 & 86 \\
Equador & 14 & 21 & 30 \\
Peru & 7 & 11 & 18 \\
Uruguai & 22 & 38 & 61 \\
Venezuela & 199 & 351 & 565 \\
México & & \\
& & & \\
* Milhões de US\$. Fonte: BURTON et al, 1988, In: PAN AMERICAN HEALTH ORGANIZATION. \\
Pesticides and Health in the Americas, Environmental Series no 12. Washington, DC, PAHO, 1993. 109 P.
\end{tabular}

Estas estimativas feitas em 1993 foram superadas pelos fatos constatados posteriormente, e a evolução do consumo aconteceu de forma mais acentuada que o previsto.

Em 1995, na Argentina, as vendas já superavam em 2,5 vezes os valores estimados para 1999. No caso do Chile a previsão da PAHO para 1999 foi superada em cerca de 7,5 vezes, já no ano de 1995. Para o Brasil os valores realizados em 1995 já representavam cerca de $78 \%$ da estimativa de vendas feita para 1999 (Tabela 5). 
Tabela 5 - Vendas de agrotóxicos (US\$ milhões) nos países do Mercosul, segundo as principais classes de uso, 1995.

\begin{tabular}{|c|c|c|c|c|c|}
\hline \multirow{2}{*}{ Países } & \multicolumn{4}{|c|}{ Classes de uso } & \multirow{2}{*}{ Total } \\
\hline & Inseticidas & Fungicidas & Herbicidas & Outros & \\
\hline Argentina & 108,8 & 42,4 & 434,0 & 17,9 & 603,1 \\
\hline Brasil & 435,2 & 226,4 & 834,1 & 39,6 & 1535,2 \\
\hline Chile & 36,6 & 32,8 & 59,2 & & 128,6 \\
\hline Paraguai & 18,8 & 5,5 & 36,2 & 0,3 & 60,8 \\
\hline Uruguai & 3,4 & 8,2 & 14,8 & 1,8 & 28,3 \\
\hline Total & 602,8 & 315,3 & 1378,3 & 59,6 & 2356,0 \\
\hline
\end{tabular}

$\mathrm{O}$ estudo da PAHO/OMS também faz referência aos valores das vendas mundiais de agrotóxicos que cresceram cerca de oito vezes em duas décadas, evoluindo de US\$ 2,700 milhões em 1970, para US\$ 15,900 em 1980, atingindo US\$ 21,500 milhões em 1990. Em 1989 vinte empresas controlavam o mercado mundial, sendo que as primeiras dez respondiam por $72 \%$ das vendas (Tabela 6 ).

Tabela 6 - Vendas mundiais de agrotóxicos realizadas pelas principais empresas produtoras em 1993.

\begin{tabular}{ccc}
\hline & EMPRESA & US\$ MILHÕES \\
\hline & & \\
1 & Ciba Geigy & 2,271 \\
2 & ICI & 2,026 \\
3 & Bayer & 1,862 \\
4 & Du Pont & 1,684 \\
5 & Rhone Poulenc & 1,646 \\
6 & Monsanto & 1,558 \\
7 & Dowelanco & 1,485 \\
8 & Hoechst & 1,090 \\
9 & BASF & 1,032 \\
10 & Shell & 903 \\
11 & AmericanCyanamid & 820 \\
12 & Schering & 740 \\
13 & Sandoz & 713 \\
14 & Kumial & 420 \\
15 & FMC & 414 \\
16 & Rohm and Haas & 367 \\
17 & Sankyo & 344 \\
18 & Nihon Nohyaku & 318 \\
19 & Takeda & 268 \\
20 & Hokko & 265 \\
& & \\
\hline Fonte: AGROW, 1990 In: PAN AMERICAN HEALTH ORGANIZATION.Pesticides and Health in the Americas, Environmental \\
Series ${ }^{\circ}$ 12. Washington, DC, PAHO, 1993. 109 P.
\end{tabular}




\section{4. O mercado de consumo no Brasil}

Construir um quadro histórico geral sobre os números que envolvem o uso de agrotóxicos no Brasil constitui tarefa árdua, tendo em vista a pouca disponibilidade de dados, reflexo da fragilidade dos órgãos responsáveis pela fiscalização desses insumos, os quais não apresentam condições de recolher ou mesmo dar tratamento e divulgação adequada às poucas informações disponíveis.

A Associação Nacional de Defesa Vegetal - ANDEF e o Sindicato Nacional da Indústria de Defensivos Agrícolas divulgam periodicamente os valores das vendas realizadas no país, mas a divulgação de informações sobre as quantidades vendidas, por região e por cultura, já não é tão constante, tornando difícil avaliar a real situação de uso no país.

A reunião de alguns dados disponíveis na literatura permitiu a montagem de um quadro geral de vendas de agrotóxicos no Brasil, contemplando valores de vendas, quantidades de produto comercial vendido, quantidades de ingredientes ativos vendidos e preços médios dos agrotóxicos, no período de 1972 a 1989 e de 1997 a 1998. Estes dados são mostrados nas tabelas 7, 8, 9, e 10 apresentadas a seguir. 


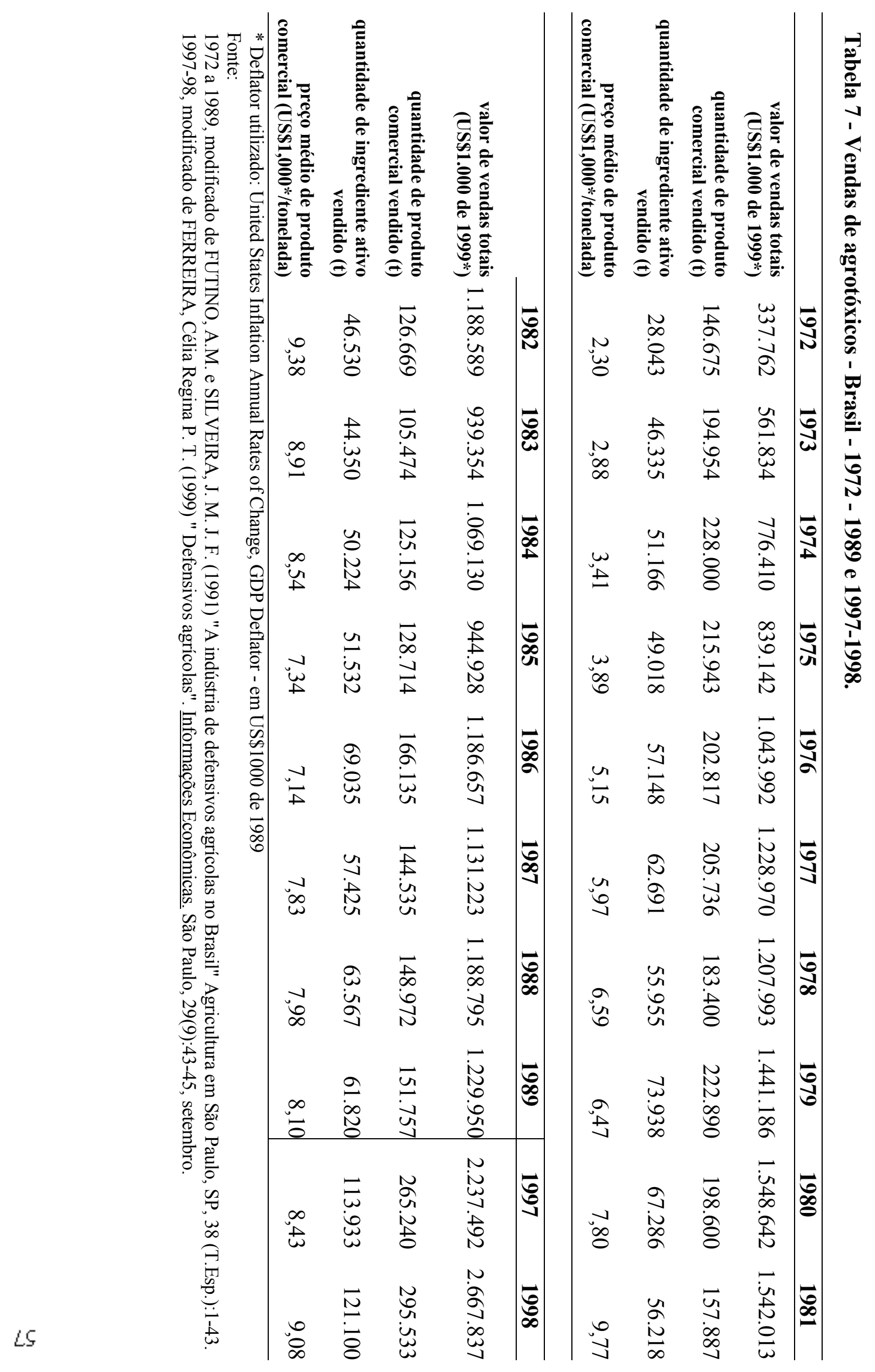




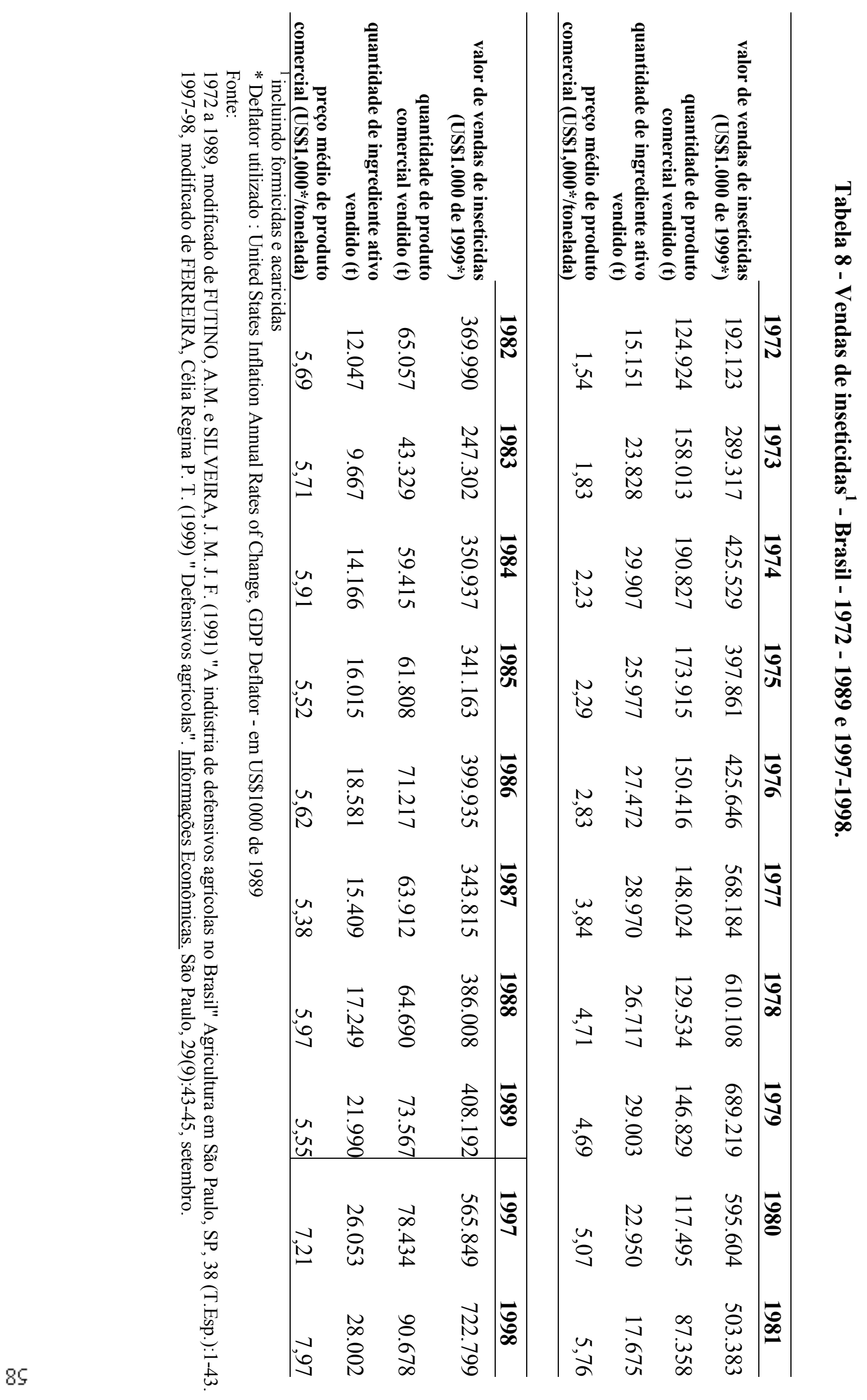




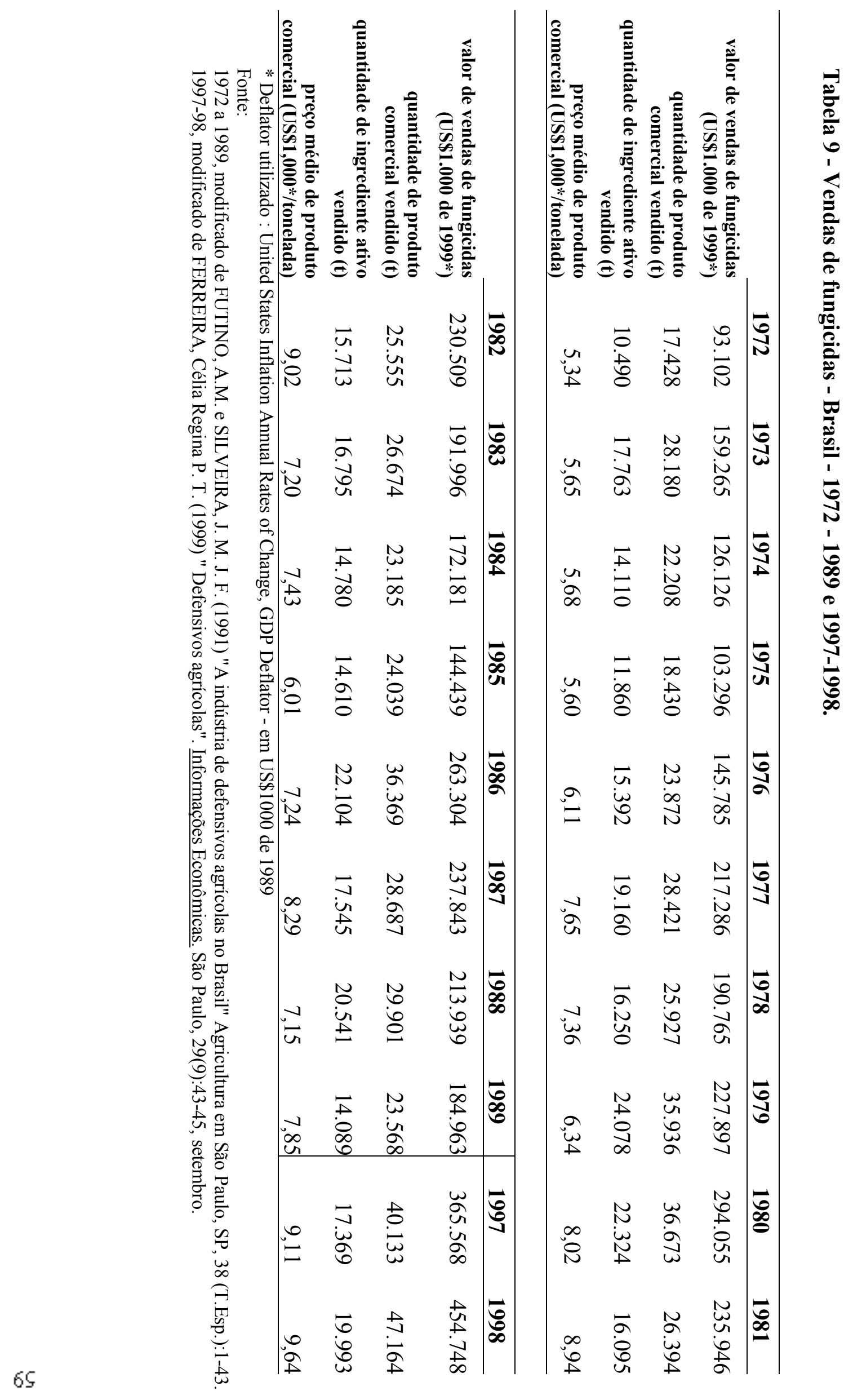




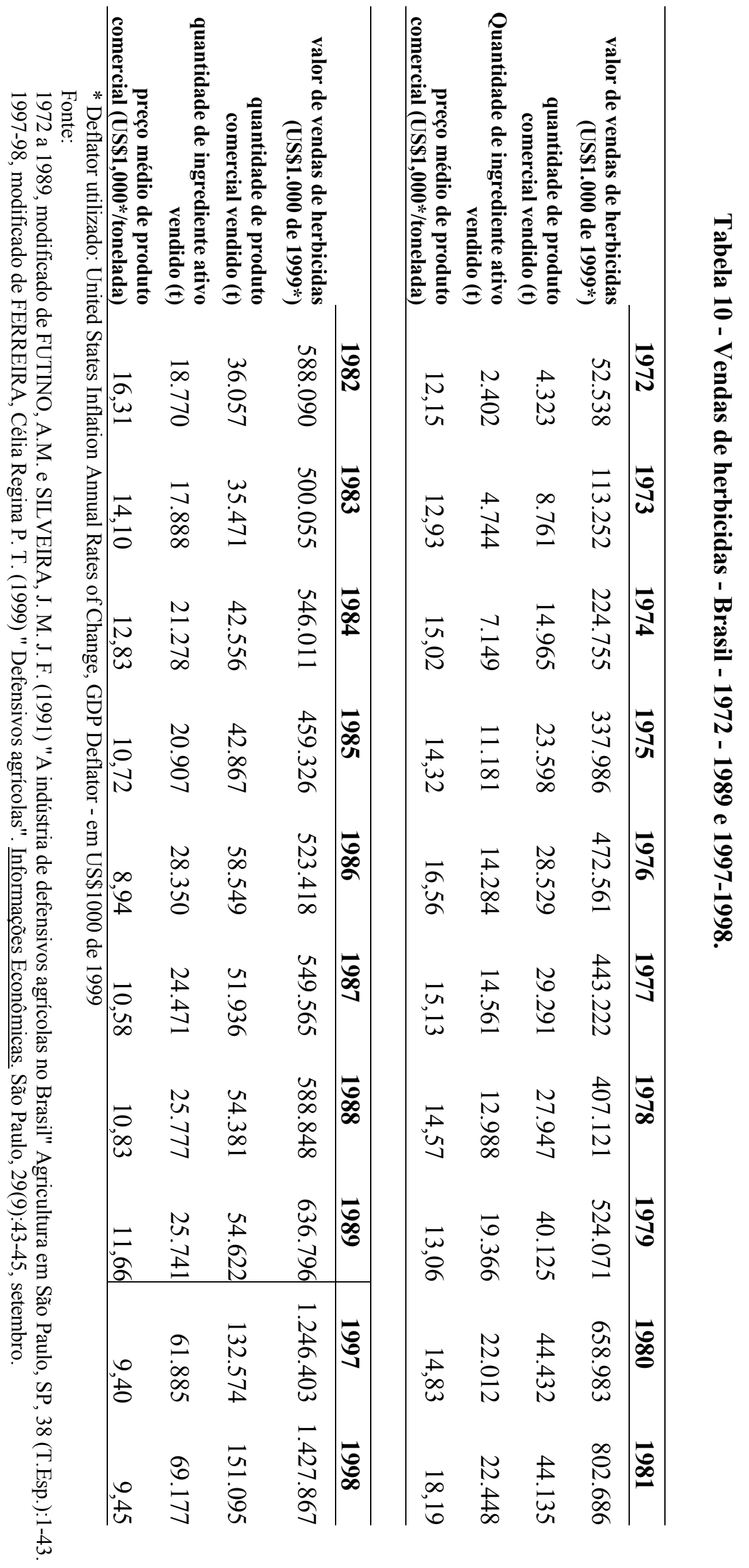


Cerca de $80 \%$ do mercado de agrotóxicos no Brasil está concentrado no movimento de aproximadamente 10 empresas, em sua maioria constituída por grandes corporações transnacionais, e que no Brasil têm seus interesses representados através da associação que as congrega, a ANDEF. Em 1999, a partir dos processos de fusões ocorridos no ramo da industria química mundial, a concentração do mercado ficou ainda mais acentuada, passando de 10 para 8 o número de empresas que controlam cerca de $80 \%$ do mercado de agrotóxicos no Brasil. (Tabelas 11 e 12).

Tabela 11 - Participação das principais empresas atuantes no mercado de agrotóxicos no Brasil, no ano de 1999.

\begin{tabular}{ccc}
\hline Empresas & Faturamento em US\$ 1000 & Participação no mercado (\%) \\
\hline AVENTIS & 299.000 & 12,8 \\
NOVARTIS & 287.000 & 12,3 \\
MILÊNIA & 191.000 & 8,2 \\
MONSANTO & 187.000 & 8,0 \\
CYANAMID & 177.000 & 7,6 \\
DUPONT & 176.000 & 7,3 \\
ZENECA & 176.000 & 7,3 \\
BAYER & 159.000 & 6,8 \\
BASF & 138.000 & 5,9 \\
FMC & 90.000 & 3,8 \\
\hline TOTAL BRASIL & 2.329 .583 & 100,0 \\
\hline Fonte: WACKIN, 2000 & &
\end{tabular}

Tabela 12 - Participação das principais empresas atuantes no mercado de agrotóxicos no país, após os processos de fusões . Brasil - 1999.

\begin{tabular}{ccc}
\hline Empresas & $\begin{array}{c}\text { Faturamento em US\$ } \\
1000\end{array}$ & $\begin{array}{c}\text { Participação no } \\
\text { mercado (\%) }\end{array}$ \\
\hline CINGENTA (NOVARTIS + ZENECA) & 463.000 & 19,7 \\
BASF (+ CYANAMID) & 315.000 & 13,4 \\
AVENTIS (RHODIA + HOESCHT) & 299.000 & 12,8 \\
MILÊNIA (HERBITÉCNICA + DEFENSA) & 191.000 & 8,2 \\
MONSANTO & 187.000 & 8,0 \\
DUPONT & 176.000 & 7,3 \\
BAYER & 159.000 & 6,8 \\
FMC & 90.000 & 3,8 \\
TOTAL (OITO MAIORES) & 1.880 .000 & 80,0 \\
TOTAL BRASIL & 2.329 .583 & 100,0 \\
\hline
\end{tabular}

Fonte: WACKIN, 2000 
Seguindo a tendência observada no consumo mundial, os maiores gastos com agrotóxicos são realizados na compra de produtos pertencentes à classe dos herbicidas. Estes respondem por cerca de 55\% do volume de vendas dos últimos anos, seguidos dos inseticidas e fungicidas. A evolução da participação das diferentes classes de agrotóxicos no volume total de vendas realizadas em três períodos (1972 a 1982; 1982 a 1992; e 1992 a 1999), no Brasil, é apresentada nas figuras 3, 4, e 5 a seguir.

Figura 3 - Vendas de agrotóxicos, segundo as principais classes de uso. Brasil 1972 a 1982 - (em US\$ 1000 de 1999) ${ }^{1}$.

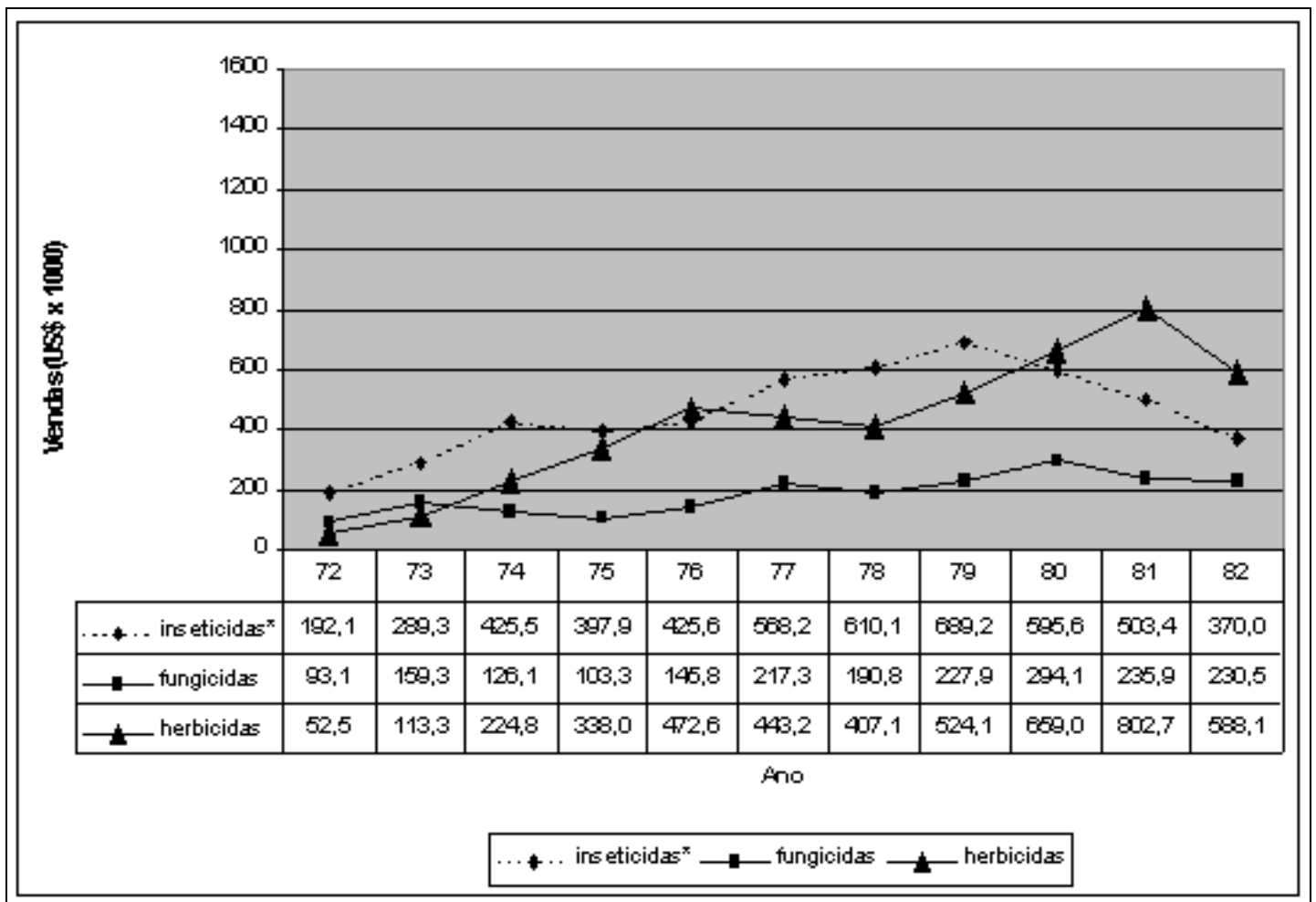

${ }^{\mathrm{I}}$ Deflator utilizado: United States Inflation Annual Rates of Change, GDP Deflator - em US\$1000 de 1999 * inclui formicidas e acaricidas

Fonte: modificado de FUTINO, A.M. e SILVEIRA, J. M. J. F. (1991) 
Figura 4 - Vendas de agrotóxicos, segundo as principais classes de uso. Brasil 1982 a 1992 - (em US\$ 1000 de 1999)1.

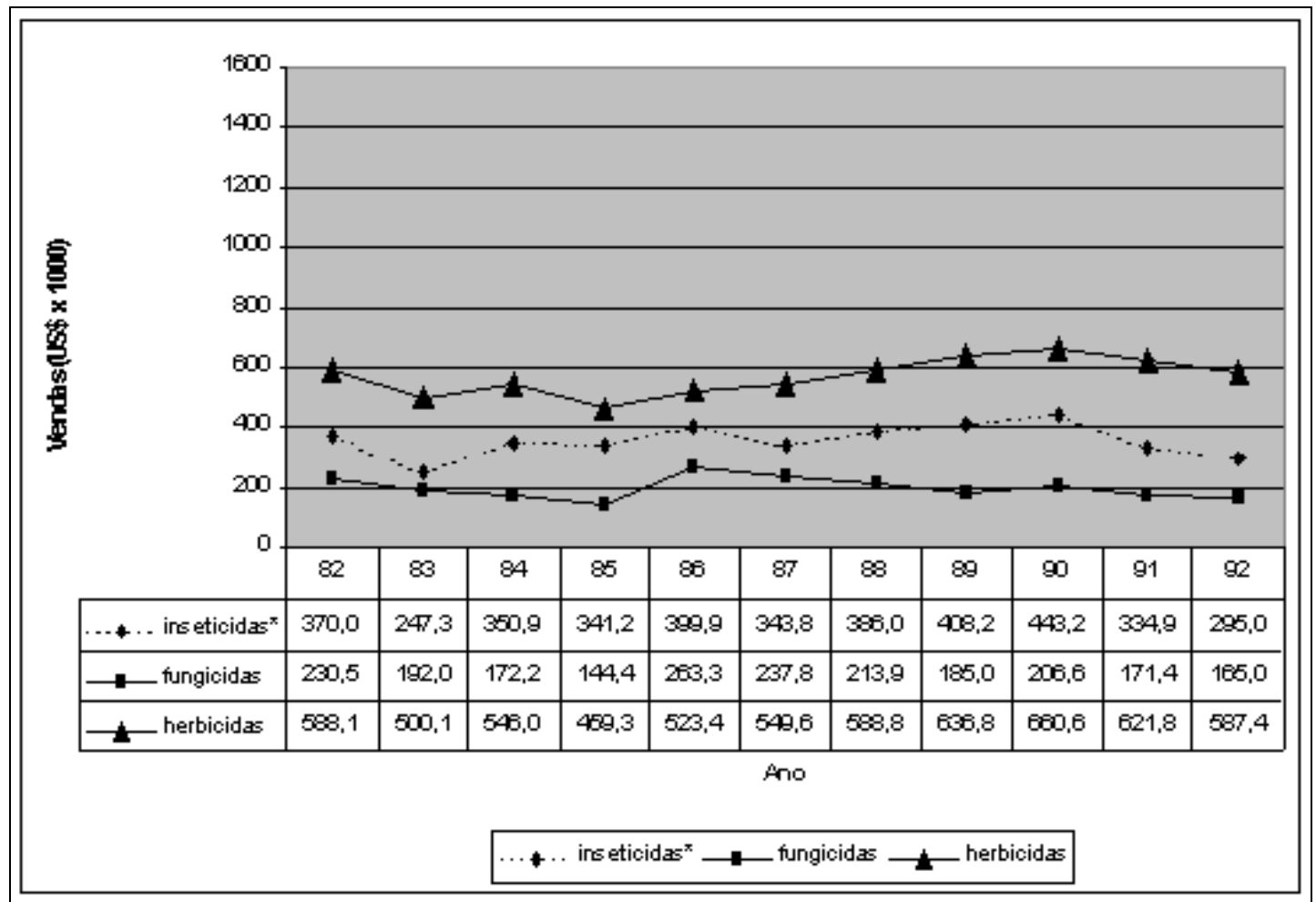

${ }^{\mathrm{I}}$ Deflator utilizado: United States Inflation Annual Rates of Change, GDP Deflator - em US\$1000 de 1999 * inclui formicidas e acaricidas

Fonte:

1982 a 1989, modificado de FUTINO, A.M. e SILVEIRA, J. M. J. F. ( 1991)

1990 a 1992, modificado de SINDAG 
Figura 5 - Vendas de agrotóxicos, segundo as principais classes de uso. Brasil 1992 a 1999 - (em US\$ 1000 de 1999)1.

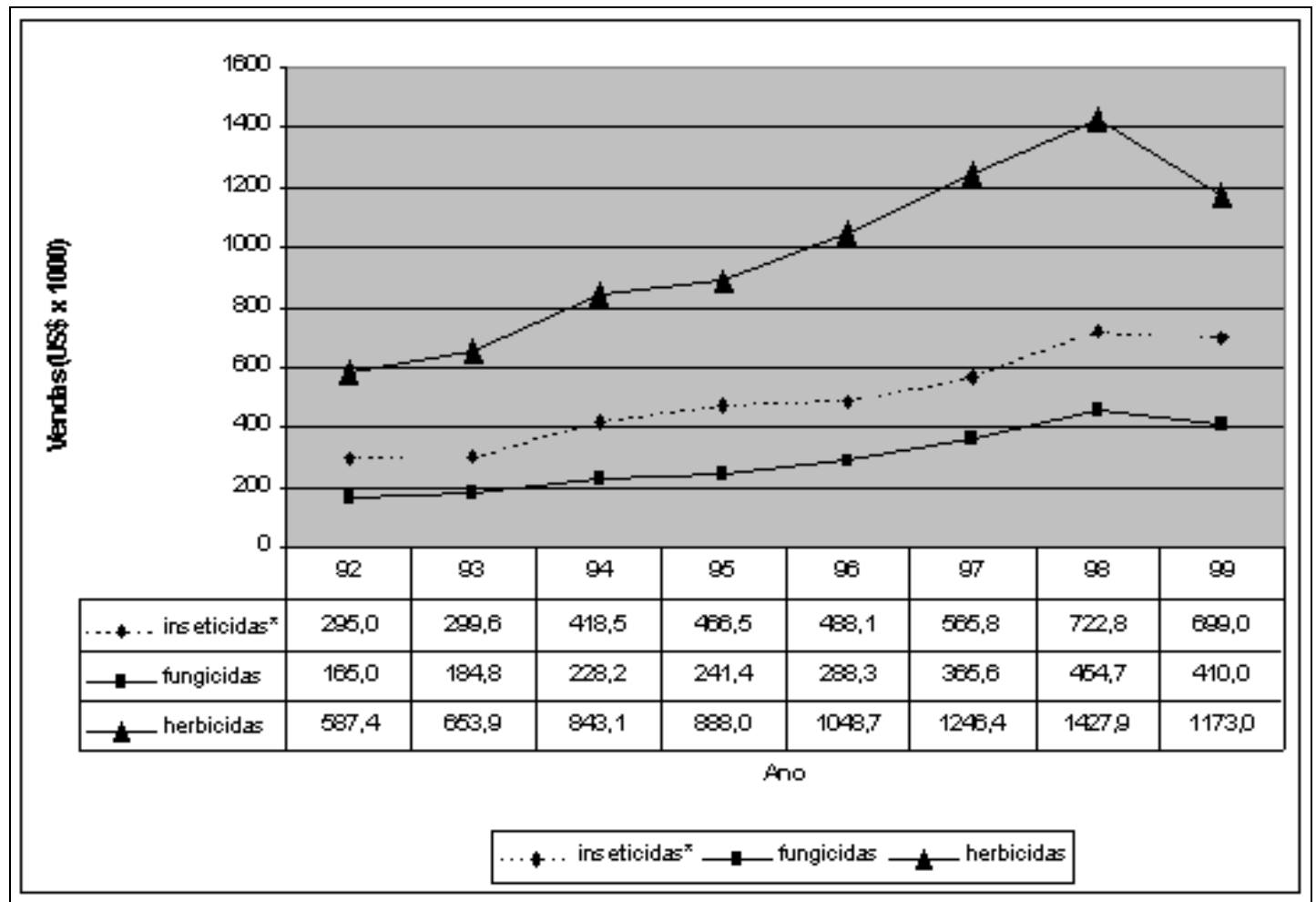

${ }^{\mathrm{I}}$ Deflator utilizado: United States Inflation Annual Rates of Change, GDP Deflator - em US\$1000 de 1999 * inclui formicidas e acaricidas

Fontes:

1992 a 1994, modificado de SINDAG

1995, modificado de IEA (1999)

1996-98, modificado de FERREIRA (1999)

1999, ANDEF (2000)

A figura 6 mostra a evolução dos valores totais das vendas de agrotóxicos no Brasil, segundo os vários estados consumidores, em dois momentos: 1985 e 1996. Em 1996 os estados de São Paulo, Paraná e Rio Grande do Sul responderam em conjunto por cerca de $61 \%$ do total das vendas realizadas, e dentre estes o maior incremento de vendas no período foi observado no estado do Paraná (156\%). São Paulo e Rio Grande do Sul apresentaram, respectivamente, incrementos de $135 \%$ e $93 \%$. 
Figura 6 - Vendas* de agrotóxicos no Brasil, em 1985 e 1996, segundo as unidades da federação.

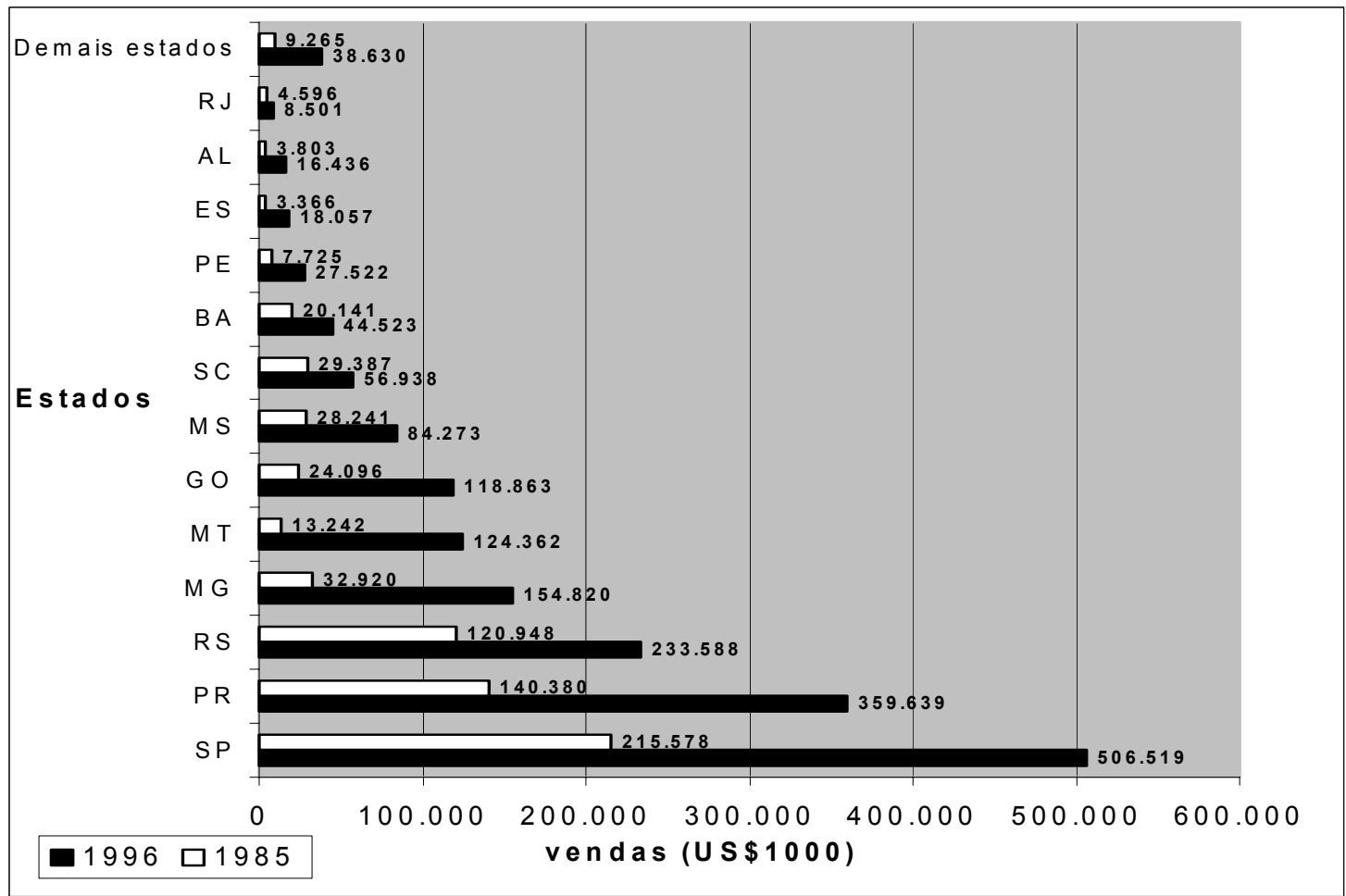

** vendas em US\$1000 - Fonte: SINDAG - Sindicato Nacional da Indústria de Defensivos Agrícolas

Um dos pontos de destaque ao se buscar o desenho de um quadro geral dos agrotóxicos no Brasil diz respeito ao número considerável de produtos comerciais disponíveis no mercado. Os dados oficiais do Ministério da Agricultura, órgão responsável pelo registro destes produtos no país, apontavam em 1998 um universo de cerca de 1952 produtos disponíveis para uso (Figura 7). 
Figura 7 - Distribuição dos produtos registrados no Ministério da Agricultura, segundo classes gerais de uso - Brasil - 1998.

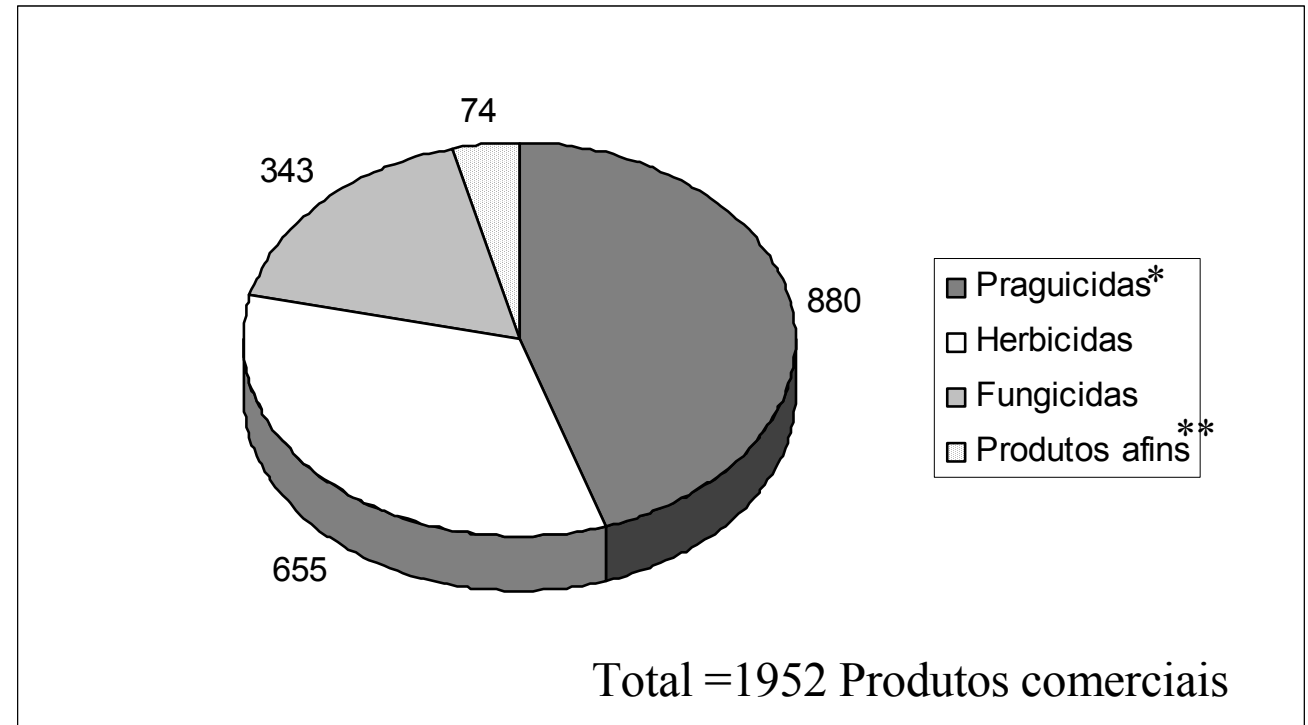

*Inseticidas, acaricidas, bactericidas, cupinicidas, formicidas, fumigantes, moluscicidas

** Adesivos, adjuvantes, espalhantes, estimulantes, estimulantes de crescimento, estimulantes vegetativos, maturadores

Fonte: Ministério da Agricultura e Abastecimento. Agrofit 98. Informações de produtos fitossanitários registrados no MA [programa de computador]. Brasília, Coordenação de Fiscalização de agrotóxicos, 1998.

Bases de dados mais recentes produzidas por empresas especializadas no acompanhamento dos processos de registro de agrotóxicos junto aos órgãos reguladores possibilitam a definição mais precisa do panorama geral dos produtos em uso no país.

Em agosto de 2000 havia 444 ingredientes ativos registrados no Brasil. Estes produtos técnicos davam origem a mais de 850 produtos comerciais distribuídos nas diversas classes de uso (herbicidas, inseticidas, fungicidas, acaricidas, nematicidas, formicidas, antibrotantes, reguladores de crescimento, etc).

$\mathrm{Na}$ prática, considerando-se as diversas possibilidades de apresentação destes produtos comerciais (embalagens, volumes, etc), 1981 produtos comerciais tinham uso autorizado no país, em agosto de 2000.

Este número pode ser considerado pequeno se comparado às quantidades de produtos registrados em países desenvolvidos (nos Estados Unidos há cerca de 50.000 produtos registrados para uso -YUDELMAN et al.,1998:9), mas certamente representa 
um enorme desafio quando se imagina que o exercício da prescrição técnica destes produtos deve pressupor o conhecimento das características e das aplicações de grande parte destas possibilidades.

Um panorama geral e atualizado dos ingredientes ativos, produtos comerciais e suas diversas apresentações, com uso autorizado no Brasil, representa uma informação básica que deveria estar acessível aos interessados e, de forma especial, aos profissionais responsáveis pela prescrição técnica desses produtos. Entretanto o órgão governamental que mantém o registro dos agrotóxicos não dispõe de um sistema ágil para recuperar e difundir estas informações na mesma dinâmica em que elas são geradas.

A ausência deste serviço por parte do órgão oficial registrante é suprida pela atuação de empresas privadas especializadas, as quais, através do acompanhamento cotidiano das publicações feitas no Diário Oficial sobre as condições de registro de cada produto, compõem bancos de dados técnicos cujo acesso é vendido como prestação de serviços ao público interessado.

Um panorama do número de ingredientes ativos, produtos comerciais e apresentações de produtos comerciais registrados no Brasil, nos anos de 1996 a 2000, é mostrado nas tabelas 13,14 e 15 . 

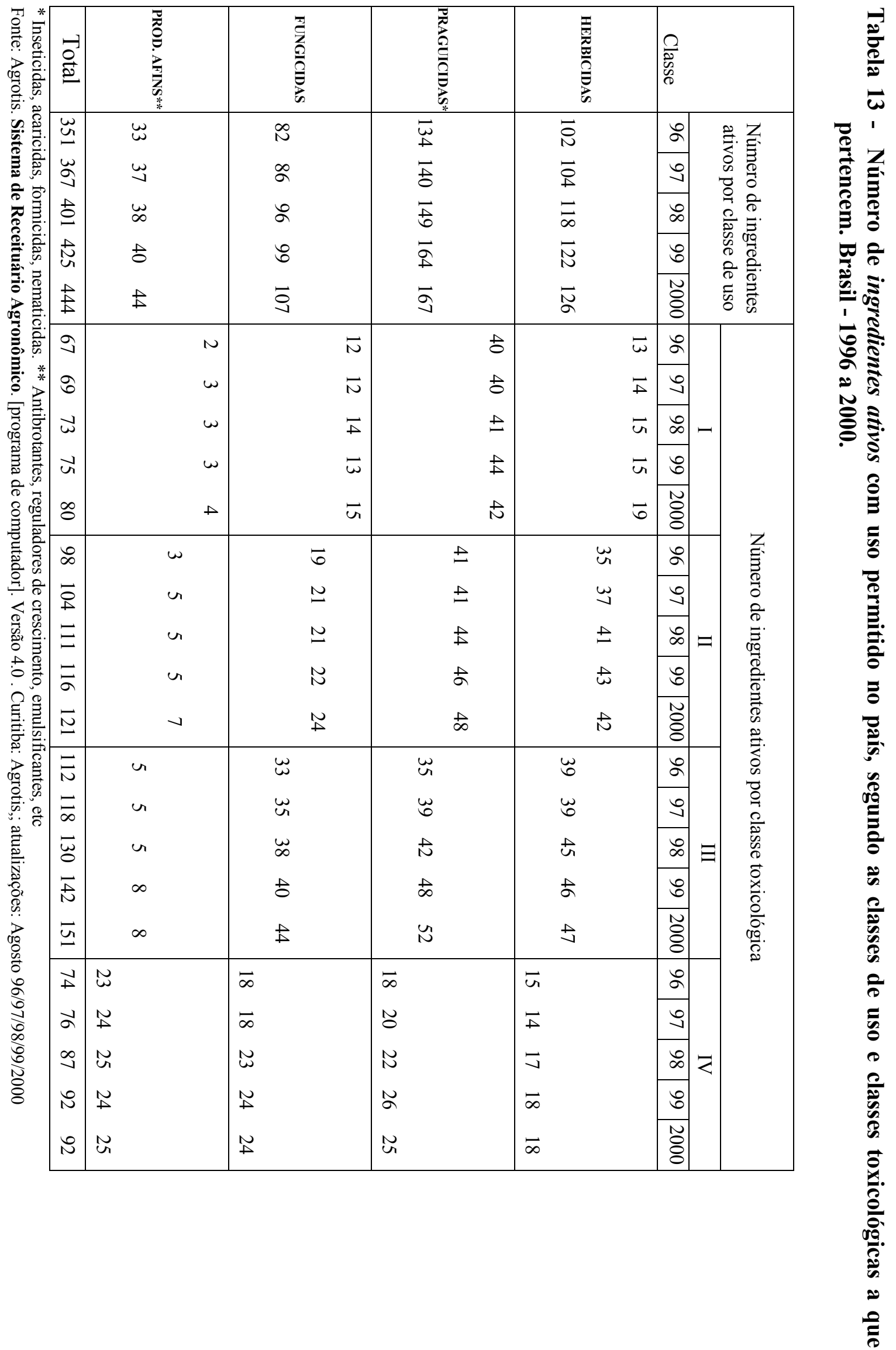

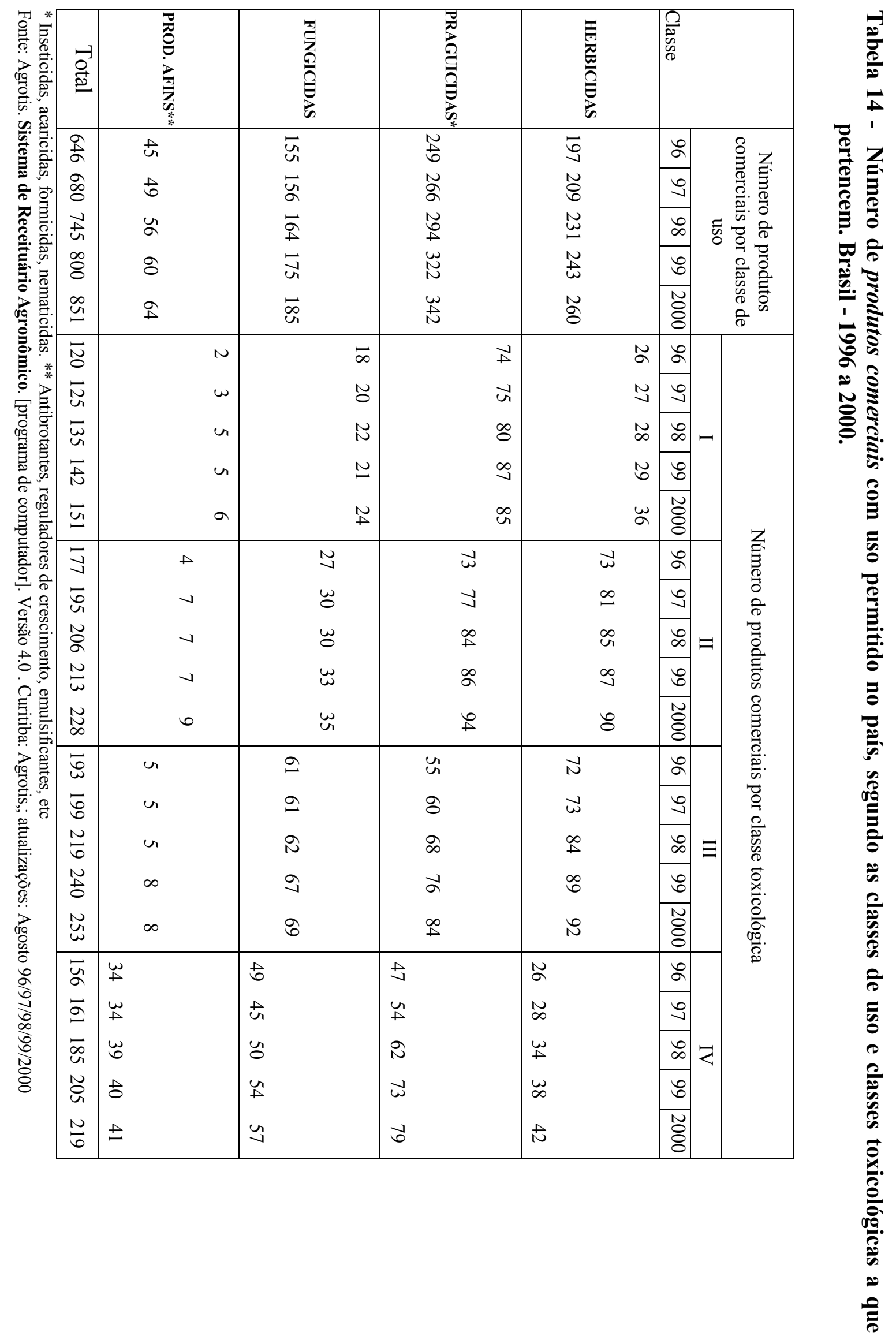

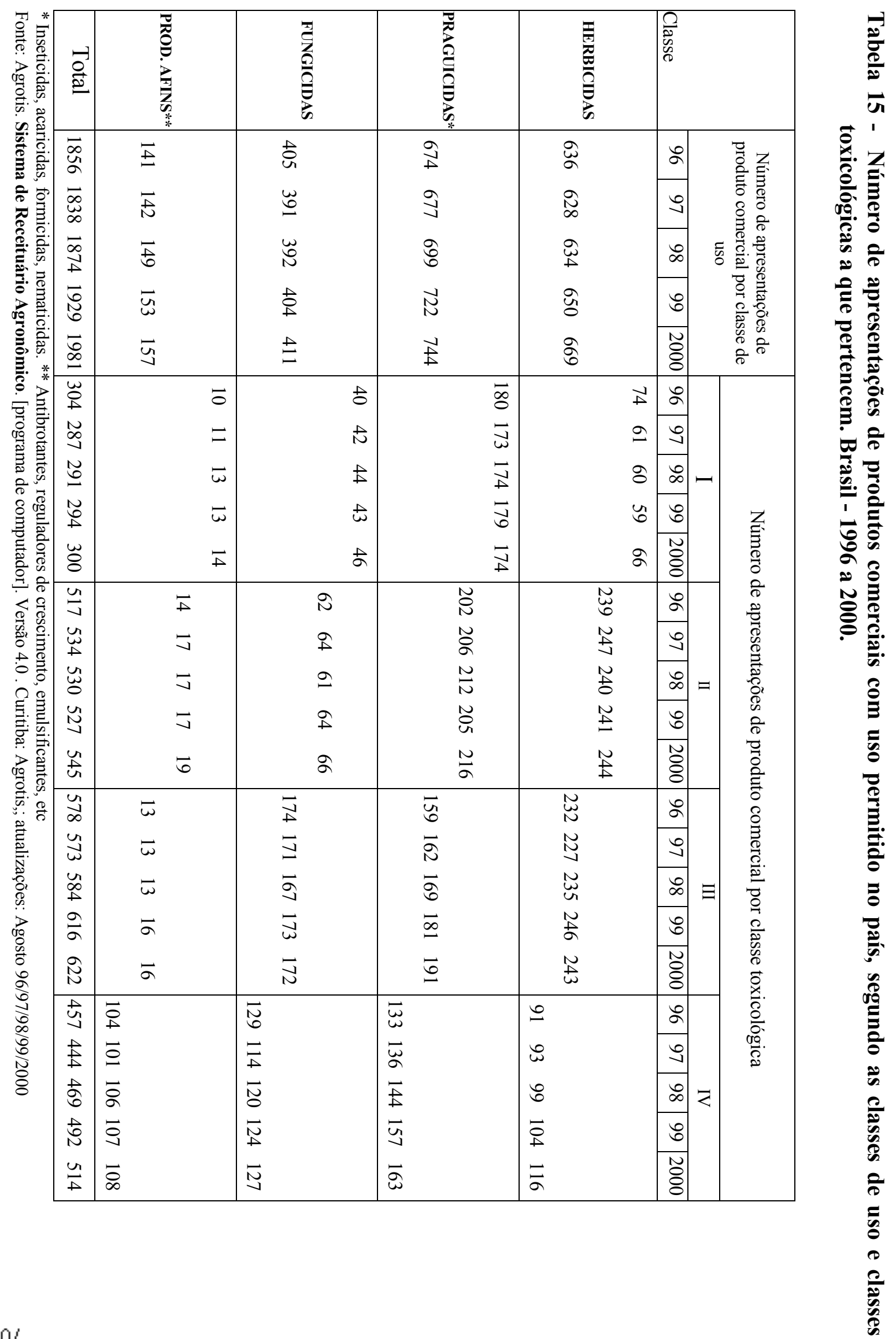


\section{A DIFUSÃO DO CONTROLE QUÍMICO NA AGRICULTURA BRASILEIRA}

No Brasil, a aplicação de produtos químicos como forma de combate aos problemas decorrentes da incidência de doenças e pragas nas atividades agropecuárias percorre três fases distintas e, segundo definem GUERRA \& SAMPAIO (1991), três conceitos diferentes fundamentam tais fases.

Inicialmente a introdução dos agrotóxicos é feita de forma desordenada, acompanhada de um pacote tecnológico que introduzia a mecanização em larga escala, associada a outros fatores de produção. Nesta fase o enfoque básico era o aumento da produtividade, sem considerar riscos à saúde ou ao ambiente.

A valorização da estética dos produtos agrícolas, no contexto das atividades de comercialização, sustentava a base da utilização maciça do controle químico como única alternativa capaz de garantir os índices de produtividade e a qualidade estética dos produtos agrícolas, nos padrões necessários e exigidos para o consumo.

Assim, com a importante ajuda da propaganda, nos diversos meios de comunicação, a tecnologia química é introduzida no campo sem nenhuma preocupação com adaptações às condições ecológicas e sócio-econômicas da agricultura tropical.

Numa segunda fase, a partir da década de 70 aproximadamente, começa a surgir o reconhecimento dos riscos decorrentes do uso abusivo dos agrotóxicos, a partir da identificação dos diversos casos de contaminação ambiental e de problemas de saúde pública originados pela prática do controle químico na agricultura. 
Os casos de intoxicações de trabalhadores rurais, as constatações de resíduos em alimentos, as contaminações de solo e de coleções de água, além dos novos conhecimentos sobre a toxicologia das substâncias químicas utilizadas, constituem fatores que contribuem de forma significativa para a construção de um novo entendimento a respeito das implicações do uso de agrotóxicos.

O crescente reconhecimento social dos riscos presentes no uso de agrotóxicos seria então o catalisador de iniciativas crescentes no sentido de se buscar adequações tecnológicas para a racionalização do uso dos agrotóxicos. O próprio conceito de pragas e as formas de como enfrentar o problema do manejo fitossanitário passa de uma visão quase que individualista da relação inseto (praga) e hospedeiro (planta), para alcançar o modelo que considera a dinâmica das populações envolvidas.

PASCHOAL (1982) constata através de estudo sobre a evolução das pragas na agricultura brasileira que até 1958 apareciam 193 referências sobre pragas nas culturas estudadas; de 1958 a 1963 esse número foi acrescido por outras 50 espécies, totalizando-se 243. Já no período entre 1963 e 1976, o acréscimo atingiu 350 novas espécies de pragas referidas, elevando-se o total para 593 pragas em 1976.

A correlação entre o aumento do número de pragas constatadas e o consumo de agrotóxicos no período foi positiva. A partir de estudos como este o conceito ecológico, como base para entendimento e interferência nas questões relacionadas à produção agrícola e o manejo das pragas e doenças, passa a ser difundido, ainda de forma modesta mas numa trajetória irreversível.

É então neste cenário que surgem no Brasil novos métodos como o chamado M.I.P.- Manejo Integrado de Pragas, já praticados em outros países, tentando-se associar o controle químico com outros métodos existentes.

Ao final dos anos oitenta, ainda com o crescimento dos eventos relacionados a desastres ecológicos e de problemas de saúde ocupacional e ambiental, começam a 
surgir no Brasil novos processos de reorganização da sociedade, a partir de discussões políticas e da construção de novos instrumentos legais pela nova Constituição.

A adoção de um novo enfoque na questão do uso de agrotóxicos começa a prosperar em vários países, a partir da constatação técnica e econômica dos benefícios possíveis de serem alcançados através da adoção de políticas de redução e substituição do uso destes insumos.

\section{1. A consolidação do uso de agrotóxicos no Brasil}

A produção de agrotóxicos em grau técnico no Brasil foi iniciada há cerca de cinqüenta anos, com o surgimento da indústria de formulações em 1948.

As campanhas de caráter fitossanitário iniciadas entre 1946 e 1948, com o emprego de BHC, DDT e Parathion, visando enfrentar os problemas desencadeados pela presença de pragas como o gafanhoto migratório, a broca-do-café e as pragas do algodoeiro, aumentaram a demanda pelos produtos formulados. Assim, ao início dos anos 50 já havia no país uma florescente indústria de formulação, que operava no processamento de produtos técnicos importados e também a partir de produtos obtidos localmente (Parathion e BHC).

SILVEIRA \& FUTINO (1990) analisando o processo de internalização da estrutura produtiva da indústria de agrotóxicos no Brasil, estabelecem quatro períodos diferenciados desse desenvolvimento entre o pós-guerra e os anos 90:

1. do pós-guerra ao final dos anos 60: período onde prevaleceu a política liberal dos órgãos governamentais envolvidos nos processos de importação de ingredientes ativos e de formulações. Nesse período a produção brasileira estava limitada a alguns organoclorados de uso bastante generalizado, tais como o DDT e o BHC; 
2. do final dos anos 60 a 1974: período marcado pelo posicionamento do Conselho de Política Aduaneira (CPA) no sentido de estabelecer uma política de ajustamento das taxas de importação ao nível de preços das empresas nacionais, visando evitar o "dumping" contra as empresas aqui instaladas, por parte de empresas líderes mundiais que exportavam para o Brasil;

3. de 1974 a 1980: implementação de uma política aduaneira seletiva, combinando isenções para as importações de princípios ativos com a proteção às formulações feitas em âmbito local. É também neste período que se estabelecem o II PND - Plano Nacional de Desenvolvimento, e ainda o PNDA - Plano Nacional de Defensivos Agrícolas (1975). A política de crédito de custeio para agricultura é bastante incrementada com recursos. É ainda neste período que a indústria nacional de agrotóxicos ganha acelerado crescimento;

4. de 1981 a 1990: período até 1985 é marcado pela retração de demanda; com retomadas do mercado após esse período, mas sempre oscilando de acordo com os movimentos de instabilidade das principais culturas consumidoras de agrotóxicos.

Analisando o perfil do Plano Nacional de Defensivos Agrícolas (PNDA) SILVEIRA \& FUTINO (1990) observam que o plano foi criado em 1975 com o objetivo de motivar a internalização de etapas produtivas finais de agrotóxicos, visando a redução das importações, a redução dos preços dos produtos, e ainda a geração de excedentes exportáveis.

PESSANHA \& MENEZES (1985) ilustram a intensidade da motivação oferecida à indústria química, a partir do montante de recursos oferecidos para os investimentos necessários ao plano. 
"A expansão da demanda de agrotóxicos no Brasil, nos últimos quinze anos, resultou de uma política oficial de incentivo. Esta política, expressa nos Programas Nacionais de Desenvolvimento (PND's), foi reforçada em 1975, com o lançamento do Programa Nacional de Defensivos Agrícolas (PNDA), quando, entre outras medidas, o governo federal investiu mais de US\$ 200 milhões na implantação e desenvolvimento das indústrias" (PESSANHA \& MENEZES, 1985:2).

Outros fatores apontados pelos autores como estimuladores da expansão no uso dos agrotóxicos no período são:

- o elevado número de aplicações praticadas pelos agricultores desinformados;

- a deficiência do aparato institucional de controle dos produtos;

- a expansão das áreas de monocultura; e ainda

- a insipiência dos instrumentos institucionais voltados à defesa ambiental e dos consumidores, em relação aos aspectos tóxicos ligados aos produtos químicos.

PESSANHA (1982) salienta que em meados da década de 70 os estudos setoriais desenvolvidos no contexto de construção das políticas econômicas de substituição de importações já constatavam que a dependência externa do país no mercado de defensivos era quase que total. Além disso o mercado interno era praticamente controlado por empresas multinacionais

O PNDA induziu um período de importantes mudanças no cenário das indústrias de agrotóxicos no país. Ao início do programa o Brasil contava com cerca de quatorze fábricas de síntese produzindo dezoito tipos diferentes de agrotóxicos (PESSANHA \& MENEZES, 1985:3). Essas indústrias eram basicamente controladas por capital externo e a dependência de importações de agrotóxicos era muito grande.

Os objetivos que inspiraram a construção do PNDA visavam sanar estas dificuldades, através da ampliação da participação nacional no mercado interno. Como meta geral o plano estabelecia a redução da dependência externa, em cinco anos, de $76 \%$ para $50 \%$ do consumo interno. 
Outras metas desenhadas para o período entre 1975 e 1980 foram:

- elevar o consumo nacional para 226 mil toneladas, praticamente triplicando o total consumido no ano de 1994;

- elevar a produção nacional para 123 mil toneladas, representando um aumento de $500 \%$ sobre a produção de 1974 ;

- implantar novas fábricas para síntese de onze produtos no país.

O cumprimento das metas de redução da dependência das importações foi realizado de forma relativamente satisfatória, tendo-se alcançado em 1980 cerca de $50,4 \%$ do consumo aparente; entretanto as metas em relação ao consumo ficaram abaixo das expectativas alimentadas pelo plano (Tabela 16)

Conforme observam PESSANHA \& MENEZES (1985), comparando-se os anos de 1974 e 1980, a produção interna de agrotóxicos elevou-se em 145\%, já o consumo aparente praticamente ficou inalterado.

\section{Tabela 16 - Brasil - Agrotóxicos* - Produção, Importação, Exportação e Consumo Aparente - 1970 - 84 (em toneladas)**}

\begin{tabular}{ccccc}
\hline ANO & PRODUÇÃO & IMPORTAÇÃO & EXPORTAÇÃO & CONSUMO APARENTE \\
\hline 1970 & 9.798 & 18.030 & 100 & 27.728 \\
1971 & 10.823 & 26.535 & 700 & 36.658 \\
1972 & 13.791 & 50.112 & 1.462 & 62.441 \\
1973 & 18.648 & 45.410 & 1.900 & 62.158 \\
1974 & 19.795 & 61.191 & 1.530 & 79.456 \\
1975 & 22.441 & 39.659 & 1.508 & 60.592 \\
1976 & 18.450 & 38.686 & 2.171 & 54.965 \\
1977 & 31.364 & 39.736 & 2.367 & 68.733 \\
1978 & 45.534 & 38.065 & 3.831 & 79.768 \\
1979 & 53.902 & 36.228 & 10.140 & 79.990 \\
1980 & 48.477 & 40.799 & 8.308 & 80.968 \\
1981 & 45.814 & 23.555 & 10.000 & 59.369 \\
1982 & 41.297 & 15.536 & 14.000 & 42.833 \\
1983 & 45.375 & 10.805 & 21.790 & 34.390 \\
1984 & 59.249 & 15.683 & 24.708 & 50.224 \\
\hline * Em concentração técnica **Modificado de PESSANHA \& MENEZES., 1985 &
\end{tabular}

* Em concentração técnica **Modificado de PESSANHA \& MENEZES., 1985

Fonte: Conselho de Desenvolvimento Industrial / Ministério da Indústria e Comércio. 
Em reportagem da revista "Química e Derivados", de julho de 1978, com o título de "Receita Agronômica: nova ameaça ao setor", verifica-se um balanço parcial sobre o PNDA:

"Em agosto de 1975, era lançado o Programa Nacional de Defensivos Agrícolas (PNDA), com o objetivo de eliminar, gradativamente, a dependência brasileira das importações, por meio do fomento à produção nacional. Quase quatro anos depois, apesar de muitas das metas para 1980 já terem sido cumpridas e redimensionadas pela revisão do programa (outubro de 1978), a situação do setor pouco mudou. Num mercado dominado pelas multinacionais, poucas indústrias nacionais puderam ter acesso à tecnologia de síntese dos princípios ativos e sobressair-se" (Química e Derivados, 1979:12).

Como resultados visíveis do PNDA SILVEIRA \& FUTINO (1990) apontam a rápida instalação no país de plantas produtivas de empresas líderes na produção de produtos largamente difundidos. O período de 1974 a 1980 concentrou o maior volume dos investimentos praticados e houve relevância das medidas do PNDA na realização de resultados quanto a internalização da produção de ingredientes ativos. Os investimentos acumulados no período atingiram cerca de US\$200 milhões, o que significava $2 \%$ do montante realizado pela indústria química no período.

Já na década de 80 o efeito das políticas macroeconômicas praticadas resultou em retração das vendas de defensivos. Tal efeito se verifica tanto "pelo lado do clima de instabilidade financeira (afetando as expectativas do investimento direto), quanto pelo efeito sobre a demanda corrente por defensivos, causado pela redução dos volumes disponíveis de crédito de custeio para a agricultura (a partir de 1983, sem subsídios)" (SILVEIRA \& FUTINO, 1990:139).

A citada reportagem da revista "Química e Derivados" aborda ainda a preocupação crescente, no meio empresarial da indústria, com o surgimento das primeiras mudanças na legislação que regulamentava a comercialização dos agrotóxicos, e também com a retração do consumo interno verificada para esses produtos. 
"Com a luta dos agrônomos pela regulamentação do Receituário Agronômico projeto que prevê a comercialização dos produtos mais tóxicos apenas sob receita - $e$ a entrada em vigor de leis institucionalizando o uso de embalagens branca-e-pretas e faixas coloridas de acordo com o grau de toxicidade, os fabricantes de defensivos agrícolas ganharam duas novas preocupações, além das antigas campanhas ecológicas...: a nova legislação de comercialização e o desaquecimento da demanda de defensivos agrícolas, em razão das adversidades climáticas dos dois últimos anos" (Química e Derivados, 1979:12).

Não apenas as adversidades climáticas contribuíram para o desaquecimento da demanda interna de agrotóxicos entre 1975 e 80; outros fatores também influenciaram de forma importante essa retração. A queda em cerca de $19 \%$ da participação dos inseticidas no mercado de agrotóxicos, no período, poderia ser atribuída a adoção do controle integrado que passou a ser aplicado nos plantios de soja e algodão, culturas até então grandes consumidoras de inseticidas (PESSANHA \& MENEZES, 1985).

SILVEIRA \& FUTINO (1990) acentuam ainda a emergência de inovações biotecnológicas (uso de técnicas manejo ecológico de pragas e de controle biológico) como fatores relevantes para a queda do consumo de inseticidas verificada ao final dos anos 70 e início dos anos 80 .

\section{2. A criação da ANDEF}

Criada em 1974 com o objetivo de congregar os interesses da indústria de agrotóxicos, especialmente as multinacionais que constituíam a maior parcela dentre as empresas atuantes no ramo, a Associação Nacional de Defensivos Agrícolas

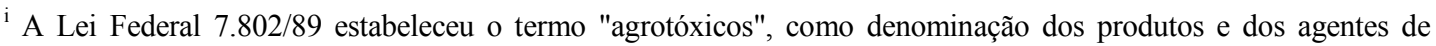
processos físicos, químicos e biológicos, destinados ao controle das pragas e doenças. O emprego deste termo é uma conquista do movimento ambientalista envolvido na luta contra o uso indiscriminado de agrotóxicos no Brasil, conquista esta não reconhecida pela indústria que sempre utilizou o termo "defensivo" para definir seus produtos. Após a aprovação da lei dos agrotóxicos a ANDEF altera sua denominação para "Associação Nacional de Defesa Vegetal".
} 
(ANDEF) realizou esforços concentrados na divulgação de suas estratégias de disseminação do chamado "uso adequado dos defensivos agrícolas", através de campanhas e ações desenhadas em parcerias com os órgãos públicos, buscando neutralizar as ações de seus opositores que desenvolviam esforços na formação de massa crítica, àquela altura já sedimentada, em torno do uso indiscriminado dos agrotóxicos no país e suas danosas conseqüências.

Os argumentos defendidos pelo presidente da Associação Nacional de Defensivos Agrícolas, Sr. Régis Nei Rahal, em depoimento prestado junto à Comissão Parlamentar de Inquérito na Câmara Federal instituída para tratar dos graves problemas decorrentes da contaminação dos alimentos e dos agrotóxicos, retratam em linhas gerais o pensamento defendido pela indústria e seus interlocutores, no debate travado à época em torno do uso de agrotóxicos.

"Eles (os agrotóxicos) compõem o único caminho para viabilizar a agricultura brasileira: evitariam importações de alimentos in natura como prevista para este ano, correspondente a 2 bilhões de dólares.....Evitariam, ainda, a participação dos resultados dos investimentos no valor de milhões de cruzeiros, por parte de agricultores, com insetos, fungos e ervas daninhas...

...Temos de ser realistas, não há outra saída viável para nossa agricultura, senão o uso de defensivos " (Informe Agropecuário , 1979: 150).

Quatro anos após sua criação já se podia verificar alguns resultados colhidos a partir das atividades desenvolvidas pela associação, conforme reportagem publicada na revista "Dirigente Rural", em outubro de 1978:

"...A campanha em torno deste último aspecto (uso adequado), lançada nos Estados de São Paulo, Rio Grande do Sul e Paraná pelas respectivas secretarias de Agricultura, com a colaboração da Andef, movimentou mais de trezentos municípios, os quais receberam 15 mil cartas circulares e 1.600 cursos. Estes, somados a mais de 
quinhentas palestras e reuniões, foram dirigidos a um público diretamente interessado superior a 80 mil pessoas..." (Dirigente Rural, 1978:28).

As iniciativas da ANDEF na promoção do "uso adequado" buscavam também envolver a comunidade técnica, tanto na área agronômica como nos setores de saúde:

"...Empenha-se a Andef na criação de infra-estrutura na área toxicológica. Esta tem a finalidade de levar aos engenheiros agrônomos e a outros profissionais de setores afins os conceitos, características e conseqüências da toxicidade dos defensivos agrícolas existentes no mercado...No âmbito da toxicologia deve-se mencionar a edição pela entidade do livro Tratamento das intoxicações agudas, de autoria dos professores Emílio Astolfi, Waldemar Ferreira de Almeida e Júlia Higa de Londoni" (Dirigente Rural, 1978:28).

As expectativas da indústria, em relação ao papel a ser desempenhado pelo setor público, nas campanhas sobre o uso adequado dos agrotóxicos, encontram-se bem retratadas por um de seus dirigentes, Régis Rahal, em entrevista publicada na revista "Informe Agropecuário" do ano de 1979.

"...Em circunstâncias normais o uso adequado dos defensivos agrícolas é uma tarefa do governo" (Informe Agropecuário, 1979: 151).

Tentando rebater as críticas que já começavam a surgir sobre a idéia do uso adequado como uma simples campanha de vendas, o então presidente da ANDEF destaca na citada reportagem sua visão sobre o papel da área governamental nesta questão. Para ele a responsabilidade pelo uso adequado seria do governo, pois em suas mãos estavam todos os instrumentos, meios e recursos necessários para a institucionalização das campanhas, incluindo: as redes de assistência técnica e defesa sanitária, as estruturas operacionais e ainda o poder coercitivo da ação fiscal..

"...Campanha de uso adequado é uma tarefa educativa, concretizada basicamente por engenheiros agrônomos especialmente treinados, com o objetivo final de levar 
uma mensagem a todos que aplicam, manipulam trasnportam ou armazenam os defensivos agrícolas. Porque, na realidade, trabalham com tóxicos, com veneno."

...O defensivo é uma arma de defesa, não de ataque. Ele foi criado para defender o meio-ambiente, para aumentar a sua produtividade. Para matar insetos. Deve ser uma ajuda à preservação da natureza. Nunca para contaminar riso, para matar pássaros" (Informe Agropecuário, 1979: 151).

A visão do representante da indústria sobre as potencialidades do agricultor brasileiro para absorver toda a complexidade derivada do contato com a tecnologia química pode ser avaliada em outra manifestação constante no artigo da revista Informe agropecuário:

"Com um verdadeiro voto de confiança na capacidade e habilidade do agricultor brasileiro, Régis Rahal afirmou que as três mil formulações comerciais registradas no Ministério da Agricultura, oriundas de 167 princípios ativos, não constituem pontos de confusão para o produtor.

Não existe absolutamente tentativa de engodo ao agricultor. E ele sabe muito bem, ele conhece profundamente, quando necessário, a marca e o princípio ativo que ela carrega. A indústria é obrigada a colocar o princípio ativo nas suas marcas comerciais. Mas hoje, no Brasil, estamos vivendo uma situação muito interessante. A situação do proíba-se. Nunca do evite-se. Precisamos passar para a situação do eduque-se, levar uma mensagem educativa e o governo deve assumir esse papel. $O$ governo está gastando, hoje, alguns milhões de cruzeiros em campanhas institucionais. Perfeito. Mas vamos gastar um pouco também em campanhas educacionais de defensivos agrícolas" (Informe Agropecuário, 1979: 151). 


\section{3. O papel do Crédito Rural no crescimento do mercado}

As mudanças nos padrões de consumo brasileiro de agrotóxicos nos anos 70 foram fortemente influenciadas pelas políticas de crédito agrícola implementadas como forma de subsídios à aquisição dos chamados insumos modernos.

Conforme observa FERRARI (1985), ao início dos anos 70 o Banco do Brasil tornou obrigatório o direcionamento de $15 \%$ do valor dos empréstimos de custeio para a aquisição de agrotóxicos, estimulando assim, de forma institucional, a ampliação do mercado interno de consumo desses produtos.

O perfil das políticas de crédito adotadas em termos de volume disponível de recursos, taxas de juros e forma de amortização dos empréstimos foram muito favoráveis à aquisição desses insumos, especialmente entre 1974 e 1981, período em que a parcela de crédito rural destinada à compra de agrotóxicos aumentou de 5\% para 8\%. em relação ao volume global de crédito de custeio utilizado (Tabela 17).

Tabela 17 - Financiamento concedido pelo Sistema Nacional de Crédito Rural, aos produtores e às cooperativas agrícolas, para o custeio agrícola e a aquisição de agrotóxicos - Brasil - 1974 - 1981

\begin{tabular}{ccc|ccc}
\hline Ano & $\begin{array}{c}\text { Financiamento } \\
\text { Agrícola* }^{*}\end{array}$ & $\begin{array}{c}\text { Financiamento } \\
\text { para Custeio* }\end{array}$ & \multicolumn{3}{|c}{$\begin{array}{c}\text { Aquisição } \\
\text { de agrotóxicos** }\end{array}$} \\
\cline { 2 - 6 } & $\begin{array}{c}\text { Valor (1) } \\
(\text { Cr\$1.000.000) }\end{array}$ & $\begin{array}{c}\text { Valor }(1) \\
(\text { Cr\$1.000.000) }\end{array}$ & $\begin{array}{c}\text { Valor }(1) \\
\text { Cr\$1.000.00 } \\
0)\end{array}$ & $\begin{array}{c}\text { \% em relação ao volume } \\
\text { total de crédito agrícola }\end{array}$ & $\begin{array}{c}\text { \% em relação ao } \\
\text { volume de crédito } \\
\text { para custeio }\end{array}$ \\
\hline 1974 & 12.827 .390 & 6.937 .589 & 339.097 & 2,6 & 4,9 \\
1975 & 18.286 .891 & 8.820 .424 & 482.626 & 2,6 & 5,5 \\
1976 & 18.969 .454 & 9.590 .336 & 711.749 & 3,8 & 7,4 \\
1977 & 18.476 .508 & 9.755 .022 & 656.496 & 3,6 & 6,7 \\
1978 & 17.659 .045 & 9.788 .836 & 651.100 & 3,7 & 6,7 \\
1979 & 21.879 .931 & 13.114 .975 & 913.733 & 4,2 & 7,0 \\
1980 & 23.395 .848 & 14.704 .536 & 1.028 .950 & 4,4 & 7,0 \\
1981 & 21.330 .410 & 13.310 .798 & 1.061 .298 & 5,0 & 8,0 \\
\hline
\end{tabular}

(1) Valores em moeda de 1984 - Foi utilizado o Índice Geral de Preços - Disponibilidade Interna (IGP-DI) Conjuntura Econômica.

* Fonte: Anuário Estatístico do Brasil

** Fonte: FERREIRA et al (1984) 
As culturas de soja, trigo e algodão consumiram mais de $40 \%$ dos valores concedidos de financiamentos aos produtores e às cooperativas para aquisição de agrotóxicos, entre os anos de 1977 e 1981 (Tabela 18).

Tabela 18 - Evolução da participação percentual das principais culturas, no valor total dos financiamentos concedidos aos produtores e às cooperativas para aquisição de agrotóxicos , Brasil , 1977 - 1981

\begin{tabular}{cccccc}
\hline Cultura & \multicolumn{5}{c}{ Ano } \\
\cline { 2 - 6 } & 1977 & 1978 & 1979 & 1980 & 1981 \\
\hline Soja & 35,6 & 33,8 & 37,2 & 26,9 & 26,8 \\
Trigo & 21,8 & 19,7 & 18,5 & 12,0 & 9,4 \\
Algodão & 9,8 & 7,6 & 8,2 & 8,8 & 11,3 \\
Arroz & 9,0 & 7,3 & 5,7 & 5,6 & 7,4 \\
Frutas em geral & 3,6 & 4,9 & 4,7 & 4,9 & 6,8 \\
Cana-de-açúcar & 3,7 & 4,1 & 3,4 & 5,3 & 6,6 \\
Café & 1,7 & 2,2 & 3,6 & 15,2 & 4,8 \\
Demais culturas & 14,8 & 20,4 & 18,7 & 21,3 & 26,9 \\
& & & & & \\
\hline
\end{tabular}

Fonte: modificado de FERREIRA, et alli (1984)

FUTINO \& SILVEIRA (1991) baseados nas demonstrações desenvolvidas por NAIDIN (1985), observam que outro indicador da importância da política de crédito agrícola na aquisição de agrotóxicos entre os anos de 1977 e 1980 pode ainda ser verificado na relação entre a participação do valor do crédito sobre as vendas do setor. Tal relação passa de 54\% em 1977 para 71\% em 1980, e atinge 79\% das vendas já em 1980; ou seja: ao início da década de 80 aproximadamente 3/4 do mercado de agrotóxicos no Brasil era financiado pelo crédito agrícola de custeio.

A configuração da política de concessão de crédito rural vinculado à aquisição de agrotóxicos, ao final da década de 70 , contou com a participação ativa da indústria multinacional de agrotóxicos, através de sua associação - a ANDEF - , desencadeando gestões junto aos órgãos do poder público responsáveis pelo estabelecimento das condições do crédito rural no Brasil.. A manifestação de um de seus dirigentes, à época, em reportagem à revista Dirigente Rural, traduz a medida e os resultados dessa participação. 
"De acordo com o presidente desse organismo, Régis Nei Rahal, ...como resultado das sugestões endereçadas pela Andef, o Banco Central, em maio último, emitiu comunicado às instituições financeiras no sentido de que estimulem a concessão de crédito para a aquisição de defensivos, conjuntamente com outros insumos incluídos no custeio. Ressalta ainda o comunicado que um projeto (para obtenção do crédito de custeio) será julgado insatisfatório se não considerar a necessidade de inclusão (segundo indicações técnicas) de defensivos agrícola" (Dirigente Rural, 1977:23).

FUTINO \& SILVEIRA (1991) apontam duas implicações dessa política nos

padrões de consumo em diferentes cadeias produtivas agrícolas: a) notou-se o estabelecimento de um círculo vicioso pelo aumento do número de pragas e pela rigidez na utilização do crédito, a partir do incremento no uso preventivo de inseticidas e fungicidas; e b) no caso dos herbicidas, a disponibilidade de crédito de custeio estimulou as tomadas de decisão em mudanças tecnológicas da capina mecânica para a química.

\section{4. O incremento do uso e a percepção dos impactos à saúde e ao ambiente}

Uma das graves conseqüências relacionadas ao uso de agrotóxicos são os efeitos à saúde das populações expostas direta e indiretamente a esses insumos. A Organização Mundial da Saúde - O.M.S (1990) estimou que o número de pessoas expostas a esse risco, em atividades agrícolas, girava em torno de 500 milhões. Os casos estimados de intoxicações agudas não intencionais atingiriam 1 milhão de ocorrências, sendo que cerca de $70 \%$ destas estariam relacionadas a atividades de trabalho.

Mas as intoxicações agudas representam apenas uma parte dos danos causados à saúde humana. Considerando-se ainda os casos de intoxicações sub-crônicas e crônicas podemos verificar que as dimensões do problema assumem ainda proporções maiores. Os casos de dermatoses originadas pela exposição a agrotóxicos foram estimados em 
700.000 por ano; os diagnósticos de câncer relacionados a essas exposições atingiriam cerca de 37.000 casos anuais; e os efeitos crônicos que resultam em seqüelas neurocomportamentais estariam em torno de 25.000 casos anuais.

Grande parte das estimativas sobre consumo de agrotóxicos e efeitos à saúde humana apontam para a gravidade do problema de forma especial nos países do terceiro mundo; e nesta perspectiva a situação do Brasil configura-se como uma das mais preocupantes. A associação entre o alto consumo e o completo despreparo para a utilização da tecnologia química, nas condições atuais da agricultura no país, potencializa os danos que começam a ser desenhados a partir da exposição ocupacional, expande-se nas dimensões da exposição ambiental e finalmente configura-se como grave problemas de saúde pública, na medida em que podem atingir a população em geral pela contaminação dos alimentos e dos mananciais de abastecimento.

A ausência de dados oficiais sistemáticos sobre as ocorrências de intoxicações envolvendo trabalhadores rurais expostos aos agrotóxicos no Brasil não invalida o significado das estimativas possíveis de serem exercitadas com base em dados primários sobre a população exposta ao risco e ainda sobre as quantidades de produtos consumidos no meio rural.

Uma das poucas fontes de informações sobre notificações de casos de intoxicações por agentes químicos existentes no Brasil é o Sistema de Informações TóxicoFarmacológicas (SINITOX), do Ministério da Saúde. Este serviço, cuja coordenação é feita através da Fundação Oswaldo Cruz (FIOCRUZ/MS), tem a função de consolidar informações originadas em vários centros de atendimentos de vários estados do país.

Os dados relativos ao ano de 1998 demonstram que dentre os casos registrados naquele ano, de intoxicações humanas, o agente tóxico definido como "pesticidas agropecuários" foi responsável por 6,64\% dos casos, representando a sexta principal causa de intoxicações. Se considerarmos os dados relativos a pesticidas agropecuários somados a outras classes de agentes tóxicos correlacionadas (pesticidas domésticos, 
raticidas, e domissanitários) o percentual de casos registrados resulta em 13,66\%, passando ao terceiro lugar dentre as causas de ocorrências.

A distribuição percentual dos casos relativos ao ano de 1998, de intoxicação humana, segundo o agente tóxico é apresentada no Figura 8, a seguir.

Figura 8 - Distribuição percentual dos casos registrados no SINITOX, de intoxicação humana, por agente tóxico - Brasil - 1998

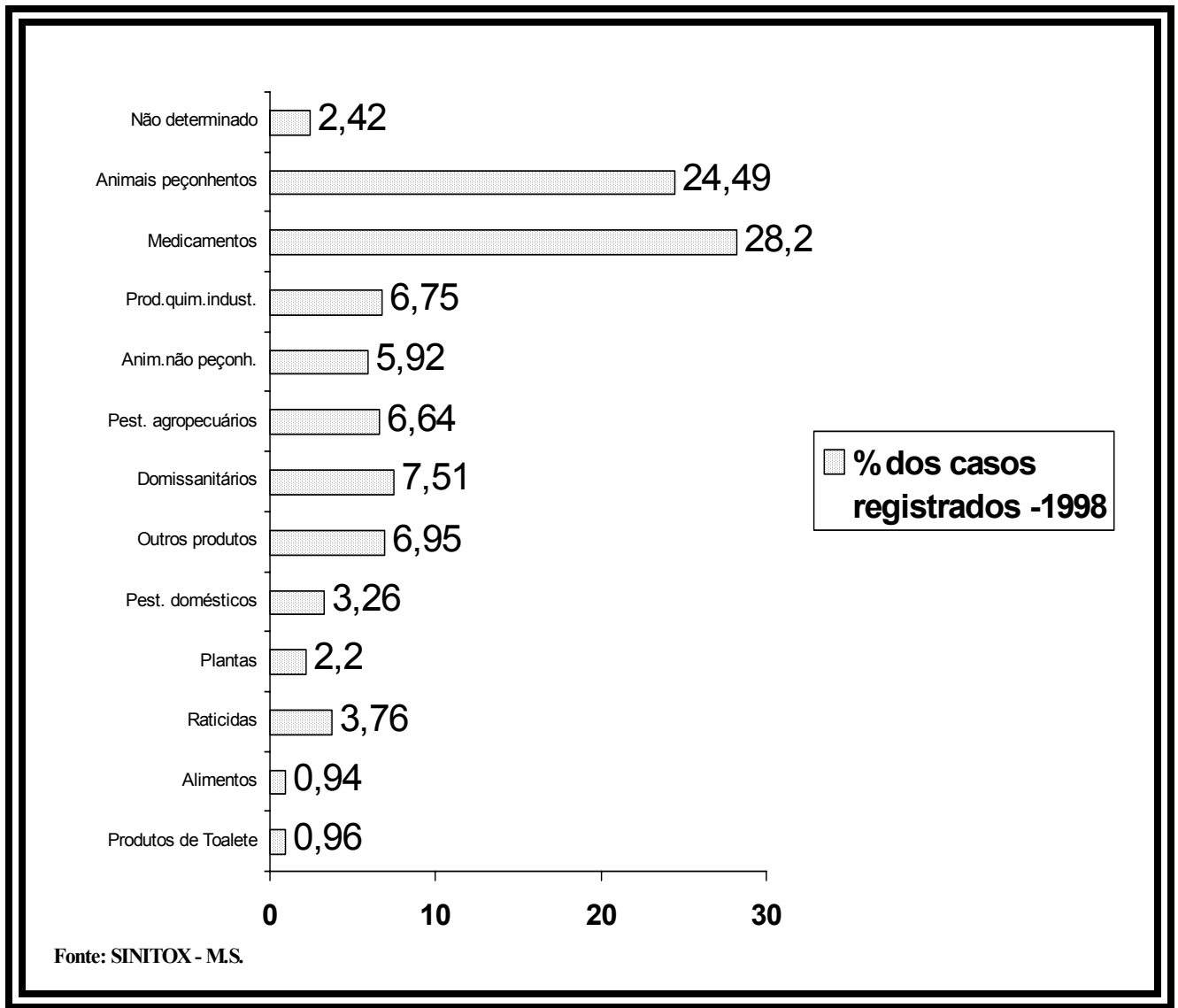

Tomando-se por base as informações notificadas ao SINITOX, as dimensões dos problemas de saúde humana relacionados à exposição aos agrotóxicos, no Brasil, aparecem em escala bem diferente daquelas apresentadas pelas estimativas da Organização Mundial da Saúde. Os casos notificados tendo os pesticidas como agente causal das intoxicações atingem 5.268 registros em 1998, sendo superados pelos casos notificados relacionados a medicamentos, animais peçonhentos e outros agentes. 
Muitas vezes estes dados são apresentados como demonstração de que a dimensão do problema decorrente da exposição aos agrotóxicos não seria mais importante do que aqueles oriundos da exposição a outros tipos de agentes químicos. Entretanto é preciso salientar que os casos registrados pelo sistema são somente aqueles que chegam aos serviços de saúde através das redes de atendimento primário e secundário, e neste contexto são diagnosticados tendo como causa os agrotóxicos.

Ocorre entretanto que a maioria dos serviços de saúde apresenta limitação na capacidade de diagnosticar intoxicações relacionadas a agrotóxicos. O SINITOX consolida informações dos CCI's - Centros de Controle de Intoxicações, os quais representam uma rede de retaguarda e suporte aos serviços de saúde em geral no encaminhamento dos casos agudos de intoxicação. Assim sendo, muitos casos subagudos ou crônicos podem ficar fora do sistema de notificação, mascarando desta forma a situação real de gravidade decorrente da exposição humana a esses agentes químicos.

Os casos de intoxicação registrados no SINITOX, relacionados à exposição a agentes químicos nas atividades de trabalho (exposição profissional) já mostram um cenário diferente de importância dos agrotóxicos como agentes causadores das intoxicações, onde os pesticidas surgem como responsáveis por $25,1 \%$ dos casos notificados.

A evolução dos casos registrados pelo SINITOX entre os anos de 1993 e 1998, por exposição geral ou profissional, e o peso percentual dos eventos relacionados aos pesticidas agropecuários são mostrados na tabela 19. 
Tabela 19 - Evolução dos casos registrados pelo SINITOX, de intoxicação humana, por agente causal geral e por agrotóxicos, em situações de exposição geral e exposição ocupacional - Brasil - 1999

\begin{tabular}{|c|c|c|c|c|c|c|c|c|c|c|c|}
\hline \multirow[t]{3}{*}{ Causa } & \multirow{3}{*}{$\begin{array}{l}\text { Agente } \\
\text { Tóxico }\end{array}$} & \multicolumn{10}{|c|}{ Ano } \\
\hline & & \multicolumn{2}{|c|}{93} & \multicolumn{2}{|c|}{94} & \multicolumn{2}{|c|}{96} & \multicolumn{2}{|c|}{97} & \multicolumn{2}{|c|}{$\begin{array}{l}98 \\
\end{array}$} \\
\hline & & $\begin{array}{l}\mathrm{n}^{\mathrm{o}} \mathrm{de} \\
\text { casos }\end{array}$ & $\begin{array}{l}\% \text { do } \\
\text { total }\end{array}$ & $\begin{array}{l}\mathrm{n}^{\mathrm{o}} \mathrm{de} \\
\text { casos }\end{array}$ & $\begin{array}{l}\% \text { do } \\
\text { total }\end{array}$ & $\begin{array}{l}\mathrm{n}^{\circ} \mathrm{de} \\
\text { casos }\end{array}$ & $\begin{array}{l}\% \text { do } \\
\text { total }\end{array}$ & $\begin{array}{l}\mathrm{n}^{\mathrm{o}} \mathrm{de} \\
\text { casos }\end{array}$ & $\begin{array}{l}\% \text { do } \\
\text { total }\end{array}$ & $\begin{array}{l}\mathrm{n}^{\mathrm{o}} \mathrm{de} \\
\text { casos }\end{array}$ & $\begin{array}{l}\% \text { do } \\
\text { total }\end{array}$ \\
\hline \multirow[t]{2}{*}{ Geral } & Total & 46967 & & 44859 & & 64690 & & 74784 & & 79366 & \\
\hline & Agrotóxicos & 3418 & $(7,2)$ & 3740 & $(8,3)$ & 4829 & $(7,4)$ & 5199 & $(6,9)$ & 5268 & $(6,6)$ \\
\hline \multirow[t]{2}{*}{ Profissional } & Total & 3735 & & 3858 & & 5948 & & 7099 & & 6628 & \\
\hline & Agrotóxicos & 779 & $(20,8)$ & 753 & $(19,5)$ & 1347 & $(22,6)$ & 1433 & $(20,1)$ & 1663 & $(25,1)$ \\
\hline
\end{tabular}

Fonte: SINITOX - 1998

Avaliando-se as informações sobre o número de registros de casos de intoxicação que evoluíram a óbito, dentro do sistema de notificação do SINITOX, verifica-se que os casos relacionados a agrotóxicos somaram 181 ocorrências em 1998, representando $40,2 \%$ destes casos em relação aos demais agentes tóxicos, mostrando a gravidade do evento (Figura 9).

Figura 9 - Distribuição percentual dos casos registrados, de intoxicações humanas que evoluíram a óbito, e agente tóxico - Brasil - 1999

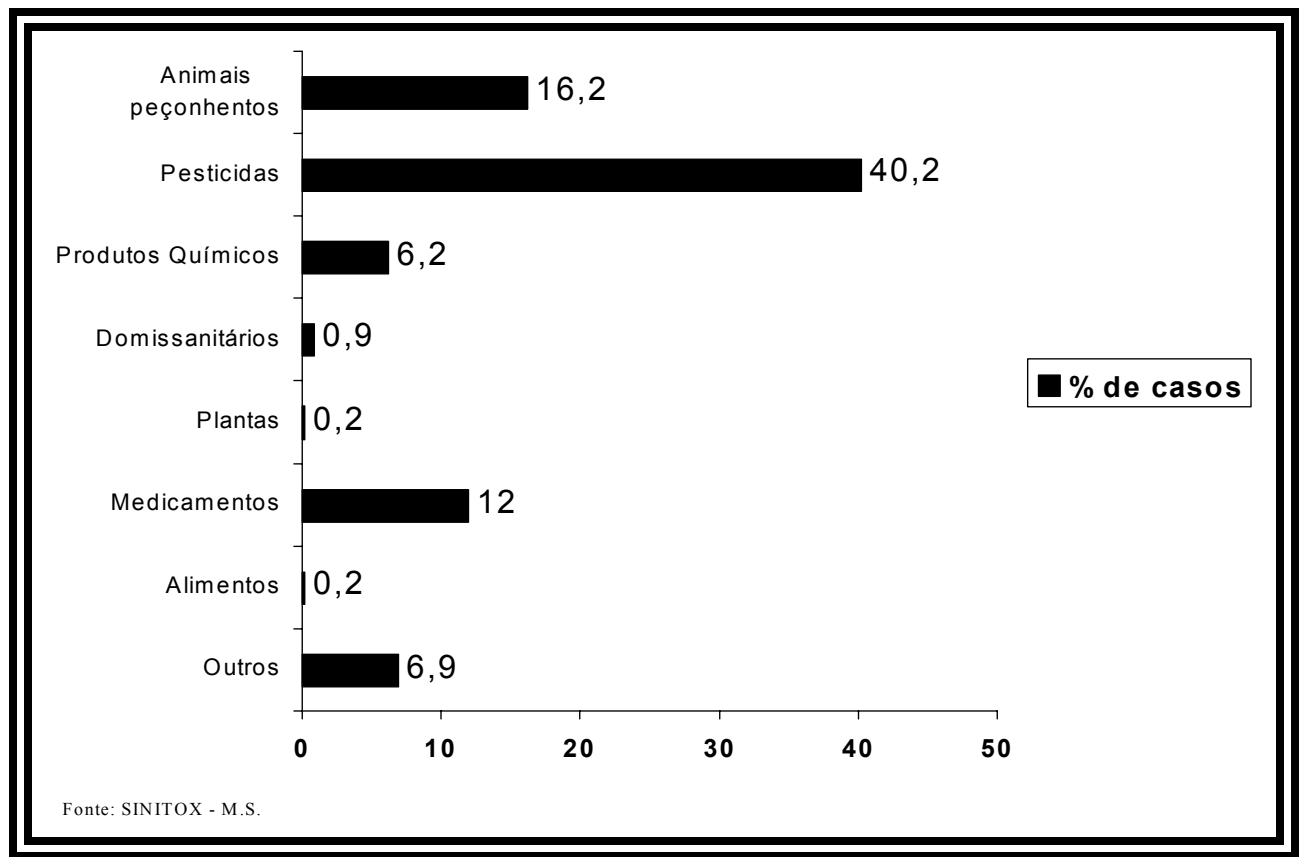


São diversos os fatores que contribuem para o agravamento dos riscos ocupacionais relacionados ao uso dos agrotóxicos. Alguns deles estão ligados diretamente ao produto e suas características, tais como: tipo de formulação, método de aplicação, grau de toxicidade.

Outros estão associados ao contexto mais amplo do uso e podem ser identificados como: dificuldade de acesso à orientação técnica; carência de informações sobre técnicas de segurança no trabalho; precariedade dos equipamentos e máquinas; pouca disponibilidade de equipamentos de proteção; condições climáticas inadequadas; longas jornadas de trabalho potencializando os períodos de exposição; não observação de medidas higiênicas após a exposição; precariedade das condições sanitárias oferecidas nos locais de trabalho; condições orgânicas do trabalhador exposto, etc.

Não obstante a complexidade de fatores que contribuem para definir o padrão de segurança para o uso dos agrotóxicos no campo é possível constatar que um dos pontos de grande importância diz respeito às formas de regular o acesso dessa tecnologia de risco. O conceito de que os riscos relacionados a substâncias químicas nos locais de trabalho são diretamente proporcionais à toxicidade do produto e às condições de exposição também é válido para o caso dos agrotóxicos no campo. Apesar da inexistência de dados precisos sobre as quantidades de agrotóxicos utilizadas no país, ao longo dos últimos anos, pode-se observar uma tendência de acompanhamento no crescimento dos índices de intoxicação por agrotóxicos, na medida em que os valores de vendas destes produtos também crescem (Figura 10) 
Figura 10 - Evolução dos casos de intoxicação humana por agrotóxicos registrados pelo SINITOX* e das vendas de agrotóxicos** nos anos de 1992 a 1998

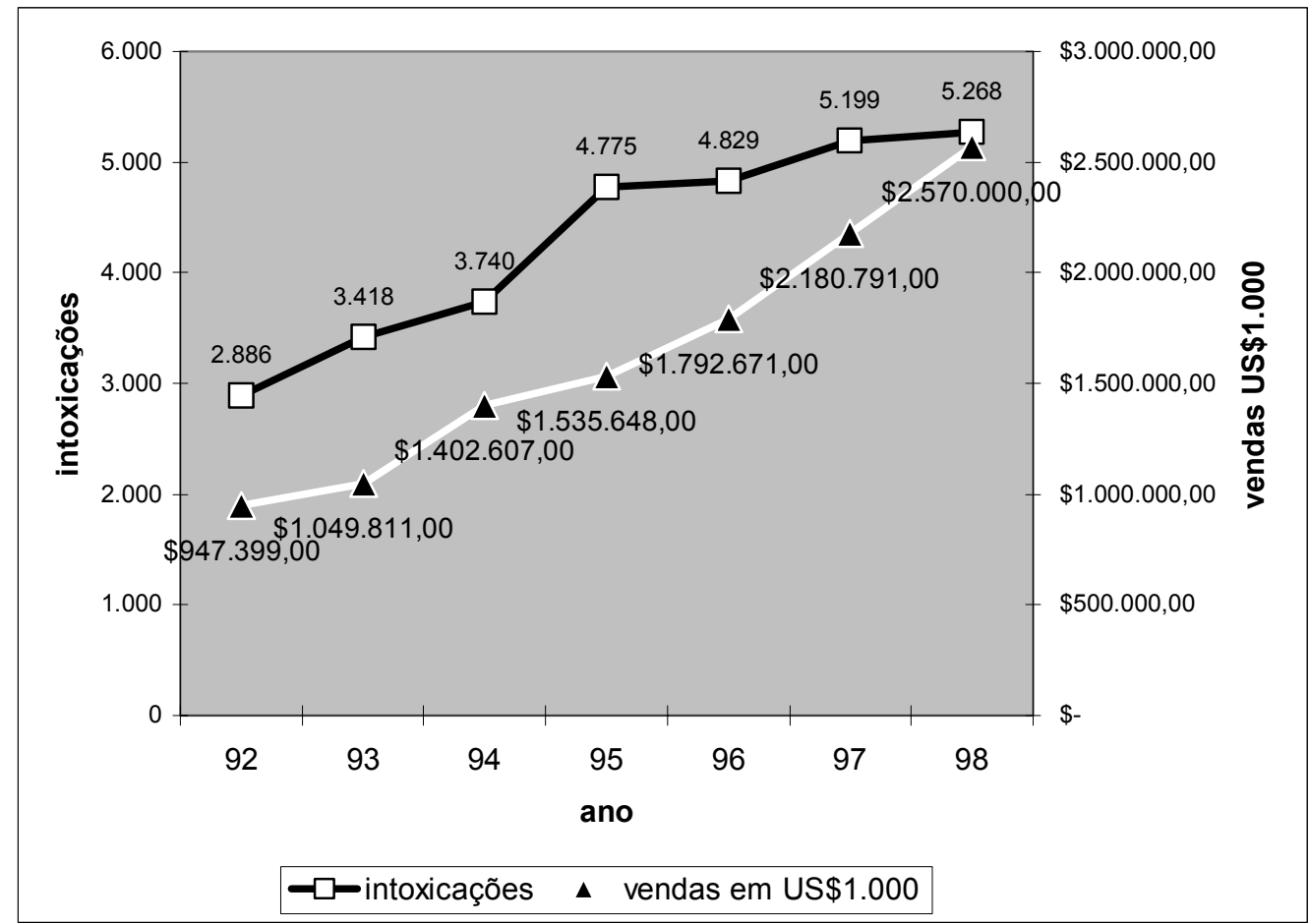

Fonte: * Sistema Nacional de Informações Tóxico-farmacológicas - SINITOX - Ministério da Saúde ** Sindicato Nacional da Indústria de Defensivos Agrícolas - SINDAG

Inseridos na categoria de substâncias químicas denominadas como agrotóxicos podemos encontrar uma vasta quantidade de produtos de diversas classes e grupos químicos. Entretanto, um ponto comum caracteriza todos os componentes dessa categoria: constituem-se como biocidas ativos, podendo representar danos potenciais para todos os organismos vivos.

As formas de se avaliar o potencial de toxicidade e o comportamento dessas substâncias no ambiente, passam por estudos de fatores tais como: estrutura química, solubilidade em água e em gorduras, volatilidade, estabilidade e persistência. No entanto, conforme aponta EDWARDS (1993) esses dados ainda são limitados pois oferecem principalmente informações sobre a toxicidade aguda para poucas espécies selecionadas. Para a grande maioria dos seres vivos expostos aos agrotóxicos não existe qualquer informação sobre o grau de toxicidade que essas substâncias apresentam para essas formas de vida. 
Os efeitos indiretos da presença dos agrotóxicos no ambiente podem ser tão importantes quanto os efeitos diretos da toxicidade. Os efeitos crônicos da contaminação podem interferir em fatores tais como: expectativa de vida, crescimento, fisiologia, comportamento e reprodução dos seres vivos expostos. Dentre os efeitos indesejáveis pode-se destacar dois deles que representam uma contradição no uso dessa tecnologia para o combate às pragas e doenças na agricultura, quais sejam: os efeitos tóxicos sobre os inimigos naturais das pragas e doenças, e o desenvolvimento de mecanismos de resistência das pragas e doenças em relação ao efeito tóxico das moléculas de agrotóxicos em uso.

Em estudo da Organização Pan-americana de Saúde (1993) são citados vários casos e exemplos de contaminação de águas, solo e ar em numerosos países, como resultado de contínuas exposições a agrotóxicos, entretanto há o reconhecimento de que com os dados disponíveis não é possível avaliar toda a magnitude do problema.

A preocupação crescente com as possibilidades reais de comprometimento dos mananciais e fontes de abastecimento de água, como conseqüência da contaminação pelo uso de agrotóxicos nas lavouras, pode ser detectada pelos dados apresentados pela Agência de Proteção Ambiental dos Estados Unidos. Os resultados desses estudos indicam que aproximadamente $10,4 \%$ dos 94.600 reservatórios comunitários de água e $4,2 \%$ dos 10.500 .000 poços domésticos da zona rural apresentavam níveis detectáveis de agrotóxicos. Dentre os casos detectáveis cerca de 0,6\% apresentavam índices de contaminação acima dos permitidos pela legislação atual da EPA/ USA.

Outro ponto importante de impacto ambiental relacionado ao uso de agrotóxicos diz respeito ao problema da descontaminação e destinação final das embalagens utilizadas no campo.

No Brasil este problema encontrava-se, até julho de 2000, totalmente distante de solução abrangente. Algumas iniciativas foram realizadas em comunidades que buscavam algum tipo de solução cooperada, mas todas elas foram basicamente fruto de voluntarismo dos consumidores, e o papel e a responsabilidade das indústrias que 
comercializam estes produtos, e dos órgãos governamentais responsáveis pela regulamentação e fiscalização desse setor ficava restrito a campanhas de incentivo às iniciativas fragmentadas dos consumidores, ou ainda, como regra mais comum, caracterizaram-se pela omissão.

Um exemplo de tais iniciativas está sendo tomada no Estado do Rio Grande do Sul, na construção de Centrais Regionais de Embalagens, através de consórcios entre fabricantes (ANDEF), municípios, associações de engenheiros agrônomos e universidades. O objetivo é a montagem de um esquema logístico que permita o recebimento das embalagens tríplice lavadas atividades de campanhas de conscientização e esclarecimento aos usuários (PORTO, 2000).

Em Lajeado, município do Rio Grande do Sul, a Promotoria de Defesa Comunitária da Comarca já instaurou inquérito civil para investigar o problema e encontrar soluções. Foram realizadas várias reuniões com fornecedores de agrotóxicos na região, os quais, num primeiro momento, mostraram-se recalcitrantes em assumir o ônus do recolhimento, sob a alegação de que tal encargo seria do Poder Público. Posteriormente, mudaram suas posições, a partir do conhecimento dos preceitos legais sobre a matéria, firmando então o compromisso de recolhimento das embalagens, e transporte até uma central de reciclagem (PORTO, 2000).

Outro exemplo dessas tentativas se deu na campanha desenvolvida no estado do Paraná, e divulgada através de reportagem no "Suplemento Agrícola" do jornal "O Estado de São Paulo", em maio de 1999.

O Estado do Paraná passou a operar, a partir de julho de 1999, 13 unidades de recebimento e triagem de embalagens de agrotóxicos. A iniciativa é parte de um

\footnotetext{
${ }^{\text {i }}$ Tríplice lavagem é o nome dado ao processo pelo qual se realiza a lavagem das embalagens por no mínimo três vezes em água limpa, depois que o produto é totalmente utilizado e a embalagem é esvaziada. A água da lavagem deve ser entornada no próprio tanque do pulverizador usado para a aplicação, de maneira que haja aproveitamento total do agrotóxico. Segundo os órgãos envolvidos no programa, o processo de tríplice lavagem, aprovado pela Associação Brasileira de Normas Técnicas, reduz a contaminação da embalagem para níveis mínimos.
} 
programa da Secretaria de Estado do Meio Ambiente em parceria com a ANDEF Associação Nacional de Defesa Vegetal, denominado "Programa Terra Limpa", o qual tem como objetivo evitar que as embalagens de agrotóxicos contaminem o ambiente.

O programa contou com uma fase piloto em 1998, a partir da experiência desenvolvida em dois municípios (Palotina e Santa Terezinha do Itaipu), e em 1999 passa a desenvolver a fase de expansão para 60 unidades projetadas em todo o estado.

O cumprimento da etapa da tríplice lavagem caracteriza-se como um passo fundamental no esquema do programa, de forma a propiciar o seguimento do trabalho que prevê a reciclagem controlada da embalagem, a partir do reaproveitamento de materiais como vidro, plástico e metal por determinadas indústrias. E é exatamente neste ponto que reside toda a fragilidade do programa, uma vez que na prática não é possível fazer a distinção "visual" entre uma embalagem que sofreu a "tríplice lavagem" de outra ainda contaminada. Assim, toda a logística estabelecida para o recolhimento, transporte e eventual destinação para reciclagem das embalagens, tratando o material como "resíduo não-tóxico", se mostra inapropriada para a prevenção de problemas de contaminação ambiental e humana.

A produção de embalagens contaminadas pelos agrotóxicos no estado do Paraná, em seus diferentes tipos de ingredientes ativos, formulações e classes toxicológicas, chega a atingir em média a quantidade de 14 milhões de unidades por ano, o que, segundo dados da Superintendência de Desenvolvimento de Recursos Hídricos e Saneamento Ambiental, equivale à cerca de 2 mil toneladas de embalagens por ano (SUDERHSA, 1998:1).

Até junho de 2000 a legislação que regulava o uso de agrotóxicos previa que as embalagens contaminadas deveriam ser enterradas, prática esta utilizada por grande parte dos agricultores até então. Entretanto a resistência a esse método tem sido crescente em vista da saturação e da escassez de espaços reservados para tal uso. A resultante desta resistência pode ser constatada pelo número significativo de embalagens de agrotóxicos que são jogadas dentro de rios, abandonadas nas lavouras, 
queimadas a céu aberto, enterradas de forma inadequada, ou, na situação mais crítica, reutilizadas para acondicionamento de alimentos e água, conforme relatam os fiscais da defesa agropecuária do Estado do Paraná

O Estado de São Paulo também conta com um programa concebido nessa mesma linha, ainda incipiente, mas que está sendo incrementado pela ANDEF, em parceria com prefeituras e órgãos locais de algumas cidades do interior do estado (Guariba e Piracicaba - em funcionamento; Limeira, Paraguaçu, Biritiba Mirim, Taquarivaí, Holambra, Bebedouro, Ituverava - planejadas para funcionamento a partir de 1999; e Araras, Tupã, Ourinhos, e Presidente Prudente - previstas para 2000; segundo dados divulgados pela ANDEF

Um passo importante na tentativa de resolução dos problemas sobre destinação final das embalagens de agrotóxicos utilizados no campo, foi dado recentemente, a partir da aprovação da Lei Federal N 9.974 , de 06 de junho de 2000, a qual altera a chamada "Lei dos agrotóxicos" (Lei Nº7.802/89) acrescentando importantes aspectos relativos ao problema da destinação correta das embalagens vazias de agrotóxicos.

"...os usuários de agrotóxicos, seus componentes e afins deverão efetuar a devolução das embalagens vazias dos produtos aos estabelecimentos comerciais em que foram adquiridos, de acordo com as instruções previstas nas respectivas bulas, no prazo de até um ano, contado da data de compra, ou prazo superior, se autorizado pelo órgão registrante, podendo a devolução ser intermediada por postos ou centros de recolhimento, desde que autorizados e fiscalizados pelo órgão competente" (Lei No 9.974/2000).

Esta nova disposição legal atribui claramente ao fornecedor de agrotóxico (comerciante, importador e fabricante) a obrigação em dar destinação adequada às

\footnotetext{
${ }^{\text {i }}$ Comunicação verbal concedida pelo Eng $^{\circ}$ Agr $^{\circ}$ Reinaldo Skalisz, Secretaria de Agricultura do Estado do Paraná, em 8 de agosto de 2000

ii ANDEF - Associação Nacional de Defesa Vegetal, http://www.andef.com.br/segutex6.htm , acesso 26.05.99
} 
embalagens vazias dos agrotóxicos, atendendo assim ao princípio do poluidor-pagador ou princípio da responsabilidade

Outro ponto importante de avanço em relação a esta nova legislação contemplando a questão das embalagens vazias de agrotóxicos assenta-se no fato de que com estas novas disposições fica bem caracterizado o papel do poder público, o qual seja: o de "fiscalizador", enquanto que a função de "executor" estaria a cargo dos agentes privados envolvidos.

Isto de certa forma determina a necessidade de um novo rumo ao modelo de solução que vem sendo estimulado pelos representantes das indústrias, os quais atuam no fomento de projetos de recolhimento e destinação de embalagens, onde quase sempre o poder público arca com os custos (recolhimento das embalagens, disponibilização de área para as unidades de recebimento, etc) e a ação privada fica restrita à colaboração nas campanhas educativas, baseadas na "tríplice lavagem".

PORTO (2000) expõe com clareza a questão da improbidade administrativa que pode ser deduzida da ação pública que executa o patrocínio de atividades que competem a entidades privadas.

"...Diante deste princípio e de todos os dispositivos legais antes transcritos, não se recomenda venha o Município a assumir os encargos de coleta, transporte $e$ destinação final de resíduos perigosos, utilizando recursos públicos no patrocínio de atividades que, por lei, competem a entidades privadas.

Os agentes públicos que assim agem podem estar incorrendo em atos de improbidade administrativa causadores de lesão ao erário municipal, porquanto ensejam perda patrimonial do Município e simultâneo enriquecimento ilícito dos

\footnotetext{
${ }^{\text {i }}$ Segundo Édis Milaré, “assenta-se este princípio na vocação redistributiva do Direito Ambiental e se inspira na teoria econômica de que os custos sociais externos que acompanham o processo produtivo (v.g., o custo resultante dos danos ambientais) devem ser internalizados, vale dizer, que os agentes econômicos devem levá-los em conta ao elaborar os custos de produção e, conseqüentemente, assumi-los. Este princípio - escreve Prieur - visa a imputar ao poluidor o custo social da poluição por ele gerada" (in Direito do Ambiente, Ed. RT, ano 2000, pág. 100).
} 
responsáveis privados pela atividade, como previsto no art. 10, XII, da Lei 8.429/92 (Lei de Improbidade Administrativa), enquadramento que é punido com o ressarcimento integral do dano, perda da função pública, suspensão dos direitos políticos de 5 a 8 anos, pagamento de multa de até duas vezes o valor do dano e proibição de contratar com o Poder Público ou de receber incentivos fiscais ou creditícios pelo prazo de cinco anos" (PORTO, 2000).

Mas o problema das embalagens vazias de agrotóxicos é apenas um dos vários pontos de preocupação geral sobre os resíduos provocados pelo uso desses insumos. A atenção na questão dos resíduos também está centrada nas possibilidades de ocorrências nos alimentos e nas águas de abastecimento.

$\mathrm{O}$ incremento dos problemas relacionados aos agrotóxicos se verificam nos âmbitos ocupacionais, ambientais e de saúde pública; e a crescente conscientização sobre estes aspectos pressionam a tomada de decisão no estabelecimento de mecanismos que possam eliminar, ou controlar e mitigar tais problemas.

Também no campo internacional são várias as experiências desenvolvidas no sentido da redução dos riscos relacionados aos agrotóxicos, em decorrência da crescente percepção quanto aos impactos proporcionados pelos agrotóxicos. Tais iniciativas podem ser observadas a partir do estudo publicado pela OECD, no ano de 1996, dedicado a investigar as estratégias adotas por diversos países na redução dos riscos decorrentes do uso de agrotóxicos (OECD, 1996).

O relatório descreve as atividades de redução de riscos dos pesticidas levadas a efeito em 20 países da OECD, na Comissão Européia e em oito países ligados à FAO, mas não pertencentes à OECD.

A pesquisa foi conduzida entre os anos de 1994-95, abordando exclusivamente os agrotóxicos utilizados em atividades de proteção de plantas (agricultura, horticultura e atividades florestais). 
Nos últimos 10 anos, os países da OECD e da FAO iniciaram uma ampla variedade de atividades para redução dos riscos associados ao uso de agrotóxicos. Tais atividades agregaram uma nova dimensão na definição das políticas e programas relacionados aos agrotóxicos.

No passado as atividades de avaliação e manejo dos riscos eram desenvolvidas de forma individual, para cada produto. Atualmente a tendência verificada é a de que os programas busquem a redução dos riscos no uso geral dos agrotóxicos.

As estratégias de atuação também foram modificadas. Os esforços antes concentrados basicamente em políticas e medidas legislativas e de regulação passam a buscar abordagens de trabalho cooperativo e de parcerias entre os atores envolvidos. Tais mudanças começam a propiciar a ampliação dos métodos e dos resultados dos programas nacionais e criam novas oportunidades para a redução dos riscos.

As razões gerais apontadas pelos países da OECD, como motivadoras para dar início a atividades de redução dos riscos dos agrotóxicos foram as seguintes:

- problemas nas áreas de saúde ou ambiente relacionados ao uso de agrotóxicos;

- preocupações gerais quanto a dependência da agricultura no uso maciço de produtos químicos;

- nova legislação incorporando metas ambientais nas políticas e práticas para a agricultura

Como questões específicas os aspectos levantados foram:

- problemas como o desenvolvimento de resistência das pragas aos agrotóxicos, danos sobre as culturas onde se utilizam herbicidas e contaminação das fontes de água;

- preocupações sobre os riscos aos usuários, à população em geral e ao ambiente; 
- preocupações quanto ao incremento no uso de agrotóxicos que tem acompanhado o processo de intensificação da agricultura, e sobre o desenvolvimento de novos produtos que são altamente ativos biologicamente;

- atendimento aos acordos internacionais para redução das emissões químicas em lagos e oceanos, e aos limites de países importadores quanto aos resíduos de agrotóxicos em alimentos.

- interesse em acompanhar o modelo de redução de uso de agrotóxicos adotados em alguns países.

A pesquisa também mostrou que como ponto de partida para as atividades de redução de riscos os países utilizaram os programas já existentes nas áreas de registro de agrotóxicos, pesquisa e extensão rural.

Muitas destas atividades partilhavam uma característica chave: o envolvimento dos produtores rurais desde o início dos projetos, o que as diferenciavam das abordagens dos regulamentos tradicionais.

As estratégias dos diversos países para a redução dos riscos diferem em três principais áreas:

- Objetivos: alguns visam a redução das quantidades totais de uso, outros acreditam que a redução do uso não significa necessariamente a redução dos riscos (por exemplo: uso de menores quantidades de produtos mais tóxicos). Tais países buscam então metas como : minimizar o uso, reduzir a dependência, ou incrementar as práticas de MIP (Manejo Integrado de Pragas).

- Estrutura: alguns países iniciam programas nacionais, outros fazem projetos ad hoc a partir de programas já existentes nas áreas de agricultura e agrotóxicos. 
- Implementação: alguns países acreditam que a participação obrigatória dos agricultores leva ao sucesso, outros ao contrário acreditam no sucesso da participação voluntária. Entre estes existem experiências combinadas associando medidas obrigatórias e participativas.

Entretanto não se identificou uma abordagem específica como de maior sucesso; ao contrário, diferentes estratégias funcionaram bem em diferentes países.

A pesquisa confirmou que o processo de registro dos agrotóxicos foi e continua sendo o fundamento das atividades de manejo dos riscos em todos os países da OECD.

Os processos de registro resultam em 3 situações gerais possíveis:

- produtos cujo risco foi considerado aceitável, à luz dos conhecimentos atuais, podem ser registrados. Rotulagem obrigatória contendo indicações e instruções de uso, e medidas de segurança, complementam o processo;

- produtos considerados inseguros não são registrados, ou apresentam uso restrito. Tais restrições, que permitem apenas o uso sob determinadas situações contando com pessoal especializado, devem constar dos rótulos dos produtos;

- produtos registrados que são posteriormente considerados inseguros, com base em novos conhecimentos, tornam-se restritos ou banidos, tendo seus registros modificados ou cancelados.

Alguns países descreveram novas medidas iniciadas para melhorar a efetividade e eficiência de seus programas, enquanto outros relataram o início de atividades de reavaliação do registro de produtos mais antigos. Tais atividades têm sido prioritárias em vários países, na medida em que o conhecimento de possíveis efeitos adversos têm sido bastante incrementado nas últimas duas décadas. Dessa forma vários países passam a instituir programas contínuos de reavaliação de registros.

Houve uma concordância geral quanto ao sucesso dos programas de registro, embora estes possam ser lentos e demandantes de recursos intensivos. Para enfrentar 
os problemas identificados no processo, várias iniciativas tem sido levadas a efeito, tais como:

- exigência de uso de ingredientes inertes não-tóxicos ou de baixa toxicidade;

- redução das exigências para registro de produtos biológicos de baixo risco;

- estabelecimento de programas de substituição de produtos antigos que superam os níveis de riscos estabelecidos para a saúde e o ambiente, por novas formulações registradas para as mesmas indicações de uso (Suécia e Noruega). Na Suécia há também a possibilidade de negar registro para produtos indicados para controles que já contam com medidas não-químicas que apresentam igual efetividade de controle;

- implementação de programas que priorizam a revisão de processos de produtos mais seguros que outros já no mercado, com mesma indicação de uso (EUA);

- adoção de novos critérios mais restritos para a aprovação de registros, reduzindo grandemente o número de produtos. (Áustria, a partir de 1991);

- desenvolvimento de novos sistemas de classificação para servir de base para a redução ou eliminação de produtos de alto risco, e para a identificação de produtos de baixo risco usados em áreas públicas, especialmente em florestas (província canadense de British Columbia);

A Alemanha pode fazer uso de uma regulamentação aprovada em 1971, que permite a expressa restrição ou banimento de um produto, sem ter que provar o risco ou enfrentar um caso no judiciário. Atualmente, colocando em prática tal regulamento, o parlamento alemão baniu 44 princípios ativos considerados de alto risco.

A Suécia e a Finlândia mantém programas gradativos de banimento de produtos identificados como de alto risco, mas que são difíceis de terem seus registros cancelados, tendo em vista a inexistência de opões alternativas. 
Os países da OECD têm incrementado e expandido seus programas de segurança para os trabalhadores, os quais são reconhecidos como suas principais e mais efetivas ferramentas de redução dos riscos.

Novos programas foram identificados nas áreas de :

- educação e capacitação de usuários de agrotóxicos:

- certificação de fornecedores e distribuidores;

- difusão de informações sobre segurança aos usuários;

- melhoria das rotulagens;

- aperfeiçoamento da legislação relativa a segurança do trabalhador rural;

- desenvolvimento de formulações e embalagens mais seguras;

- destinação apropriada para descarte de embalagens e sobras de produtos.

A Austrália vem desenvolvendo cursos de capacitação para agricultores usuários de agrotóxicos, com foco nas questões de manejo seguro, desenvolvidos em conjunto com os programas de extensão em manejo econômico de pragas e doenças. Tais cursos são normalmente desenvolvidos pelas escolas de agricultura e desenvolvidos em conjunto com órgãos públicos ligados a agricultura, organizações de produtores e indústria química.

O Canadá completou em 1995 um novo padrão para a capacitação e certificação em agrotóxicos. Os novos procedimentos foram desenhados por grupos de trabalhos envolvendo órgãos federais e regionais, e serão implementados ao nível local de forma paulatina.

Países como Dinamarca, Alemanha, Holanda, Noruega, Suécia e Suíça obrigam a capacitação e certificação de todos os usuários de agrotóxicos e, em alguns casos, de todos os fornecedores, vendedores ou armazenadores. Na Suécia, onde esta medida foi estabelecida em 1990, envolvendo todos os agricultores e trabalhadores rurais que fazem aplicação de agrotóxicos, as autoridades pesquisadas apontam esta iniciativa 
como a mais bem sucedida medida de redução de riscos dos agrotóxicos. Todos os profissionais que trabalham na aplicação de produtos (cerca de 30.000 pessoas) completaram programas de capacitação com carga-horária mínima de 24 a 32 horas. A Suíça também identifica o programa de certificação, adotado desde 1971, como responsável pela grande redução nos casos de acidentes e intoxicações.

A França conduz cursos e treinamentos para manipuladores e aplicadores, visando especialmente a difusão e adoção de medidas e procedimentos de segurança.

Muitos países obrigam os usuários dos produtos mais tóxicos a serem capacitados e certificados, ou a trabalharem sobre orientação de alguém que atende a estes requisitos. Alguns países ainda restringem a venda com base no nível de capacitação dos vendedores(na Hungria os produtos de classe I - mais tóxicos - somente podem ser vendidos para especialistas com grau universitário; os classe II já podem ser vendidos para agricultores treinados; e os de classe III - menos tóxicos - são de venda livre).

O licenciamento de revendas e distribuidores também tem constituído parte das estratégias de regulamentação dos países da OECD. Alguns países relatam haver obrigatoriedade de que os comerciantes mantenham em seus quadros um certo número de funcionários treinados e capacitados a fornecer orientações aos vendedores e clientes.

$\mathrm{Na}$ Austrália a indústria desenvolve um programa de autorização de revendas, onde o fornecimento é condicionado a existência de um quadro de pessoal treinado.

No Canadá a indústria conduz uma iniciativa para instituir um padrão nacional de armazenamento, incluindo quesitos como: características de construção, equipe treinada, informação documentada sobre segurança, programas de manutenção, seguro, e planos de emergência. As companhias sustentam uma cláusula de não fornecimento aos revendedores e distribuidores que não estejam de acordo com os padrões adotados. Em 1995 cerca de 1260 pontos de comércio atendiam aos programa estabelecido. $\mathrm{Na}$ França, programas semelhantes aos do Canadá foram recentemente iniciados. 
Suplementando os programas de capacitação de agricultores, muitos países relataram a elaboração e distribuição de material instrucional sobre segurança no uso de agrotóxicos.

Um dos maiores esforços relatados na pesquisa diz respeito a distribuição de cerca de 2 milhões de cartilhas e 500.000 cartazes promovida pelo governo dos EUA, como parte da nova regulamentação federal sobre segurança do trabalhador.

Todos os países da OECD contam com regulamentos de rotulagem para oferecer orientações sobre o uso seguro dos agrotóxicos. Entretanto todos reconhecem as limitações da rotulagem como instrumento de manejo dos riscos, uma vez que constatam a tendência dos usuários em não ler atentamente os rótulos e bulas, e ainda as dificuldades de entendimento dos conteúdos divulgados.

A Suíça emitiu nova regulamentação sobre segurança do trabalho no início dos anos 90. No mesmo período os Estados Unidos também promoveram revisão em seus regulamentos, agregando novos requisitos tais como: período de reentrada em áreas tratadas, suprimento obrigatório de equipamentos de proteção individual, disponibilidade de água e sabão para dos trabalhadores de campo, comunicação de riscos aos trabalhadores, dentre outras medidas.

Durante os últimos 5 anos (91 a 96) vários países da OECD iniciaram programas para enfrentar os problemas decorrentes do descarte de embalagens e de estoques de produtos proibidos. Alguns países buscam soluções preventivas instruindo os agricultores a não manterem estoques de produtos. Estabelecem ainda sistemas de retorno de embalagens vazias aos revendedores e distribuidores, para posterior destinação final.

O incremento da eficiência e efetividade do controle de pragas também é adotado como estratégia de redução dos riscos dentre os diversos países pesquisados. Todos relataram melhorias nos prognósticos de incidência de pragas, e observaram ainda que 
os limiares de tratamento para várias culturas têm sido aprimorados, propiciando a redução de uso por parte dos produtores.

Os países da OECD também descreveram o sucesso de novos programas nas áreas de: testes e certificação de equipamentos de aplicação; desenvolvimento de melhores equipamentos e técnicas de aplicação; e pesquisas sobre o impacto da redução das taxas de aplicação na produção das culturas.

Todos os países da OECD pesquisados têm desenvolvido programas de manejo integrado de pragas, nos últimos 10 anos. Tais programas podem contempla várias estratégias e formatos, incluindo: desenvolvimento e auxílio no uso de agentes biológicos para o controle das pragas; provimento de variedades resistentes e de plantas sadias aos produtores; desenvolvimento de estratégicas não-químicas para o controle de pragas; e fornecimento de material instrucional e de difusão de informações sobre técnicas de MIP aos os agricultores.

Cinco dos países pesquisados relataram o estabelecimento de fazendas modelo e campos de demonstração dos métodos de MIP, visando difundir informações sobre a viabilidade econômica e os benefícios ambientais provenientes desses métodos.

Os países da OECD utilizam de 3 tipos de instrumentos econômicos para encorajar o uso de MIP e de métodos orgânicos:

- subsídios para o uso de práticas agrícolas "ambientalmente amigáveis";

- rotulagem ambiental para agregar vantagens de mercado aos produtores que se utilizam de tais métodos;

- taxas sobre os pesticidas para aumentar seus preços e dessa forma desencorajar o uso desnecessário.

Tanto os países individuais como a Comissão Européia concedem subsídios. Alguns países relatam que estes programas são bem sucedidos. Um pequeno número de países e a CE descrevem uso da rotulagem ambiental e alguns relatam haver 
demanda crescente por produtos com "selo verde". Apenas 3 países relataram o uso de taxas sobre os agrotóxicos para tentar reduzir o uso desnecessário.

Em relação aos programas nacionais com objetivos de redução do uso o relatório da OECD informa que durante o final dos anos 80 e ao início dos 90 vários países da OECD e da CE iniciaram programas gerais de redução de uso de agrotóxicos.

A Suécia, a Dinamarca e a Holanda, foram os primeiros países a adotarem tais programas. Tais países relataram resultados consideráveis na redução do uso, embora não tenham atingido as metas preconizadas em cada caso.

Outro resultado obtido foi a maior atenção por parte dos agricultores em relação aos riscos decorrentes dos pesticidas, e o reforço de seus compromissos com as metas de redução do uso.

A Finlândia, Noruega, e as províncias canadenses de Quebec e Ontário também relataram o início de programas de redução do uso de agrotóxicos.

A segunda parte do relatório produzido pela OECD sobre as atividades dos diversos países na redução dos riscos provenientes do uso de agrotóxicos, foi dedicada aos países integrantes da FAO e não participante da $\mathrm{OECD}$, selecionados para o estudo.

Tais países (Equador, Jamaica, Coréia, Malásia, África do Sul, Sri Lanka, Tailândia e Zâmbia) também relataram que suas experiências diretas com o uso indiscriminado e a necessidade de desenvolvimento de práticas agrícolas sustentáveis constituíram fatores de motivação para a implementação de esforços de redução de riscos.

Estes países guardam vários pontos em comum em relação às estratégias adotadas para a redução de riscos dos agrotóxicos: nenhum país pesquisado desenvolve programas específicos de redução de riscos, mas todos contam com legislações, 
geralmente voltadas aos processos de registro dos produtos, as quais cobrem algumas atividades que implicam na redução dos riscos.

Outras características comuns observadas são: alto grau de cooperação entre ministérios, universidades, hospitais, organizações não-governamentais, agências internacionais e bilaterais, e o setor privado.

Os problemas comuns apontados no relatório dizem respeito a dificuldades no desenvolvimento de programas e materiais de treinamento apropriados para os agricultores de subsistência, os quais freqüentemente são analfabetos, falam vários tipos de dialetos ou línguas, e muitas vezes não têm consciência dos riscos oferecidos pelos agrotóxicos.

Também são relatadas dificuldades relativas a ausência de equipes de extensão rural, inadequação dos recursos e infra-estrutura insuficiente.

A pesquisa mostrou que o registro de pesticidas têm sido implementado na maioria desses países em desenvolvimento, provendo uma boa base para as ações de redução de riscos. Todavia há a necessidade de melhorar a eficiência e a harmonização dos procedimentos e requisitos de registro.

Atividades de treinamento são amplamente utilizadas, embora seja difícil medir o sucessos dessas iniciativas.

Atividades de capacitação e treinamento em segurança não são por si só suficientes, mas devem ser acompanhadas pela disponibilidade de produtos e práticas alternativas, assim como de uma maior preocupação com as questões ambientais.

A promoção de estratégias de uso baseado na necessidade real constatada tem tido algum sucesso, mas apresenta também alguns problemas, na medida em que os agricultores se mostram relutantes na redução do uso de agrotóxicos, pois temem colocar sob risco os investimentos feitos em suas culturas. 
O estudo da OECD relata que países em desenvolvimento ainda encontram sérios problemas e necessidades relacionadas ao uso de agrotóxicos, mas também já desenvolveram uma boa experiência em técnicas de redução de riscos.

Um dos fatores identificados como de grande valia para o incremento das ações de redução de risco seria a implantação de uma rede coordenada de trabalho que permitisse a troca de experiências, informações, e possibilitasse a harmonização da legislação, pelo menos ao nível regional. Tal atividade poderia ser bem desenvolvida a partir do suporte das agências de cooperação internacional e de programas globais tais como o IFCS - "Intergovernamental Fórum on Chemical Safety", promovido pelos organismos ligados às Nações Unidas. 


\section{A RECEITA BRASILEIRA NO CONTROLE DOS RISCOS}

A implantação do sistema de receituário agronômico no Brasil, caracterizada atualmente como exigência legal de autorização escrita para a comercialização e aplicação de agrotóxicos, foi resultado de um longo processo de discussão na comunidade técnica do meio agronômico, iniciada por profissionais atuantes no estado do Rio Grande do Sul, em torno dos problemas identificados pelo uso indiscriminado desses insumos gerando os impactos ao ambiente e à saúde humana.

Um dos atores que tiveram participação ativa nesse debate foi o engenheiro agrônomo Sebastião Pinheiro. Sua atuação profissional no Rio Grande do Sul, inicialmente como vendedor de agrotóxicos (1973) e posteriormente como técnico da cooperativa tritícola de Erexim (RS) nos anos de 1974 a 1976, e em seguida como funcionário do Ministério da Agricultura (a partir de 1976), propiciou o contato direto com os problemas que serviriam de base para a implantação do receituário.

"A comercialização dos venenos agrícolas, no Brasil, após a implantação da Ditadura de 64, foi feita totalmente subsidiada através do crédito rural. Os vendedores iam às propriedades, e o agricultor era "enrolado", comprando o que o vendedor oferecia. Depois, com a assinatura do agricultor, o mascate ia ao Banco do Brasil, de lá o dinheiro era repassado diretamente para a conta da empresa no Rio ou em São Paulo." (PINHEIRO, 1993:88). 
As discussões sobre os problemas decorrentes do uso indiscriminado de agrotóxicos ocupavam as manchetes de revistas voltadas ao setor agropecuário, demonstrando o grau de preocupação que já começava a tomar conta da comunidade técnica e da opinião pública ligada ao tema.

Em reportagem da revista "Dirigente Rural", publicada em outubro de 1974, observa-se o surgimento do debate em torno da tecnologia química e suas decorrências na atividade agropecuária.

"...Dia a dia surgem argumentos a favor ou contra o uso de defensivos. Compelidos pelo clamor contra os produtos químicos, cientistas têm procurado encontrar novas armas eficientes e economicamente viáveis para enfrentar as pragas e doenças..." (Dirigente Rural, outubro/novembro, 1974:22).

A experiência de outros países que mantinham políticas mais restritas no uso dessa tecnologia também já era conhecida pelos envolvidos nas discussões sobre os agrotóxicos, e servia de base para a proposição de mecanismos legais mais restritivos para estes produtos no Brasil.

"...A par de tais tentativas na área científica, providências de ordem legal são cada vez mais adotadas, com vistas a eliminar, por meio de regulamentos severos, possíveis riscos ligados a uso de defensivos ou a reduzi-los a uma escala inofensiva para o homem. Nesse sentido, países como os Estados Unidos, Suécia e República Federal da Alemanha já proibiram ou limitaram de forma bem rígida a utilização de diversos produtos, além de decretarem instruções de emprego rigorosas..."(Dirigente Rural, outubro/novembro, 1974:25).

A ação de pequenos grupos de técnicos de diversas jurisdições do interior do estado do Rio Grande do Sul, na adoção da prescrição técnica para caracterizar a necessidade impreterível de uso do produto, é relatada como fruto da reação aos impactos já naquela altura identificados como decorrentes do uso abusivo dos agrotóxicos. 
“...Foi proposto um fim a estes abusos, idealizando-se a prescrição técnica, a priori, para caracterizar a necessidade impreterível do produto químico. E nasceu o instrumento de controle batizado de Receituário Agronômico” (PINHEIRO, 1993:88).

O Serviço de Extensão Rural no Rio Grande do Sul implantou definitivamente o receituário agronômico a partir do ano de 1978. Até então o "Bloco de Recomendações Técnicas" (Figura 11) era o único instrumento utilizado de forma ampla para a prescrição de toda e qualquer recomendação técnica, no trato dos mais variados problemas em relação a sementes, adubos, corretivos, rações, máquinas e materiais para construção rural, nas propriedades rurais assistidas (SECCHI,1986:1).

Figura 11 - Modelo de "Bloco de Recomendações Técnicas" utilizado pelo Serviço de Extensão Rural no Rio Grande do Sul, anterior à implantação do receituário (1978).

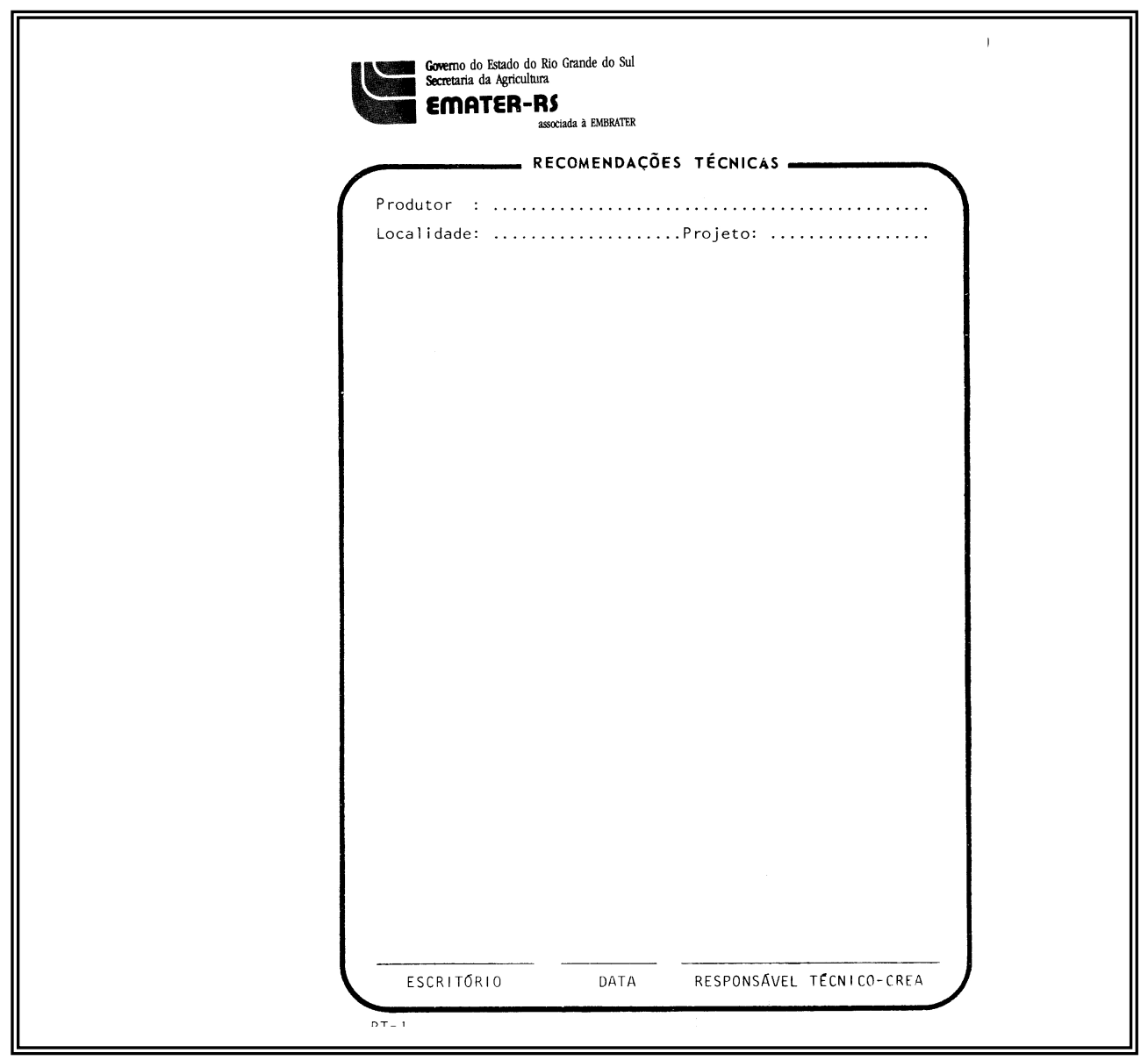

Fonte: EMATER - RS 
Conforme observa SECCHI (1986), impulsionado pelo movimento da classe agronômica que lutava na região da Grande Santa Rosa, em favor da restrição do uso dos agrotóxicos organoclorados e dos altamente tóxicos, o CREA-RS aprova o ATO $\mathrm{N}^{\mathrm{o}} 2 / 73$, estipulando que em toda venda de produtos cuja $\mathrm{DL}_{50}$ oral aguda fosse igual ou inferior a $50 \mathrm{mg} / \mathrm{kg}$ ou $\mathrm{DL}_{50}$ dermal igual ou inferior a $200 \mathrm{mg} / \mathrm{kg}$, ou ainda, em toda aplicação em Ultra Baixo Volume (UBV), haveria a necessidade de emissão de uma Anotação de Responsabilidade Técnica (ART).

Desta forma, esse instrumento legal pode ser identificado como o "embrião" precursor do receituário agronômico no Estado do Rio Grande do Sul.

No ano de 1974, a ocorrência crescente dos casos de acidentes com agricultores e as agressões ambientais envolvendo o uso de agrotóxicos, especialmente no Rio Grande do Sul, serviram de inspiração para uma importante recomendação resultante da "I Convenção Regional do Centro de Estudos de Toxicologia do Rio Grande do Sul", realizada em agosto daquele ano. A proposta dos convencionais preconizava um sistema de bloqueio regional para os agrotóxicos altamente tóxicos ou persistentes, e a comercialização destes produtos deveria passar a exigir a prescrição de um engenheiro agrônomo responsável.

A idéia foi ratificada um ano mais tarde, durante o "Simpósio sobre Toxicologia dos Pesticidas e Envenenamento Ambiental", organizado pela Sociedade de Agronomia do Rio Grande do Sul, em abril de 1975, na cidade de Porto Alegre. (GUERRA, 1982).

Como primeira experiência prática registrada, surgiu o sistema implantado pelo núcleo de agrônomos de Santa Rosa (RS), no ano de 1975, a partir da formação de uma rede de controle da comercialização, contando com a sensibilidade e participação do agente financeiro local (Banco do Brasil). 
"...os agrônomos se agrupavam em núcleos e procuravam implanta-lo na sua jurisdição, como forma de bandeira política...

...o núcleo de agrônomos de Santa Rosa, RS, tinha um bom controle da comercialização dos venenos, pois - coisa rara - o gerente do Banco do Brasil compreendera a importância social de se ter um controle sobre aqueles produtos, ardilosamente chamados de defensivos agrícolas...

....o exemplo de Santa Rosa alastrou-se rapidamente para outros municipios....o talonário de receitas era distribuído pela Sociedade de Agronomia do Rio Grande do Sul, que aglutinava e agrupava estatutariamente todos os núcleos..." (PINHEIRO, 1993:88-89).

Uma primeira avaliação das experiências com a implantação da receita é realizada durante o "III Encontro de Engenheiros Agrônomos do Rio Grande do Sul", realizado em Porto Alegre, no período de 27 a 30 de junho de 1976. Naquela ocasião foi apresentado um relato sobre a experiência posta em prática com sucesso pela Associação dos Engenheiros Agrônomos do Nordeste do Rio Grande do Sul (AENORGS), seguindo a recomendação da convenção Centro de Estudos de Toxicologia, de 1974. O relato fazia menção aos resultados positivos auferidos na redução do uso de agrotóxicos no município de Santa Rosa (RS), a partir da venda controlada através de receita nas cooperativas da região. A comissão que analisou o trabalho deu parecer nos seguintes termos:

"O trabalho foi considerado de grande significação por apresentar um procedimento prático e eficiente para promover a proteção do homem, as fontes de água tanto rurais como urbanas, a preservação da fauna e controle eficaz aos fitoparasitas, ao mesmo tempo em que promove a atuação do Engenheiro Agrônomo. A adoção generalizada do uso do receituário de defensivos agrícolas constitui-se em meta prioritária da FAEAB." (GUERRA, 1982). 
A repercussão da experiência de Santa Rosa (RS) movimenta a ação do Conselho de Desenvolvimento Agropecuário do Rio Grande do Sul, que através da Resolução nº11, de 14 de novembro de 1977, recomenda, de forma unânime, duas medidas de impacto na questão do uso indiscriminado de agrotóxicos: a redução máxima do uso dos produtos organoclorados; e a implantação do receituário agronômico em todo o estado.

"Foi nesta mesma oportunidade que a EMATER, como entidade integrante do Conselho, determinou que o Receituário Agronômico seria emitido gratuitamente às propriedades rurais assistidas, sempre que houvesse absoluta necessidade de aplicação de defensivos agrícolas" (SECCHI, 1986:2).

Atendendo a esta mesma recomendação do Conselho Agropecuário do Estado do Rio Grande do Sul, o Banco do Brasil, através da "Carta Grupal n²697", de fevereiro de 1978 (Figura 12), determina que as verbas destinadas aos tratamentos fitossanitários somente poderiam ser liberadas mediante a apresentação da receita agronômica. Assim, conforme assinala Guerra, "estava, desta maneira, implantado, de fato, o receituário agronômico no Estado do Rio Grande do Sul, e, portanto, no Brasil" (GUERRA, 1982:20). 
Figura 12 - Carta-circular do Banco do Brasil, destinada às agências do Estado do Rio Grande do Sul, instituindo o receituário agronômico nas operações de crédito efetuadas pelo banco. Brasília, fevereiro de 1978

BANCO DO BRASIL S.A. Brasília, 07.02.78

CARTA-CIRCULAR GRUPAL No 2.697

Agências destinatárias do Estado do

RIO GRANDE DO SUL.

CIC RURAL 6-1 - CONDIÇÕES GERAIS - Disposições preliminares - Defensivos para a agropecuária - Os malefícios trazidos ao meio ambiente pelo uso desordenado de defensivos agrícolas altamente tóxicos vêm causando sérias preocupações às autoridades responsáveis, bem como às entidades que congregam técnicos da área rural.

2. Dentre outras providências articuladas para enfrentar o problema, destaca-se a implantação do receituário agronômico para os defensivos agrícolas, medida que visa a evitar, principalmente, o uso inadequado de produtos mais tóxicos.

3. O Banco foi solicitado a colaborar na difusão dessa prática, mediante a exigência do receituário, na concessão dos financiamentos da espécie.

4. Cabe registrar que, consoante informações divulgadas pelo Banco Central do Brasil, em sua CartaCircular $\mathrm{n}^{\circ} 229$, de 19.05.77, "cumpre ao assessoramento técnico promover as espécies e quantidades de defensivos agrícolas ..... às lavouras assistidas, de conformidade com as características da região".

Assim, com o intuito de engajar o banco na ......... as agências obter o receituário agronômico em causa. Este documento será dispensável quando constatados óbices capazes de impedir a rápida e oportuna liberação dos créditos. A obrigatoriedade recairá, contudo, sobre as operações correspondentes a empreendimentos assistidos tecnicamente.

Fonte: transcrito de PINHEIRO et al., 1993

A mobilização crescente da opinião pública em torno das discussões sobre a questão do uso indiscriminado de agrotóxicos em todo o país começava a desencadear movimentações nas esferas governamentais, na busca de criação de espaços institucionais para o debate e as deliberações sobre o tema.

É neste contexto que em agosto de 1977, logo após a recomendação emanada pelo Conselho de Desenvolvimento Agropecuário do Rio Grande do Sul, a favor da adoção do receituário, o Ministério da Agricultura aprova a Portaria $\mathrm{n}^{\circ} 610$, constituindo a Comissão de Defensivos Agrícolas, como órgão consultivo da Divisão de Defesa Sanitária Vegetal, contando com representantes do próprio Ministério de Agricultura; do Ministério da Saúde; da Secretaria Especial do Meio Ambiente (Ministério do Interior); do Instituto Biológico da Secretaria de Agricultura e Abastecimento do 
Estado de São Paulo; do Instituto Adolfo Lutz da Secretaria de Saúde do Estado de São Paulo; e da Associação Nacional de Defensivos Agrícolas - ANDEF.

As motivações apresentadas na justificativa da criação da comissão apontavam para a "necessidade de serem conciliados os aspectos fitossanitários, de saúde pública e de defesa do meio ambiente, no uso de defensivos agrícolas; ...necessidade da existência de uma Comissão interministerial que estude os problemas relacionados com o registro e licenciamento dos defensivos agrícolas" (GALVÃO, 1977/78:111).

As reações de oposição às iniciativas de controle do uso indiscriminado dos agrotóxicos no Rio Grande do Sul são imediatamente desencadeadas como produto da ação desta Comissão, no sentido de restringir as experiências levadas a efeito por aquele estado, na implantação do receituário agronômico. O texto da Recomendação nº1, de 17 de outubro de 1978, deixa claro os pontos de controvérsia existentes sobre a implantação e operacionalização do receituário agronômico (Figura 13). 
Figura 13 - Recomendação n 01 da Comissão de Defensivos Agrícolas, aprovada em 17 de outubro de 1978

\section{COMISSĀO DE DEFENSIVOS AGRICOLAS}

\section{RECOMENDAÇÃO Nọ 01, DE 17 DE OUTUBRO DE 1978}

A COMISSÃO DE DEFENSIVOS AGRICOLAS, no uso de suas atribuições, contidas no item III do Art. 7?, da Portaria Ministerial no 545, de 28 de junho de 1978, publicada no DOU de 5 de julho de 1978 e, CONSIDERANDO:

1. Que a simples receita agronômica, não vai livrar o consumidor e o próprio agricultor, dos riscos de um uso não adequado do produtor:

2. Que a fiscalização do comércio, quanto à venda do produto com receituário, será praticamente impossivel;

3. Que os mecanismos de controle, onerarão o preço do produto;

4. Que a própria receita, será mais um ônus para o agricultor;

5. Que a falta de técnicos especializados em fitossanitarismo, em condições de prescrever um receituário no tempo devido, com bom senso, equilíbrio e responsabilidade e no interesse do produtor, é um fator limitante a adoção do processo,

RESOLVE:

RECOMENDAR, que por adoção e/ou institucionalização do Receituário Agronômico, sejam observadas as seguintes medidas:

I - Não ser restritivo de Crédito Agrícola;

11 - Que todo profissional de agronomia, devidamente registrado no CREA, possa expedir receita;

III - Que haja a responsabilidade técnica quanto ao:

a) diagnóstico;

b) visita;

c) acompanhamento:

d) verificação das cond ições operacionais do agricultor;

e) intervalo de segurança (observação das especificações de uso);

f) preservação do meio ambiente.

IV - Que a exigência do Receituário, prenda-se unicamente, aos defensivos, incluídos nas classes toxicológicas I e II definidos na Portaria Ministerial n: 749/77 (anexo 16);

$V$ - Que a regulamentação e implantação do Recetuário, sob o ponto de vista ético, seja conduzido pelo Conselho Federal de Engenharia, Arquitetura e Agronomia - CONFEA;

VI - Só poderão ser prescritos produtos, em observância às recomendações de uso aprovadas pelo Ministério da Agricultura;

VII - Que o Receituário não seja condicionante da comercialização, a nível regional, dos defensivos agrícolas, sem determinação prévia do Ministério da Agricultura.

Fonte: GALVÃO, D.M. , 1978

As considerações apontadas na citada recomendação demonstravam o sentimento de parte dos integrantes do debate sobre a adoção do receituário. Já os defensores do receituário exploraram com detalhes as contradições explicitadas na recomendação, conforme se observa no artigo de José Lutzemberger, denominado "A máfía dos pesticidas", publicado originalmente no Jornal do Engenheiro Agrônomo da AEASP, em novembro de 1980 (LUTZEMBERGER, 1982).

Um quadro resumo dos argumentos travados neste debate é apresentado a seguir: 
Figura 14 - Quadro resumo dos argumentos apresentados por Lutzemberger, no debate em torno da resolução n01 da Comissão de Defensivos Agrícolas.

\begin{tabular}{|c|c|}
\hline Recomendação n01 da CDA* & Argumentação de Lutzemberger** \\
\hline $\begin{array}{l}\text { "Considerando que, a simples receita } \\
\text { agronômica, não vai livrar o consumidor e o } \\
\text { próprio agricultor, dos riscos de um uso não } \\
\text { adequado do produtor". }\end{array}$ & $\begin{array}{l}\text { "...acaso isso é argumento para não usar uma medida de } \\
\text { segurança adicional" }\end{array}$ \\
\hline $\begin{array}{l}\text { "Considerando que a fiscalização do } \\
\text { comércio, quanto à venda do produto com } \\
\text { receituário, será praticamente impossivel". }\end{array}$ & $\begin{array}{l}\text { "...aqui eles estão reconhecendo a sua própria } \\
\text { irresponsabilidade. Como é que se atrevem a comercializar } \\
\text { produtos como o Temik***, se eles mesmos reconhecem } \\
\text { que não há possibilidade de fiscalização?" }\end{array}$ \\
\hline $\begin{array}{l}\text { "Considerando que os mecanismos de } \\
\text { controle onerarão o preço do produto". }\end{array}$ & $\begin{array}{l}\text { "...mais uma vez aquela preocupação. A saúde nunca vale } \\
\text { nada. O negócio é sempre o que importa." }\end{array}$ \\
\hline $\begin{array}{l}\text { "Considerando que a própria receita será } \\
\text { mais um ônus para o agricultor". }\end{array}$ & $\begin{array}{l}\text { "...isso aqui é uma mentira muito grande. O agricultor que } \\
\text { usa o Receituário aplica menos pesticida. Economiza rios de } \\
\text { dinheiro. Na maioria dos casos, o receituário é gratuito e } \\
\text { quando o agrônomo cobra....Então, o Ministério está } \\
\text { dizendo que a própria receita será mais um ônus para o } \\
\text { agricultor, quando a receita pretende que ele economize, } \\
\text { naturalmente ela é um ônus para as multinacionais." }\end{array}$ \\
\hline $\begin{array}{l}\text { "Considerando que a falta de técnicos } \\
\text { especializados em fitossanitarismo, em } \\
\text { condições de prescrever um receituário no } \\
\text { tempo devido,...é um fator limitante à adoção } \\
\text { do processo". }\end{array}$ & $\begin{array}{l}\text { "...quer dizer que se não houver técnicos capazes de } \\
\text { fiscalizar, então vamos deixar vender livremente..." }\end{array}$ \\
\hline $\begin{array}{l}\text { "Recomenda...as seguintes medidas: ...Não } \\
\text { ser restritivo de Crédito Agrícola". }\end{array}$ & "...pois é justamente aí que nós conseguimos a eficiência". \\
\hline $\begin{array}{l}\text { "Recomenda...as seguintes medidas: ...Que } \\
\text { todo profissional de agronomia, devidamente } \\
\text { registrado no CREA, possa expedir receita". }\end{array}$ & $\begin{array}{l}\text { "...Nós tínhamos conseguido a exclusão dos profissionais } \\
\text { comprometidos com a indústria química. É claro que o } \\
\text { profissional que trabalha para a indústria química está } \\
\text { interessado no assunto. Eu não estou chamando ele de } \\
\text { corrupto, não. Não precisa ser isto. Na medicina, o } \\
\text { farmacêutico está proibido de dar receita, e o médico está } \\
\text { proibido de ser dono de farmácia. Isto é apenas lógico! Nos } \\
\text { pesticidas nós temos exatamente esta situação". }\end{array}$ \\
\hline
\end{tabular}

* Recomendação n01 da Comissão de Defensivos Agrícolas, (GALVÃO, 1978) ** LUTZEMBERGER, 1982 *** Temik: inseticida, acaricida e nematicida sistêmico, à base de Aldicarb, ingrediente ativo pertencente ao grupo químico dos Carbamatos, classe toxicológica I - "extremamente tóxico" 
Mesmo com o surgimento de focos de oposição, ainda incipientes, a experiência de implantação do controle dos agrotóxicos via receita continua a expandir-se.

O Banco do Brasil apresenta um estudo, em abril de 1980, demonstrando a diminuição no uso dos produtos organoclorados e organofosforados mais tóxicos, como decorrência da prática do receituário.

Em carta resposta dirigida ao presidente da Sociedade de Agronomia do Rio Grande do Sul, técnicos do Banco do Brasil posicionam um resumo dos resultados auferidos com a experiência de adoção do receituário nas operações de crédito rural, levada a efeito em 82 agências daquele estado (Figura 15).

Em vista do sucesso obtido no Rio Grande do Sul, a direção do banco resolve expandir para todo o país, a obrigatoriedade do receituário agronômico em todos os financiamentos do crédito rural. Esta medida causou impacto significativo nas perspectivas do mercado de agrotóxicos no Brasil.

"... quando todo o Estado estava coberto, o Banco do Brasil apresentou estudo, demonstrando a diminuição do uso de produtos organoclorados e de produtos fosforados mais tóxicos. Tendo em vista o sucesso, o banco, usando do bom senso, resolvera adotar a obrigatoriedade do Receituário Agronômico para todos os financiamentos de aquisição de venenos. Isto representava mais de 85 por cento das vendas no país" (PINHEIRO, 1993:89). 
Figura 15 - Carta do Banco do Brasil, dirigida ao presidente da Sociedade de Agronomia do Rio Grande do Sul, dando conta dos resultados preliminares decorrentes da adoção do receituário agronômico . (1980)

BANCO DO BFASIL S.A. DIREÇÃ GERAL

Senhor Presidente,

Referimo-nos ao seu expediente SARGS-80/43, de 13.03:80, endereçaci ao Sr. Diretor de Crēdito Rural, deste Banco.

2. Quanto ao trabalho que estamos elaborando, com vistas a avaliar as resultantes da instituição do receituärio agronömico nos financiamentos para a quisição de defensivos agrïcolas, informamos-lhe que, por enquanto, as observa. ções realizadas não nos oferecem o imprescindivel suporte para emitir ilações . concretas e abrangentes sobre o assunto.

3. Salientamos, tambēm, que o interstĩcio da pesquisa sob menção res .. tringe-se, no momento, aos anos de 1977 e 1978, abrigando curtos perĩodos ante riores e posteriores à adoção da medida, motivo que ratifica nossa asserção inicial.

4. Nada obstante, podemos mencionar algumas inferēncias preliminares ' que nos permitem os estudos atë então disenvolvidos, esclarecendo, de antemão, que os subsîdios nos foram remetidos por 82 agências do Banco nesse Estado:

a) redução do uso de defensivos clorados e fosforados;

b) intensificação do emprego de defensivos clorofosforados e carbamatos;

c) a maioria dos receituärios ē fornecida gratuitamente;

d) algumas empresas e profissionais autōnomos cobram, pela receita. $1 \%$ sobre o valor da compra, atë o limite de um salario minimo;

e) com relação ãs entidades cujos tếcnicos mais prescrevem receitas, predominam as cooperativas rurais;

f) o trigo foi a cultura cuja ārea financiada recebeu, percentual mente, maior abrangência do receituärio agronômico.

5. Ao cumprimentar-1he pelo interesse demonstrado no equacionamento de tão relevante assunto, aproveitamos a oportunidade para apresentar-lhe nossos , protestos de elevada consideração.

Ao Ilmo. Sr.

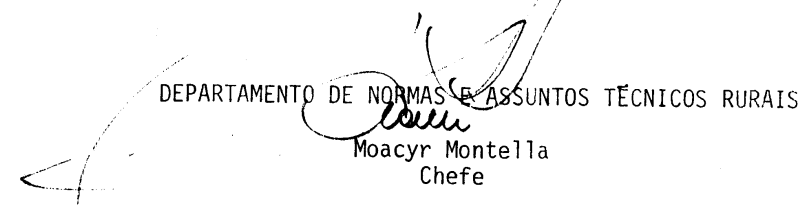

Dr. João Giugliani Filho

DD. Presidente da Sociedade de Agronomia do Rio Grande do Sul

Porto Alegre - RIO GRANDE DO S IIL

Fonte: PINHEIRO, 1993 
A prática do receituário agronômico, desde seu início em 1975 até o ano de 1978, caracterizou-se principalmente como sistema de controle das vendas através de receitas, na medida em que a prescrição por profissional responsável técnico passa a ser exigida como um dos requisitos para aprovação dos projetos de crédito rural que previam o uso dessa tecnologia.

Entretanto, a partir de abril de 1978, surgem os primeiros passos na construção de uma doutrina técnica para o manejo de problemas fitossanitários.

A EMATER implanta um modelo de receituário agronômico (Figura 16) a ser utilizado por suas equipes técnicas, e procura parcerias com a universidade, na busca de reciclagem técnica para seus extensionistas (SECCHI, 1986).

Figura 16 - Modelo de receituário agronômico adotado pela EMATER-RS, em 1978 (frente e verso)

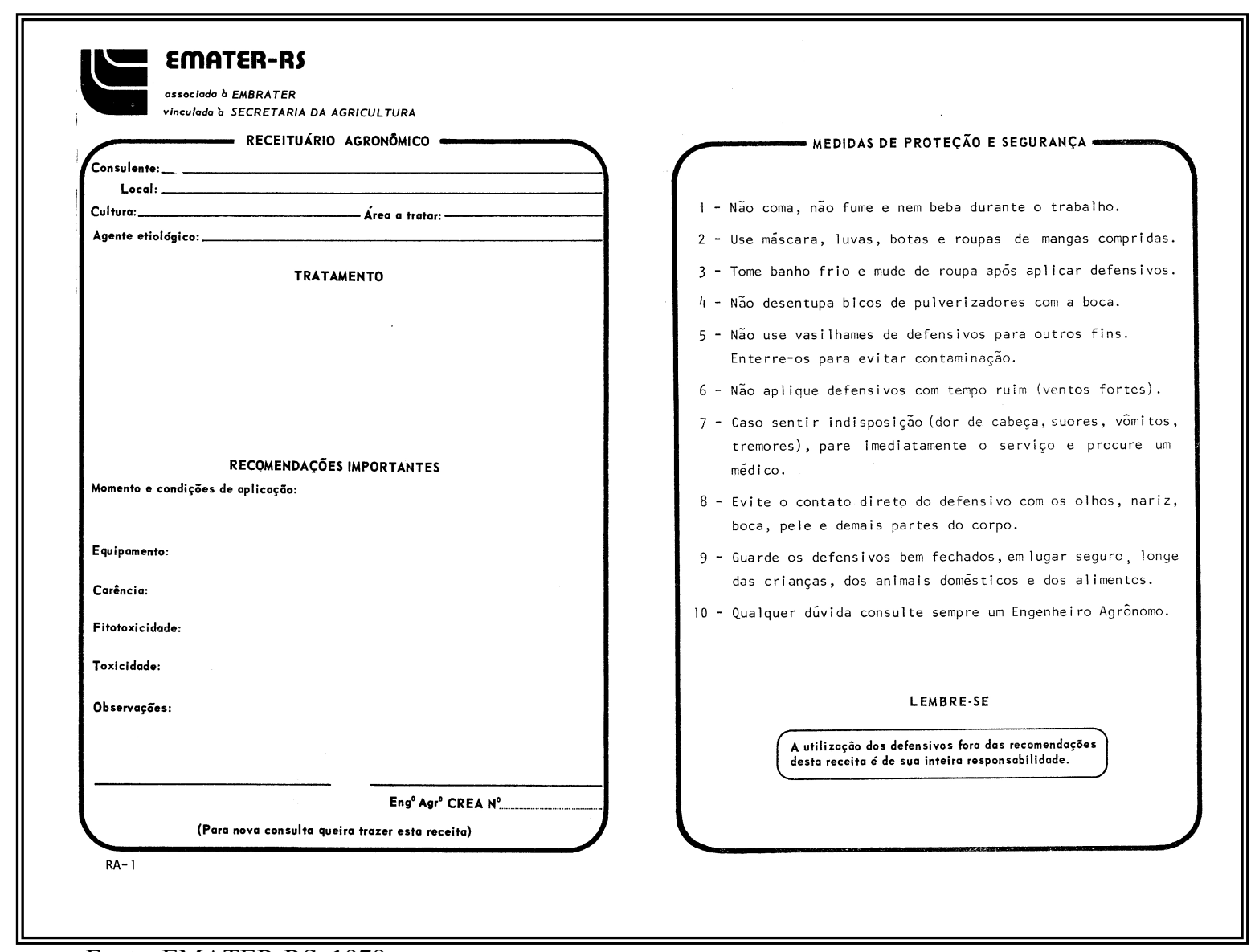

Fonte: EMATER-RS, 1978 
Com a realização do "1 Curso Sobre Fundamentos do Receituário Agronômico", promovido pela Sociedade de Agronomia do Rio Grande do Sul (SARGS), em conjunto com o Centro de Estudos de Toxicologia do Rio Grande do Sul, contando também com o apoio fundamental da Universidade Federal de Pelotas, a expressão "receituário agronômico" começa a tomar novo conteúdo, sugerindo uma nova metodologia de abordagem técnica dos problemas de proteção de plantas, na produção agrícola e florestal.

O professor Milton de Souza Guerra, titular do Departamento de Fitossanidade da Faculdade de Agronomia Eliseu Maciel (FAEM), da Universidade Federal de Pelotas/RS (UFPel), surgiu como um dos principais idealizadores da metodologia do receituário agronômico. Ele participou ativamente do curso organizado em Pelotas/RS e narra agora, em publicação recente sobre o tema, sua visão sobre a construção do receituário:

"...Sentindo a necessidade de estabelecer uma unidade de doutrina profissional em face a este novo procedimento agronômico .....promoveram...o "1 $1^{o}$ Curso Sobre Fundamentos do Receituário Agronômico". Ficava assim concretizada uma filosofia e estabelecida uma metodologia para o Receituário Agronômico" (GUERRA \& SAMPAIO, 1991:21).

Uma rápida observação no conteúdo programático desenvolvido durante o curso realizado na Universidade de Pelotas/RS sugere a dimensão atribuída à época ao receituário agronômico, não como simples sistema de controle de vendas, mas como atividade técnica da prática agronômica, conforme se verifica na Figura 17, a seguir. 
Figura 17 - Tópicos do conteúdo programático desenvolvido no "1 1 Curso sobre Fundamentos do Receituário Agronômico", e respectivos docentes. Pelotas, RS, abril de 1978.

\begin{tabular}{|c|c|}
\hline Tópico & Autor \\
\hline Ética profissional & $\begin{array}{l}\text { Prof. José Álvares de Souza Soares } \\
\text { Sobrinho }\end{array}$ \\
\hline $\begin{array}{l}\text { Receituário Agronômico - Conceito, Objetivos e } \\
\text { Elaboração }\end{array}$ & Prof. Daiser Paulo Sampaio \\
\hline Fenologia dos Fatores Etiológicos & $\begin{array}{l}\text { Prof. Daiser Paulo Sampaio Prof. } \\
\text { Milton de Souza Guerra }\end{array}$ \\
\hline Análise Conceitual do Receituário Agronômico - Glossário & Prof. Milton de Souza Guerra \\
\hline Fatores Determinantes da Eficiência da Prescrição Técnica & $\begin{array}{l}\text { Prof. Milton de Souza Guerra } \\
\text { Prof. Daiser Paulo Sampaio } \\
\end{array}$ \\
\hline Fatores Limitantes da Prescrição Técnica & $\begin{array}{l}\text { Prof. Daiser Paulo Sampaio } \\
\text { Prof. Milton de Souza Guerra }\end{array}$ \\
\hline Semiotécnica do Receituário Agronômico & Prof. Daiser Paulo Sampaio \\
\hline $\begin{array}{l}\text { Conceito Ético Psicológico no Relacionamento entre } \\
\text { Técnicos e Consulentes }\end{array}$ & Prof. Daiser Paulo Sampaio \\
\hline Análise de Laboratório e Interpretação de Resultados & Prof. Gastão Gisler \\
\hline $\begin{array}{l}\text { Posicionamento do Receituário no Contexto do Controle } \\
\text { Integral }\end{array}$ & Prof. Milton de Souza Guerra \\
\hline $\begin{array}{l}\text { O Receituário Agronômico como Medida Preventiva de } \\
\text { Acidentes e Intoxicações pela Exposição e ou Manipulação } \\
\text { de Defensivos Agrícolas }\end{array}$ & Prof. Milton de Souza Guerra \\
\hline Aspectos Econômicos do Controle Químico & $\begin{array}{l}\text { Prof. Geraldo Tholozan Dias da } \\
\text { Costa }\end{array}$ \\
\hline Noções Preliminares sobre Inseticidas & Prof. Enrique Salazar Cavero \\
\hline Fungicidas & Prof. Gilberto Ceciliano Luzzardi \\
\hline Responsabilidade Técnica do Engenheiro Agrônomo & Prof. Orlando Magalhães Filho \\
\hline $\begin{array}{l}\text { Primeira Listagem Analítico-Indicativa dos Defensivos } \\
\text { Agrícolas }\end{array}$ & $\begin{array}{l}\text { Prof. Milton de Souza Guerra } \\
\text { Prof. Daiser Paulo Sampaio } \\
\end{array}$ \\
\hline $\begin{array}{l}\text { Dados e Informações Subsidiárias para o Receituário } \\
\text { Agronômico }\end{array}$ & $\begin{array}{l}\text { Prof. Milton de Souza Guerra } \\
\text { Prof. Daiser Paulo Sampaio }\end{array}$ \\
\hline
\end{tabular}

Fonte: UFPel. Centro de Treinamento do Sul (CETREISUL), 1978 
$\mathrm{Na}$ apresentação do curso que tinha como objetivo "reciclar a classe agronômica rio-grandense", o receituário agronômico era definido como "um valioso instrumento que disciplinará a comercialização e o uso dos diferentes defensivos agrícolas, através da interveniência do profissional em Agronomia" (UFPel, 1978:7).

A expectativa criada na "invenção" do sistema de receitas colocava grande ênfase no aporte técnico como base para sucesso da iniciativa: "...esses conhecimentos, aliados aos estudos da eficiência de novos defensivos menos tóxicos e, portanto, de menor risco, permitirão o estabelecimento de um sistema eficiente de controle" (UFPel, 1978:7).

A crença em que o instrumento viria a contribuir para a melhoria dos problemas ambientais decorrentes do uso indiscriminado também estava presente na concepção dos promotores do curso:

"Este sistema instituído se caracterizará por considerar o problema do equilíbrio ecológico e por reduzir, ao mínimo, as probabilidades de inconvenientes do uso generalizado dos defensivos, entre os quais se salienta a poluição ambiental" (UFPel, 1978:7).

A grande diversidade de produtos comerciais disponíveis no mercado sinalizava a complexidade na tomada de decisão do usuário final, e a participação de um profissional habilitado nesse processo era apontada como fundamental.

"No Brasil, aproximadamente mais de 500 princípios ativos de pesticidas são utilizados para a elaboração de cerca de 3.000 formulações que se encontram no comércio. À vista deste fato, conclui-se a impossibilidade de o agricultor eleger e manipular estes produtos, devendo, portanto, valer-se do Engenheiro Agrônomo para sua correta orientação.

...Preconiza-se a interveniencia de profissional habilitado para que os produtos altamente tóxicos ou de larga persistência nos alimentos, no solo ou nas águas, 
mediante a seletividade do mencionado receituário, tenham sua comercialização regrada através da prescrição agronômica" (UFPel, 1978:7-8).

Nesta linha de argumentação o paralelo com a área médica começa a ser traçado e vai permear muitas outras argumentações desenvolvidas ao longo do debate entre os defensores da idéia do receituário e seus opositores.

"Na área médica, existe listagem de produtos que somente podem ser comercializados mediante receita médica, visando à proteção individual no campo da saúde humana. Os pesticidas, entretanto, são vendidos livremente e, não só causam danos à saúde individual, como também provocam casos de intoxicações coletivas, mortes, poluição ambiental e extermínio da fauna e flora" (UFPel, 1978:7).

Outro componente presente na institucionalização do receituário agronômico, desde os primeiros momentos de concepção da idéia, foi a visão de difusão do instrumento como bandeira de luta da classe agronômica. Um dos atores principais nessa linha foi a Sociedade de Agronomia do Rio Grande do Sul. Sua diretoria, ao fazer a apresentação do " $1^{\circ}$ Curso sobre Fundamentos do Receituário" explicitava o papel do receituário junto à corporação agronômica.

\section{"COLEGAS!}

A Sociedade de Agronomia do Rio Grande do Sul espera encontrar, em cada colega, um verdadeiro paradigma em prol da consolidação desta campanha que, sem dúvida, abre nova era na gloriosa história das lutas classistas, no sentido de engrandecer e valorizar, profissionalmente, o Engenheiro Agrônomo" (UFPel, 1978:8)

Depois deste primeiro curso levado a efeito em Pelotas/RS, vários outros foram ministrados, cobrindo todo o Estado do Rio Grande do Sul, de Santa Catarina, Paraná, em Belém, Vitória, Salvador, Goiânia, Brasília, Dourados, Porto Velho, além de várias palestras em diferentes pontos do país. 


\section{1. A construção dos conceitos em torno do receituário}

As experiências levadas a efeito pelos grupos profissionais do Rio Grande do Sul foram constituindo uma visão comum sobre os conceitos que sustentariam a prática do receituário agronômico.

O engenheiro agrônomo Milton de Souza Guerra, que atuava como professor titular de Entomologia no Departamento de Fitossanidade da Universidade Federal de Pelotas, na época de discussão e implantação do receituário, e o Médico Veterinário Daiser Paulo de Almeida Sampaio, professor titular livre-docente do Departamento de Clínicas Veterinárias da mesma universidade, contribuíram fortemente para a construção de um modelo de concepção prática do receituário, buscando diferenciá-lo de uma atividade burocrática limitada a servir como instrumento de controle das vendas de agrotóxicos.

"A receita agronômica é o documento pelo qual o profissional se identifica, se situa, se apresenta e preconiza o recurso terapêutico, preventivo ou curativo, em função do diagnóstico. É o instrumento utilizado pelo engenheiro agrônomo para determinar, esclarecer e orientar o agricultor sobre como proceder ao usar um agrotóxico ou outra medida alternativa da defesa sanitária vegetal. Constitui a etapa final de toda uma metodologia semiotécnica, da qual o profissional se valeu para tirar usas conclusões relativas ao problema" (GUERRA \& SAMPAIO, 1991: 30-31).

Conforme estes autores, dentre os princípios gerais que subsidiariam a filosofia do receituário agronômico estariam dois pontos fundamentais: o receituário deveria preconizar medidas de controle populacional de espécies potencialmente pragas, objetivando evitar que atinjam o nível de dano econômico; e ainda estabelecer os critérios metodológicos, para simultaneamente, preservar a saúde humana, animal e ambiental, sem prejuízo da produtividade. 
“...Portanto, a precisão diagnóstica que vai, em grande parte, garantir o êxito do tratamento, apoia-se no conhecimento exato e pleno do agente etiológico. E, os procedimentos terapêuticos preconizados deverão considerar os aspectos toxicológicos e os conceitos ecológicos relacionados" (GUERRA, 1982).

A aplicação dessa filosofia na prática do receituário estaria sugerindo uma atitude bem definida para o papel do técnico extensionista na busca de soluções aos desafios impostos pelos problemas do manejo fitossanitário.

“Depreende-se destes dois princípios, ser indispensável a presença do agrônomo junto à lavoura, seu paciente, seguindo uma metodologia racional de exames da situação para poder realmente qualificar e quantificar a gravidade e a abrangência do processo, para estabelecer um conceito final e prescrever um procedimento a ser atendido. Isso equivale a dizer que nenhuma receita é tecnicamente válida e honesta se o técnico não estudou o problema com base na semiotécnica agronômica e preceitos etio-ecotoxicológicos “in loco” (GUERRA, 1982).

Um conceito básico na doutrina do receituário agronômico preconizada por Guerra \& Sampaio é a chamada semiotécnica agronômica. Este termo foi definido pelos autores como "um conjunto de procedimentos que, através de informes, sinais, etc. conduzem o profissional ao conhecimento do problema e a sua origem (diagnóstico etiológico)" (SAMPAIO, 1978:23).

É na definição da chamada semiotécnica agronômica que os precurssores da doutrina do receituário agronômico passaram a se apropriar da linguagem característica utilizada na relação "médico-paciente", transposta para a situação de "técnico-consulente", alimentando um suposto paralelo sugerido entre a prática médica e a atividade agronômica

Uma rápida análise do glossário apresentado pelos autores do curso sobre o receituário oferece uma visão geral da linguagem e dos conceitos concebidos para utilização no exercício do receituário agronômico (Figura 18). 
Figura 18 - Alguns componentes do "Glossário de termos e conceitos em Receituário Agronômico", apresentado no "1 Curso sobre Fundamentos do Receituário Agronômico". Pelotas/RS - 1978

\begin{tabular}{|c|c|}
\hline Termos & Conceitos \\
\hline Agente etiológico & $\begin{array}{l}\text { Fator da natureza física, química ou biológica responsável pela gênese de uma } \\
\text { doença ou infestação. }\end{array}$ \\
\hline Anamnese & Recordação de fatos que se passaram até o problema atual. \\
\hline Anamnese passiva & O consulente recorda os antecedentes. \\
\hline Anamnese ativa & O técnico interroga sobre os antecedentes. \\
\hline Carência & Período compreendido entre o último tratamento e a colheita. \\
\hline C. I. & Conceito inicial: critério inicial obtido pelas informações do rapport. \\
\hline Diagnóstico & Identificação da doença ou da infestação pelo conhecimento da etiologia. \\
\hline Etiologia & $\begin{array}{l}\text { Estudo das causas. É a ciência que trata das causas das doenças e infestações } \\
\text { quanto à natureza, evolução, classificação e relações com suscetiveis. }\end{array}$ \\
\hline Etologia & Estuda o comportamento dos seres vivos. \\
\hline Fenologia & $\begin{array}{l}\text { Estudo dos fenômenos periódicos da vida vegetal ou animal. Trata da regulação } \\
\text { de eventos biológicos periódicos em relação aos fatores ambientais chaves. }\end{array}$ \\
\hline Fitotoxicidade & Propriedade de uma substância de causar injúrias nos vegetais. \\
\hline F.P. & Ficha profissional. \\
\hline Gênese & Aparecimento. \\
\hline HPPA & $\begin{array}{l}\text { História pregressa do problema atual: relato dos fatos que precederam o } \\
\text { problema atual. }\end{array}$ \\
\hline IDA & $\begin{array}{l}\text { Ingestão diária aceitável: exprime a quantidade de um produto biologicamente } \\
\text { ativo, que pode ser ingerido diariamente pelo homem, sem que ocorram maiores } \\
\text { problemas de risco. }\end{array}$ \\
\hline Prognóstico & Previsão quanto ao desfecho do tratamento em relação ao destino do cultivo. \\
\hline Q. D. & Queixa e duração: motivo da consulta e duração do problema. \\
\hline Rapport & Chegada, primeiro contato com o consulente. \\
\hline S. I. C. & $\begin{array}{l}\text { Observação adotada no registro técnico, quando a informação é considerada de } \\
\text { grande valor. }\end{array}$ \\
\hline Semiologia & Ciência que estuda os sinais precoces das doenças e infestações. \\
\hline Semiotécnica & Conjunto de procedimentos semiológicos que objetivam o diagnóstico. \\
\hline
\end{tabular}


Segundo GUERRA \& SAMPAIO (1991) os conceitos construídos para a chamada semiotécnica agronômica contemplam dois momentos durante o exercício do receituário.

O primeiro momento seria dedicado a quatro procedimentos seqüenciais: o Rapport (abordagem), a queixa e a duração (Q.D.), a anamnese passiva e a ativa.

Em seguida, associado a uma "indispensável" visita a propriedade, o técnico estaria em condições de passar ao segundo momento de conclusão do diagnóstico e prescrição da receita.

O Rapport foi definido como a denominação dada ao primeiro contato entre o consulente e o técnico; geralmente caracterizada como uma conversa informal com o cliente, buscando uma visão sobre o nível de conhecimento do consulente e a linguagem mais apropriada para a comunicação. A partir desse contato o técnico construiria o chamado conceito inicial (C.I.) do seu cliente.

Na seqüência da atividade semiotécnica os autores indicam o momento da queixa e duração, ocasião em que o técnico deveria restringir-se a indagar sobre qual o problema a ser trabalhado (queixa) e desde quando ele passa a existir (duração).

O passo seguinte seria a do procedimento da anamnese passiva, momento em que o técnico passaria anotar todo o relato do problema oferecido pelo cliente, interferindo apenas para evitar "divagações na conversa".

Tais anotações seriam então retomadas no momento seguinte, para o exercício da anamnese ativa, ocasião em que o técnico interrogaria o cliente sobre os pontos antes apresentados espontaneamente.

Os tópicos sugeridos por GUERRA \& SAMPAIO (1991), para as questões a serem levantadas na anamnese ativa devem abordar: 
- Cultura - cultivar, área plantada, desenvolvimento, aspecto geral, culturas adjacentes, tratos culturais, adubação, solo limpo ou coberto (plantio direto alelopatias), agroquímica, potencialidade, etc;

- Pessoal - disponibilidade, treinamento, informação toxicológica, idade, estado de saúde, vínculo empregatício, relacionamento, etc;

- Equipamento - disponibilidade, operacionalidade, rendimento de trabalho, calibragem, etc;

- Instalações - local para armazenamento dos agrotóxicos, sumidouro, parque de abastecimento e lavagem de equipamento, residências, cercas, aguadas, cocheiras, galinheiros, currais, etc;

- Topografia e recursos naturais - relevo, matas, vida silvestre, cursos de água, etc;

GUERRA \& SAMPAIO (1991) detalhando o procedimento chegam a propor um roteiro de perguntas básicas a serem levantadas pelo técnico no momento da anamnese ativa, conforme mostra a figura 19 , a seguir. 


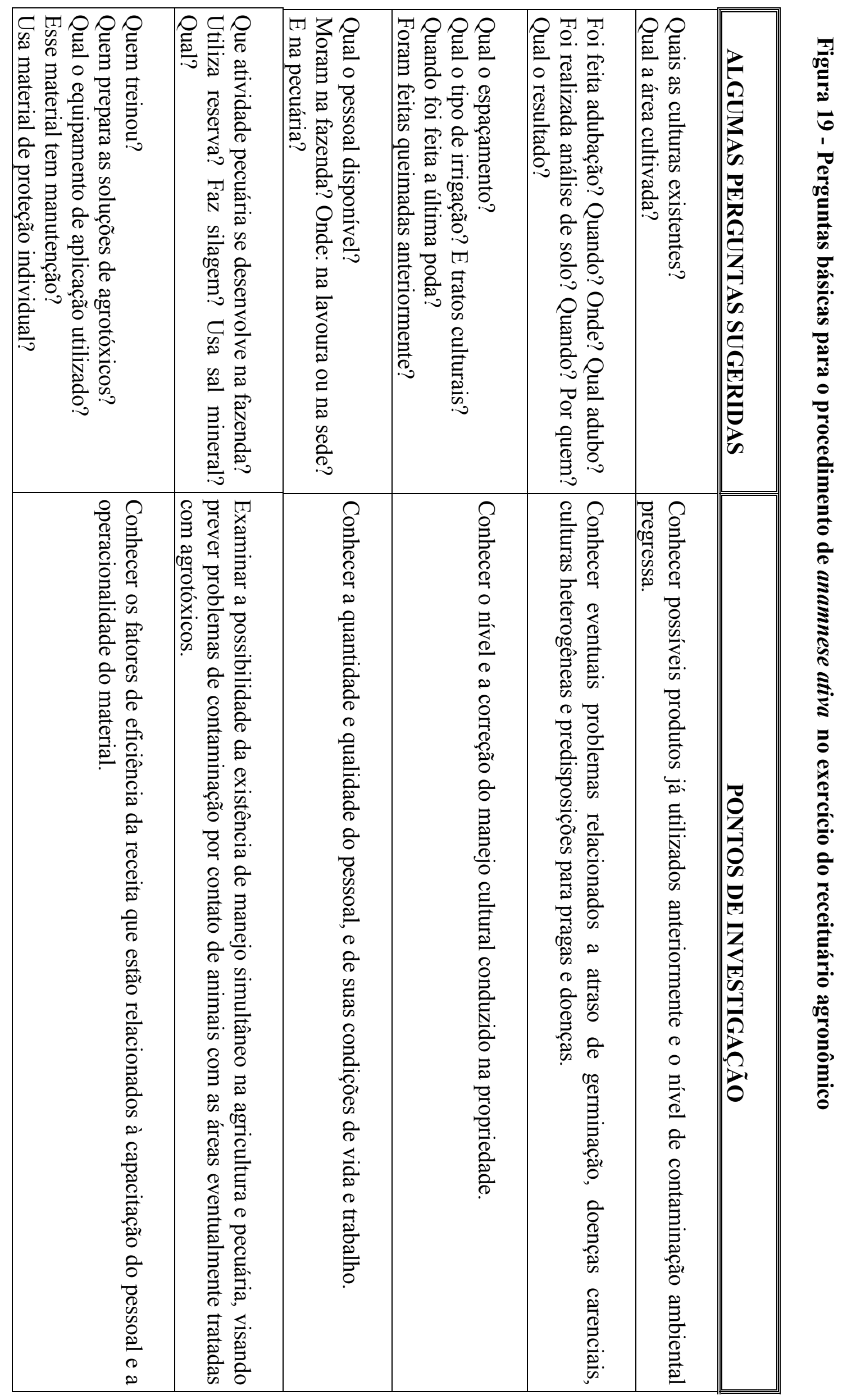




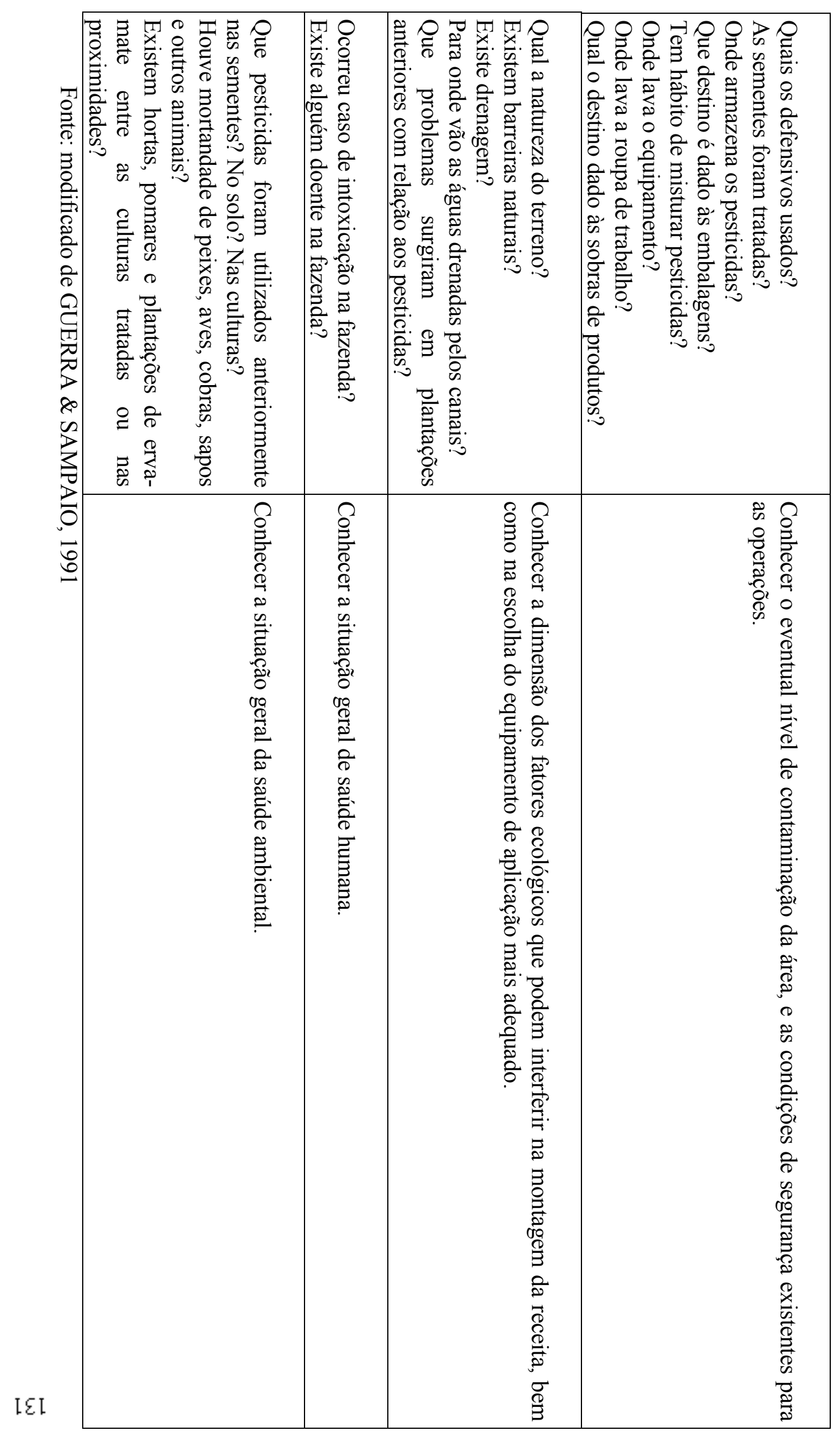


Ao final do primeiro momento na seqüência semiotécnica preconizada por Guerra \& Sampaio, o técnico já estaria em condições de avaliar o quadro geral do consulente, nos seguintes aspectos:

- nível de contaminação ambiental;

- nível de segurança das condições operacionais, de trabalho e de armazenamento de pesticidas;

- erros, deficiências, fatores limitantes com relação à escolha das formulações;

- condições econômicas para a viabilidade do receituário;

- fatores de eficiência a serem explorados; e

- informações que deverão ser prestadas além da receita.

Após esta primeira fase o passo seguinte deveria ser o da visita à propriedade; etapa esta colocada como "indispensável" pelos autores. É nesta ocasião que as informações levantadas na fase da entrevista inicial com o consulente estariam sendo conferidas em detalhes.

"....Assim, e só assim, o profissional terá a certeza dos fatos, a precisão dos dados, e conhecimento da verdadeira etiologia ou etiologias do problema, ou seja, o diagnóstico fiel" (GUERRA \& SAMPAIO, 1991:82).

O conjunto das informações obtidas pela entrevista com o consulente, e os da perícia de campo, ofereceriam então os subsídios necessários para que o técnico pudesse compor a "história pregressa do problema atual - HPPA", que seria a soma dos fatores antes levantados:

HPPA $=$ RAPPORT + Q.D. + Anamnese passiva + Anamnese ativa + C. I.

Onde: $\quad$ Q.D. = queixa e duração e

C. I. = conceito inicial

A "história pregressa do problema atual" passaria a ser então registrada em uma ficha de controle (F.C), compondo o J da ficha técnica da propriedade. (Figura 20) 


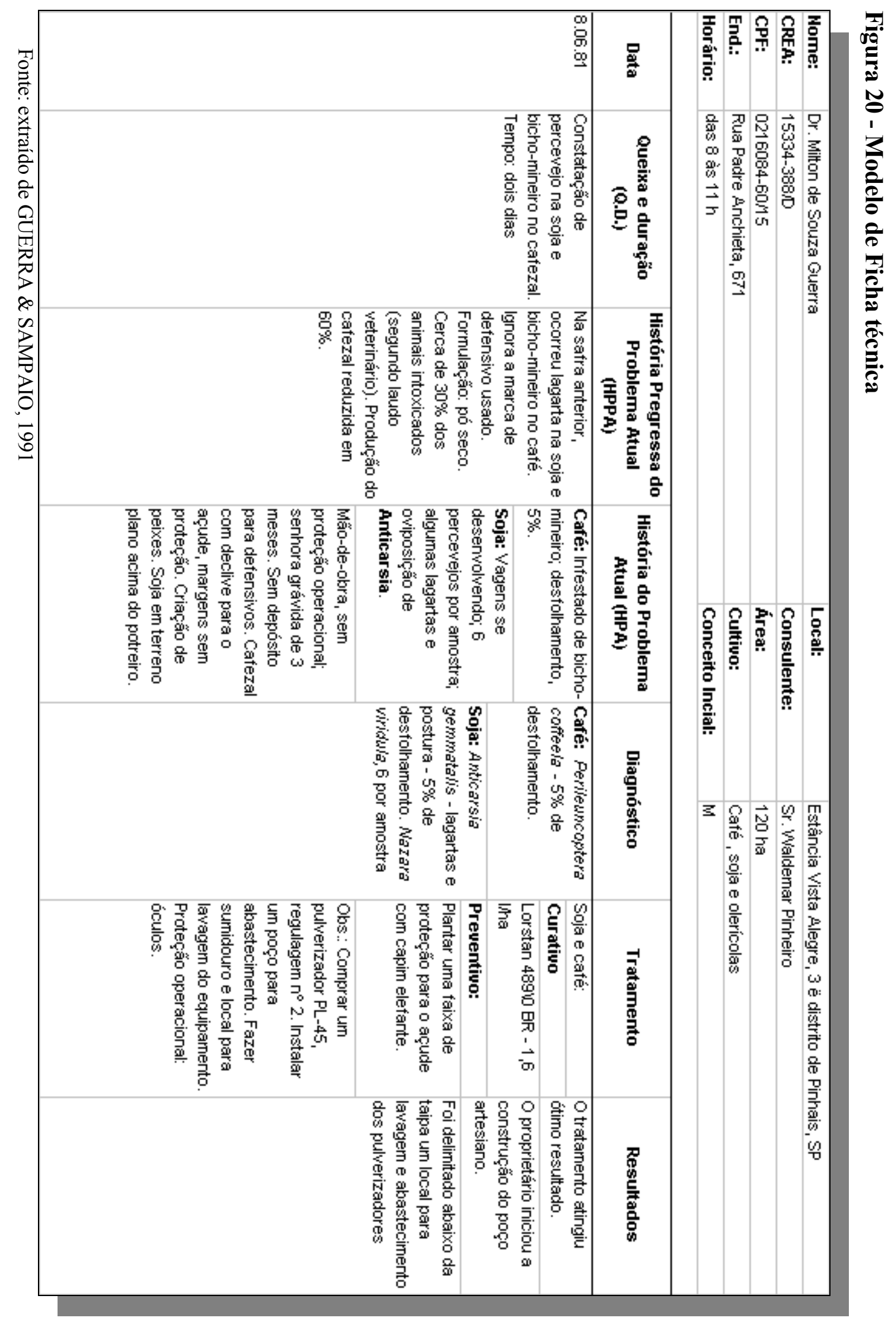


Para os autores proponentes da doutrina do receituário agronômico, a eficiência da prescrição técnica estaria na dependência de um conjunto de fatores que poderiam ser organizados em dois principais grupos (Figura 21).

\section{Figura 21 - Fatores determinantes da eficiência do receituário}

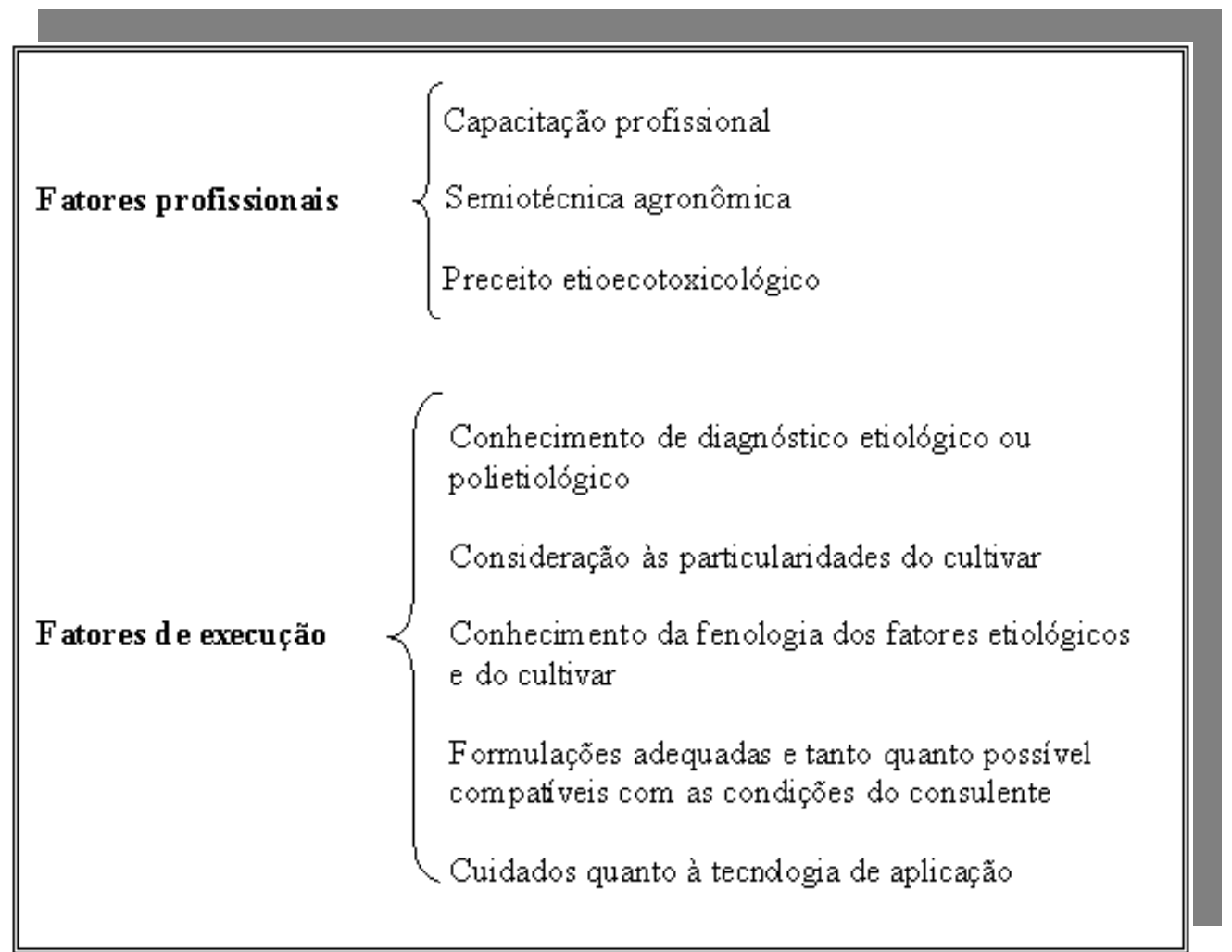

Fonte: GUERRA \& SAMPAIO, 1991

O reconhecimento das limitações técnicas dos engenheiros agrônomos no acompanhamento da dinâmica imposta pela indústria química, a partir do lançamento maciço de produtos no mercado, pode ser verificada na argumentação do Prof. Daiser Paulo Sampaio, em publicação destinada aos cursos de reciclagem e formação de agrônomos para atuação no exercício do receituário.

"A indústria oferece ao engenheiro agrônomo um grande número de opções de tratamento e controle de pragas e doenças.....compondo um arsenal de 4.000 formulações, para os diversos fins. Atualmente toda a propaganda de pesticidas é feita na intimidade da propriedade rural......Não constitui nenhuma novidade que, em 
inúmeros casos e em inúmeras regiões, os técnicos são os menos informados sobre produtos novos que, a cada dia, surgem em sua área de exercício profissional...

...Realmente, muito pouco acesso têm os engenheiros agrônomos à bibliografia especializada; isto faz com que os técnicos se transformem em meros orientadores, com base em informações impostas pelos fabricantes" (SAMPAIO, 1978:21).

Assim, a questão da capacidade profissional colocou-se como um dos fundamentos para o êxito do receituário, ao mesmo tempo em que se imaginou que o próprio exercício da atividade poderia proporcionar maiores facilidades no trato da tecnologia química, por parte do profissional atuante nas atividades de prescrição

"O exercício continuado do R.A. proporciona, ao profissional, possibilidade de memorizar rapidamente um grande número de princípios ativos, compatíveis com cada caso em particular..." (SAMPAIO, 1978:21).

O conhecimento e a aplicação dos procedimentos semiotécnicos também são assinalados como fatores profissionais a interfirir na eficiência do receituário. Mais uma vez é ressaltada a importância do estudo de cada caso, inclusive com as avaliações da perícia de campo.

"...não basta ao agrônomo conhecer os sintomas ou os sinais de ocorrência de doenças ou pragas na lavoura. É importante que dimensione sua distribuição e intensidade de ataque....Por meio da semiotécnica adequada busca-se o nível de controle...que é imprescindivel para um procedimento terapêutico técnico-cientifico, sem o qual o agrônomo estará agindo empiricamente, ao acaso, o que não é compatível com sua formação profissional.

Para tanto é indispensável a presença do agrônomo no campo, junto ao problema, para que tenha condições de avaliar a situação in loco" (GUERRA \& SAMPAIO, 1991:62). 
Em relação aos fatores de execução apontados como determinates da eficiência do receituário os autores apontam os três primeiros (diagnóstico, conhecimento da cultura a ser tratada e conhecimento dos eventos biológicos periódicos que regulam as plantas e também as pragas e doenças) como dependentes da ação direta da atuação do profissional, com base em sua capacitação técnica.

Quanto aos demais fatores de execução apontados (formulações adequadas e cuidados com a tecnologia de aplicação) o técnico deverá valer-se das informações oferecidas pelos fabricantes dos agrotóxicos, os quais fornecem tais indicações nas bulas dos produtos, complementando e traduzindo em linguagem compatível com o consulente as informações relevantes para atender a tais fatores.

$\mathrm{Na}$ doutrina difundida pelos proponentes do receituário agronômico já constava a identificação de requisitos básicos a serem considerados no exercício da prescrição técnica, sob os quais existiriam limitações na escolha do recurso adequado para enfrentamento do problema de manejo das pragas e doenças.

SAMPAIO \& GUERRA, ao discutirem no "1 $^{\circ}$ curso sobre fundamentos do receituário agronômico" o contexto de aplicação do receita, apontavam 5 principais fatores como "limitantes da prescrição técnica", são eles:

- fatores econômicos: os aspectos econômicos da cultura e o poder aquisitivo do consulente vão determinar, por exemplo, a escolha da formulação mais adequada, tendo em vista as diversas opções existentes no mercado.

- fatores materiais: tipos de equipamentos e instalações disponíveis, a influenciar os padrões de segurança e eficiência agronômica atribuídos ao uso da tecnologia química.

- Fatores pessoais: o quadro de pessoal disponível para o tratamento a ser efetuado, e o nível de capacitação das equipes, são fatores limitantes a influir na 
prescrição. "Cabe ao técnico ponderar estes fatores e receitar nas dimensões exeqüíveis do problema."

- Fatores ecológicos: a topografia da região, os circuitos e as direções dos cursos de água, a natureza da vegetação nativa predominante, a natureza da fauna existente, são alguns dos aspectos a influir na prescrição de determinada técnica de controle de pragas.

- Fatores de contaminação ambiental pregressa: a receita agronômica deveria posicionar-se com base na contaminação ambiental pregressa (produtos anteriormente utilizados na região) para verificar e avaliar as possibilidades de sinergismos, investigar a eficiência obtida nas eventuais aplicações anteriores, bem como a ocorrência dos casos de resistência.

Mais recentemente, em publicação do ano de 1991, sobre o mesmo tema, Guerra \& Sampaio agregam mais um aspecto identificado como limitante da prescrição técnica: o fator legislativo.

"A nova atividade oferecida ao engenheiro agrônomo (receitar agronomicamente) exige do técnico uma postura responsável e atenta aos princípios que regem a legislação sobre o assunto. Qualquer erro de prescrição coloca o profissional em sério envolvimento com a Justiça, processos, código de ética, etc....(GUERRA \& SAMPAIO, 1991: 56).

Ao lado dos fatores acima mencionados os autores da doutrina inspiradora do receituário agronômico também conceberam uma rede de recursos logísticos apontada como fundamental para o exercício efetivo do receituário agronômico.

Esta rede de apoio operacional contaria basicamente com a atuação das instituições oficiais e órgãos de pesquisa, extensão, fiscalização, e de apoio legal (Figura 22). 
Figura 22 - Apoio logístico ao receituário agronômico - subsídios

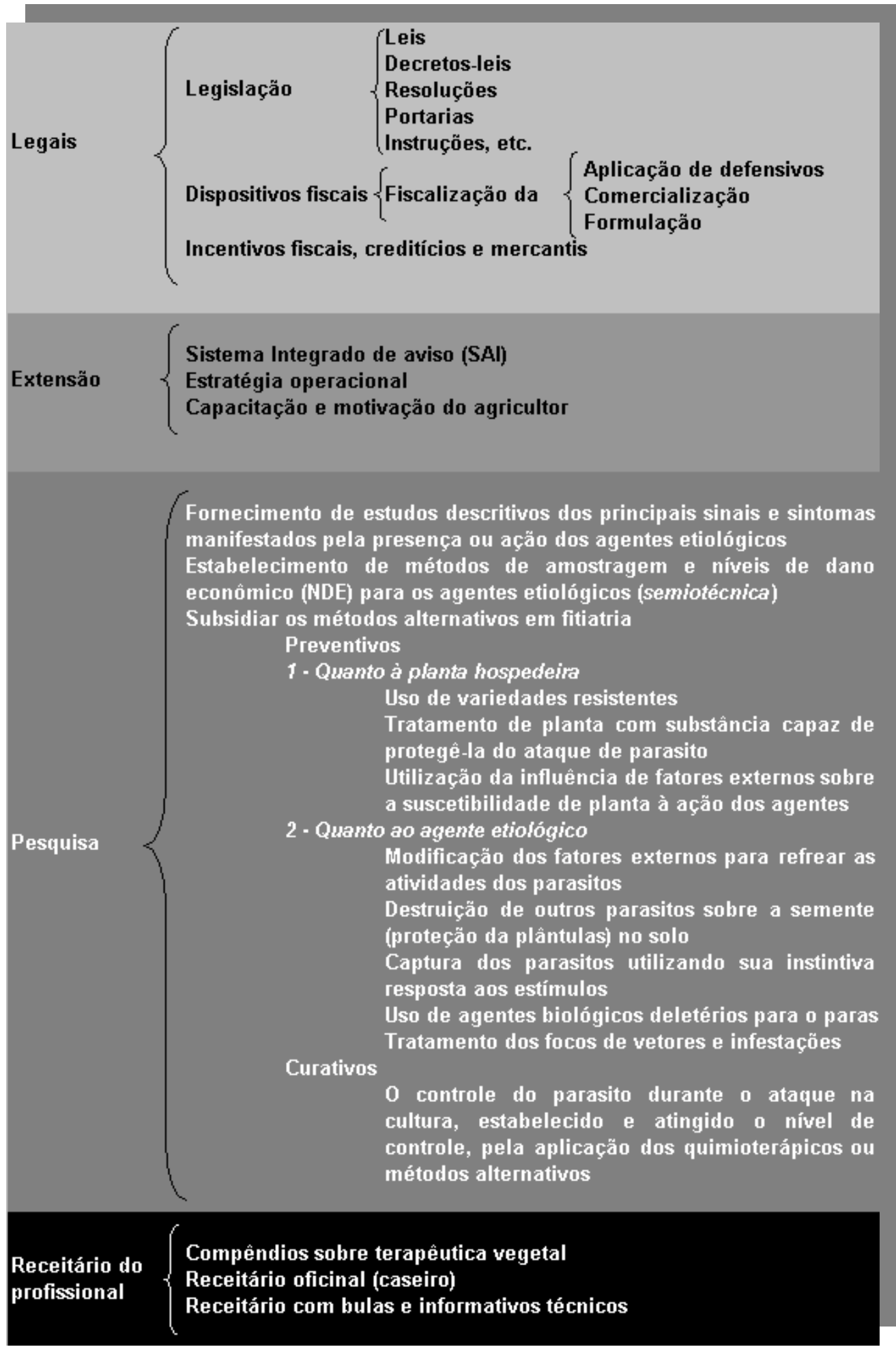

Fonte: GUERRA \& SAMPAIO, 1991. 


\section{PERDENDO O PONTO DA RECEITA: AS CONTROVÉRSIAS MODIFICANDO A IDÉIA INICIAL}

\section{1. O estabelecimento do debate}

Ao final da década de 70 as repercussões da iniciativa desenvolvida pelo Banco do Brasil na adoção do receituário agronômico em suas operações de crédito rural, somadas às pressões crescentes promovidas pelos movimentos de combate ao uso indiscriminado dos agrotóxicos em todo o país acabaram por induzir a ação governamental na questão.

Neste contexto o Ministério da Agricultura, através da Portaria $n^{\circ}$ 347, de 07 de novembro de 1980, institui oficialmente o receituário agronômico, não obstante o posicionamento de suas autoridades, até então contrárias ao sistema de controle proposto (PINHEIRO, 1993).

Os critérios adotados pela legislação recém criada apresentavam-se, de certa forma, como menos rígidos em comparação ao sistema precursor implantado no âmbito do Banco do Brasil.

A medida instituída pelo Banco do Brasil preconizava a necessidade de receita para qualquer produto, independentemente de seu grau de toxicidade.

Já a adoção do mecanismo pelo Ministério da Agricultura ficou restrita aos produtos das classes toxicológicas I e II (altamente e medianamente tóxicos, conforme 
classificação à época), deixando os produtos classes III e IV com venda livre, independente de responsabilidade técnica.

Este fato já indicava o caráter conflituoso do processo de adoção e implantação do sistema.

“A exigência de RA do Banco do Brasil, válido para todo o país, era para todo e qualquer produto, independentemente de seu grau de toxicidade. Isto era bastante lógico, pois um produto muitas vezes não-tóxico necessitava de uma carga extra de conhecimentos técnicos, para sua aplicação. Já o receituário do Ministério da Agricultura era somente para os produtos de classe toxicológica I e II, ficando a venda livre para as classes III e IV" (PINHEIRO, 1993:92).

A rigor, a Portaria n³47/80 do Ministério da Agricultura fazia referência não só ao instrumento da receita como medida de controle, mas citava também o "Projeto fitossanitário". A apresentação de qualquer um destes instrumentos era condição obrigatória para que o usuário final pudesse ter acesso à compra dos produtos.

Isto de certa forma refletia o embate que se travava entre as partes opostas na questão dos agrotóxicos. De um lado os mais críticos sobre os benefícios dos agrotóxicos defendiam a adoção do receituário, de outro, a indústria química e a parte da comunidade técnica ligada a esse setor defendiam a adoção do "projeto fitossanitário".

Em reportagem de julho de 1979 a revista "Química e Derivados" traz uma entrevista realizada com vários representantes das empresas de agrotóxicos. É possível desenhar um cenário bastante claro sobre as posições em relação à proposta do receituário agronômico, a partir dos argumentos apresentados na citada reportagem:

"Outro projeto a não contar com muita simpatia por parte dos fabricantes é o Receituário Agronômico, já utilizado no Rio Grande do Sul e por cuja regulamentação as associações de agrônomos vêm lutando" (Química e Derivados, julho, 1979:14). 
Na palavra do diretor de planejamento de uma das grandes empresas do setor, à época, a Companhia Nacional de Defensivos Agrícolas (CNDA), pode-se observar os argumentos sobre a suposta inadequação do termo "receituário", sobre uma deficiência potencial do instrumento para atender às necessidades impostas pela dinâmica dos processos de infestação pelas pragas; e ainda uma outra linha de argumentação que se baseia na constatação de que a comunidade técnica não se encontrava preparada para o exercício do receituário agronômico e sobre o despreparo dos agrônomos. Este último argumento parece bastante contraditório, uma vez que se reconhecia uma eventual deficiência dos agrônomos para o exercício da prescrição criteriosa dos produtos, entretanto a "venda sem controle" certamente não sanearia tal deficiência.

"...o setor não é contrário ao Receituário Agronômico, embora receituário não seja a palavra adequada, pois é uma atividade privativa dos médicos. A receita é dada depois de constatada a doença. Ora, surtos de praga aparecem da noite para o dia. Um surto de lagarta, por exemplo, devora uma lavoura inteira em poucas horas. Além do mais, os defensivos agrícolas são produtos complexos e há necessidade de reciclagem dos agrônomos, para sua atualização. Isso, quando falta material humano na área de agronomia.

....Agora, esse negócio de receita não existe em nenhum lugar do mundo. E, em razão do contexto cultural e geográfico, não sei se o Brasil tem condições de inovar nesse campo" (Química e Derivados, julho, 1979:14).

Carlos Alves Seixas, da empresa Nortox, entendia o receituário como uma medida parcial e pouco prática, mas reconhecia a importância de que um mesmo técnico viesse a prescrever a receita e também acompanhar todo o processo. Neste sentido sua argumentação também se alinhava a de outros do setor das empresas, os quais defendiam que a atividade de indicação técnica dos agrotóxicos deveria ser restrita a um grupo especializado de profissionais da agronomia, os chamados "fitossanitaristas". Nesta proposta a idéia de que tal grupo ficaria basicamente restrito aos profissionais das empresas de agrotóxicos, desencadeou um amplo processo de reação por parte da 
corporação agronômica, especialmente representada pelos componentes do sistema CONFEA-CREAs.

“...Além disso, a defesa vegetal é uma especialidade dentro do campo agronômico. Assim só poderão definir tratamentos rem relação a esta ou aquela cultura os agrônomos fito-sanitaristas. Quando se leva para todo o profissional de agronomia a oportunidade de receitar, está se correndo um risco técnico" (Química e Derivados, julho, 1979:14-18).

Uma visão ainda mais cética sobre o sucesso e a aplicabilidade da idéia do receituário agronômico foi apresentada na citada reportagem, a partir da argumentação do então gerente de setor da divisão de defensivos da Bayer do Brasil S.A.:

"...Pode-se restringir a venda, mas restringir o uso é muito mais prático e eficiente...No Rio Grande do Sul, o agrônomo dá a receita sem sequer conhecer o agricultor. Muitas vezes, o próprio revendedor é quem pega a receita com o agrônomo. Isso acaba, inclusive, aumentando os custos do próprio agricultor", (Química e Derivados, julho, 1979:14-18).

Mas a posição dos defensores da idéia do receituário, desde o início dos debates, já sinalizava para a necessidade de entender a proposta não como um simples sistema de "vendas sob receitas", mas a proposta contemplava a implantação de um sistema amplo de atividades na questão dos agrotóxicos, envolvendo desde o aperfeiçoamento dos processos de análise toxicológica dos produtos, o aparelhamento do estado para processar corretamente as informações de registro, o incremento dos serviços de assistência técnica e extensão rural, o desenvolvimento da pesquisa direcionada para práticas alternativas de combates às pragas e doenças, até o estabelecimento de um sistema de fiscalização efetiva dos insumos propriamente dito.

Estes pontos podem ser observados na argumentação de um dos dirigentes da Associação de Engenheiros Agrônomos do Estado de São Paulo, Moacir José Costa Pinto, em reportagem à revista "Química e Derivados", em julho de 1979. 
"... a Associação dos Agrônomos vem promovendo uma grande campanha para a legalização e regulamentação do que, talvez, seja o projeto mais caro de sua vida: o Receituário Agronômico, o qual restringiria o uso inadequado dos defensivos agrícolas, pois os produtos, principalmente os mais perigosos, não poderiam ser aplicados sem ser devidamente receitados por um engenheiro agrônomo, fornecendo subsídios ao agricultor para sua aplicação correta.

...Embora o Receituário esteja provocando polêmicas entre os fabricantes de defensivos agrícolas, para Moacir, não adianta discutir apenas o seu aspecto formal, pois não é a receita a única base do projeto, e sim todo um complexo de atividades, desde os estudos toxicológicos dos produtos químicos até os estudos das técnicas agrícolas mais adequadas à cultura em questão...... importante é deixar claro que nós não pretendemos, simplesmente, assinar receitas" (Química e Derivados, julho, 1979:28).

Para tentar deter o crescimento da idéia do receituário agronômico, os representantes da indústria dos agrotóxicos desenvolveram a proposta do "Projeto Fitossanitário". Mas qual seria a diferença entre as duas propostas?

Em reportagem da revista "Atualidades Agropecuárias", do ano de 1980, a discussão sobre estas duas propostas é apresentada:

"Uma questão de terminologia semântica? Talvez. Mas, o fato é que o receituário agronômico tem criado várias polêmicas, e propiciado o aparecimento, até mesmo, de projetos similares a ele. É o caso do plano fitossanitário..." (Atualidades Agropecuárias, 1980:21).

Trazendo a visão da indústria na citada reportagem, Luiz Carlos Ferreira Lima , representante de uma das empresas atuantes no setor, aponta as limitações contidas na proposta do receituário agronômico, e ao mesmo tempo indica o "projeto fitossanitário" como a solução mais adequada para fazer frente aos problemas decorrentes do uso de agrotóxicos. 
"...qualquer produto, por melhor que seja recomendado, se não for aplicado por pessoa habilitada, poderá provocar toda uma série de perdas e acidentes. Afinal, a aplicação se constitui no momento de maior risco, quando é empregado o defensivo agrícola. Analisando-se, então, o problema sob este ângulo, teoricamente, até se poderia aceitar o receituário agronômico. Mas, na prática, seria difícil sua viabilidade. Pois não atenderia aos objetivos desejados, isto é: os de preservar a produção nacional sem causar danos ao homem, aos animais e ao ambiente" (Atualidades Agropecuárias, 1980:21).

O ponto básico de argumentação do representante da indústria sobre a inadequação do receituário agronômico repousava no fato de que a simples exigência de intermediação técnica no momento da prescrição não garantiria o "uso adequado" do produto, pois no momento da aplicação, a presença do técnico não estava necessariamente sendo exigida.

"...A receita é entendida como parte de um processo em que o técnico, ao se defrontar com um problema fitossanitário já existente, faz o seu diagnóstico. Identificando as causas, ato contínuo, ele prescreve as medidas de controle mais adequadas ao caso. Agora, esperar que esse mesmo técnico supervisione os trabalhos de aplicação dos defensivos, nas atuais condições brasileiras, é estar inteiramente fora da realidade agrícola em que vivemos" (Atualidades Agropecuárias, 1980:21).

Outra linha de argumento contra o receituário agronômico fazia referência ao não atendimento deste instrumento nas situções emergenciais criadas na dinâmica do processo produtivo agropecuário e florestal, onde não estava garantida a presença constante de um técnico capacitado para o enfrentamento das questões fitossanitárias nos locais de produção.

"... a implantação do receituário agronômico poderá trazer sérias conseqüências ao agricultor, concernentes à aquisição dos produtos fitossanitários de que necessita face às dificuldades que serão encontradas. Exemplo disso são: a necessidade de um técnico presente quando da ocorrência do problema fitossanitário; a urgência de 
liberação do crédito agrícola para a aquisição dos defensivos e a disponibilidade dos produtos recomendados nas proximidades da propriedade agrícola. E mesmo assim: ainda que os itens referidos possam ser atendidos com presteza necessária, dificilmente haverá em disponibilidade, um técnico para orientar as aplicações dos produtos. Por isso nasceu o projeto técnico fitossanitário" (Atualidades Agropecuárias, 1980:21).

A proposta de "projeto fitossanitário" apresentada pelos representantes da indústria de agrotóxicos baseava-se, de forma geral, no desenvolvimento de campanhas de "uso adequado", na formação de aplicadores habilitados, e no estabelecimento de processo de apresentação de projeto técnicos prevendo o uso de agrotóxicos, por ocasião das solicitações de financiamento agrícola, conforme acentua Ferreira Lima, na citada reportagem.

"A indústria, através da Andef, tem feito campanhas de ensino ao homem rural....A idéia é capacitar o aplicador de defensivos. É dar-lhe habilitação...Fica claro, portanto, que o projeto técnico fitossanitário dará, ao agricultor, mais elementos do que um simples rótulo de produto para orienta-lo na aplicação...

...O engenheiro agrônomo, devidamente habilitado e, conhecedor das condições locais da cultura em estudo, poderá, por antecipação ao plantio, propor um projeto técnico de controle fitossanitário que melhor atenda às diversas alternativas de pragas e doenças que possam ocorrer. Poderá, também, através do projeto, fornecer ao agricultor, uma justificativa para a aquisição do financiamento de que necessite e, conseqüentemente, antecipar, pelo menos, parte da compra dos defensivos indispensáveis" (Atualidades Agropecuárias, 1980:21).

Enquanto os propositores da idéia do receituário agronômico seguiam na busca da construção de uma doutrina técnica para a prática da prescrição, abrindo inclusive a possibilidade de discussão e aplicação de outras práticas não-químicas para o manejo e controle de pragas e doenças, os defensores do "projeto fitossanitário" insistiam em outro caminho. Na proposta do projeto técnico as prescrições seriam feitas "a priori", 
no momento de planejamento de uma cultura, mais precisamente na ocasião em que o agricultor apresentasse um "plano de cultura" junto aos órgãos de liberação do crédito rural. Neste contexto não havia muito espaço para a exploração de outras eventuais técnicas existentes para o controle das pragas e doenças. A lógica montada era simples: o agricultor ao apresentar um plano de cultura, deveria também contemplar um projeto para o controle fitossantário. Neste projeto a terapia indicada contemplaria basicamente o manejo químico e as quantidades presumidas de agrotóxicos a serem utilizadas eram então dimensionadas e seus valores correspondentes eram adicionados ao projeto de financiamento.

Todavia, não obstante o caráter reducionista e burocratizante da proposta de projeto fitossanitário, seus defensores apresentavam uma linha de argumentação oposta às reais características da proposta, numa evidente distorção do debate, conforme se pode notar no depoimento apresentado pelo então diretor executivo da ANDEF, Régis Rahal, em reportagem da revista "Agricultura de Hoje", de junho de 1980.

"...apesar de tudo o que dissemos e de tudo o que fizemos até aqui, estamos absolutamente convencidos de que o uso adequado nõa se resolve apenas com palavras. Nesse sentido, acreditamos que o receituário agronômico que se pretende impor ao agricultor brasileiro não vai solucionar essa questão. A nosso ver, a receita conforme a proposta original, tem-se limitado exclusivamente à transcrição das normas contidas na bula ou no seu rótulo. Depois, tira o engenheiro agrônomo do campo.

...Por isso, a ANDEF está propondo a instituição, como norma legal, do Projeto Técnico Fitossanitário, segundo o qual só poderiam ser entregues ao consumo os defensivos de acordo com a classificação a ser estabelecida pelo Ministério da Agricultura, mediante apresentação de Projeto Técnico Fitossanitário, firmado por engenheiro agrônomo, de acordo com a destinação do produto.

...Cada projeto deverá conter, além dos itens essenciais quanto à recomendação dos produtos, os seguintes: momento e condições de aplicação; equipamento a ser 
utilizado; o intervalo em dias entre a última aplicação e a colheita; a fitotoxicidade à cultura a ser protegida e às outras culturas próximas; a toxicidade da formulação prescrita; a proteção dos aplicadores e demais pessoas envolvidas; e o destino às embalagens vazias, bem como a guarda das embalagens não utilizadas" (Agricultura Hoje, 1980:45).

A tentativa de conferir à proposta do "projeto fitossanitário" uma qualidade dinâmica e legitimidade não compatível com seu conteúdo real também é exercitada nas argumentações colocadas no debate pelo então dirigente da ANDEF.

"...o importante nessa proposição é que o engenheiro agrônomo vai estar, como aliás deve estar, no campo, em contato com o lavrador, contribuindo efetivamente para o desenvolvimento da agricultura brasileira. Adicionalmente, a instituição do Projeto Técnico Fitossanitário ensejará a criação de uma nova profissão, a de aplicador dos defensivos agrícolas nas lavouras. Do ponto de vista social, será uma grande conquista, na medida em que melhorará as condições de vida do trabalhador rural" (AGRICULTURA HOJE, 1980:46).

Ao menos um ponto em comum surgia na argumentação entre os debatedores da questão do receituário: a necessidade de investimentos na formação dos aplicadores de agrotóxicos. Um dos defensores desta linha foi Waldemar Ferreira de Almeida, médico toxicologista que exerceu um papel importante na formação de massa crítica junto ao meio técnico-científico, na construção de uma visão mais crítica sobre os problemas de saúde ocupacional e ambiental envolvidos no uso de agrotóxicos. Em reportagem da revista "Atualidades Agropecuárias", de abril de 1980, intitulada "Ensinar ou proibir?", o Dr. Waldemar expõe seus argumentos em favor da adoção da figura do "aplicador habilitado".

"Os aplicadores de defensivos precisam saber o que estão aplicando. E o que tenho observado no interior é um fato curioso: os indivíduos não recebem nenhuma informação dos capatazes, chefes ou fazendeiros. Estes explicam que, se os aplicadores forem notificados do perigo do produto, vão embora: não querem fazer o 
trabalho. Dessa forma, os defensivos são aplicados de forma prejudicial aos aplicadores, à sua família e aos que estão mais próximos. Falta de informação é lamentável e malévola.

Há rótulos. É fato. Mas, inúmeras vezes, as pessoas que aplicam defensivos não sabem ler e fazer tudo sem esclarecimento. Por outro lado, países desenvolvidos tem aplicadores profissionais de pesticidas....

....Todos são submetidos a um curso de treinamento e, depois, a um exame de capacitação ou de habilitação. Esses trabalhadores, nesses países, tem uma caderneta de trabalho e uma cédula de identidade. Essas pessoas são as que tem autorização para comprar e aplicar os produtos tóxicos..." (Atualidades Agropecuárias, 1980:1617).

Mas se havia consenso quanto a carência de formação de pessoal capacitado para uma atuação responsável nas atividades de aplicação, o mesmo não ocorria na discussão em torno da adoção do receituário e de sua contraproposta: o projeto técnico fitossanitário.

GUERRA (1982), já observava que o Projeto Fitossanitário propunha um programa de tratamento baseado na fenologia (estudo dos eventos biológicos periódicos) da cultura e dos agentes etiológicos (doenças e pragas); apoiando-se portanto, em suposições. Tal projeto, "poderia ser válido para orientação do técnico, mas exatamente perigoso na mão de leigos. O agricultor, de posse de um projeto, é induzido a realizar tratamentos, na maior parte das vezes, inoportunos ou desnecessários quando não, pelas características da lavoura, contra-indicados pelos seus efeitos danosos diretos e colaterais" (GUERRA, 1982:175).

Um quadro estabelecendo um paralelo entre o que deveria constituir um receituário agronômico e suas diferenças em relação a um simples projeto fitossanitário, é apresentado a seguir (Figura 23). 
Figura 23 - Aspectos comparativos entre o "receituário agronômico "e o "projeto fitossanitário"

\begin{abstract}
RECEITUÁRIO AGRONÔMICO
estuda, investiga, analisa as soluções para um problema fitossanitário especificamente;

apoia-se em fatos;

objetiva reduzir o consumo de agrotóxicos;

compatibiliza o uso de agrotóxicos com o nível cultural do aplicador, sobretudo protegendo-o;

reduzindo o consumo de agrotóxicos, reduz a contaminação ambiental;

compatibilizando o uso de agrotóxicos com as condições do agricultor, protege a sua saúde;

reduzindo o consumo de agrotóxicos a um mínimo necessário e indispensável, reduz os custos de produção - a estimativa de consumo é função da distribuição do agente etiológico;
\end{abstract}

fixa o Eng $^{\circ}$ Agrônomo no campo, pois uma receita só é considerada válida e honesta tendo o técnico realizado os exames "in loco";

propicia uma assistência personificada ao agricultor;

atende aos interesses de produção, de saúde humana, saúde animal e ambiental, através da redução no consumo de agrotóxicos;

\section{PROJETO FITOSSANITÁRIO}

preconiza, calcula, quantitativos de insumos para a utilização em safras, generalizadamente;

apoia-se em suposições;

objetiva assegurar a utilização de agrotóxicos mesmo que desnecessário;

pelo seu caráter despersonificado, não leva em conta a integridade hígica do aplicador;

incitando o consumo de agrotóxicos, assegura a continuidade da contaminação ambiental;

propiciando a utilização constante de agrotóxicos, expõe permanentemente o agricultor a riscos;

induzindo o consumo de agrotóxicos através de tratamentos programados, aumenta o custo de produção; a estimativa de consumo é função da área cultivada;

é elaborado em gabinete, baseado em informações cadastrais (fenologia dos agentes etiológicos, recomendações de pesquisa) e não em preceitos técnicos científicos emanados de perícia "in loco";

proporciona uma assistência mensal aos agricultores;

atende aos interesses das indústrias e comércio de agrotóxicos que terão seus estoques programados e vendas estimuladas;

Fonte: modificado de GUERRA, M.S. Receituário Agronômico: implantação e operacionalização. In: Francisco GRAZIANO NETO, coord. Uso de agrotóxicos e Receituário Agronômico. São Paulo. Agroedições, 1982. p.p.172179

No decorrer dos debates sobre qual instrumento melhor atenderia as necessidades de controle do uso indiscriminado, várias denúncias de impactos ambientais e à saúde dos trabalhadores chegavam às manchetes dos meios de comunicação. Vários argumentos eram divulgados, dando conta do potencial positivo passível de ser explorado pela instituição do receituário agronômico, colaborando dessa forma para o crescimento do movimento em favor da adoção desse instrumento. 
"O movimento para instituição do receituário agronômico não foi desencadeado pelo mau uso dos defensivos (desperdício econômico) ou os resíduos nos alimentos. Segundo, um estudo da Fundação Getúlio Vargas, a causa está no agravamento da questão toxicológica, ligada ao aplicador de defensivos e à poluição ambiental provocada pelos pesticidas químicos" (Revista Raízes, dezembro, 1980:68).

Estas afirmações dão início a um artigo publicado na revista "Raízes", em dezembro de 1980, denominado "Só com receita", onde se buscava fazer um levantamento geral dos resultados práticos já alcançados pela instituição do receituário agronômico, nas regiões em que o instrumento já vinha sendo praticado.

Mas o debate em torno do mecanismo a ser adotado não durou muito tempo, ao menos sob o ponto de vista legal, pois a Portaria $n^{0} 347 / 80$, do Ministério da Agricultura, que contemplava o receituário agronômico e também o "projeto fitossanitário", logo foi substituída por outro dispositivo legal.

Em janeiro de 1981 o Ministério da Agricultura aprova a Portaria nº07, a qual, segundo PINHEIRO et al. (1993), corrigia os erros de estrutura e ortografia contidos no texto do dispositivo anterior; além disto a nova redação excluía a figura do "projeto fitossanitário", firmando apenas a "Receita Agronômica, fornecida por Engenheiro Agrônomo registrado no CREA", como requisito para a comercialização de produtos classificados nas categorias I e II (altamente tóxicos e medianamente tóxicos conforme classificação toxicológica estabelecida à época) diretamente aos usuários finais.

Em fevereiro do mesmo ano o Ministério da Saúde aprova a Portaria ${ }^{\circ}$ 02/DISAD, promovendo mudanças na classificação toxicológica dos produtos; classificação esta que até então era baseada em Portaria anterior $\left(n^{\circ}\right.$ 004, da Secretaria Nacional de Vigilância Sanitária, SNVS, do Ministério da Saúde). Nesta classificação anterior cerca de 96 por cento dos produtos pertenciam às classes I e II, e portanto deveriam ser controlados pelo instrumento da receita. 
Mas a nova portaria modifica substancialmente a distribuição dos agrotóxicos pertencentes entre as classes I e II, diminuindo a abrangência da medida de controle preconizada na portaria $n^{\circ} 007$ que estabelecia a necessidade de receita para a compra de produtos destas classes.

"Não foi surpresa ver a classificação toxicológica ser modificada, em fevereiro de 1981, por obra e arte da Andef. Assim a quase totalidade dos produtos de classes I e II passaram para as classes III e IV" (PINHEIRO et al, 1993:93).

\section{2. As dificuldades de implantação e operação do sistema}

Diversas foram as tentativas e dificuldades para a implantação do receituário agronômico, o qual já se exercitava no âmbito local onde surgiu a proposta, no Rio Grande do Sul; mas enfrentava grandes problemas na expansão para os demais estados e para a esfera federal.

O quadro a seguir, desenhado a partir de subsídios recolhidos em reportagem publicada na revista "RAÍZES", em 1980, descreve resumidamente alguns pontos colocados como obstáculos para a implementação inicial do receituário agronômico , e aponta a visão de seus proponentes quanto às perspectivas oferecidas pela idéia de implantação do instrumento. 
Figura 24 - Obstáculos e perspectivas inicias para a implantação da proposta de receituário agronômico , Brasil - 1979-80.

\begin{tabular}{|c|}
\hline OBSTÁCULOS \\
\hline $\begin{array}{l}\text { - pacote agrícola em fins de } 1979 \text {, preconizando a agilização da liberação dos } \\
\text { financiamentos do crédito rural; }\end{array}$ \\
\hline $\begin{array}{l}\text { - continuava existindo a possibilidade de venda de defensivos diretamente ao } \\
\text { consumidor por qualquer um dos elos da comercialização, isto é, fabricantes, } \\
\text { distribuidores, revendedores e cooperativas; }\end{array}$ \\
\hline $\begin{array}{l}\text { - a antecipação das compras, prática tradicional entre os agricultores em fase de } \\
\text { pressão inflacionária, como forma de reduzir os custos de produção das culturas. } \\
\text { Acrescente-se que essa necessidade do produtor é habilmente explorada mediante a } \\
\text { oferta de descontos pelos agentes de vendas da indústria de defensivos, no sentido de } \\
\text { garantir a participação no mercado; }\end{array}$ \\
\hline PERSPECTIVAS \\
\hline $\begin{array}{l}\text { - a capacitação dos profissionais para a emissão de receitas deverá ser realizada de } \\
\text { forma sistemática; }\end{array}$ \\
\hline
\end{tabular}

- $\quad$ as campanhas de divulgação das normas e das medidas de prevenção deverão ser permanentes;

- como requisito à implantação do receituário agronômico deveremos ter uma nova classificação toxicológica dos produtos;

- o receituário influenciará a área de pesquisa, aprofundando os conhecimentos sobre novos tipos de controle de pragas e doenças;

Fonte: Revista RAÍZES, dezembro, 1988:68-69

A implementação oficial do receituário agronômico no estado do Rio Grande do Sul deu-se no ano de 1982, a partir da aprovação de vários atos legais tratando da matéria, a saber: 
- Decreto $n^{0}$ 30.781: O Governo do Estado autoriza a suspensão da assistência técnica oficial ao produtor rural que adquirir e utilizar defensivos agrícolas sem receituário agronômico regular ou descumprir as especificações nela contidas

- Decreto $\mathrm{n}^{\mathrm{0}}$ 30.787/82: Pró́be a utilização de defensivos clorados no Estado, ressalvadas algumas exceções específicas.

- Portaria SSMA/AS n ${ }^{\circ}$ 01/82: Apresenta a listagem de inseticidas/acaricidas de uso proibido no Estado

- Decreto $\mathrm{n}^{\circ}$ 30.811: Institui o receituário agronômico e obriga o cadastramento das empresas de defensivos junto aos órgãos fiscalizadores

- Portaria SSMA/SA no 02/82: Estabelece as especificações técnicas mínimas, necessárias à implementação do receituário agronômico

- Lei $\mathrm{n}^{\circ}$ 7747, de 22 de dezembro de 1982: Dispõe sobre o controle de agrotóxicos e outros biocidas, homologando os decretos anteriores, passando a exigir o receituário agronômico para qualquer defensivo agrícola registrado no Ministério da Agricultura, independentemente da quantidade ou da classificação toxicológica

A quantidade de dispositivos legais aprovados no Rio Grande do Sul, tratando da questão dos agrotóxicos, no ano de 1982, foi resultante de um processo intenso de debates públicos e movimentações promovidas por ambientalistas de todo o estado.

Um dos participantes desse movimento foi Antenor Ferrari, advogado, deputado estadual pelo PMDB, fundador da Comissão de Direitos Humanos do Legislativo Gaúcho e co-autor da lei estadual dos agrotóxicos no Rio Grande do Sul. Em publicação do ano de 1985, FERRARI narra o contexto que deu origem à lei daquele estado. 
"...Em maio de 1982 a imprensa gaúcha noticiava que as águas do Rio Guaíba estavam contaminadas por resíduos de Heptacloro e Endosulfan, dois produtos da família dos organoclorados usados como inseticidas nas culturas extensivas.... Com o objetivo de traçar uma linha de ação face à ameaça que representava a contaminação das águas que abastecem a cidade, várias entidades representativas da população estabeleceram como fórum a Comissão de Direitos Humanos, órgão da Assembléia Legislativa do Estado, onde passaram a reunir-se periodicamente. O movimento decidiu adotar, inicialmente, duas providências: a)reivindicar do Governo do Estado a proibição da comercialização e uso, no território estadual, dos compostos organoclorados....b)solicitar à Secretaria da Saúde e Meio Ambiente a realização de estudos sobre a problemática dos efeitos toxicológicos..." (FERRARI, 1985:52-53).

A primeira resposta obtida pelo movimento foi a aprovação do decreto que proibiu "em todo o território do Estado a utilização de defensivos agrícolas organoclorados" (Decreto 30.787/82).

O conteúdo do decreto aprovado não atendeu aos anseios do movimento, tendo em vista que o fato de que, ao proibir a utilização e não a fabricação, ficava claro que o poder público atribuía o problema ao âmbito do agricultor, o usuário final do insumo. Para as entidades participantes do movimento uma proibição efetiva deveria atingir também o comércio e a fabricação dos produtos. É então neste contexto que se retoma a idéia do receituário agronômico que já vinha sendo praticada em algumas regiões do estado e contava com o apoio da categoria dos engenheiros agrônomos.

O grau de aglutinação conquistado pelo movimento pode ser avaliado pela análise das entidades que participaram do fórum instalado na Assembléia Legislativa do Estado, para discutir e estudar propostas aos problemas decorrentes do uso indiscriminado de agrotóxicos. Participaram do fórum a Associação Democrática Feminina Gaúcha, o Centro de Estudos de Toxicologia do RS, a Associação Gaúcha de Proteção ao Ambiente Natural (AGAPAN), a Federação das Associações de Bairros do RS, o Movimento de Justiça e Direitos Humanos, a Sociedade de Agronomia, a Sociedade de Engenharia, o Instituto de Direito Ecológico, a Fundação Balduíno 
Rambo, a Associação dos Farmacêuticos Químicos, a Associação Gaúcha de Sociólogos, o Centro dos Professores do RS, a Associação de Preservação da Natureza do Vale Gravataí, o Instituto dos Arquitetos do Brasil e o Sindicato dos Arquitetos.

As conquistas desse grupo não se limitaram aos decretos e portarias. A Lei Estadual n ${ }^{0} 7.747$, aprovada em dezembro de 1982, também foi resultante do poder de pressão agregado ao fórum que se reunia periodicamente na Assembléia Legislativa do Estado.

Vários foram os avanços contemplados na proposta de lei apresentada pelo citado fórum, em relação ao cenário de regulamentação, incipiente até então, a saber:

1) proibição de vendas, no estado do Rio Grande do Sul, de produtos importados proibidos em seus países de origem;

2) cadastramento dos comerciantes e distribuidores;

3) direito de impugnação do cadastro por entidades associativas, legalmente constituídas;

4) ampliação do instrumento do receituário agronômico para outros produtos biocidas, tais como os de uso veterinário;

5) o receituário agronômico somente seria válido se expedido por técnicos não vinculados às empresas de produção, manipulação e comércio de agrotóxicos; e

6) possibilidade de realização de análises de resíduos solicitadas pelas Comissões Técnicas da Assembléia Legislativa, visando esclarecer denúncias de contaminações ambientais.

Mas ao seguir para sanção do governador do estado, após aprovação pela Assembléia Legislativa, o projeto da lei dos agrotóxicos do Rio Grande do Sul sofreu uma série de vetos, alterando artigos importantes, descaracterizando em parte os avanços antes conquistados no âmbito do legislativo. 
Os vetos eliminavam da lei estadual os dispositivos relacionados a: a) proibição de venda de produtos importados proibidos em seus países de origem; b) possibilidade de impugnação do cadastro de agrotóxicos, por parte de entidades associativas; e c)possibilidade de realização de análises de resíduos, em laboratórios oficiais, requisitadas pelo poder legislativo.

Os vetos impostos pelo executivo não foram sustentados na Assembléia Legislativa, e dessa forma, em 14 de abril de 1983, a lei estadual de agrotóxicos do Rio Grande do Sul foi aprovada, mantendo as características originais de seus propositores.

O sentido político do movimento e da lei dos agrotóxicos é apontado por FERRARI (1985) ao afirmar que "a Lei dos agrotóxicos representou, antes de mais nada, a consolidação e a ampliação dos espaços democráticos da sociedade. Surgiu num momento em que o país ainda passava por uma situação política em que prevaleciam inúmeros mecanismos de restrição à liberdade...A elaboração da Lei dos Agrotóxicos ocorre nesse contexto, por um coletivo de representantes da sociedade civil, tendo sido uma das mais ricas experiências democráticas no que se refere à prática legislativa". (FERRARI, 1985:58)

A reação dos representantes da indústria de agrotóxicos aos movimentos bem sucedidos dos ambientalistas no Rio Grande do Sul concretizou-se pela iniciativa da ANDEF que ingressa com uma representação de inconstitucionalidade da lei estadual dos Agrotóxicos, junto ao Supremo Tribunal Federal. A argumentação principal formulada pela ANDEF sustentava que os estados não possuíam competência para legislar sobre matérias já tratadas na legislação federal.

A representação da indústria química também invocou a inconstitucionalidade da proibição do uso de organoclorados e da exigência do receituário agronômico. Os argumentos aqui se baseavam na idéia que tais medidas teriam sido, conforme observa FERRARI, "gratuitas e inspiradas em campanha emocional". Tal argumentação desconsiderava totalmente as razões e a história do movimento ambientalista iniciado 
pela contaminação apurada nas águas do Rio Guaíba, e ainda as crescentes denúncias de intoxicações envolvendo trabalhadores rurais no interior do estado.

FERRARI (1985), resumia assim as motivações da ANDEF para o desencadeamento das ações na justiça contra a lei estadual dos agrotóxicos, numa época em que ainda não se contava com uma Lei Federal para tratar o assunto:

"...Em resumo, as objeções levantadas pela ANDEF quanto à constitucionalidade da Lei dos Agrotóxicos, tiveram o claro propósito de evitar os prejuízos que as empresas acumulariam com a vigência do sistema de controle do comércio e uso dos agrotóxicos. Até mesmo porque, a nível federal, não existe qualquer restrição que represente uma ameaça aos seus interesses" (FERRARI, 1985:63).

Em agosto de 1984 o Supremo Tribunal Federal declarou parcialmente constitucional a Lei Estadual de Agrotóxicos do Rio Grande do Sul. Apesar de proporcionar a supressão de alguns pontos importantes da lei original, a sentença do STF acabou por reconhecer a competência dos Estados para legislar supletivamente sobre agrotóxicos, fato este que, sem dúvida, resultou em grande avanço para a instituição de legislações ambientais mais rígidas em outros estados da união.

Mas a luta pela regulamentação dos agrotóxicos e implantação do receituário agronômico não se restringiu ao âmbito estadual. Os esforços dos propositores da idéia do receituário agronômico também foram levados a efeito na esfera federal.

Também como produto do trabalho da Sociedade de Agronomia do Rio Grande do Sul, nasceu o projeto de Lei $n^{\circ} 148 / 79$, apresentado à Câmara Federal pelo Deputado Augusto Trein, dispondo sobre a comercialização de agrotóxicos destinados à agropecuária e instituindo a obrigatoriedade do receituário agronômico e veterinário para sua aquisição.

Esta iniciativa também sofreu forte resistência em sua trajetória, conforme registrado em reportagem da revista "Dirigente Rural", de fevereiro de 1981: 
"...Mas é preciso registrar que a concórdia não tem sido a marca mais notável da trajetória da proposta do receituário pelo Poder Legislativo. Assim, ao passar pela Comissão de Agricultura e Política da Câmara dos Deputados, o projeto inicial de Trein cedeu lugar a um substitutivo, de autoria do relator, deputado Victor Fontana, de Santa Catarina, que foi aprovado" (Dirigente Rural, janeiro/fevereiro, 1981:14).

A avaliação feita pelos envolvidos na campanha de adoção do receituário agronômico, a respeito do projeto que tramitava na Câmara Federal, não era a mais elogiável. Um dos pontos indicativos do distanciamento do projeto em relação à proposta inicial residia no fato de que o substitutivo trazia de volta a figura do "projeto fitossanitário" como forma opcional ao receituário agronômico; o que, na opinião dos agrônomos envolvidos no movimento, modificava o sentido original da proposta, conforme apontava a reportagem citada.

"...Uma das objeções mais importantes é a inclusão do chamado projeto técnico como forma opcional, o que, segundo os agrônomos envolvidos no movimento, desvirtua o sentido original da instituição do receituário, ou seja, o de um instrumento com finalidade corretiva, utilizado pelo técnico, uma vez por ele definido o procedimento fitossanitário a adotar em cada caso concreto. Nesse sentido, o receituário impede a compra antecipada ... ao introduzir o projeto técnico fitossanitário, possibilita antecipar o comércio de pesticidas, regulamentando em lei o uso indevido e os atuais erros, confunde fitossanitarismo com agroquímica" (Dirigente Rural, janeiro/fevereiro, 1981:16-17).

Mesmo considerando as modificações que se incorporavam ao texto original do projeto discutido na Câmara Federal, tal desvio não alterava as expectativas sobre os eventuais benefícios decorrentes da aprovação de uma lei federal, animavam os envolvidos na campanha de expansão da idéia para todo o país.

"...Um balanço provisório da luta em favor do receituário mostra que se fizeram grandes avanços e a aprovação de lei pelo Congresso Nacional conferirá maior força ao instrumento. De outro lado, as partes envolvidas não deixam de reconhecer a 
existência de sérias dificuldades na real implantação do receituário em todo o país, dadas as flagrantes disparidades regionais" (Dirigente Rural, janeiro/fevereiro, 1981:17).

A resposta do movimento a favor do receituário agronômico, em relação ao projeto que tramitava no Congresso Nacional, concretizou-se pelo desencadeamento de novas reuniões na Sociedade de Agronomia do Rio Grande do Sul, com a participação de representantes de vinte entidades envolvidas na questão, incluindo a Federação das Associações de Engenheiros Agrônomos do Brasil (FAEAB). A partir de tais reuniões foi concebida uma proposta para o projeto de lei do receituário agronômico, encaminhada para o Congresso, através da ação da FAEAB.

A proposta defendida pela FAEAB contemplava aspectos que visavam atender aos anseios contidos no projeto de lei original. Alguns dos pontos abordados foram:

- a definição do termo "defensivos agrícolas" incluía os produtos de uso veterinário;

- os agrotóxicos somente poderiam ser entregues ao consumo, para toda e qualquer forma de aplicação, mediante receituário fornecido por engenheiro agrônomo, engenheiro florestal ou médico veterinário devidamente habilitado;

- o receituário agronômico deveria seguir os seguintes procedimentos:

o indicar as formas possíveis de controle integrado para a situação específica (controle natural, biológico, genético, cultural, mecânico, físico, e outros);

○ indicar a descrição das lavouras a serem protegidas e suas áreas respectivas, e as possibilidades humanas e materiais para uma boa prática agrícola na aplicação de defensivos;

o indicar, no caso de aplicação de defensivos, os momentos de aplicação, equipamento a ser utilizado, o prazo de carência , a fitotoxicidade à cultura a ser protegida e às outras próximas, a toxicidade da formulação prescrita, a proteção aos aplicadores e

\footnotetext{
${ }^{\text {i }}$ Prazo de carência = intervalo (em dias ) entre a última aplicação e a colheita
} 
demais pessoas envolvidas na operação, a proteção às culturas próximas, e o destino a ser dado para as embalagens vazias;

- cada receituário deveria ser elaborado após a visita à propriedade agrícola respectiva

A proposta de implantação do receituário agronômico também sofria críticas dos ambientalistas que lutavam pela restrição e banimento dos agrotóxicos. O argumento, neste caso, baseava-se na idéia de que o receituário agronômico poderia servir para um incremento no uso de agrotóxicos, e não propriamente para sua redução.

Mas a proposta de lei federal defendida pela FAEAB apresentava uma concepção de receituário agronômico que não se restringia ao controle químico como possibilidade de prescrição e incorporava outras opções de técnicas de controle fitossanitário, conforme se pode observar em depoimento do então dirigente da FAEAB, engenheiro agrônomo Walter Lazzarini, em reportagem da revista "Raízes", em maio de 1981.

"...E, ao contrário do que alguns pensam, o receituário não será uma forma de consolidar o uso de defensivos agrícolas. Será um meio de coibi-lo. Pois o combate às pragas poderá ser feito por processo natural ou químico, conforme a receita" (Revista Raízes, maio, 1981:9).

A rigor, a luta desenvolvida pela $\mathrm{FAEAB}$, a favor da implantação do receituário agronômico, tinha um alcance maior do que a simples adoção de um sistema de controle de vendas por receita. A situação de gravidade imposta pelo uso indiscriminado de agrotóxicos em todo o país exigia um esforço dirigido a várias vertentes do problema: desde a ausência de informações toxicológicas sobre os produtos utilizados no país, até a questão da falta de incentivos às atividades de pesquisa sobre novas formas de controle de pragas e doenças na agricultura. $\mathrm{O}$ depoimento de Walter Lazzarini na citada reportagem ilustra bem esta dimensão da campanha a favor do receituário agronômico . 
"...os agrônomos vêm se mostrando numa posição crítica quanto à política agrícola atual. Estão se batendo contra o uso abusivo dos defensivos e contra a dependência da agricultura ao poder industrial. Mas não estão sendo ouvidos..."

Para Lazzarini tal situação ocorria por dois fatores:

.. a falta de um real estado de direito que permita a manifestação popular e atenda mais amplamente às suas reivindicações, concedendo o verdadeiro acesso à obtenção de informações de interesse do povo...E, de outra parte, ...ao próprio poder das multinacionais exercido no Brasil. E também a uma certa submissão oficial ao poder dessas empresas. Pois, do contrário, como justificar a inviabilização à abertura às informações que podem favorecer, inclusive, as condições para que o agrônomo prescreva mais corretamente suas receitas?" (Revista Raízes, maio, 1981:9).

O jogo de interesses envolvidos na aprovação de uma lei federal para regulamentar a questão dos agrotóxicos no Brasil fizeram com que o processo de discussão da matéria no Congresso Nacional viesse a atravessar uma série de obstáculos, a começar pelo número de propostas adicionais que surgiam pelas mãos de vários deputados.

Assim, no ano de 1981, além da proposta original apresentada pelo deputado gaúcho Augusto Trein, tramitavam pelo menos outras três propostas: o projeto de lei $\mathrm{n}^{\mathrm{o}}$ 1968/79 do deputado Délio dos Santos, o projeto de lei nº1582/79, de autoria do deputado Júlio Campos, e ainda um quarto projeto nº82 apresentado em 1979 pelo deputado Freitas Nobre. Por fim todas estas propostas deram lugar ao projeto substitutivo elaborado pelo deputado Victor Fontana, de Santa Catarina.

As reações desencadeadas contra o projeto substitutivo agregaram mais complexidade às discussões no Congresso Nacional, de tal forma que no período entre 1981 e 1985 poucos avanços foram possíveis neste âmbito. 
Já as discussões na esfera estadual tomavam proporções importantes e resultavam em proposições e dispositivos de lei que buscavam dar conta do problema no âmbito estadual.

Em meados de 1984 os quatro principais estados consumidores de agrotóxicos, responsáveis por cerca de $80 \%$ da demanda, já haviam aprovado suas respectivas leis (São Paulo, Paraná, Rio Grande do Sul e Mato Grosso do Sul) e as reações da indústria alimentavam o debate.

"...Pressionada por diferentes exigências em quatro Estados, incluindo registro, cadastro, rotulagem, receituário agronômico, explicações sobre dosagens, períodos de carência e outros detalhes, a indústria de defensivos agricolas diz estar num impasse. E está apelando ao Ministério da Agricultura para que interfira na questão, visando chegar a uma legislação harmoniosa, que possa ser cumprida pelas empresas em todo o território nacional. Mas, segundo a ANDEF, o Ministério continua inexplicavelmente omisso" (Dirigente Rural, março, 1984:31).

Entre 1982 e 1985 cerca de 15 estados e alguns municípios gaúchos já contavam com leis aprovadas, regulando o comércio e o uso dos agrotóxicos (GUERRA \& SAMPAIO, 1991:24).

Esse processo de elaboração das leis estaduais também foi acompanhado de um amplo debate, associado a uma guerra judicial desencadeada por reação dos representantes das empresas de agrotóxicos, contrários à regulamentação nos níveis propostos. O principal argumento das indústrias contra o processo de regulamentação estadual relacionava-se ao grau de dificuldade imposto pela situação de atendimento de diferentes requisitos desenhados em cada estado, como fruto das leis estaduais. A reação maior dizia respeito à lei aprovada no Rio Grande do Sul, onde as imposições da lei eram mais rígidas.

A rigor a indústria não se declarava claramente contra o processo de regulamentação nos estados, desde que a lei guardasse uniformidade e compatibilidade 
com a legislação de nível federal. Mas o argumento apresentado não esclarecia que a lei federal até então em vigor era totalmente defasada, pois ainda era regida pelo Decreto Federal no 24.114, de 12 de abril de 1934, que aprovou o chamado "Regulamento de Defesa Sanitária"; legislação esta concebida antes mesmo de serem feitas as descobertas a respeito das propriedades inseticidas do DDT.

Então, ao propor a "harmonização" das leis estaduais com a legislação federal, os representantes da indústria de agrotóxicos impunham um parâmetro incompatível para a elaboração de mecanismos que viessem a dar conta dos problemas detectados pelo uso indiscriminado de agrotóxicos no Brasil.

Alguns dos principais pontos que atingiam os interesses da indústria de agrotóxicos, a partir da aprovação das leis estaduais, foram apontados em reportagem da revista "Dirigente Rural", do ano de 1984:

"...São numerosos os pontos das legislações estaduais sobre defensivos agrícolas que atingem a indústria. Mas um dos mais repudiados pelas empresas estabelece, no Rio Grande do Sul, a especificação do processo físico ou nome do agente biológico" (Dirigente Rural, março, 1984:31).

A reação da indústria em relação a este ponto é incisiva, nas palavras de Lourenço Vieira da Silva, então presidente da ANDEF:

"...tratando-se de um produto químico, que não tem agente biológico, a especificação do processo físico é a revelação do próprio segredo industrial. Seria então o caso de obter-se, por lei, o que a espionagem industrial tem como seu principal objetivo" (Dirigente Rural, março, 1984:31).

Este nível de argumentos em defesa da preservação das informações técnicas sobre os agrotóxicos, por conta dos interesses comerciais, mostrava de certa forma o grau de sensibilidade frente aos graves problemas de ordem toxicológica e ambiental, amplamente detectados à época por parcelas da sociedade organizada; problemas estes 
cujas soluções não poderia prescindir do conhecimento sobre as características e o comportamento das moléculas que compunham os agrotóxicos.

Da mesma forma, a questão da efetividade da proposta do receituário agronômico trazia consigo a necessidade básica de conhecimentos sobre os produtos aprovados para uso no país, além de detalhes sobre suas características e modos de ação. Neste contexto havia coerência na exigência de cadastro, reavaliação, classificação toxicológica e divulgação das informações sobre os produtos, etapas estas contempladas em quase todas as legislações estaduais que passavam a ser aprovadas, e que recebia a forte reação contrária das indústrias.

A estratégia dos representantes das indústrias de agrotóxicos para fazer frente ao movimento crescente de regulamentação nos diversos estados que construíam suas legislações, foi a de pressionar, promover e apoiar as iniciativas do governo na proposição de uma lei federal sobre a matéria.

Assim, as discussões que haviam iniciadas no Congresso Nacional, ao início dos anos 80, a partir do projeto original de Augusto Trein, foram retomadas. A situação deste debate, até então, não havia avançado muito pois, a partir da apresentação e das reações ao projeto substitutivo de autoria de Victor Fontana, o assunto não estava contemplado como prioridade na agenda do Congresso Nacional.

Mas, na retomada estratégica do debate sobre uma lei federal para contrapor aos avanços dos estados, novamente o governo encaminha proposta de lei para discussão do tema no Congresso Nacional, conforme ilustra a reportagem da "Folha de São Paulo", de junho de 1984:

"...A nova legislação federal que regulamentará o uso de agrotóxicos no País deverá institucionalizar o receituário agronômico e criar um conselho interministerial para a importação de produtos químicos destinados à fabricação de defensivos agricolas(...) 
(...)Amanhã uma advogada gaúcha, especialmente contratada pelo ministro da Agricultura, Nestor Jost, deverá supervisionar o projeto de lei.

Sabe-se, entretanto, que os principais itens do projeto são a institucionalização do receituário agronômico (embora de uma forma bem menos ampla do que a contida na legislação do Rio Grande do Sul, por exemplo)...." (Folha de São Paulo, 26 de junho, 1984).

A proposta de lei do governo federal era elaborada através do trabalho de uma comissão interministerial que atuava sem interlocução com a sociedade. Estas eram as maiores críticas que a proposta sofria: as ausências de transparência e de participação democrática nos debates.

"... O texto do projeto de lei dos agrotóxicos do governo federal, que deverá ser enviado ao Congresso no começo de agosto, tem sido mantido em sigilo. Mas ontem, o deputado estadual Walter Lazzarini (PMDB) divulgou a $1^{a}$ versão final do anteprojeto...e divulgou nota à imprensa qualificando o projeto de uma ação espúria e mais um engodo com que se tentará envolver o Parlamento Nacional e a própria sociedade brasileira (...)

(...)Para o deputado e engenheiro agrônomo, a legislação dos agrotóxicos que o governo federal está propondo tem como objetivo principal centralizar todo o poder de decisões sobre o assunto em um único órgão a ser criado, o CNDAA - Conselho Nacional de Defensivos Agrícolas e Afins" (Folha de São Paulo, 30 de junho,1984).

A argumentação dos defensores do movimento pela restrição aos agrotóxicos buscava também agregar ao debate público da questão, aspectos que pudessem dar visibilidade do grau de intimidade existente entre as figuras políticas e autoridades do governo federal e a indústria química, conforme se pode constatar na reportagem da "Folha de São Paulo", à época. 
"...Walter Lazzarini considera grave atribuir a 15 membros do Conselho o poder de decisão. Toda sorte de pressões será possível sobre esse Conselho - diz o deputado em sua nota, acrescentando:As multinacionais dos agrotóxicos sabem onde recrutar seus altos funcionários, e podem remunera-los bem. O general Golbery do Couto e Silva foi presidente da Dow Chemical. O atual ministro da Agricultura, sr. Nestor Jost, em 30 de abril de 1976 entrou para o Conselho de Administração da Bayer, juntamente com o general Idálio Sardemberg e com o sr. Octávio Gouveia de Bulhões. Em 29 de abril de 1977 o sr. Jost foi nomeado presidente do Conselho de Administração da Bayer" (Folha de São Paulo, 30 de junho, 1984).

A preocupação com a proposta de lei federal, quanto ao Conselho a ser instituído, residia exatamente na pouca credibilidade sobre a possibilidade de uma ação governamental livre das pressões e dos comprometimentos com a indústria dos agrotóxicos.

Em relação ao receituário agronômico a proposta do governo federal contemplava, em um de seus parágrafos, sua implantação, mas praticamente o anulava nos parágrafos seguintes, na medida em que não estabelecia os critérios em que o uso do receituário agronômico seria necessário.

As críticas em relação ao padrão centralizador da proposta de lei federal enviada ao Congresso surgiam também dentro de parcelas dos próprios quadros governamentais, sintonizados com a questão ambiental. Um exemplo disto pode ser observado no depoimento prestado ao jornal "Folha de São Paulo", pelo então secretário especial do Meio Ambiente, Paulo Nogueira Neto:

"...o que precisa ser aperfeiçoado no projeto é a participação do Estado. Nós estamos desenvolvendo uma política de descentralização e cabe aos Estados terem sua legislação específica a ser aplicada em casos peculiares. Querer resolver o problema dos Estados em Brasília não dá certo" (Folha de São Paulo, 31 de julho, 1984). 
Entretanto o pensamento dos representantes das indústrias de agrotóxicos seguia em sentido exatamente oposto. Na visão destes a existência de uma legislação única a nortear os procedimentos agregava mais racionalidade no estabelecimento das regras a serem impostas na questão dos agrotóxicos. Além disso, a visão inicialmente contrária da indústria em relação ao receituário agronômico, começa a ser modificada, na medida em que a existência deste instrumento (agora caracterizado como mero controle de vendas) poderia servir como um anteparo na divisão das responsabilidades em torno do uso indiscriminado dos agrotóxicos e suas decorrências, que até então recaiam basicamente sobre as empresas fabricantes dos produtos.

Esta posição pode ser verificada pelos depoimentos do representante da ANDEF à reportagem do jornal "Folha de São Paulo", à época:

"...Mas não há unanimidade na necessidade de participação estadual na questão dos agrotóxicos. O presidente da Associação Nacional dos Defensivos Agrícolas acredita que finalmente o País terá uma legislação única. A ANDEF vem tentando revogar, junto ao Supremo Tribunal Federal, as legislações estaduais de agrotóxicos, e este projeto que estamos analisando com cuidado deve regular os procedimentos de forma geral. Ele ainda cita alguns itens como sendo positivos: a centralização de poder aos ministérios da Saúde, Trabalho, Interior, Agricultura e Indústria e Comércio, a discussão sobre produtos a serem comercializados no Brasil, a criação de um receituário, o direito de prescrever o uso de defensivos e a divisão de responsabilidades. Antes, toda a culpa recaía sobre a indústria" (Folha de São Paulo, 31 de julho, 1984).

Outro indicativo da mudança de posição da indústria em relação ao receituário agronômico pode ser verificado nos argumentos apresentados em artigo intitulado "Mais bom senso e menos emoção" publicado no boletim de divulgação "DEFESA VEGETAL", produzido pela ANDEF:

"...A questão deixou definitivamente de ser técnica e tornou-se política. Existem muitas pessoas falando sem conhecimento do assunto. As indústrias não são 
contrárias a restrições a nenhum produto, mas insistem em que estas restrições tenham respaldo técnico-cientifico, assim como desejam que as alternativas propostas sejam viáveis em termos de custo-beneficio" (Defesa Vegetal, novembro/dezembro, 1984:3).

$\mathrm{Na}$ medida em que as discussões sobre a questão dos agrotóxicos seguiam basicamente focalizadas nos aspectos legais e nas batalhas jurídicas em torno das legislações estaduais e dos projetos de lei federal, a abordagem do tema receituário agronômico acabava limitada aos aspectos burocráticos do instrumento.

A limitação das discussões aos seus aspectos burocráticos distanciava a proposta de receituário agronômico de seus preceitos originais, especialmente nos aspectos propostos por um de seus principais precursores, o prof. Guerra, da Universidade Federal de Pelotas. Assim, o termo "receituário agronômico" vai perdendo seu caráter enquanto denominação para a atividade e doutrina técnica a ser exercitada no manejo dos problemas de pragas e doenças nas atividades agropecuárias, e começa a ganhar o sentido de "instrumento de controle das vendas de agrotóxicos", e neste contexto vai tornando-se sinônimo de "receita", termo este utilizado na maioria dos textos legais.

Esta dimensão burocrática do receituário agronômico é alimentada pelos representantes da indústria dos agrotóxicos, os quais passam a ver neste instrumento a possibilidade de "dividir as responsabilidades" sobre os problemas relacionados ao uso dos agrotóxicos.

"...O projeto de lei do Governo Federal que tramita no Congresso define responsabilidades nos vários segmentos que manipulam defensivos de alguma forma e esse é um aspecto novo e muito importante. O projeto estabelece responsabilidades ao nível da indústria, que deve responder pelas especificações que o Governo fixa; ao nível do revendedor, que só poderá vender o produto com receituário; ao nível do engenheiro agrônomo, que deverá respeitar as especificações do fabricante; e ao nível do usuário, que deverá fazer o uso adequado do defensivo" (Defesa Vegetal, novembro/dezembro, 1984:3). 
A proposta de lei federal apresentada pelo governo ao Congresso Nacional em outubro de 1984 sofreu fortes críticas, cujas repercussões levaram o governo a retirar o projeto um mês depois. Ao final de novembro do mesmo ano o projeto foi reapresentado, agora sem o caráter de urgência, levando a discussão da matéria para o segundo plano na agenda do Congresso (Dirigente Rural, dezembro, 1984:21).

Entre os anos de 1984 e 1989 os processos de regulamentação dos agrotóxicos ficaram restritos aos esforços de aprovação e implementação das legislações estaduais. As discussões e tentativas de implantação do receituário agronômico nos estados tomavam rumos diferenciados e, na maioria da vezes, seguiam distanciando-se dos preceitos originais da proposta.

Em entrevista concedida no ano de 1985, ao jornal "O Estado de Santa Catarina", sob o título de "Receituário Agronômico corre risco de ser descaracterizado", um dos propositores da idéia do receituário agronômico, prof. Guerra, da Universidade Federal de Pelotas, demonstra toda a preocupação com as distorções nas discussões em torno do instrumento:

"...Após a experiência do Rio Grande do Sul o primeiro Estado a ser atingido pelo RA foi Santa Catarina...Depois fizemos vários cursos no Paraná e praticamente fomos levando o Receituário para todos os Estados, restando apenas alguns do Nordeste. É claro que uma nova idéia, uma nova metodologia não pode ser assimilada de uma hora para outra. É preciso trabalho, sobretudo lento, de conscientização que envolve ética profissional e muita capacitação. É um processo que demanda tempo(...)

(...)A comunidade está totalmente aberta à idéia, está exigindo o RA e se ele não está andando melhor é por falta de uma melhor fiscalização do Governo. Lamentavelmente a falta de fiscalização por parte da Defesa Sanitária Vegetal vem permitindo que algumas coisas erradas possam acontecer como essas receitas dadas em branco" (O Estado de Santa Catarina, 31 de maio, 1985). 
Indagado sobre o grau de preparo e a receptividade dos agricultores em relação ao receituário agronômico, o prof. Guerra mostrava-se cético sobre as possibilidades de superar-se as campanhas contrárias ao instrumento, deflagradas pelos grupos interessados na venda livre dos agrotóxicos.

"Embora tenham sido feitos muitos contatos através das cooperativas, muito tem que ser feito no sentido de conscientizar o agricultor, que tem sido muito influenciado por grupos interessados na venda de defensivos agrícolas, numa campanha tentando descaracterizar e prejudicar a instituição do Receituário Agronômico e eles estão muito em contato com o agricultor. Eu acho que o outro lado, o lado interessado em promover o Receituário, não está conseguindo dar aquele tipo de informação que o agricultor precisa, ou seja, no sentido de mostrar as vantagens que ele tem através do $R A$, de usar um produto realmente adequado, na hora certa, evitando aplicar produtos extremamente caros e desnecessários à lavoura" (O Estado de Santa Catarina, 31 de maio, 1985).

De fato, as experiências até então bem sucedidas em relação ao receituário agronômico mostravam claramente a necessidade de envolvimento concreto dos serviços de extensão, e da fiscalização dos serviços de defesa agropecuáira, a exemplo do ocorrido no estado do Rio Grande do Sul.

Naquele estado, após a aprovação da lei de agrotóxicos, em 1982, vários esforços foram desencadeados no sentido da implementação efetiva do instrumento. Além dos aspectos de divulgação junto aos agricultores e de capacitação do corpo técnico de agrônomos (oficiais e privados), várias medidas foram tomadas no campo institucional para viabilizar um sistema de acompanhamento e fiscalização da atividade do receituário agronômico, conforme assinalava Guerra, na citada entrevista ao jornal catarinense.

"No Rio Grande do Sul, a fiscalização está estruturada através da Secretaria da Saúde e da Secretaria da Agricultura, com apoio na Lei de Agrotóxicos. Cabe à Secretaria da Agricultura a fiscalização da aplicação dos agrotóxicos e à Secretaria 
da Saúde a fiscalização à comercialização dos produtos agrotóxicos. A Saúde vem trabalhando em conjunto com o CREA, de modo que a fiscalização se faz simultaneamente com técnicos da Saúde e do CREA, que contratou inclusive um corpo de agrônomos só para cuidar da fiscalização do Receiutário junto às casas comerciais e isto está colocando o pessoal dentro das normas" (O Estado de Santa Catarina, 31 de maio, 1985).

O envolvimento dos serviços de extensão rural na implantação e prática do receituário agronômico no estado do Rio Grande do Sul foi fundamental para o sucesso da iniciativa. A determinação da diretoria técnica da Empresa de Assistência Técnica e Extensão Rural (EMATER), na implementação do receituário agronômico no estado, deu origem a um grupo de trabalho, específico para estabelecer e supervisionar a sistemática de funcionamento do receituário agronômico no serviço de extensão.

Um exemplo desse compromisso da EMATER-RS com a implantação do receituário agronômico pode ser verificado ao analisar-se o texto da carta circular da Coordenação de Operações, dirigida aos gerentes regionais dos escritórios da EMATER o estado. Neste texto várias instruções e orientações são fornecidas pelo órgão de coordenação, dentre as quais podemos destacar:

"Todos os Escritóros deverão dar, necessariamente, prosseguimento à divulgação sobre a matéria pretinente a defensivos, contida na legislação em vigor, salientando as responsabilidades que envolvem o seu comércio e uso, e os aspectos mais importantes relacionados com a educação do produtor (...)

(...)Convém enfatizar, ainda, que todos os Escritórios dêem continuidade aos programas de controle integrado, buscando maior ordenamento e racionalidade no uso de defensivos, como aliás, tem sido constantemente recomendado através de diversos expedientes internos(...)" (EMATER-RS, Circular nº COPER/38-83). 
Os cuidados em relação aos procedimentos metodológicos para a prática do receituário agronômico faziam com que todos os detalhes fossem previamente estabelecidos pela coordenação dos serviços de extensão, inclusive com o estabelecimento de critérios bem definidos sobre a necessidade de visitas às propriedades, antes do trabalho de prescrição técnica, conforme mostra o documento da EMATER-RS:

"Julgamos que a visita à propriedade será sempre recomendável, entretanto, sendo grande a demanda prevista com o fim de aquisição de defensivos, nem sempre será possível realizá-la no momento oportuno (...).

\section{(...) Casos em que a visita poderá ser dispensada:}

1. quando se tratar de defensivos enquadrados nas classes III e IV...

2. quando se tratar de produtor assistido, sendo já conhecido seu estabelecimento e, também, se conheça o agente etiológico ou problema que esteja afetando a produção;

3. quando o trabalho for realizado por grupo de produtore assistidos...

4. quando se tratar da aplicação de formicidas em geral (classes III ou IV) (...)

(...) Observação: Em todos os casos, a condição de dispensa prévia da visita à propriedade ficará respaldada pela plena segurança de que o produtor foi suficientemente esclarecido sobre o correto uso do defensivo, medidas de prevenção de acidentes e demais recomendações importantes formalizadas no receituário agronômico.

Casos em que a visita não poderá ser dispensada:

1. quando se tratar de defensivos enquadrados nas classes toxicológicas I e II...

2. quando se tratar da aplicação de defensivos pela aviação agrícola...

3. quando se tratar de produtores que, costumeiramente, fazem a aplicação de defensivos contrariando as recomendações técnicas...

4. quando a aplicação é feita, costumeiramente, por empregados, sem a presença do produtor; 
5. quando se tratar de aplicação de defensivos em lavouras localizadas perto de povoações, escolas, arroios ou fontes d'água de uso comum(...)" (EMATERRS, Circular n ${ }^{\circ}$ COPER/38-83).

O contexto de trabalho dos serviços de extensão rural no Estado do Rio Grande do Sul estava presente em 195 dos 244 municípios gaúchos, significando que "80\% dos municípios contavam com a assistência da EMATER." (SECCHI, 1986:3).

As equipes de extensão reuniam no total cerca de 1.112 técnicos, sendo que dentre estes, 248 engenheiros agrônomos atuavam na execução dos programas, incluindo a participação na prática do receituário agronômico.

Mas este não era o quadro geral nas outras regiões do país onde se tentava a implantação do receituário agronômico.

No Estado de São Paulo, por exemplo, a situação de implantação e operação do receituário agronômico passou por vários momentos e iniciativas, porém sem o respaldo institucional de longo prazo necessário para seu funcionamento, inclusive em relação ao aspecto legal.

A legislação regulamentando os agrotóxicos no estado de São Paulo, e instituindo o receituário agronômico (Lei $n^{\circ} 4.002$ ), foi apresentada na Assembléia Legislativa do Estado, pelo então deputado Walter Lazzarini, e teve sua aprovação em ao final do ano de 1983, mas somente foi sancionada em janeiro de 1984.

O sistema concebido pela legislação em São Paulo estabelecia que os produtos agrotóxicos e outros biocidas somente poderiam ser entregues ao consumo mediante prescrição por engenheiro agrônomo, engenheiro florestal, médico veterinário ou zootecnista, dentro de suas atribuições, através do receituário agronômico.

Os produtos especificados como pertencentes à classe toxicológica IV estavam excluídos da obrigatoriedade. 
A lei fazia ainda uma menção específica sobre a necessidade de que cada receita fosse emitida "após visita do profissional habilitado à propriedade agrícola" (parágrafo $3^{\circ}$, do artigo $7^{\circ}$, da Lei $n^{\circ} 4.002 / 84$ ).

Outro dispositivo importante na lógica de implantação do receituário agronômico preconizada pela legislação dizia respeito às recomendações que deveriam estar complementando o conteúdo das receitas.

"...O Receituário Agronômico deverá conter também recomendações de formas de controle integrado de pragas e doenças para a situação específica, compreendendo controle natural, biológico, genético, cultural, mecânico, físico e outros necessários, bem como as medidas de segurança e higiene do trabalho a serem adotadas" (parágrafo $4^{\circ}$, do artigo $7^{\circ}$, da Lei $n^{\circ} 4.002 / 84$ ).

A integração institucional para a implantação e operação do sistema de receituário agronômico, preconizado explicitamente na legislação paulista, também representava uma inovação em relação às outras leis estaduais, mas talvez este tenha sido um dos aspectos que tornaram ainda mais difícil o caminho de regulamentação da lei aprovada. Tal integração surgia como requisito para o cumprimento das disposições de pelo menos dois artigos da citada lei: o artigo $9^{\circ}$, relativo ao sistema de fiscalização; e o artigo $10^{\circ}$, que implantava a figura do "aplicador habilitado" para os casos de uso dos produtos das classes toxicológicas I e II.

"....Os modelos de Receituário Agronômico (...) bem como o modo pelo qual se procederá ao cadastramento dos estabelecimentos $e$ à fiscalização dos mesmos,(...)serão objeto de portaria a ser editada conjuntamente pelos Secretários de Estado de Agricultura e Abastecimento, de Obras e do Meio Ambiente e da Saúde.

(...)A aplicação dos agrotóxicos e outros biocidas incluídos nas classes toxicológicas I e II só poderá ser efetuada por aplicadores habilitados através de treinamento realizado pela Secretaria de Agricultura e Abastecimento, com a 
participação das Secretarias da Saúde e das Relações de Trabalho" (artigos $9^{\circ}$ e 10, da Lei $\left.n^{\circ} 4.002 / 84\right)$.

Antes mesmo de ser regulamentada a Lei $n^{\circ}$ 4.002/84 foi alterada em abril de 1986, através da Lei $\mathrm{n}^{0}$ 5.032. Um dos aspectos modificados dizia respeito exatamente à questão da integração interinstitucional no cumprimento dos aspectos relacionados a fiscalização e ao modelo de receituário agronômico .

Pela nova lei as atribuições antes divididas entre as Secretarias de Estado da Agricultura, Saúde e Meio Ambiente, ficaram restritas à ação da área de agricultura. Entretanto tal mudança não surtiu efeito significativo na agilização do processo de implantação e regulamentação da lei, tendo em vista que o primeiro decreto a regulamentar a matéria somente foi aprovado 3 anos depois, em outubro de 1989, através do Decreto $n^{0} 30.565 / 89$.

No período decorrido entre a aprovação da lei paulista para os agrotóxicos e sua regulamentação (entre 1984 e 1989), várias tentativas de implantação de um sistema para o receituário agronômico foram experimentadas, entretanto nenhuma delas teve sucesso efetivo na operacionalização e quase sempre a visão atribuída ao sistema de receituário agronômico guardava muito pouca relação com a doutrina inicialmente proposta, aproximando-se mais de um sistema para controle das vendas de agrotóxicos.

Um exemplo dessas tentativas no Estado de São Paulo foi a iniciativa levada a efeito pela Secretaria de Agricultura e Abastecimento, em julho de 1985, implantando uma ação institucional denominada "Programa de Racionalização do Uso de Agrotóxicos".

As justificativas apresentadas para o lançamento do programa faziam referência à necessidade de enfrentamento da questão do uso indiscriminado dos agrotóxicos, em todas as suas vertentes, incluindo os aspectos e requisitos institucionais e políticos 
envolvidos, conforme registrado nas palavras do secretário de agricultura, Nelson Mancini Nicolau, no documento de lançamento do programa.

"...Há necessidade do aprimoramento da legislação existente, tornando mais rígidos os critérios de registro dos agrotóxicos e melhorando a eficiência da fiscalização sobre seu comércio e uso.

...Aos Estados e Municípios deve ser garantido o direito de legislarem supletivamente e atuarem em conjunto com a esfera federal.

...Além do aperfeiçoamento legal, torna-se necessário obter o controle político da produção de insumos agropecuários e também toda a economia brasileira. E tal controle somente será possível quando modificarmos o modelo político e econômico instaurado no País nas últimas décadas.

...As mudanças já se prenunciam. O poder autoritário agoniza e não tardará o rompimento das teias que nos amarram a tudo aquilo que o FMI hoje representa.

...No contexto no novo Brasil que se aproxima, a agricultura terá que não somente ser reorganizada em sua estrutura, mas também reorientada do ponto de vista tecnológico.Dessa chamada moderna agricultura, baseada em tecnologia importada e mal adaptada, caminharemos para a construção de uma agricultura própria, brasileira, coerente com nossos recursos naturais e nossa condição tropical. Uma agricultura socialmente mais justa e ecologicamente mais equilibrada" (NICOLAU, 1985).

O reconhecimento da necessidade de maior agilidade na ação pública de controle dos agrotóxicos também merecia destaque nas justificativas do programa.

"Essas duas considerações, a do uso indiscriminado e a da eficácia relativa dos agrotóxicos, aliadas às crescentes pressões advindas da sociedade, levaram a Secretaria de Agricultura e Abastecimento a elaborar este programa de 
racionalização do uso de agrotóxicos, procurando reforçar sua atuação em setores onde já se desenvolvem trabalhos de suma importância para a agricultura paulista.

...Independente do resultado concreto das discussões que ora se travam acerca das legislações estaduais e federais de agrotóxicos, é urgente o aprimoramento da atuação da Secretaria de Agricultura e Abastecimento, agindo com maior competência e rigor na questão dos agrotóxicos, procurando defender os interesses dos produtores rurais, salvaguardar a saúde dos trabalhadores e zelar pela qualidade dos alimentos e do meio ambiente" (SECRETARIA DE AGRICULTURA E ABASTECIMENTO DO ESTADO DE SÃO PAULO, Programa de Racionalização do Uso de Agrotóxicos, 1985:1-2).

Dentre os objetivos gerais do programa constava "fiscalizar rigorosamente a comercialização de agrotóxicos, zelando pela qualidade dos mesmos e visando a aplicação do receituário agronômico"; e o tema do receituário agronômico mereceu ainda uma referência explícita de "ação concreta imediata", qual seja: "elaborar e dirigir novo modelo de Receituário Agronômico, de acordo com o estabelecido pela Lei Estadual 4.002/84, exigindo dos técncios da rede da CATI sua utilização gratuita em seu atendimento normal".

A iniciativa do programa foi bem recebida junto à comunidade técnica envolvida na luta contra o uso indiscriminado dos agrotóxicos, e a imprensa dedicou espaço relevante para a divulgação e discussão do assunto, em especial do mecanismo de implantação do receituário agronômico, conforme observa-se em reportagem publicada à época pelo suplemento agrícola do jornal "O Estado de São Paulo":

"...sempre que o agricultor fizer consulta aos agrônomos das casas de Agricultura e dela resultar recomendação do emprego de defensivos, independente do seu grau de toxicidade, ele receberá o receituário agronômico, que deverá ser apresentado nas casas especializadas, na hora de comprar os produtos. 
...O objetivo do receituário agronômico é reduzir o uso indiscriminado e incorreto de defensivos. Nossa proposta é educativa, diz Francisco Graziano Neto, coordenador da Assessoria Técnica da Secretaria da Agricultura, Não temos a pretensão de eliminar o emprego de defensivos, e sim induzir os agricultores a usá-los corretamente, explica" (O Estado de São Paulo, 10 de julho, 1985).

O aspecto "educativo" da iniciativa tinha também outras razões: as legislações estaduais que tornavam obrigatório o uso do receituário agronômico haviam sofrido um intenso desgaste nos debate jurídicos desencadeados pelas denúncias da ANDEF, junto ao STF; e neste contexto a aplicação generalizada dos dispositivos estava de certa forma comprometida pelos aspectos judiciais e políticos. Neste contexto a saída foi tentar buscar uma implantação "pedagógica" do receituário agronômico, o que foi feito quando se instituiu por medida "administrativa" o receituário agronômico no âmbito do serviço oficial de extensão, deixando a iniciativa privada (cooperativas, empresas comerciais, consultores privados) inicialmente fora do sistema.

A preocupação quanto à inocuidade da campanha do receituário agronômico circunscrita ao serviço de extensão pode ser observada no depoimento do presidente da Associação dos Engenheiros Agrônomos do Estado de São Paulo, Sinézio Martini, concedido na reportagem antes citada.

"O receituário é uma conquista muito importante, afirma o presidente da Associação de Engenheiros Agrônomos do Estado de São Paulo, Sinézio Martini. Porém, ele não acredita que a simples instituição do receituário agronômico nas casas da Agricultura vá resolver os problemas do mau uso de agrotóxicos, sua comercialização indiscriminada e os acidentes.

(...)De qualquer forma, ele acha indispensável a existência de uma lei que ofereça à Secretaria instrumento para fiscalizar a comercialização de defensivos e punir os responsáveis.Aí, sim, seria possível conseguir fazer com que os defensivos fossem usados de forma correta. Assim, sempre que o agricultor fosse comprar um defensivo, ele seria obrigado a dispor de um receituário, e receberia orientação do melhor uso. $E$ 
também a Secretaria teria poderes legais para coibir vendas indiscriminadas de defensivos (O Estado de São Paulo, 10 de julho, 1985).

A inocuidade da campanha de implantação "educativa" do receituário agronômico no Estado de São Paulo não era apenas percebida por parcelas da corporação agronômica envolvida na questão do uso indiscriminado dos agrotóxicos. Também os representantes da indústria de agrotóxicos demonstravam pouca preocupação quanto aos aspectos restritivos da campanha pois, ao mesmo tempo em que desencadeavam batalhas judiciais para tentar vetar as iniciativas das leis estaduais sobre a matéria, eram capazes de elogiar o programa implantado pela Secretaria de Agricultura do Estado de São Paulo.

"...O receituário é altamente positivo e tem todo nosso apoio, diz Marcus Peçanha, presidente da Associação Nacional de Defensivos Agrícolas (Andef). Somos inteiramente favoráveis à obrigatoriedade do fornecimento do receituário agronômico na compra de defensivos, explica" (O Estado de São Paulo, 10 de julho, 1985).

A idéia colocada aqui sobre o receituário agronômico reduz o instrumento a um simples passo burocrático no processo de compras de defensivos. Para os representantes da indústria de agrotóxicos a questão agora era apoiar o "fornecimento do receituário agronômico na compra de defensivos", algo bastante distante da idéia inicial concebida para o sistema, que estava embasado em doutrina metodológica de manejo de pragas e prevendo, inclusive, o estímulo para a aplicação de outras técnicas de menor impacto, visando a eliminação do uso dos agrotóxicos.

Desprovido de seu conteúdo inicial e reduzido a um instrumento de controle de vendas implantado em "fase experimental" com objetivos "educativos", o receituário agronômico proposto pela Secretaria da Agricultura de São Paulo inspirava apenas algumas preocupações da indústria, no tocante à dinâmica das vendas. Neste aspecto havia muita preocupação com os reflexos negativos potencialmente previstos nos fluxos de vendas, a partir da implantação do instrumento, conforme verificado em 
depoimento concedido ao jornal "Folha de São Paulo", por Marcos Peçanha, presidente da ANDEF:

"...O presidente da Andef...é favorável à iniciativa da secretaria paulista. Mas afirma que a indústria se preocupa com a praticabilidade do receituário. Diz que a medida, embora não seja obrigatória, pode dificultar o acesso dos produtos ao agricultor por problemas burocráticos.

(...) Nos cálculos da Andef, os mil engenheiros agrônomos da secretaria paulista não seriam suficientes para visitar as mais de 320 mil propriedades de São Paulo, para elaborar receitas, o que pode burocratizar o trabalho e emperrar as vendas(...)" (Folha de São Paulo, 7 de setembro, 1985).

Entretanto a prática veio a demonstrar que a tentativa de implantação do receituário agronômico no âmbito dos serviços de extensão no estado de São Paulo, no ano de 1985, não ofereceu grandes impactos na questão do uso indiscriminado. Dentre as dificuldades impostas à iniciativa, um problema surgiu como fator limitante da experiência: a questão da responsabilidade técnica e o relacionamento institucional entre a Secretaria da Agricultura e o Conselho Regional de Engenharia.

A controvérsia estabelecida dizia respeito aos custos advindos do processo de "anotação de responsabilidade técnica", previsto por dispositivo legal no âmbito do sistema CONFEA-CREA; custos estes com os quais o poder público (serviço oficial de extensão rural) não estava disposto a arcar.

A exemplo do ocorrido em outros estados, como no Rio Grande do Sul, ao ser implantado o receituário agronômico, identificou-se a necessidade do estabelecimento de um sistema de controle do exercício profissional intrínsico à atividade de "prescrição de receitas". Assim, pela ação dos articuladores que buscavam a implantação formal do receituário agronômico e sua legitimação enquanto atividade técnica, foi construído o envolvimento institucional dos Conselhos Profissionais na questão. Tais Conselhos, usando de suas sistemáticas, estabeleceram a obrigatoriedade 
de que cada receita emitida (ou conjunto de receitas) fosse registrada e tivesse a autoria identificada. Isto, na linguagem e nas normas e leis que apóiam a ação desses Conselhos, traduz-se pela instituição da "anotação de responsabilidade técnica" (A.R.T) e pelo recolhimento da respectiva "taxa" prevista em lei, para cobrir os custos do sistema.

Como a implantação inicial em São Paulo dava-se apenas no âmbito dos serviços públicos (Casas da Agricultura), e o fornecimento das receitas aos produtores deveria ser gratuito, a questão dos custos das A.R.T's ficou sem cobertura, gerando uma grande polêmica entre os atores governamentais e os representantes do Conselho Profissional.

Não havendo "acordo" sobre as possibilidades de "dispensa" na cobrança das taxas de anotação de responsabilidade técnica, a resultante final do problema traduziu-se pelo esvaziamento da iniciativa; ou seja: na prática os serviços de extensão deixaram de fornecer as receitas. Ficava assim frustrada mais uma iniciativa de implantação do receituário agronômico no estado de São Paulo.

Em relação aos caminhos trilhados para a operacionalização do receituário agronômico em cada um dos estados que conseguiam aprovar suas legislações locais, o quadro de dificuldades a serem vencidas era comum às diversas iniciativas. Um ponto geral de fragilidade na implantação do receituário agronômico dizia respeito às condições de capacitação do profissional de agronomia para o exercício da atividade do receituário agronômico, conforme a doutrina inicialmente proposta para o instrumento. O reconhecimento das dificuldades no âmbito da formação dos engenheiros agrônomos estava presente, inclusive, na visão dos atores responsáveis por essas atividades, nas faculdades de agronomia, conforme pode-se constatar no depoimento do professor titular de Fitossanidade da Escola Superior de Agricultura de Lavras/MG, Luis Onofre Salgado, em entrevista publicada na revista "A Granja", em março de 1989.

"...Os engenheiros agronômos, na sua maioria, estão saindo das universidades e das escolas de agronomia sem o devido treinamento na área específica. É necessário 
que se inclua nos currículos plenos dos cursos de Agronomia conteúdos que tratam a tecnologia de aplicação....É preciso que os engenheiros agrônomos estejam melhor preparados na área de defesa fitossanitária como um todo....nossas escolas não implementam a parte toxicológica dentro dos cursos de Agronomia. ...Emitir uma receita e não dar assistência técnica é totalmente errado. Ele tem de ir, acompanhar a aplicação, pelo menos a primeira aplicação, para ver se tudo está de acordo com o programado" (A Granja, março, 1989:22-23).

Desde o início do ano de 1989, intensificavam-se as discussões sobre a necessidade de uma legislação federal a regular a questão dos agrotóxicos. As lutas e os percalços experimentados nas inicativas levadas a efeito nos diversos estados que tentavam a solução local, serviam de base para a proposição de um instrumento geral ao nível federal.

\section{3. A lei federal dos agrotóxicos}

Com a aprovação da Lei Federal $n^{0}$ 7.802, em 11 de julho de 1989, e sua regulamentação pelo Decreto $n^{\circ} 98.816$, de 11 de janeiro de 1990, estaria vencida uma das etapas importantes na tentativa de organizar e dar consistência ao processo de regulamentação dos agrotóxicos em todas as etapas de seu ciclo de produção, comercialização e uso.

Anteriormente à existência da Lei 7.802/89 a base legal que regulava o tema era constituída de um conjunto complexo e burocratizado de Portarias e Regulamentos Ministeriais emanados nos âmbitos de ação das Pastas de Agricultura, Saúde e Meio Ambiente. A grande maioria dessas normas anterior tinha como instrumento básico legal o Regulamento de Defesa Sanitária Vegetal, aprovado pelo Decreto Federal $\mathrm{n}^{\mathrm{o}}$ 24.114, de 12 de abril de 1934.

Os principais aspectos regulados pela nova legislação abrangem os seguintes pontos: 
a) estabelece as regras para os processos de registro:

- novos produtos: somente se a sua ação tóxica sobre o ser humano e o meio ambiente for comprovadamente igual ou menor do que a daqueles já registrados, para o mesmo fim;

- proibido o registro de produtos:

○ para os quais o Brasil não disponha de método de desativação de seus componentes, de modo a impedir que os seus resíduos remanescentes provoquem riscos ao ambiente e à saúde pública;

- para os quais não haja antídoto ou tratamento eficaz no Brasil;

- que revelem características teratogênicas, carciogênicas ou mutagênicas;

○ que provoquem distúrbios hormonais ou danos ao aparelho reprodutor;

- que se revelem mais perigosos para o homem do que os testes de laboratório com animais tenham podido demonstrar;

○ cujas características causem danos ao meio ambiente.

b) atribui legitimidade às entidades de classe das profissões ligadas ao setor, aos partidos políticos, e às entidades de defesa dos consumidores, do meio ambiente $\mathrm{e}$ dos recursos naturais, para a requisição do cancelamento ou impugnação do registro de produtos, argüindo prejuízos ao meio ambiente, à saúde humana e dos animais;

c) estabelece requisitos de segurança para as embalagens dos produtos;

d) dispõe sobre o conteúdo e a forma das bulas e rótulos;

e) estabelece critérios para a propaganda comercial dos agrotóxicos;

f) define as competências da União, dos Estados e dos Municípios, a saber:

- União: 
- legislar sobre a produção, registro, comércio interestadual, exportação, importação, transporte, classificação e controle tecnológico e toxicológico;

- controlar e fiscalizar os estabelecimentos de produção, importação, e exportação;

○ analisar os produtos nacionais e importados

- Estados:

- legislar sobre o uso, produção, consumo, comércio, e armazenamento;

○ fiscalizar o uso, o consumo, o comércio, o armazenamento e o transporte interno;

- Municípios:

- Legislar supletivamente sobre o uso e o armazenamento dos agrotóxicos.

g) institui a venda de agrotóxicos por receituário próprio, prescrito por profissionais legalmente habilitados;

h) define as responsabilidades administrativas, civis e penais, pelos danos causados à saúde das pessoas e ao meio ambiente. Tais responsabilidades são atribuídas aos profissionais, aos usuários, aos comerciantes, aos registrantes, aos produtores dos agrotóxicos, e aos empregadores das unidades de produção onde se faça o uso de agrotóxicos.

i) estipula as sanções cabíveis pelo não atendimento aos dispositivos da lei.

O estabelecimento da necessidade de receituário agronômico para a comercialização dos agrotóxicos foi definido no artigo $13^{\circ}$ da Lei 7.802/89 :

"Art.13- A venda de agrotóxicos e afins aos usuários será feita através de receituário próprio, prescrito por profissionais legalmente habilitados, salvo casos excepcionais que forem previstos na regulamentação desta Lei." 
No Decreto n98.814, que regulamenta a lei dos agrotóxicos, o tema "receituário" é título de um dos capítulos (VI) divididos em quatro artigos específicos. Neles são definidos os conceitos de usuário e de profissional habilitado, além de serem desenhados os tópicos que caracterizam o conteúdo mínimo que deve estar presente na receita, a saber:

- nome e endereço completo do técnico responsável, e número de seu registro no Conselho Regional Profissional;

- $\quad$ nome do consulente, da propriedade e sua localização;

- recomendação técnica com as seguintes informações:

$\Rightarrow$ nome do produto comercial que deverá ser utilizado;

$\Rightarrow$ cultura e área onde será aplicado;

$\Rightarrow$ dosagens de aplicação e quantidades totais a serem adquiridas;

$\Rightarrow$ modalidade de aplicação, sendo que no caso de aplicação aérea devem ser registradas as instruções específicas;

$\Rightarrow$ época de aplicação;

$\Rightarrow$ intervalo de segurança;

$\Rightarrow$ precauções de uso;

$\Rightarrow$ primeiros socorros nos casos de acidentes;

$\Rightarrow$ advertências relacionadas à proteção do meio ambiente;

$\Rightarrow$ instruções sobre a disposição final de resíduos e embalagens;

$\Rightarrow$ orientações quanto ao manejo integrado de pragas;

$\Rightarrow$ data, assinatura e carimbo do técnico, com indicação do nome, do registro no Conselho Regional Profissional e do CPF.

O posicionamento dos diversos setores envolvidos com a questão do receituário, por ocasião da aprovação da lei dos agrotóxicos pode ser exemplificado pelo conteúdo de reportagem publicada no jornal "Folha de São Paulo", de 18 de abril de 1989, sob o título "Receituário para defensivo depende do governo". Alguns trechos do artigo ilustram o contexto de aplicação da lei: 
"Os fabricantes de defensivos agrícolas - que durante muito tempo se mostraram contrários ao uso de receituário para a compra de defensivos - e os produtores rurais estão favoráveis à obrigatoriedade da utilização de um formulário agronômico para a aquisição dos produtos altamente tóxicos(...).

(...) Cristiano Walter Simon, 47, vice-presidente executivo da Associação Nacional de Defensivos Agrícolas (Andef), afirma que os fabricantes são favoráveis ao uso de receituário. "Muitos agrônomos não queriam usá-lo antes, pois nunca ficou bem claro até que ponto o engenheiro agrônomo era responsável pelos efeitos ou pelo mau uso do produto indicado", afirma Simon (...)

(...) Agora, o Conselho Regional de Engenharia, Arquitetura e Agronomia (Crea) pretende, com a instrução que vai baixar, "deixar claro que a responsabilidade do profissional se limita à emissão correta e adequada da receita. Se o agricultor fizer um uso incorreto, a responsabilidade por problemas de saúde ou danos ecológicos será inteiramente dele”, diz Simon, que também faz parte da diretoria da Associação de Engenheiros do Estado (...)

(...).Os produtores rurais apoiam o uso do receituário e acreditam que não vão ter qualquer transtorno quando a lei realmente for cumprida. Carlos Ankaru, presidente do Sindicato Rural de Suzano e membro da Comissão Técnica de Hortifrutigranjeiros da Federação de Agricultura do Estado de São Paulo (Faesp), afirma que os abusos na utilização de defensivos precisam acabar. "Com receituário vão ser beneficiados os produtores e consumidores", afirma."

Em outro trecho da mesma reportagem é apresentado o ponto de vista do órgão regional do Ministério da Agricultura no estado de São Paulo, ressaltando as condições necessárias para a efetivação da aplicação do instrumento da receita:

“(...) A fiscalização da Secretaria da Agricultura em relação ao uso do receituário agrícola terá de ser muito eficiente. Se isso não acontecer, pode surgir uma "indústria”, que tente ganhar em cima do agricultor. O alerta é feito pelo chefe do 
Serviço de Defesa Vegetal da Delegacia Federal de Agricultura em São Paulo, José Tadeu de Faria. Ele acha que não basta fazer cumprir a lei, mas, sim dar uma assistência correta aos produtores, prestada por profissionais que não sejam ligados a fabricantes de defensivos (...)

(...) Tadeu de Faria diz que a secretaria precisa contar com mais agrônomos $e$ definir quem vai fiscalizar e quem vai fazer as prescrições. "Acho complicado o mesmo agrônomo receitar e fiscalizar o cumprimento da lei. Além disso, para receitar, o profissional deveria ter formação especifica. Normalmente o agrônomo tem uma formação muito eclética(...)"

A aprovação da chamada "lei dos agrotóxicos" e seu decreto regulamentador trouxe grande alento para os grupos de ambientalistas e de profissionais envolvidos na luta contra o uso indiscriminado dos agrotóxicos.

As campanhas iniciadas no Rio Grande do Sul e levadas à diante por mais de uma década, em todo o território nacional, haviam surtido efeito esperado, ao menos no aspecto legal da questão, conforme reportagem publicada à época pela revista "Dirigente Rural":

"Agora, depois de cerca de uma década de lutas e decepções, os que defendem restrições mais severas a esses insumos têm motivo para comemorar(...) Esta é a opinião de Walter Lazzarini Filho, secretário de Agricultura e Abastecimento do Estado de São Paulo que, como deputado estadual, teve duas leis de sua iniciativa (4.002, de 5 de janeiro de 1984 e 5.032, de 15 de abril de 1986) promulgadas pelo Governo paulista, (...) Ambas, no entanto, não vingaram, devido à decisão da Justiça, podendo agora, serem promulgadas" (Dirigente Rural, setembro, 1989:16).

Um dos pontos mais importantes da legislação federal dos agrotóxicos estava relacionado ao estabelecimento das competências dos Estados em legislar sobre a matéria, conforme destacava Lazzarini, na citada reportagem. 
"A lei reforça o que foi estabelecido pela nova Constituição nos seus artigos 23 e 24. Isto é, de agora em diante os Estados é que legislam sobre o assunto - aspecto altamente positivo - pois cada um tem condições e necessidades diferente." (Dirigente Rural, setembro, 1989:16).

A importância do estabelecimento do receituário agronômico também era ressaltada como um ponto de avanço da nova lei dos agrotóxicos, conforme observou Lazzarini:

"Antes não havia nenhuma restrição para a venda e aplicação dos produtos. Nunca houve tal preocupação, sequer em relação à segurança do aplicador. Hoje, dispomos de um instrumento para impedir que isso continue a acontecer" (Dirigente Rural, setembro, 1989:16).

As indagações levantadas sobre a efetividade da adoção do receituário agronômico como medida de controle eram descartadas por seus proponentes, envolvidos pela visão de inovação trazida pelo instrumento, reforçadas pelo sucesso das experiências bem sucedidas dos estados do sul do país.

"Muito já se falou na receita assinada em branco, podendo denegrir a classe. Mas essa classe é formada por pessoal consciente de suas responsabilidades. Em todo o caso, os profissionais desonestos ou incompetentes serão punidos como estabelece a lei. Em vez de prejudicar a categoria, isso contribuirá para dar-lhe maior credibilidade, argumenta Lazzarini" (Dirigente Rural, setembro, 1989:16).

As críticas à nova lei, apresentadas por setores empresariais, sobretudo em relação ao suposto aspecto burocratizante representado pela implantação do receituário agronômico eram prontamente rebatidas pelos defensores do mecanismo, com argumentos muitas vezes surpreendentes, a exemplo do exposto em reportagem da revista "Dirigente Rural", em junho de 1990: 
"Alguns agrônomos que participaram ativamente da discussão e elaboração da Lei dos Agrotóxicos são bastante objetivos com relação aos motivos que os levaram a elaborar essa legislação. É o caso do ex-presidente da Federação das Associações dos Engenheiros Agrônomos do Brasil (FAEAB), o gaúcho Floriano Barbosa Isolan. Não há a menor dúvida, diz, de que o receituário agronômico burocratiza a venda desses venenos, mas a idéia é essa mesma, é dificultar a comercialização desses produtos" (Dirigente Rural, junho/julho, 1990:10).

\section{4. O distanciamento da idéia inicial}

Com a aprovaçõa da Lei $\mathrm{n}^{\mathrm{o}} 7.802 / 89$, vários estados passaram a reformular ou apresentar novas leis sobre a matéria. A idéia inicial do receituário agronômico como instrumento metodológico para abordagem técnica dos problemas fitossanitários na produção agrícola e florestal vai cada vez mais perdendo espaço. O processo legislativo e as decorrentes medidas administrativas implantadas, tanto no âmbito da fiscalização do uso, sob responsabilidade dos órgãos de defesa sanitária vegetal, como na fiscalização do exercício profissional, sob responsabilidade do sistema CONFEACREA, vão caracterizando o instrumento do receituário agronômico como um sistema de controle de vendas.

As discussões agora restringem-se aos modelos de formulários, às rotinas de procedimentos burocráticos, ao número de vias a constar nas receitas, aos aspectos punitivos da legislação, enfim, já parece distante o entendimento dos conceitos iniciais da doutrina preconizada por GUERRA \& SAMPAIO, para o receituário agronômico, ao início das campanhas no Rio Grande do Sul.

Um dos exemplos do reducionismo aplicado aos preceitos do receituário agronômico pode ser verificado na inclusão de textos padronizados nos versos dos formulários de receitas, divulgando recomendações técnicas previamente estabelecidas. 
"...A demanda pelo receituário agronômico está aumentando em todo o Estado de São Paulo...As Casas de Agricultura do Estado receberam os receituários agronômicos adotados pela Coordenadoria de Assistência Técnica Integral (CATI) (...) Além de conter recomendações técnicas para cada tipo de produto utilizado, o formulário traz no verso informações complementares, como precauções no uso de agroquímico e orientação sobre primeiros socorros em caso de acidente (...) Os técnicos lembram que a receita é emitida em cinco vias, sendo que a primeira permanece com o estabelecimento comercial; a segunda fica em poder do usuário; a terceira se destina ao profissional que a prescreveu; a quarta é enviada ao Conselho Regional de Engenharia, Arquitetura e Agronomia; e a última cabe ao órgão estadual competente, no caso a CATI." (Dirigente Rural, outubro, 1990:27).

Os debates sobre a operacionalização do receituário agronômico vão ocorrendo em todo o país, na medida em que os estados vão desenvolvendo novas legislações, agora seguindo os preceitos estabelecidos pela lei federal (Lei $\left.\mathrm{n}^{\mathrm{o}} 7.802 / 89\right)$.

Mas o caráter burocrático das discussões supera completamente as questões técnicas básicas em torno da prática do receituário, e os principais pontos das discussões e das ações desenvolvidas dizem respeito aos processos, aos fluxos, aos formulários, à fiscalização, distorcendo o real objetivo do instrumento, com resultados visíveis na efetividade de sua aplicação; conforme se pode observar no editorial do "Jornal do Engenheiro Agrônomo", publicado pela Associação de Engenheiros Agrônomos do Estado de São Paulo, em novembro de 1990.

"A visita prévia à propriedade consta da lei estadual e deve ser seguida rigorosamente, pois o cumprimento desta exigência será cobrado se ocorrer algum problema no campo. Algumas cooperativas já estão montando esquemas de acompanhamento das propriedades rurais a que dão assistência técnica....A AEASP discutiu em reunião de seu Conselho Deliberativo e aprovou um ato a ser decretado pelo CREA-SP para controlar números elevados de receitas prescritas por profissionais em período curto. O engenheiro agrônomo e outros envolvidos, lojas, cooperativas, empresas, devem ter consciência da importância da receita correta e 
unirem suas ações neste sentido" (Jornal do Engenheiro Agrônomo, outubro/novembro, 1990:2).

Diversas foram as tentativas de correção dos problemas encontrados na operacionalização do receituário agronômico nos vários estados, em especial na região sul e sudeste do país. Os Conselhos Profissionais buscavam aprovar dispositivos legais que viessem a regular as distorções detectadas em torno da prática do receituário agronômico. Entretanto muitas vezes os próprios mecanismos concebidos e estabelecidos pelos CREA's traziam aspectos contraditórios com a doutrina inicial do receituário agronômico.

Um exemplo destas distorções pode ser observado nas discussões, resoluções e deliberações que estabeleceram critérios sobre o número máximo de receitas a serem emitadas por profissionais, em cada período.

Alguns conselhos profissionais tomaram como parâmetro aceitável a emissão de até 300 receitas por mês, para cada profissional. Isto na prática significa abrir a possibilidade de emissão de mais de 10 receitas por dia de trabalho do profissional, o que certamente não pode guardar relação com os preceitos metodológicos preconizados na doutrina incial do receituário agronômico, incluindo as visitas às propriedades e o cumprimento dos passos da chamada semiotécnica agronômica.

São estas contradições estampadas periodicamente na imprensa, dando conta dos problemas da venda indiscriminada de agrotóxicos e da ineficácia do receituário agronômico, que vão distanciando o instrumento de seus objetivos iniciais, fazendo com que a legitimidade da iniciativa seja perdida na burocratização de sua implantação. 


\section{O FEITIÇO VIRA CONTRA O FEITICEIRO: A BANALIZAÇÃO DAS ATIVIDADES DO RECEITUÁRIO}

Os problemas decorrentes da efetiva aplicação dos preceitos concebidos para o receituário agronômico começam a surgir, de forma mais intensa, a partir das tentativas de implantação decorrentes das disposições da nova lei de agrotóxicos aprovada no Congresso em 1989.

Em 1992, o jornal "Folha de São Paulo", em sua edição de 19 de janeiro, publicou uma reportagem com o título: "Repórter compra receita em loja e leva agrotóxico capaz de matar 35". Tal reportagem denunciava a facilidade encontrada para o acesso à compra de um agrotóxico, sem o cumprimento dos passos previstos nos regulamentos estabelecidos para a questão. Além disto a referida matéria mostrava ainda as dificuldades operacionais na implantação do receituário agronômico, e o papel do profissional técnico neste contexto.

As denúncias dos problemas envolvendo o controle dos agrotóxicos e as dificuldades encontradas na implementação efetiva do receituário agronômico, nos diversos estados que buscavam institucionalizar o instrumento, fizeram com que várias discussões fossem organizadas a respeito do tema. Tais esforços, no âmbito da corporação agronômica, se concretizaram na realização periódica de congressos especificamente voltados para o tema do receituário agronômico .

Mas, longe de cumprir com os supostos objetivos de correção das distorções apresentadas pela prática do receituário agronômico, os congressos dedicados aos agrotóxicos e ao receituário agronômico acabaram por reforçar o caráter contraditório 
da questão, pois foram realizados sem maiores preocupações, por exemplo, com a memória técnica das eventuais deliberações tomadas pela categoria participante dos eventos, e não conseguiram impulsionar a efetivação das propostas levadas nas discussões realizadas. Assim pode-se constatar que somente a quarta edição do "Congresso Nacional de Agrotóxicos e Receituário Agronômico", realizado na cidade de Goiânia, em setembro de 1998, teve os anais publicados e divulgados, o mesmo não acontecendo com os eventos anteriores.

Algumas das propostas aprovadas na plenária final do evento realizado na cidade de Goiânia, retratam bem as dificuldades e os problemas encontrados pela corporação agronômica, nas tentativas de implantação e prática dos preceitos do receituário agronômico, conforme mostrado a seguir.

"Os profissionais reunidos no IV CNARA indicam ao sistema CONFEA/CREA'S a urgente necessidade de limitar o número de Receitas Agronômicas emitidas por profissional, bem como, fiscalizar cooperativas e lojas de vendas de agrotóxicos no varejo que"obrigam" seus técnicos a emitirem receitas em quantidade maior do que os CREA's recomendam" (Anais do IV CNARA, setembro, 1998:111).

Esta proposta se justificava pela ausência de instruções dos CREA's de alguns estados, no estabelecimento de parâmetros para a prática do receituário agronômico. Mas o curioso é observar que os estados que já contavam com critérios estabelecidos, e que, supostamente, estariam a servir de exemplo aos demais, atendiam a parâmetros absolutamente inviáveis para o real cumprimento da doutrina semiotécnica do receituário agronômico, na medida em que estabelecem, por exemplo, a possibilidade de emissão de 300 receitas/mês, para cada profissional.

"Ir às Universidades para solicitar melhor preparo do futuro profissional quanto à ética e receituário agronômico ...Que as Associações Regionais façam mais reuniões sobre o assunto, Receituário e Ética....Que o CREA oriente melhor o profissional e não só fiscalize....Que o CREA selecione e prepare melhor seu profissional de Campo" (Anais do IV CNARA, setembro, 1998:111). 
A constatação da ausência de conteúdos técnicos específicos sobre temas como receituário agronômico, agrotóxicos, e toxicologia, nos currículos dos cursos das áreas de ciências agrárias, tem sido sistematicamente apontada pela corporação agronômica, sem contudo propiciar iniciativas abrangentes de mudanças.

"Reverter os processos de desmantelamento das Instituições Públicas Federais Estaduais e Municipais de Agricultura, Meio Ambiente e Saúde, dotando-as de recursos humanos, materiais e financeiros, de forma que possam ser implantadas ações de controle e fiscalização do uso indiscriminado e inadequado de agrotóxicos, possibilitando inclusive a assistência técnica ao produtor rural" (Anais do IV CNARA, setembro, 1998:111).

Os processos de deterioração e esvaziamento dos serviços oficiais de assistência técnica, extensão rural, e de pesquisa pública no país certamente têm contribuído para o agravamento dos problemas decorrentes do uso indiscriminado dos agrotóxicos no campo.Esse sentimento é partilhado pela corporação agronômica que reivindica ainda a melhoria dos sistemas de fiscalização exercidos no âmbito dos serviços de defesa sanitária vegetal, nas secretarias estaduais de agricultura.

"Que as propostas de solicitação de alterações dos artigos do Decreto 98.816/90 apresentadas e aprovadas no último congresso sejam ratificadas, facilitando a simplificação e implementação do receituário agronômico" (Anais do IV CNARA, setembro, 1998:111).

Esta proposta demonstra o caráter inócuo das proposições levantadas pela categoria nos congressos anteriores, tendo em vista a permanência dos mesmos problemas antes detectados, agora agravados, e a pouca interlocução da corporação com os demais atores envolvidos na questão dos agrotóxicos, de forma a poder dar seguimento prático aos pontos levantados nas discussões da categoria. 
"Que seja valorizada e divulgada a atuação do profissional autônomo e das empresas públicas e privadas na assistência técnica e emissão de receitas, inclusive como forma de combater o profissional de balcão" (Anais do IV CNARA, setembro, 1998:111).

Aqui a linguagem utilizada já demonstra o nível do distanciamento da prática do receituário agronômico, em relação aos preceitos iniciais: não se trata mais de buscar o reconhecimento profissional pela atuação técnica competente na resolução dos problemas de manejo das pragas e doenças nas atividades agropecuárias e florestais, a questão agora se resume em buscar a valorização dos profissionais "na emissão de receitas". O termo "profissional de balcão" é bastante ilustrativo dos problemas decorrentes das contradições encontradas na operacionalização do receituário agronômico.

" (..) que seja dado aos produtos agrotóxicos o mesmo tratamento dado, na propaganda, aos medicamentos, segundo a lei 9.294/96, onde a propaganda somente poderá ser feita em publicações especializadas dirigidas aos técnicos" (Anais do IV CNARA, setembro, 1998:114).

Este ponto ressalta outra contradição importante na questão do receituário agronômico: a propaganda comercial. A lei federal dos agrotóxicos, aprovada em 1989, e o decreto que a regula, trazem os parâmetros a serem observados no tocante a propaganda comercial. Tais parâmetros estão de acordo com os preceitos estabelecidos pela FAO, no "Código Internacional de Conduta para a Distribuição e Utilização de Praguicidas", aprovado inicialmente em 1985, com o objetivo de ajudar os países membros, no estabelecimento de regulamentos e normas para a aplicação de práticas comerciais responsáveis em relação aos agrotóxicos.

Assim, a lei dos agrotóxicos no Brasil estabeleceu novos requisitos para a propaganda comercial dos produtos. Propagandas estas que eram alvo de várias críticas sobre os aspectos éticos adotados até então. 
BARZOTTO (1992), ao estudar as propagandas de agrotóxicos no Brasil, identifica dois eixos tomados como base para a propaganda dos agrotóxicos: o ocultamento da periculosidade dos produtos divulgados, e a busca de autorização em outros saberes do dizer favorável ao consumo.

"...Através da identificação das estratégias de ocultamento tornou-se possível desvendar a naturalização do consumo de produtos agrotóxicos, no interior de um movimento de discurso que apresenta a trajetória da ideologia da modernização (...)

(...) Para o agricultor as vantagens traduzem-se em produtividade, gerando a idéia de ascensão social, enquanto para técnicos e consumidores, isso aparece para fazer crer que o uso desses produtos pode garantir a alimentação da humanidade (...)

(...) A prática discursiva da propaganda, ocultando tal periculosidade, ressalta vantagens e faz isso articulando enunciados de diferentes saberes (discurso científico, religioso, senso comum, etc) para levar o agricultor ao modo de produção agrícola exigido pela ideologia do desenvolvimento e da modernização" (BARZOTTO, 1992).

Os dispositivos agregados à lei federal de agrotóxicos, em 1989, colocaram um novo patamar para os requisitos a serem observados nas propagandas comerciais dos agrotóxicos.

Entretanto, em 1996, o governo federal encaminha e aprova no Congresso a lei $\mathrm{n}^{\circ}$ 9.294, específica para regular a propaganda comercial de produtos fumígeros, bebidas alcoólicas, medicamentos, terapias e "defensivos agrícolas" (termo usado na lei, mesmo em contradição com a definição de agrotóxicos na lei 7.802/89).

A lógica empregada para os medicamentos, que direciona a propaganda para publicações especializadas dirigidas direta e especificamente a profissionais e instituições de saúde, não é a mesma definida para os agrotóxicos. Para estes a lei estabelece que a propaganda deverá restringir-se a programas e publicações dirigidas 
aos agricultores e pecuaristas, mostrando claramente quem é o interlocutor privilegiado na difusão da tecnologia de risco representada pelos agrotóxicos.

Assim a contradição fica regulamentada: por um lado se estabelece a necessidade da prescrição técnica por profissional responsável habilitado, como requisito para a compra dos agrotóxicos; por outro se define o público alvo das propagandas comerciais de agrotóxicos: o usuário final.

A proposta apresenta no IV Congresso sobre receituário agronômico, referente à propaganda comercial, citada anteriormente, buscava denunciar tal contradição.

Um resumo das reivindicações e proposições levadas pela corporação agronômica, na quarta versão do congresso organizado para discussão do receituário agronômico, pode ser observado a partir do conteúdo da chamada "Carta de Goiânia" aprovada como um dos documentos finais do evento, transcrita a seguir:

\section{"Carta de Goiânia}

nos termos que se seguem:

É constrangedora a constatação da permanente falta de sensibilidade dos governos estaduais e federal para a adoção de medidas que transformem em rotina o controle do uso indiscriminado de agrotóxicos, cujos danos já são de domínio público, com dimensões que ultrapassam os limites de tolerância que a sociedade pode suportar, apesar dos esforços e dedicação da categoria agronômica.

Ao contrário do que as promessas apontam, a falta de investimentos nos órgãos da Agricultura, Saúde e Meio Ambiente, só têm agravado o nível dos problemas crônicos que acompanham a trajetória do emprego de agrotóxicos no País.

O desmonte da estrutura do Estado em nome do equilibrio orçamentário não pode destruir as instituições que garantam por meio de seus diferentes segmentos de 
fiscalização a saúde e qualidade de vida da população, limitando a ação dos profissionais habilitados, prejudicando os produtores rurais, desmerecendo os serviço público, não interessando à indústria e ao comércio e, sobretudo, contaminando o meio ambiente e os consumidores.

Às vésperas das eleições para os cargos legislativos e executivos, tanto em nível federal quanto estadual, requer-se de forma imperiosa a cobrança de compromissos formais dos futuros ocupantes de tais cargos, não de uma forma ingênua e crédula, mas através de documentos, registrados oficialmente e divulgados amplamente, com o objetivo de reverter a problemática.

A possibilidade de importação de agrotóxicos através de mecanismos tortuosos, com burla do espirito da legislação brasileira para atender aos Acordos do MERCOSUL, mereceu a discordância de todos os participantes deste IV CNARA e deve servir de alerta às autoridades brasileiras sobre as conseqüências de uma "globalização" danosa aos consumidores de alimentos e à preservação ambiental.

É imprescindivel o aperfeiçoamento da legislação vigente, no entanto, rejeitamos qualquer mudança que não passe por uma ampla discussão com a sociedade e efetiva participação dos profissionais da agronomia.

A necessidade de serem feitos aperfeiçoamentos aos instrumentos da ação profissional, como é o caso da receita agronômica, não pode servir de pretextos para desvirtuar a legislação,nem para se retroceder nas conquistas das lutas lideradas pela FAEAB e Associações Estaduais de Engenheiros Agrônomos e de Engenheiros Florestai." (Anais do IV CNARA, setembro, 1998:119).

O conteúdo diversificado da carta apresentada, e a linguagem confusa adotada em sua redação, exemplificam um pouco a miscelânea de discursos estabelecidos nas recentes discussões levadas no âmbito da corporação agronômica, sobre os agrotóxicos e o receituário agronômico. 
As deliberações do último congresso sobre receituário agronômico realizado no Rio de Janeiro, em agosto de 2000, retomam as contradições e os problemas antes identificados em torno dos agrotóxicos, e revelam ainda a situação de desconforto vivida pelos atores responsáveis pela intermediação técnica nas atividades de manejo das pragas e doenças na agricultura, na medida em que os mesmos problemas, identificados nos congressos anteriores, surgem novamente nas pautas de discussões, sem que tenham sido resolvidos anteriormente. Os tópicos a seguir resumem as principais propostas aprovadas pelos congressistas

- alterar a legislação dos agrotóxicos, definindo a exclusividade dos profissionais de nível superior nas atividades de prescrição das receitas, tendo em vista a possibilidade atual de prescrição feita por técnicos de nível médio;

- estabelecer ações de fiscalização integrada, envolvendo os órgãos de defesa agropecuária, os conselhos profissionais, o ministério público, dentre outros, atuando diretamente junto aos estabelecimentos rurais, implementando a fiscalização do uso de agrotóxicos;

- desenvolver atividades de divulgação do papel do receituário agronômico junto aos produtores rurais;

- promover alterações legais que venham a permitir a prescrição de recomendações não contidas nos rótulos e bulas dos agrotóxicos, mas que tenham respaldos em dados de pesquisas regionais;

- resgatar e implementar as propostas aprovadas no IV CNARA (congresso anterior);

- requerer do Ministério da Saúde a obrigatoriedade de notificação de intoxicações por agrotóxicos, e o repasse desta informação aos órgãos fiscais da agricultura;

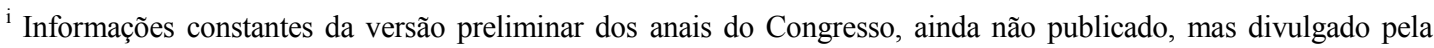
secretaria do evento, por solicitação, através de correio eletrônico, em agosto de 2000.
} 
- incluir disciplinas específicas sobre receituário agronômico, nos currículos dos cursos de ciências agrárias;

- desenvolver cursos de capacitação como requisitos para a atuação nas atividades de receituário agronômico;

- resgatar o papel do receituário agronômico no controle do uso de agrotóxicos;

- implementar, de forma eficiente, a fiscalização em todos os Estados;

- cumprir imediatamente os dispositivos legais que preconizam o fornecimento de relatórios semestrais sobre os produtos comercializados; e que essa informação seja sistematizada pelos órgãos de defesa agropecuária, servindo como base para o planejamento público nas áreas de: mapeamento dos riscos, estudos epidemiológicos de pragas, doenças, intoxicação, etc. 


\section{1. A ineficácia do sistema de receituário agronômico}

Um dos indicadores possíveis para se avaliar a eficácia do sistema atual de receituário agronômico, para o controle do uso indiscriminado de agrotóxicos, pode ser sugerido a partir da análise do comportamento das vendas de agrotóxicos após a implantação genérica desse instrumento, a partir da lei dos agrotóxicos, em 1989.

Considerando-se o volume físico dos agrotóxicos comercializados no Brasil, o consumo em produto comercial, nos últimos dez anos, cresceu o equivalente a uma taxa anual de $6,7 \%$.

No tocante às classes de produtos, os mais consumidos foram os herbicidas. Este grupo que em 1987 era responsável por 40\% do volume físico em produto comercial utilizado, em 1997 representou cerca de 53\% das quantidades consumidas, mostrando um crescimento equivalente a uma taxa anual de $9,8 \%$ ao longo do período entre 1987 e 1997.

O crescimento das demais classes correspondeu a taxas anuais de 3,4\% para inseticidas e fungicidas e $11,2 \%$ para os acaricidas. Estes últimos, não obstante o pequeno peso relativo face ao total comercializado em 1997 (5,6\%), mostraram um consumo praticamente triplicado em dez anos; incremento este maior ainda que os herbicidas cujo aumento na quantidade comercializada foi da ordem de 2,5 vezes.

A distribuição das quantidades de agrotóxicos comercializados no Brasil, em 1987 e 1997, em termos de produto comercial e de ingrediente ativo, segundo as classes de produtos é mostrada a seguir: 
Tabela 20 - Quantidades* de agrotóxicos comercializados, em produto comercial e ingrediente ativo, segundo as diferentes classes de produtos - Brasil 1987 e 1997

\begin{tabular}{|c|c|c|c|c|c|c|c|c|}
\hline \multirow[t]{2}{*}{ Classe } & \multicolumn{4}{|c|}{1987} & \multicolumn{4}{|c|}{1997} \\
\hline & $\begin{array}{c}\text { Produto } \\
\text { Comercial }\end{array}$ & $\begin{array}{l}\% \text { do } \\
\text { total }\end{array}$ & $\begin{array}{c}\text { Ingrediente } \\
\text { ativo }\end{array}$ & $\begin{array}{l}\% \text { do } \\
\text { total }\end{array}$ & $\begin{array}{c}\text { Produto } \\
\text { comercial }\end{array}$ & $\begin{array}{l}\% \text { do } \\
\text { total }\end{array}$ & $\begin{array}{l}\text { Ingrediente } \\
\text { ativo }\end{array}$ & $\begin{array}{c}\% \text { do } \\
\text { total }\end{array}$ \\
\hline Herbicidas & 51936 & $(39,5)$ & 24471 & $(42,7)$ & 132.574 & $(52,8)$ & 61.885 & $(58,8)$ \\
\hline Inseticidas & 45993 & $(35,0)$ & 14109 & $(24,6)$ & 64.420 & $(25,7)$ & 16.218 & $(15,4)$ \\
\hline Fungicidas & 28687 & $(21,8)$ & 17545 & $(30,6)$ & 40.133 & $(16,0)$ & 17.369 & $(16,5)$ \\
\hline Acaricidas & 4849 & $(3,7)$ & 1237 & $(2,16)$ & 14.014 & $(5,6)$ & 9.835 & $(9,3)$ \\
\hline Total & 131465 & $(100,0)$ & 57362 & $(100,0)$ & 251.141 & $(100,0)$ & 105.307 & $(100,0)$ \\
\hline
\end{tabular}

*toneladas - Fonte: modificado de Sindicato Nacional da Indústria de Defensivos Agrícolas (SINDAG) e de http://www.iea.sp.gov.br/defens98.htm

Tomando-se como base os níveis de consumo estabelecidos em 1975, verifica-se um comportamento diferenciado das diversas classes de agrotóxicos, nas vendas efetuadas ao longo dos últimos vinte anos no Brasil.

O consumo de herbicidas apresentou um intenso incremento, crescendo cerca 5,4 vezes entre os anos de 1978 e 1998.

A classe dos fungicidas apresentou um crescimento moderado, realizando em 1998 um acréscimo em cerca de duas vezes os valores consumidos em 1978.

Já na classe dos inseticidas verifica-se uma discreta redução nos níveis de consumo, os quais representaram, em 1998, cerca da metade dos valores de 1975.

As figuras 25 e 26 ilustram o comportamento das quantidades de produtos comerciais e ingredientes ativos dos agrotóxicos comercializados no Brasil, entre os anos de 1978 e 1998. 
Figura 25 - Evolução dos índices percentuais simples das quantidades vendidas de produto comercial, em diversas classes de agrotóxicos - Brasil - 1978, 1988 e 1998 (ano base 1975=100)

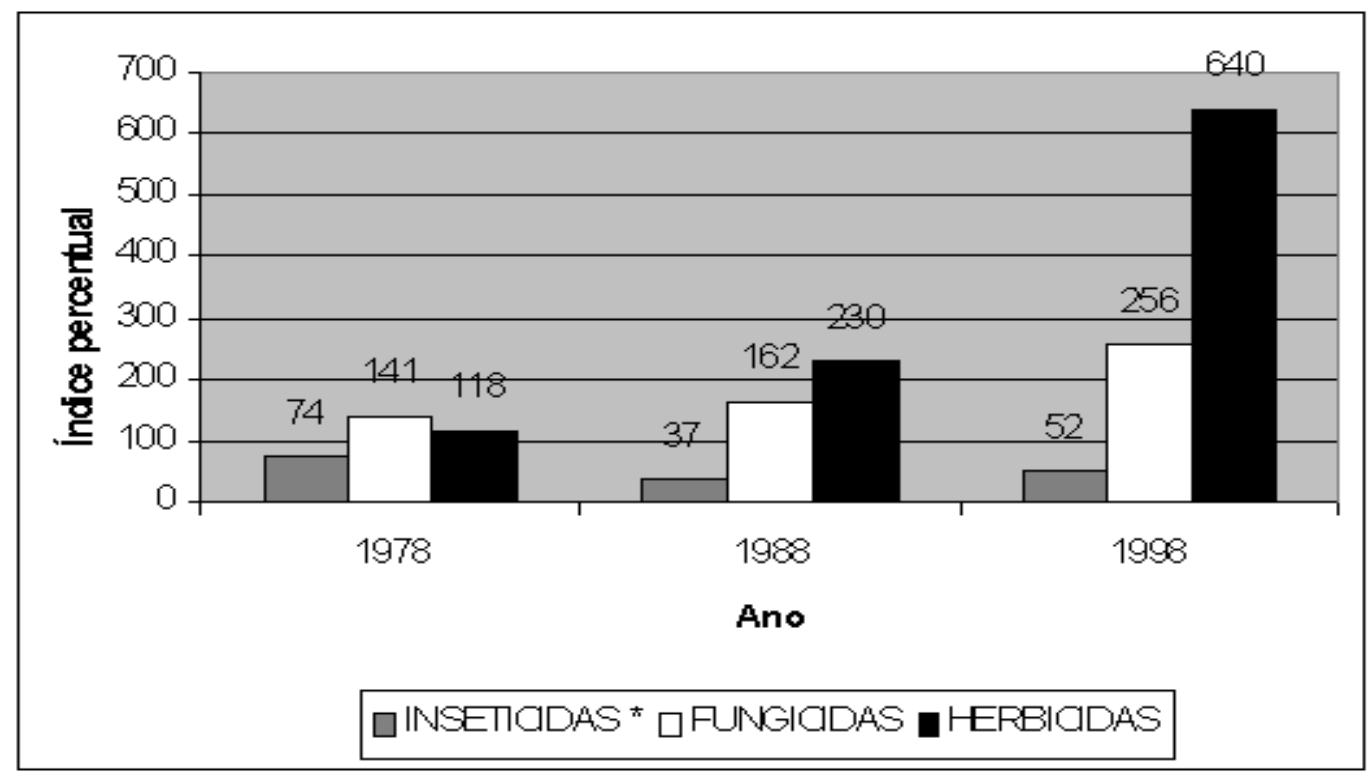

Fonte: elaboração própria, a partir dos dados das tabelas 7 a 10 .

Figura 26 - Evolução dos índices percentuais simples das quantidades vendidas de ingrediente ativo, em diversas classes de agrotóxicos - Brasil - 1978, 1988 e 1998 (ano base 1975=100)

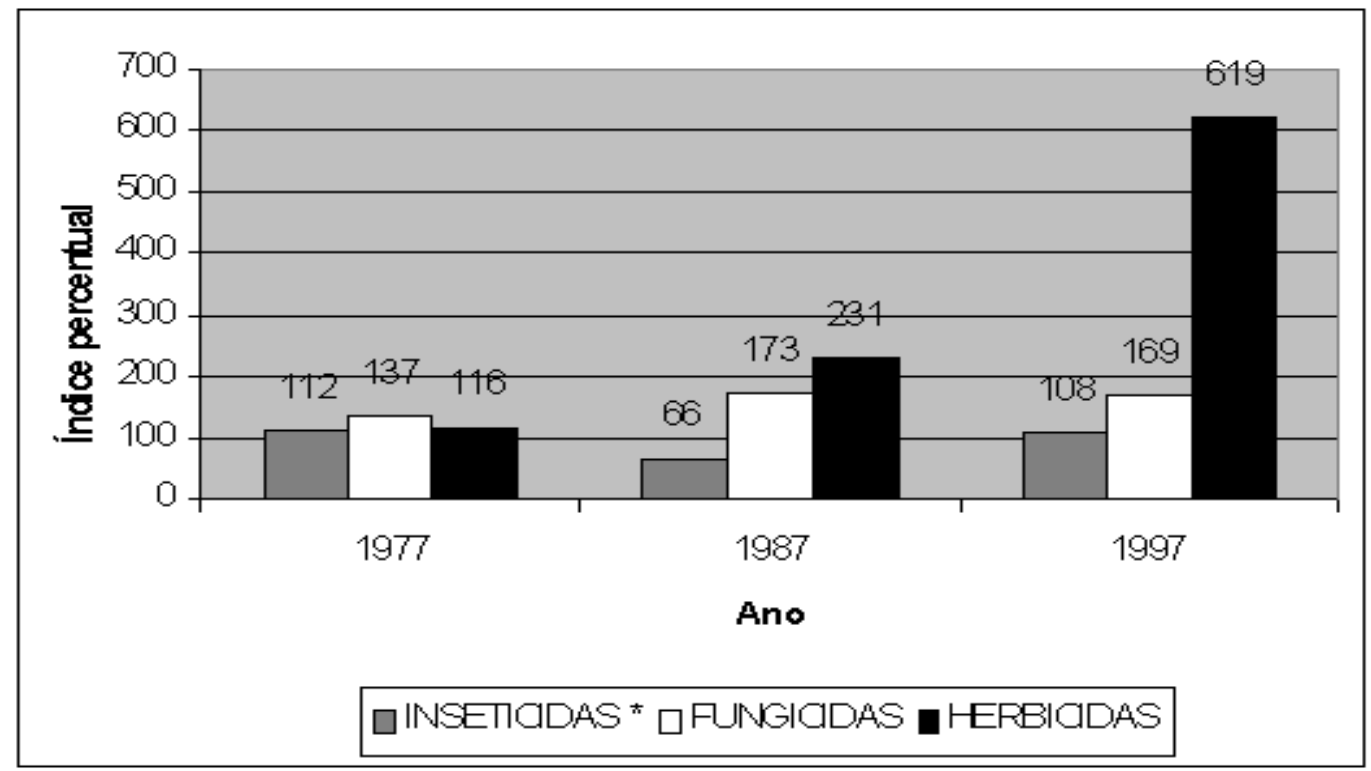

Fonte: elaboração própria, a partir dos dados das tabelas 7 a 10 . 
Tomando-se a cultura da soja, no tocante aos aspectos de produtividade, área plantada, produção, e consumo de herbicidas (valores de vendas e quantidades consumidas), torna-se possível estabelecer um quadro comparativo dos diversos indicadores de desempenho da cultura e o consumo de herbicidas no período entre 1985 e 1998.

Os índices de produtividade cresceram cerca de 31\%; a área plantada aumentou em aproximadamente $28 \%$; a produção elevou-se em cerca de $70 \%$. Já os valores de vendas de herbicidas para a cultura aumentaram em cerca de $290 \%$, e as quantidades de ingredientes ativos utilizados elevaram-se em aproximadamente $272 \%$, no período (Figura 27).

Figura 27 - Evolução dos índices percentuais de produtividade, área plantada, produção, valor de vendas de herbicidas e quantidades de ingredientes ativos de herbicidas utilizados na cultura da soja. Brasil - 1985 e 1998 (ano base 1984=100)

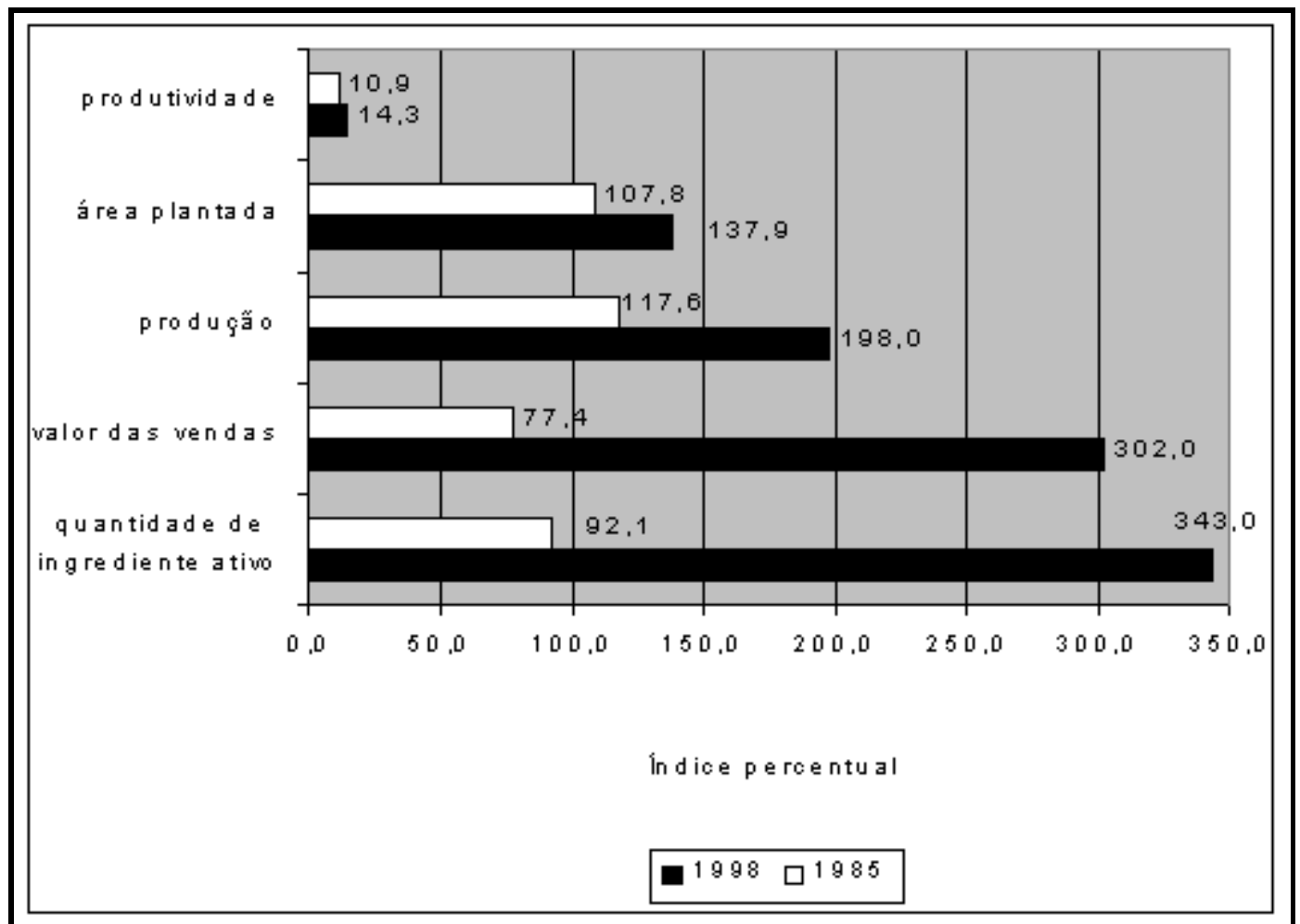

Fonte: elaboração própria, a partir dos dados das tabelas 7 a 10; dados sobre produção e área plantada - Produção Agrícola municipal 1975-1994/IBGE, Departamento de agropecuária. - Rio de Janeiro: IBGE. 
Os dados sobre o comportamento das vendas de agrotóxicos no Brasil, nas últimas décadas, demonstram a intensificação crescente no uso da tecnologia química para o manejo de pragas e doenças nas atividades agropecuárias e florestais.

Os índices de consumo dos agrotóxicos, muitas vezes apresentando comportamento desproporcional em relação aos demais índices de produção, sugerem a ineficácia dos atuais sistemas de controle dos agrotóxicos, dentre os quais se inserem as atividades do receituário agronômico.

Mas as principais constatações da ineficácia do atual sistema de receituário agronômico podem ser feitas através da verificação de seu funcionamento a partir das das instituições que administram o sistema.

Este estudo levantou as condições de funcionamento do receituário agronômico no âmbito dos conselhos profissionais.

Para a realização do levantamento foram enviadas consultas aos CREA's de todos os estados, buscando-se investigar os seguintes pontos:

1 - número de profissionais de engenharia agronômica e florestal atualmente registrados nos conselhos;

2 - número médio de profissionais registrados que atualmente exercem a atividade do receituário agronômico,

3 - dispositivos legais, existentes ao nível do CREA (estado), relativos e ao tema do receituário agronômico;

4 - número médio mensal de receitas (e ART's) recebidas pelo CREA;

5 - tipo de processamento dado às informações das receitas recolhidas; 
6 - tipos de infrações eventualmente constatadas junto a esta atividade;

7 - número médio mensal ou anual de processos de infração relacionados ao receituário.

8 - eventuais parcerias ou intercâmbios realizados com os demais órgãos responsáveis pela fiscalização do uso dos agrotóxicos, nas áreas de agricultura, saúde, meio ambiente e trabalho;

9 - contatos (assistentes e gerentes de fiscalização, e conselheiros envolvidos ) junto a Câmara de Agronomia, para eventuais detalhamentos das informações.

Foram realizadas consultas junto a vinte e seis CREA's, mas somente cinco ofereceram alguns subsídios à consulta formulada (Minas Gerais, Mato Grosso do Sul, Pernambuco, Rio Grande do Sul e São Paulo).

O número de profissionais envolvidos com a atividade do receituário agronômico parece contemplar pequena parcela da categoria habilitada. No estado do Mato Grosso do Sul apenas 150 profissionais, de um total de cerca de 1300, exercem atividades de receituário agronômico. O Estado de São Paulo conta com cerca de 13.000 profissionais habilitados, entretanto em levantamento realizado no ano de 1994 constatou-se que apenas 500 profissionais dedicavam-se a prescrever receitas para uso de agrotóxicos.

Dentre os estados que responderam ao levantamento, todos apontaram a existência de dispositivos legais aprovados pelas Câmaras de Agronomia, buscando-se regular o funcionamento do receituário agronômico. A maioria desses dispositivos estabelece o número máximo de receitas admitidas por profissional, para cada mês de atuação, sendo que os valores variam entre 200 e 300 receitas/mês.

A definição deste parâmetro para o número máximo de receitas emitidas por cada profissional, a cada mês, fixado entre 200 e 300 receitas, já demonstra a visão atribuída 
à prática do receituário agronômico: um mero instrumento burocrático a acompanhar os procedimentos de vendas de agrotóxicos, na tentativa de agregar a possibilidade de caracterização da responsabilidade técnica dessa operação, por meio do recolhimento compulsório das taxas de A.R.T (Anotação de responsabilidade técnica). Isto porque certamente não seria possível imaginar a viabilidade de que um profissional viesse a emitir de 10 a 15 receitas por dia (200 ou 300 receitas a cada 20 dias úteis) atendendo aos preceitos metodológicos preconizados para o receituário agronômico, dentro do conceito de semiotécnica agronômica, proposto por GUERRA (1978).

Em relação ao número médio de receitas recebidas pelos CREA's os valores levantados apresentaram sensível variação. No estado de São Paulo o volume atinge cerca de 38.000 receitas/mês. No Rio Grande do Sul o número médio de receitas emitidas gira em torno de 5000, a cada mês. Já o estado do Mato Grosso do Sul produz uma média de 2500 receitas/mês.

De forma geral, nenhum dos estados que atenderam à consulta referiram estar dando qualquer tratamento às informações das receitas, de forma a explorar seu eventual potencial como indicador a subsidiar estudos sobre o uso de agrotóxicos.

O estado de São Paulo desenvolveu uma experiência de implantação de um banco de dados baseado nas receitas emitidas entre 1993 a 1995, mas o trabalho foi tópico, não consolidando rotina para o tratamento das informações recolhidas.

O CREA-SP e a Embrapa Meio Ambiente (Centro Nacional de Pesquisa de Monitoramento e Avaliação de Impacto Ambiental - CNPMA), estabeleceram um convênio visando utilizar o receituário agronômico como fonte de informação sobre o uso de agrotóxicos. Foi desenvolvido um aplicativo específico para o tratamento dos dados provenientes das receitas, denominado SISCREA (NEVES, et al., 1998).

A partir da alimentação deste sistema é possível gerar vários tipos de relatórios sobre o uso de agrotóxicos, tais como:

- carga total de agrotóxicos; 
- relação de produtos utilizados;

- relação de culturas;

- relação de municípios;

- relação dos produtos mais utilizados para um município;

- relação da quantidade de agrotóxicos utilizada nas culturas, para um município;

- número de receitas emitidas por profissional;

- relação de receitas aplicadas por um determinado profissional.

O trabalho desenvolvido pela Embrapa Meio Ambiente resultou na elaboração de uma ferramenta de análise que extrapola as necessidades iniciais restritas de acompanhamento das receitas apenas sob o aspecto da fiscalização do exercício profissional. O sistema desenvolvido para o tratamento dos dados das receitas pode também ser associado a outras fontes de informações e vir a compor um banco de dados mais completo, capaz de trabalhar o perfil de uso dos agrotóxicos em determinada base geográfica. A utilização da tecnologia dos sistemas de informações geográficas (SIG), pode fazer a integração do banco de dados tabulares com dados geográficos.

A figura 28, a seguir, mostra o esquema geral concebido para o sistema.

Figura 28 - Esquema geral do trabalho de tratamento e aplicação dos dados do receituário agronômico desenvolvido pela Embrapa Meio Ambiente.

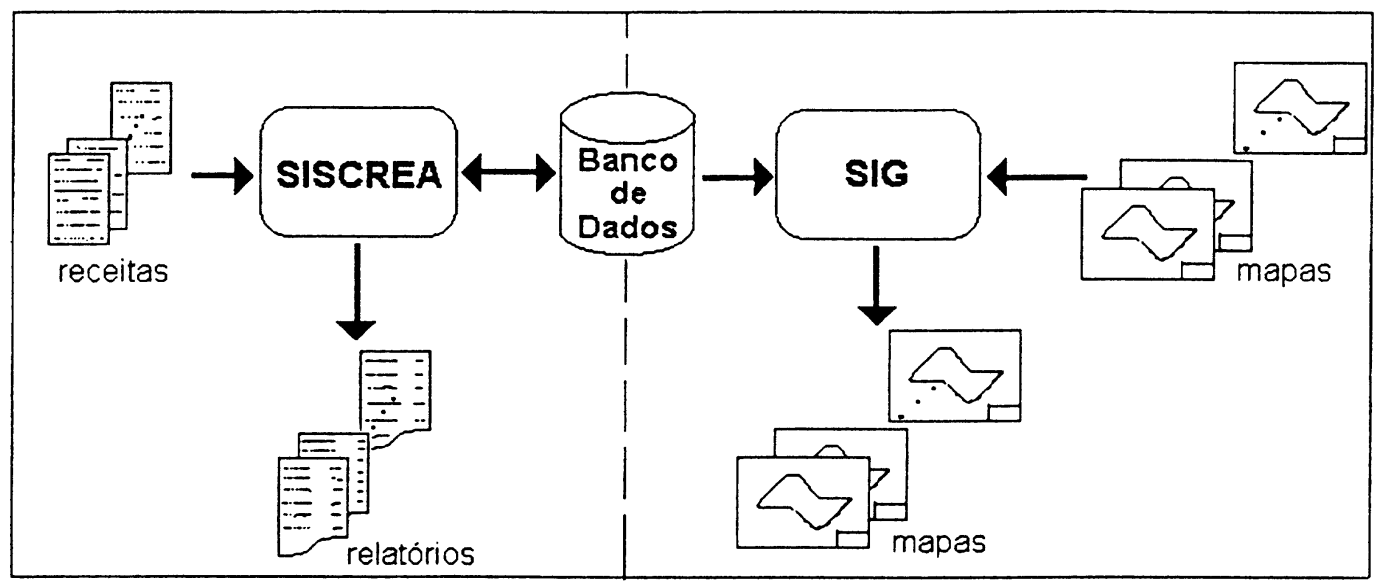

Fonte: NEVES, et al.(1996) 
Mas a utilização deste sistema para análise dos dados dos receituários no estado de São Paulo não teve continuidade. Dificuldades institucionais e restrições de verbas para o financiamento da implantação do sistema no âmbito do CREA, paralizaram a atividade até o presente momento.

A tecnologia desenvolvida pela Embrapa Meio Ambiente poderia ter aplicação expandida para outros âmbitos, como por exemplo, os serviços de defesa sanitária dos diversos estados, os quais são responsáveis pela físcalização do uso de agrotóxicos.

A vocação potencial de utilização do receituário agronômico, como parte de um sistema amplo de informações a compor um quadro sobre a ocorrência das pragas e doenças, a dinâmica populacional, o nível de dano econômico, as regiões de uso mais intenso de agrotóxicos, o estudo epidemiológico das populações expostas, dentre outras possibilidades, já fazia parte das propostas de GUERRA (1991), ao enfatizar a importância de implantação do SIA - Sistema Integrado de Avisos (Figura 29)

Figura 29 - Funcionamento do sistema integrado de avisos (SAI)

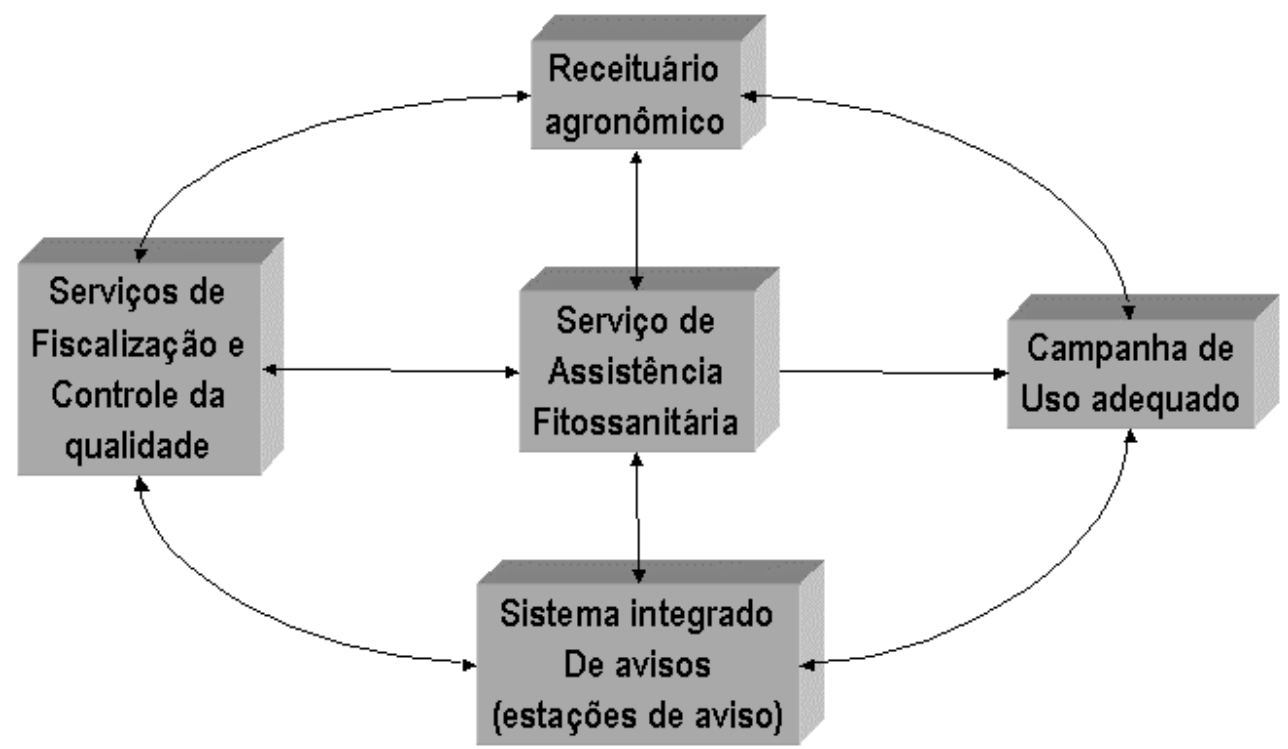

Fonte: extraído de GUERRA, 1991

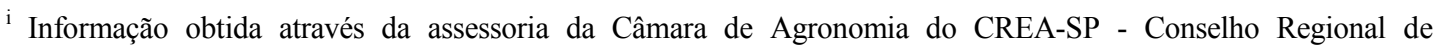
Engenharia, Arquitetura e Agronomia do Estado de São Paulo.
} 
Neste sistema o receituário agronômico seria parte de uma rede maior de recursos e apoios logísticos estruturados de forma a propiciar a produção de informações úteis para os processos de tomada de decisão em relação ao manejo de pragas e doenças nas atividades agrícolas.

Mas nenhuma das experiências levadas a efeito na implantação do receituário agronômico, tanto no âmbito dos serviços de defesa agropecuária, como no sistema CREA, conseguiu dar sustentação aos requisitos da proposta de GUERRA (1991).

Não obstante as evidentes distorções identificadas no exercício do receituário agronômico aos moldes atuais, parece bastante tímida a atuação físcal sobre os aspectos relacionados ao exercício profissional ligado ao receituário agronômico.

No levantamento efetuado junto aos CREA's somente o conselho do estado do Mato Grosso do Sul respondeu a respeito da questão relativa ao número médio de processos de infração relacionados ao receituário agronômico. $\mathrm{O}$ número médio apontado para as ocorrências limita-se a dois processos por ano, envolvendo profissionais e 10 processos por ano, nos casos relativos a empresas.

Em geral as parcerias verificadas para as eventuais ações conjuntas de fiscalização ficam limitadas a iniciativas voluntariosas, uma vez que em nenhum caso se constatou a existência de convênios ou outros instrumentos formais de ação conjunta.

Os principais problemas encontrados na implantação e prática do receituário agronômico, no âmbito dos conselhos profissionais, foram bem detalhados nas informações oferecidas pelo CREA-MG, a saber:

- $\quad$ excesso de receitas para um mesmo profissional ("agrônomo de balcão");

- numeração incorretas em receitas informatizadas;

- mistura de recomendações para culturas diferentes, na mesma receita (não permitido por lei);

- ausência de assinatura do profissional responsável e do usuário; 
- ausência do recolhimento das ART's (anotação de responsabilidade técnica);

- falta de comprovante do pagamento das ART's;

- pouco envolvimento dos produtores rurais;

- poucos profissionais autônomos e extensionistas prescrevendo receitas;

- desinteresse dos comerciantes em custear visitas do profissional ao campo;

- custo elevado para manutenção da atividade (custo do bloco de receitas ou dos "softwares" utilizados, custo da ART, custo dos honorários do profissional responsável técnico, etc)

- falta de estrutura dos órgãos públicos para fiscalização eficiente, principalmente no campo;

- excesso de informações a constar das receitas, por exigência da legislação, levando a uma simples "cópia das bulas";

- formação deficiente dos profissionais, os quais demonstram insegurança diante das responsabilidades assumidas na atividade;

As informações apresentadas no $\mathrm{V}$ Congresso Nacional de Agrotóxicos e Receituário Agronômico (CNARA), realizado na cidade do Rio de Janeiro, em agosto de 2000, dão conta de que praticamente nenhum dos conselhos profissionais nos estados mantém cadastro das informações recolhidas das receitas. A única exceção ocorre no estado do Rio Grande do Sul, onde existe um esforço na composição de um banco de dados baseados nas receitas emitidas, mas esta iniciativa é ainda incipiente e não abrangem uma análise completa das informações potencialmente existentes.

De forma geral não há tabulação, tratamento estatístico ou qualquer outro estudo desenvolvido com base nas receitas que chegam até os órgãos do sistema CONFEA/CREA.

Um outro ponto de averiguação sobre o aproveitamento das informações constantes nas receitas agronômicas, diz respeito aos órgãos de defesa vegetal responsáveis pela fiscalização do uso dos agrotóxicos. 
As secretarias de agricultura dos governos estaduais deveriam, por atribuição legal, estar desenvolvendo ações de fiscalização do uso dos agrotóxicos, e neste contexto a fiscalização do receituário agronômico deveria compor o ponto de partida.

Entretanto, com exceção do serviço de fiscalização do Estado do Paraná, nenhum outro estado conta atualmente com qualquer rotina de acompanhamento das receitas emitidas através do sistema de receituário agronômico.

Em artigo divulgado no V Congresso Nacional de Agrotóxicos e Receituário Agronômico, o engenheiro Reinaldo Skalisz, responsável pelo serviço de fiscalização da Secretaria de Agricultura do Estado do Paraná, relaciona os principais problemas detectados durante as atividades de fiscalização do receituário agronômico, e que deram origem a autação e penalização dos envolvidos:

- prescrição de produto formulado em pastilhas (gastoxin) para uso no controle de pragas em armazenamento de cereais, através de "pulverização";

- prescrição de produtos granulados, para uso direto no solo, tais como Temik, Furadan 50 G e Granutox, receitados para aplicação por "pulverização";

- recomendação de uso de agrotóxicos em culturas inexistentes nas propriedades;

- receitas impressas por computador, emitidas por leigos e levando apenas a assinatura do profissional;

- receitas assinadas "em branco" por profissionais, para posterior preenchimento por leigos (geralmente o balconista da loja);

- receitas prescritas no Paraná, para uso de agrotóxicos em estabelecimentos rurais localizados nos estados do Amapá, Rondônia, Pará, Mato Grosso, Minas Gerais, São Paulo, Santa Catarina, Rio de Janeiro e Rio Grande do Sul;

- receitas prescritas depois de concretizadas as vendas dos produtos;

- receitas prescritas para áreas superiores às existentes nas propriedades;

- receitas com indicação errada do prazo de carência do produto prescrito;

- receitas para vendas antecipadas, para agricultores que estariam plantando em data futura, dois ou três meses após a compra dos agrotóxicos;

- prescrição de até 1500 receitas no intervalo de cinco dias. 
SKALISZ (2000) observa: "Como vemos a classe agronômica não assumiu de fato o receituário agronômico, não está preparada para desenvolver esta atividade, não está levando a sério e com isso quem está perdendo é nossa classe e a sociedade".

Outro fato que constata a distorção sofrida no processo de implantação e operacionalização do receituário agronômico, a partir de sua proposta inicial, é a verificação de que até mesmo via internet é possível se fazer a compra de agrotóxicos "a priori", sem a necessidade de uma efetiva avaliação técnica a justificar o ato de comercialização.

Algumas empresas promotoras do comércio eletrônico já disponibilizam o acesso a esquemas de comercialização onde o usuário, após detalhadas pesquisas sobre possibilidades e preços dos produtos, pode requisitar a compra e entrega dos produtos, em operações feitas diretamente na rede de computadores ligados à internet. (Figura 30) 
Figura 30 - Exemplos de páginas na internet disponibilizando a compra de agrotóxicos através do comércio eletrônico.

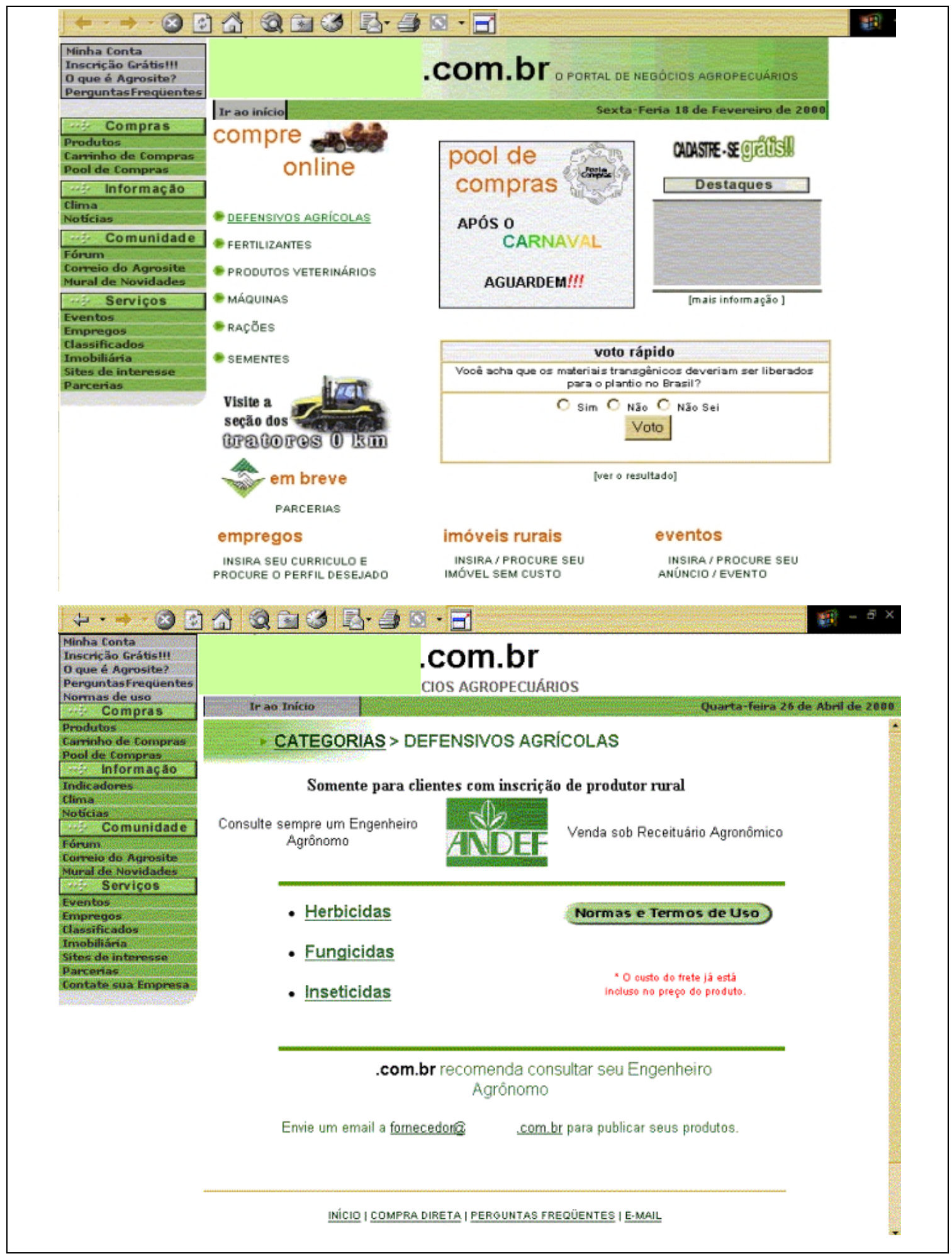

Fonte: http://www.agrosite.com.br, acesso em 18 de fevereiro e 20 de abril de 2000. 
A ineficácia do receituário agronômico como instrumento de orientação técnica também pode ser avaliado a partir de levantamento realizado pela FUNDACENTRO, em parceria com a Secretaria de Agricultura e Abastecimento do Estado de São Paulo. Através de convênio firmado, para atuação conjunto entre os anos de 1997 e 2000, foram realizadas várias atividades envolvendo a questão do uso de agrotóxicos, e dentre tais ações, realizou-se um levantamento de campo para o diagnóstico da situação de uso dos agrotóxicos em São Paulo.

O diagnóstico efetuado teve como objetivo identificar os seguintes aspectos relativos ao uso de agrotóxicos no estado: o contexto da tomada de decisão em relação ao uso, o acesso a orientação técnica na recomendação, o acesso à orientação técnica na aplicação, o descarte de embalagens, os procedimentos frente à intoxicações, o cumprimento do período de carência, os produtos químicos mais utilizados, dentre outros.

A metodologia utilizada baseou-se em entrevistas junto aos produtores e aplicadores, a partir de uma amostra de cerca de 3000 estabelecimentos rurais, em 100 municípios do estado, visitados durante o mês de julho de 1997.

As entrevistas de campo foram realizadas por estudantes de agronomia das universidades públicas do estado: Unesp (Ilha Solteira, Jaboticabal e Botucatu) e USP (Piracicaba), com supervisão dos técnicos do serviço de extensão rural e da equipe técnica de coordenação da pesquisa.

Para o estabelecimento da amostra foram utilizados os dados do cadastro de imóveis rurais da receita federal (ano 1993), em ação desenvolvida com apoio do Instituto de Economia Agrícola (IEA).

Os critérios de escolha dos municípios basearam-se em dois pontos de análise:

1. municípios com maior número de unidades de produção desenvolvendo culturas com emprego mais intenso de agrotóxicos; 
2. municípios com maior número de unidades de produção que atendiam aos critérios estabelecidos pelo Programa Nacional de Fortalecimento da Agricultura Familiar (PRONAF);

A seleção das principais culturas consumidoras de agrotóxicos levou-se em conta os dados fornecidos pela Seção de Resíduos do Instituto Biológico de São Paulo e informações fornecidas pelo órgão de assistência técnica e extensão rural do estado a CATI - Coordenadoria de Assistência Técnica Integral.

Os dados coletados visavam fornecer subsídios para o diagnóstico dos vários aspectos ligados ao uso de agrotóxicos, tais como: perfil do aplicador, origem da assistência técnica, uso do receituário agronômico, conhecimento sobre informações dos rótulos dos produtos, nível de utilização dos EPI's, cuidados gerais, medidas de segurança nas diversas etapas do uso, treinamentos realizados, cuidados após a aplicação, equipamentos de aplicação utilizados, etc. Tais dados foram reunidos em um banco de informações, com acesso disponibilizado pelas instituições promotoras do estudo (FUNDACENTRO E IEA-SP), e serviram de suporte para algumas análises já publicadas (VICENTE et al.,1998; RAMOS, et al., 1999).

Outras informações coletadas, referentes aos aspectos ligados ao receituário agronômico, são apresentadas e discutidas ,a seguir.

Dentre os 3000 entrevistados, cerca de 48,9\% referiram não receber qualquer tipo de assistência técnica para o desenvolvimento de atividades ligadas ao manejo fitossanitário.

Em relação à recomendação dos agrotóxicos, apenas $49 \%$ dos entrevistados apontaram o engenheiro agrônomo como o responsável pela indicação do uso da tecnologia química em suas unidades de produção. A origem dos técnicos que fazem a recomendação de uso nestes estabelecimentos é a seguinte: $18,5 \%$ são técnicos de cooperativas; $25,7 \%$ são oriundos das revendas de agrotóxicos; $8,3 \%$ são técnicos 
consultores particulares; e apenas $6,3 \%$ são oriundos dos serviços oficiais de extensão rural.

Em relação aos locais de compra dos agrotóxicos, cerca de 30\% dos entrevistados referiram as cooperativas como principal base para a aquisição dos produtos; $52 \%$ compram em lojas de insumos agropecuários, e apenas $2 \%$ compram direto com vendedores que visitam as propriedades.

Dentre os produtores que compram em lojas de insumos apenas 55\% apontam o engenheiro agrônomo como responsável pela recomendação de uso dos agrotóxicos, informação esta que sugere a existência de grande número de vendas realizadas sem a particpação da intermediação técnica prevista na lógica do receituário agronômico .

Para os que compram diretamente nas cooperativas o percentual de particpação do engenheiro agrônomo na recomendação de uso dos agrotóxicos parece ser mais efetiva, tendo em vista que cerca de $72 \%$ dos entrevistados referiram receber recomendação técnica por profissional habilitado. Entretando a investigação não avaliou a qualidade ou o tipo de recomendação técnica oferecida.

A investigação sobre o efeito do receituário agronômico como fonte de orientação ao aplicador de agrotóxicos demonstrou que apenas $34 \%$ dos entrevistados referiram utilizar o receituário agronômico com referência para o manejo da tecnologia química.

Os dados preliminares deste diagnóstico demonstram a tímida participação da sistemática de receituário agronômico implantada no estado de São Paulo, na lógica e prática de uso da tecnologia dos agrotóxicos nas atividades de manejo fitossanitário.

A situação diagnosticada em São Paulo, estado responsável pelo maior volume de receitas emitadas no país, pode surgerir o comportamento e a eficácia do receituário nas outras regiões onde ainda se busca implantar esta prática de controle. 


\section{CONCLUSÃO: QUEBRANDO O FEITIÇO E BUSCANDO A RECEITA DO ANTÍDOTO}

A luta pelo controle do uso dos agrotóxicos no Brasil teve início ao final da década de 70, a partir da mobilização de ampla parcela da comunidade técnica ligada ao setor agrícola e de ambientalistas sensíveis aos problemas decorrentes do uso da tecnologia química no combate às pragas e doenças no campo.

Dentre os vários mecanismos sugeridos à época, para se tentar minimizar o processo de disseminação indiscriminada dos agrotóxicos, a proposta de implantação do sistema de receituário agronômico mereceu a atenção especial da comunidade agronômica.

A idéia baseava-se na implementação de um sistemática que possibilitasse a presença da perícia técnica a intermediar o acesso do usuário final à tecnologia de risco, representada pelos produtos químicos.

O contexto das primeiras experiências de adoção do receituário agronômico esteve inserido em um ambiente de grande controvérsia sobre as políticas oficiais de incentivo ao uso de agrotóxicos, desenvolvidas a partir de mecanismos de estímulo às vendas subsidiadas pelo crédito rural, associadas aos mais variados esforços que visavam a consolidação das políticas de modernização da agricultura, baseadas no modelo da chamada "revolução verde". 
A luta pela implantação do receituário agronômico ganha conotação política e amplia-se no âmbito da comunidade agronômica, das organizações ambientalistas e das organizações voltadas à defesa dos interesses dos consumidores.

O ambiente institucional vivido pelos grupos de engenheiros agrônomos e ambientalistas ligados à luta pela implantação do receituário agronômico não se mostrava muito favorável aos movimentos populares e democráticos. E neste contexto o receituário agronômico, além de se constituir como uma opção viável para minimizar os abusos detectados pelo uso indiscriminado dos agrotóxicos (a exemplo das experiências bem sucedidas, realizadas em alguns municípios do Rio Grande do Sul), também servia como bandeira de ação e mobilização para os movimentos que lutavam em favor dos avanços democráticos e de participação popular, inclusive no desenho das políticas agrícolas e agrárias praticadas no país.

Com o amadurecimento dos debates em torno do receituário agronômico foi detectada a oportunidade de agregar conteúdo técnico mais consistente ao sistema de controle dos agrotóxicos, e neste sentido foi concebida uma doutrina metodológica que conferia ao receituário agronômico um caráter muito mais abrangentes do que propriamente a definição de um simples mecanismo de controle de vendas dos agrotóxicos.

Desta forma a difusão do instrumento do receituário agronômico ganha força na comunidade agronômica, ao mesmo tempo em que encontra fortes resistências dos diversos atores interessados na manutenção dos padrões de comércio dos produtos químicos na agricutura.

A luta pela regulamentação e controle dos agrotóxicos no Brasil percorre vários desafios durante a década de 80 , até a consolidação do primeiro instrumento legal mais abrangente representado pela chamada "Lei dos Agrotóxicos", aprovada em 1989. A implantação do receituário agronômico também acompanhou esta trajetória, e neste caminho, construído pelos diversos atores da rede sócio-técnica envolvida, a proposta 
inicial foi sofrendo alterações em seu conteúdo e forma, com as conseqüentes reações por parte de seus defensores e opositores.

A indústria de agrotóxicos, e seus representantes, fizeram forte oposição às tentativas iniciais de implantação da sistemática do receituário agronômico. Mas no decorrer do longo período de discussões legais e de dificuldades de operacionalização da idéia, tal resistência foi se mostrando menos presente.

A situação atual constatada é de que, apesar de se ter a institucionalização do receituário agronômico, por imposição legal, a prática de sua implantação e operacionalização não se mostra efetiva.

Tal inocuidade modifica o comportamento dos atores envolvidos na questão dos agrotóxicos, de forma a praticamente reverter o quadro de opiniões. Os que no passado eram contra, hoje colaboram na divulgação da necessidade legal de existência da receita para a compra de agrotóxicos. Por outro lado, muitos dos que lutaram pela implantação do receituário agronômico, ao início de sua adoção, hoje se mostram pelo menos céticos quanto ao seu efetivo papel.

A distorção dos princípios e conceitos iniciais do receituário agronômico, ocorrida ao longo de seu processo de implantação e operacionalização, ficou evidenciada a partir da demonstração de que praticamente todos os passos metodológicos e requisitos logísticos preconizados por GUERRA (1978) e GUERRA \& SAMPAIO (1991), foram desconsiderados no estabelecimento das rotinas de operação e prática do instrumento.

A ênfase atribuída ao receituário agronômico no âmbito dos sistemas de fiscalização do exercício profissional e de defesa sanitária vegetal, ficou limitada aos aspectos burocráticos do instrumento, perdendo conexão com os princípios emancipadores colocados pelos precursores da idéia inicial, no sentido de contribuir efetivamente para o controle do uso indiscriminado dos agrotóxicos. 
O modelo de intermediação técnica proposto pelo instrumento do receituário agronômico, a partir de modelo inspirado nas relações do tipo "médico-pacientemedicamento", não se mostrou aplicável ao contexto da atividade agronômica. A inexistência de pressupostos relacionados à cultura ética profissional e a aspectos estruturais consistentes a permear a relação entre os produtores rurais e os atores responsáveis pela assistência técnica e a extensão rural, no contexto de aplicação da prática do receituário, ao longo de seu período de implantação, indicam a impropriedade de aplicação, por via legislativa, de dispositivo que viesse a garantir a validação de uma relação de necessidade, acesso e confiança entre os técnicos e produtores, para o enfrentamento dos problemas decorrentes do manejo de pragas e doenças nas atividades agropecuárias e florestais.

As teorias nas quais o presente trabalho se baseia sustentam a idéia de que os objetos, os artefatos e os processos, não são entidades neutras nas relações sociais; seus significados variam de acordo com as redes das quais fazem parte.

A rede sócio-técnica que deu início às primeiras experiências de implantação do receituário atribuiu um significado de renovação e avanço na adoção de práticas emancipadoras para se fazer frente aos problemas de manejo das pragas e doenças nas atividades agropecuárias e florestais, e também para o enfrentamento do uso indiscriminado de agrotóxicos.

No decorrer do processo de discussão e implantação da proposta de receituário agronômico a rede vai mudando, os atores, os interesses e as relações de força acompanham esse movimento. Desta forma, novos significados vão sendo atribuídos ao receituário, agora muito mais identificado como um instrumento inócuo de controle de vendas, bem distante dos princípios iniciais que inspiraram sua implantação.

O receituário agronômico, nos atuais moldes em que vem sendo praticado, somente pode interessar aos setores de produção e comercialização dos agrotóxicos, tendo em vista que sua manutenção representa na prática a abolição dos sistemas de controle.

Também são atores relevantes na manutenção do atual sistema de receituário agronômico as parcelas da corporação agronômica que ajudaram a atribuir, ao longo 
do tempo, um caráter burocrático e distorcido ao instrumento. Tais atores estariam de certa forma se beneficiando desses aspectos burocráticos ou ainda do mito de estarem contribuindo para um sistema que já se mostrou inócuo como sistema de controle e inadequado ou irreal como doutrina técnica desprovida de seu contexto institucional básico para sua efetividade.

O aperfeiçoamento dos sistemas de controle do uso indiscriminado de agrotóxicos no Brasil ainda permanece como ponto relevante da agenda ambiental e de saúde pública e somente as ações diversificadas e multisetorias poderão dar conta de reverter o atual quadro. Tais ações devem estar direcionadas para o aperfeiçoamento das seguintes estratégias:

- aperfeiçoamento dos sistemas de registro dos agrotóxicos, incluindo a adoção efetiva de caracterização de produtos definidos como de venda restrita por aplicador certificado;

- melhoria da infraestrutura laboratorial e de apoio às análises de resíduos;

- capacitação de profissionais das áreas agronômicas e de saúde;

- capacitação e habilitação dos usuários;

- aperfeiçomento dos sistemas de bulas e rotulagens dos produtos;

- direcionamento da propaganda comercial voltada exclusivamente aos responsáveis pela prescrição dos agrotóxicos;

- aprimoramento da legislação relativa a segurança e saúde do trabalhador rural;

- implantação de sistemas efetivos de destinação final adequada para embalagens e sobras de produtos; 
- incremento da pesquisa e extensão de técnicas de controle de pragas;

- ampliação dos programas de manejo integrado de pragas;

- estabelecimento de políticas de subsídios e incentivos creditícios aos produtores dedicados a práticas de controle de pragas e doenças que prescindem do uso de agrotóxicos, e de práticas agrícolas de baixo impacto ambiental;

- estudo e implantação de mecanismos de taxação dos produtos mais tóxicos, de forma a desencorajar o uso desnecessário.

Algumas destas iniciativas já estão presentes no cenário atual de manejo dos riscos relacionados aos agrotóxicos no Brasil. Mas certamente todas necessitam ser incrementadas e ampliadas. 


\section{REFERÊNCIAS BIBLIOGRÁFICAS}

ABRAMOVAY, Ricardo (1999) " O tortuoso caminho da sustentabilidade: tendências recentes da agricultura na região Sul ", Agenda 21 Brasileira - Área temática: Agricultura Sustentável, Consórcio Museu Emílio Goeldi - Documento de Trabalho, 42 p. (mimeo).

ACIRRADOS OS DEBATES com a nova legislação federal. Dirigente Rural. São Paulo, :20-25, dezembro, 1984.

AGROTIS. "Sistema de Receituário Agronômico." [programa de computador]. Versão 4.0 . Curitiba: Agrotis, atualizações: agosto de 1996 a 2000.

AGROTÓXICOS deverão ter receituário. Folha de São Paulo. São Paulo, 26 junho 1984.

AS DISTORÇÕES em torno de um insumo decisivo. AGRICULTURA DE HOJE São Paulo, 60(5):44-47, junho, 1980

ASSOCIAÇÃO NACIONAL DE DEFESA VEGETAL - ANDEF. (2000) "Comportamento do mercado de produtos fitossanitários" ANDEF. 4 p. [on line]. Consultado via http://www.andef.com.br/merctex2.htm, em 25.08.2000.

BARZOTTO, Valdir Heitor. (1992) "Leitura de propaganda de agrotóxicos: contribuição aos estudos da ideologia da modernização". Campinas. 1992.96 p. [Dissertação de mestrado - Instituto de Estudos da Linguagem. UNICAMP]

BIJKER, W.E.; HUGHES, T.P. \& PINCH, T.F. (1989) The Social Construction of Technological Systems - New Directions in the Sociology and History of Technology, Massachusetts: MIT Press, 405 p..

BIJKER, W.E. \& LAW, J. (1992) Shaping Technology/Building Society - Studies in Sociotechnical Change. Massachussetts: MIT Press, 341 p.. 
BRASIL. Decreto No 98.816, de 11 de janeiro de 1990. Regulamenta a Lei 7.802, de 11 de julho de 1989, que dispõe sobre a pesquisa, a produção, a embalagem e rotulagem, o transporte, o armazenamento, a comercialização, a propaganda comercial, a utilização, a importação, a exportação, o destino final dos resíduos e embalagens, o registro, a classificação, o controle, a inspeção e a fiscalização de agrotóxicos, seus componentes e afins, e dá outras providências. Diário Oficial da União. Brasília, 12 jan. 1990. p. 876-888.

BRASIL. Lei No 7802, de 11 de julho de 1989. Dispõe sobre a produção, a embalagem e rotulagem, o transporte, o armazenamento, a comercialização, a propaganda comercial, a utilização, a importação, a exportação, o destino final dos resíduos e embalagens, o registro, a classificação, o controle, a inspeção e a fiscalização de agrotóxicos, seus componentes e afins, e dá outras providências. Diário Oficial da União. Brasília, 12 de julho de 1989. p.p. 11459-11460.

BURTON, D. K. \& PHILOGEN, T. J. R. (1988) "An Overview of Pesticide Usage in Latin America." Rept. of a Contr. N $N^{\circ}$ 0ST85-00181 of the Canadian Wildlife Service, Latin American Program, University of Ottawa. In: PAN AMERICAN HEALTH ORGANIZATION (1993) Pesticides and health in the Americas. Environmental Series n ${ }^{\circ} 12$. Washington, D.C. PAHO, 109 p..

CALLON, Michel (1989) " Society in the Making: The Study of Technology as a Tool for Sociological Analysis ". In: BIJKER, W.E.; HUGHES, T.P. \& PINCH, T.F. The Social Construction of Technological Systems - New Directions in the Sociology and History of Technology, Massachusetts: MIT Press, p.p. 83-103.

CARSON, Rachel (1962) Silent Spring. Boston, Houghton Miffin

CASIDA, J. E., \& QUISTAD, G.B. (1998) "Golden age of inseticide research; past present or future?" Annu. Rev. Entomol. 43:1-16, apud NRC (National Research Council). (2000) The future role of pesticides in US agriculture. Washington, D.C.: National Academy Press. 258 p. [on line] Disponível em http://www.nap.edu/books/0309065267/html/

CASTELLS, Manuel (1999) A sociedade em rede - (A era da informação: economia, sociedade e cultura; v. 1) São Paulo: Paz e Terra, 1999. 617 p..

CHÉRCOLES, Diego Moñux (1999) " Tecnología para el Desarrollo : Hácia uma comprensión de las relaciones entre tecnología, sociedad y desarrollo ". [online]Disponível na Internet via WWW URL: http://www.oei.org.co/cts/monux Arquivo capturado em 20 de setembro de 1999

COLLINS, H. M. (1981) " An empirical relativist programme in the sociology of scientific knowledge". In: Knorr-Cetina y Mulkay, Compils., pp. 85-113.

COMO RECEITAR. Atualidades Agropecuárias. São Paulo, [S.N.]:21, abril, 1980. 
CONGRESSO NACIONAL DE AGROTÓXICOS E RECEITUÁRIO AGRONÔMICO, 4., Goiânia. 1998. Anais. Goiânia, CREA.

CRESCE A DEMANDA por receituário. Dirigente Rural. São Paulo, 29(10):27, outubro, 1990.

DEFENSIVOS AGRÍCOLAS: um programa acelerado. Dirigente Rural. São Paulo, 16(11-12):21-28, nov./dez., 1977.

DEFENSIVO REQUER cautela. Dirigente Rural. São Paulo, 13(8-9):22-27, outubro/ novembro, 1974.

DEPUTADO revela a lei federal para os agrotóxicos. Folha de São Paulo. São Paulo: Geral, 30 de junho, 1984, p.21.

EDUCAR ou proibir. Atualidades Agropecuárias. São Paulo, [S.N.]:16-19, abril, 1980.

EDWARDS, Clive A. (1993) "The impact of Pesticides on the Environment". In: PIMENTEL, D. \& LEHMAN, H. eds. The Pesticide Question - environment, economics, and ethics. New York. Chapman \& Hall, Inc., 1993. pp. 13-46

EMATER-RS "Carta circular n COPER/38-83". Porto Alegre, 06 de setembro, 1983.

ENFIM, UMA LEI para controlar o uso de agrotóxicos. Dirigente Rural. São Paulo, 29(6/7):10-13, junho/julho, 1990.

EPA (US Environmental Protection Agency) (1998) Status of Pesticides in Registration, Reregistration, and Special Review (Rainbow Report). Washington, D.C.: EPA, Office of Pesticide Program. 462 p. [on line] Disponível em http://www.epa.gov/oppsrrd1/Rainbow/98rainbo.pdf

ESTADO de São Paulo lança seu receituário agronômico. Folha de São Paulo. São Paulo: Folha Agropecuária, 7 setembro, 1985, p.13.

ESTADOS criticam projeto que regulamenta agrotóxicos. Folha de São Paulo. São Paulo, 31 de julho, 1984, p.15.

EXCESSO de defensivos desequilibra ecologia. Química e Derivados. São Paulo, [S.N.]:12, julho, 1979.

FOOD AND AGRICULTURE ORGANIZATION OF THE UNITED NATIONS (FAO) (1995) World Agriculture Towards 2010 - An Fao Study. Chichester, ed. Nikos Alexandratos, 488 p..

FERRARI, Antenor. (1985) Agrotóxicos: a praga da dominação. Porto Alegre, Mercado Aberto, 88 p.. 
FERREIRA, Célia R. R. P. T. et alii. (1986) " Evolução do setor de defensivos agrícolas no Brasil, 1964-83 ". Instituto de Economia Agrícola - Relatório de Pesquisa $n^{\circ}$ 2/86, São Paulo: 1986, 51p..

FERREIRA, Célia Regina P. T. (1999) " Defensivos agrícolas". Informações Econômicas. São Paulo, 29(9):43-45, setembro.

FUTINO, Ana Maria e SILVEIRA, José Maria J.F. (1991) " A indústria de defensivos agrícolas no Brasil ". Agricultura em São Paulo. São Paulo, 38(T.Esp.):1-43.

GALVÃO, D. M. (1977/1978) Catálogo dos defensivos agrícolas. Ministério da Agricultura, $1^{\circ}$ suplemento, $134 \mathrm{p} .$. $2^{\circ}$ suplemento, 94 p..

(1979) Catálogo dos defensivos agrícolas. Ministério da Agricultura,

(1980) Catálogo dos defensivos agrícolas. Ministério da Agricultura, $3^{\circ}$ suplemento, $174 \mathrm{p} .$.

GALVÃO, D.M. \& PIRES, E. A. (1980) Catálogo dos defensivos agrícolas. Ministério da Agricultura, 427 p..

GALVÃO, D. M. \& BARTOCCI, F. X. S. (1981) Catálogo dos defensivos agrícolas. Ministério da Agricultura, $4^{\circ}$ suplemento, 125 p..

GARCIA, E. G. (1996) "Segurança e saúde no trabalho rural com agrotóxicos: contribuição para uma abordagem mais abrangente". São Paulo. 1996. 211 p. [Dissertação de mestrado - Faculdade de Saúde Pública. USP]

GELMINI, G. .A. (1990) Agrotóxicos: Legislação - Receituário Agronômico. Campinas: Coordenadoria de Assistência Técnica Integral - CATI. 103 p. $22 \mathrm{~cm}$ (Manual, 29)

GUERRA, Milton de Souza (1978) "Análise conceitual do receituário agronômico." In: UNIVERSIDADE FEDERAL DE PELOTAS. $11^{\circ}$ Curso sobre Fundamentos do Receituário Agronômico. Pelotas. Centro de Treinamento e Informação do Sul (CETREISUL), 1978 (apostila)

GUERRA, Milton de Souza (1982) " Receituário agronômico: implantação e operacionalização". In: Francisco GRAZIANO NETO. coord. Uso de agrotóxicos e Receituário Agronômico. São Paulo: Agroedições, p.p.171-179.

GUERRA, M. S. \& SAMPAIO, D.P. A. (1991) Receituário Agronômico. São Paulo: Editora Globo. 436 p.

GRAZIANO NETO (org.) (1982) et alii. Uso de agrotóxicos e Receituário Agronômico. São Paulo: Agroedições, 194 p. 
HUGHES, T.P. (1989) " The Evolution of Large Technological Systems ". In: BIJKER, W.E.; HUGHES, T.P. \& PINCH, T.F. The Social Construction of Technological Systems - New Directions in the Sociology and History of Technology, Massachusetts: MIT Press, p.p. 51-82.

IBGE (1997) Produção Agrícola Municipal 1975-1994. /IBGE, Departamento de Agropecuária - Rio de Janeiro: IBGE, 1997

(1998) Censo Agrogpecuário 1995-1996. Rio de Janeiro

INSTITUTO DE ECONOMIA AGRÍCOLA - IEA. (1999) "Defensivos agrícolas". IEA - Secretaria de Agricultura e Abastecimento do Estado de São Paulo. 4 p. [on line] Consultado via http://www.iea.sp.gov.br/defens98.htm em 02.12.1998.

KNORR-CETINA, K. (1983) "The ethnographic study of scientific work: towards a construtivist interpretation of science". In: KNOOR-CETINA, K. \& MULKAY, M. Science observed. Sage. Beverly Hills, Londres, Nueva Delhi, p.p. 115-140.

KUHN, Thomas Samuel (1997) A estrutura das revoluções científicas. Trad. Beatriz Vianna Boeira e Nelson Boeira. 5. ed. São Paulo: Perspectiva, 257 p. (Coleção Debates, 115).

LATOUR, Bruno \& WOOLGAR, Steve (1979) Laboratory Life. Sage, Beverly Hills.

LATOUR, Bruno (1994) A profissão de pesquisador - olhar de um antropólogo. Conferência-debate no Instituto Nacional da Pesquisa Agronômica - Paris, 1994. $36 \mathrm{p}$.

LATOUR, Bruno e WOOLGAR, Steve (1997) A vida de laboratório: a produção dos fatos científicos. Rio de Janeiro. Relume Dumará, 310 p..

LAW, John (1986) "Laboratories and Texts". In: CALLON, M.ichel ; LAW, J. \& RIP, Arie eds. Mapping the Dynamics of Science and Technology: Sociology of Science in the Real Word. Londres, MacMillan, p.p. 35 - 50.

LEGISLAÇÃO sobre defensivos, um assunto controvertido. Dirigente Rural. São Paulo, 23(3):21-31, março, 1984.

LEI FEDERAL SOBRE os agrotóxicos repercute bem. Dirigente Rural. São Paulo, 28(9):16-21, setembro, 1989.

LIMA, Armando David Ferreira (1960) Seis anos na Direção da Defesa Sanitária Vegetal. Rio de Janeiro, GB(Brazil), 1960. 118 p. 
LUTZEMBERGER, José (1982) "A mafia dos pesticides". In: Francisco GRAZIANO NETO. coord. Uso de agrotóxicos e Receituário Agronômico. São Paulo. Agroedições, p.p.187-194.

(1992) Do pomar ao poder. Porto Alegre: L\&PM, 192 p..

MAIS BOM SENSO e menos emoção. Defesa Vegetal. São Paulo, I(5):3, novembro/dezembro, 1984.

McCONNELL, R.; HENAO, S. ; NIETO, O.; ROSENSTOCK, L.; TRAPÉ, A.Z.; WESSELING, C. (1993) " Pesticides ". In: FINKELMAN, J.; COREY, G.; CALDERON, R. eds. Environmental epidemiology: a project for Latin America and the Caribbean. México. Pan American Center for Human Ecology and Health - ECO, p.p. 147-201.

MERTON, Robert K. (1937) " A ciência e a ordem social ". In: MERTON, R. K. Sociologia - Teoria e Estrutura. São Paulo: Mestre Jou ed., 1970. 753 p..

MILLER Jr., G. T. (1990) Living in the Environment. Belmont, CA, Wadsworth, 620 p.

MINISTÉRIO DA AGRICULTURA, (1995) Legislação federal de agrotóxicos e afins. Brasília - Departamento de Defesa e Inspeção Vegetal. 120 p..

MINISTÉRIO DO MEIO AMBIENTE, (1999) " Agenda 21 Brasileira - Área Temática: Agricultura Sustentável ", Consórcio Emílio Goeldi, Documento de Trabalho (resumo do documento final), 36 p. [on line] Disponível em http://www.atech.br/agenda21.as/final2a.htm

MUITA FORÇA para instituir receituário agronômico. Dirigente Rural. São Paulo, 20(1-2):12-19, janeiro/fevereiro, 1981.

NAIDIN, Leane C. (1985) " Crescimento e competição na indústria de defensivos agrícolas no Brasil ". Rio de Janeiro, 269 p. [ Dissertação de Mestrado Universidade Federal do Rio de Janeiro]

NEVES, M.C. et alii. (1998) "Caracterização espaço-temporal do uso de agrotóxicos para o estado de São Paulo". In: ASSAD, E.D.; SANO, E.E. Sistema de informações geográficas: aplicações na agricultura. 2.ed., rev. e ampl. Brasília: Embrapa-SPI / Embrapa-CPAC, 1998. 434p..

NEWSOME, L. D. (1967) "Consequences of inseticide use on nontarget organisms" Am. Rev. Ent. 12:257-258. apud NRC (National Research Council). (2000) The future role of pesticides in US agriculture. Washington, D.C.: National Academy Press. 258 p. [on line] Disponível em http://www.nap.edu 
NICOLAU, N. M. (1985) "O uso dos agrotóxicos e a agricultura". In: SECRETARIA DE AGRICULTURA E ABASTECIMENTO DO ESTADO DE SÃO PAULO. Programa de Racionalização do Uso de Agrotóxicos. São Paulo, março, 1985

NRC (National Research Council). (2000) The future role of pesticides in US agriculture. Washington, D.C.: National Academy Press. 258 p. [on line] Disponível em http://www.nap.edu/books/0309065267/html/

OECD (1996) Activities to Reduce Pesticides Risks in OECD and Selected FAO Countries. OECD Environmental Health and Safety Publications. Series on Pesticides nº. Paris, OECD, 94p..

OERKE, E. C. et alii. (1995) Crop production and crop protection: Estimated losses in major food and cash corps. Amsterdan: Elsevier. apud YUDELMAN, M.; RATTA, Annu e NYGAARD, D. (1998) Pest Management and Food Production - Looking to the Future - - [on line] Disponível em http://www.cgiar.org/IFPRI/2020/dp/dp25.pdf

OPPTS/EPA, (1997) United States national profile on management of chemicals . Office of Prevention, Pesticides and Toxic Substances - U.S. Environmental Protection Agency. 112p. [on line] Disponível na Internet http://www.epa.gov/opppsps1/profile/index.html

PAN AMERICAN HEALTH ORGANIZATION (1993) Pesticides and health in the Americas. Environmental Series n ${ }^{\circ} 12$. Washington, D.C. PAHO, 109 p..

PANUPS Pesticide Action Network North America Update Service (1997) "World Pesticide Sales Up." panna@panna.org

PARA A ANDEF a agricultura só é viável com uso de defensivos. Informe Agropecuário, Belo Horizonte, 5 (58):151-153, outubro, 1979.

PARANÁ amplia programa para embalagem de agrotóxico. O Estado de São Paulo. São Paulo: Suplemento agrícola, maio de 1999

PASCHOAL, A. D. (1982) "Receituário Agronômico: fatores determinantes e limitantes." In: Francisco GRAZIANO NETO. coord. Uso de agrotóxicos e Receituário Agronômico. São Paulo. Agroedições. 1982. p.p. 163-170.

PASCHOAL, A.D. (1979) Pragas, praguicidas e a crise ambiental: problemas e soluções. Rio de Janeiro. Fundação Getúlio Vargas, 106 p..

PESSANHA, B. M. R. (1982) "O defensivo agrícola." In: Francisco GRAZIANO NETO. coord. Uso de agrotóxicos e Receituário Agronômico. São Paulo. Agroedições. p.p. 7-35.

PESSANHA, B. M. R. e MENEZES, F. A. F. (1985) "A questão dos agrotóxicos". Agroanalysis, 9(9):2-22, setembro, 1985. 
PINCH, T. F. \& BIJKER, W.E. (1989) " The Social Construction of Facts and Artifacts: Or How the Sociology of Science and the Sociology of Technology Might Benefit Each Other ". In: BIJKER, W.E.; HUGHES, T.P. \& PINCH, T.F. The Social Construction of Technological Systems - New Directions in the Sociology and History of Technology, Massachusetts: MIT Press, p.p. 17-50.

PIMENTEL, David (1993) "Environmental and economic impacts of reducing U.S. agricultural pesticide use." In: David PIMENTEL \& Hugh LEHMAN. Eds. The pesticide question - environmental, economics, and ethics. New York. Chapman \& Hall. Inc. p.p. 223-278.

(1995) Pest management, food security, and the environment: History and current status. Paper presented at the IFPRI workshop "Pest Management, Food Security, and the Environment: The Future to 2020." Washington, D.C., May 1011.

(1997) Personal correspondence. Dezembro. In: YUDELMAN, M.; RATTA, Annu e NYGAARD, D. (1998) " Pest Management and Food Production - Looking to the Future ". - [on line] Disponível em http://www.cgiar.org/IFPRI/2020/dp/dp25.pdf

PINHEIRO, S; AURVALlE, A. \& GUAZZELLI, M. J. (1985) Agropecuária sem veneno. Porto Alegre: L\&PM ed. 128 p..

PINHEIRO, S.; NASR, N.Y. \& LUZ, D. (1993) A agricultura ecológica e a máfia dos agrotóxicos no Brasil. Porto Alegre: Edição dos Autores. 338 p..

PORTO, P. R. F., "Embalagens de agrotóxicos, receituário agronômico, responsabilidade civil, penal e administrativa". / Apresentado ao V Congresso Nacional de Agrotóxicos e Receituário Agronômico. Rio de Janeiro, 2000.

PRODUÇÃO nacional em tempo de expansão. Dirigente Rural. 9(17):24-30, set./out., 1978.

RAMOS, H. H. et alii. (1999) "Condições de trabalho com agrotóxicos no Estado de São Paulo". CIPA - Caderno Informativo de prevenção de acidentes. 20(238):3648 , setembro.

RECEITA agronômica: nova ameaça ao setor. Química e Derivados. São Paulo, [S.N.]:12, julho, 1979.

RECEITUÁRIO Agronômico corre risco de ser descaracterizado. O Estado. Florianópolis: Suplemento Rural, 31 maio, 1985, p.10.

RECEITUÁRIO Agronômico: implantar e mudar. Jornal do Engenheiro Agrônomo. São Paulo, 20(185):2, outubro/novembro, 1990. 
RECEITUÁRIO agronômico será obrigatório. O Estado de São Paulo., São Paulo: Suplemento Agrícola, 10 julho, 1985, p.3

RECEITUÁRIO existe para preservar a vida. A Granja. Porto Alegre, :22-23, mar./abr., 1989.

RECEITUÁRIO para defensivo depende do governo. Folha de São Paulo. São Paulo: Agrofolha, 18 de abril, 1989, p.G-3

REPÓRTER "compra" receita em loja e leva agrotóxico capaz de matar 35. Folha de São Paulo. São Paulo: Caderno Cotidiano, 19 de janeiro, 1992, p.1.

RIO GRANDE DO SUL. Leis, etc, (1982) Decreto n. 30.787 de 22 de julho de 1982. Dispõe sobre o uso de defensivos clorados no estado. Diário Oficial do Estado, Porto Alegre, 22 jul., p.1.

RIO GRANDE DO SUL. Leis, etc, (1982) Decreto n. 30.811 de 23 de agosto de 1982. Dispõe sobre o comércio de defensivos agrícolas no estado. Diário Oficial do Estado, Porto Alegre, 23 ago., p.1.

RIO GRANDE DO SUL. Leis, etc, (1982) Lei n. 7.747 de 22 de dezembro de 1982. Dispõe sobre o controle de agrotóxicos e outros biocidas a nível estadual e dá outras providências. Diário Oficial do Estado, Porto Alegre, 22 dez., p.1.

RÜEGG, E. F. et alii (1991) Impacto dos agrotóxicos sobre o ambiente, a saúde e a sociedade. São Paulo: Cone ed. 96 p.

SAMPAIO, Daiser Paulo (1978) "Receituário Agronômico: conceito, objetivos e elaboração." In: UNIVERSIDADE FEDERAL DE PELOTAS. $1^{\circ}$ Curso sobre Fundamentos do Receituário Agronômico. Pelotas. Centro de Treinamento e Informação do Sul (CETREISUL), 1978 (apostila)

SAMPAIO, D. P. \& GUERRA, M. S. (1978) "Fatores limitantes da prescrição técnica." In: UNIVERSIDADE FEDERAL DE PELOTAS. $1^{\circ}$ Curso sobre Fundamentos do Receituário Agronômico. Pelotas. Centro de Treinamento e Informação do Sul (CETREISUL), 1978 (apostila)

SÃO PAULO (Estado). Leis, etc, (1984) Lei n. 4.002 de 05 de janeiro de 1984. Dispõe sobre a distribuição e comercialização de produtos agrotóxicos e outros biocidas no território do Estado de São Paulo. CREA-SP: Coletânea de legislação profissional. São Paulo, p.84-7.

SÃO PAULO (Estado). Leis, etc, (1986) Lei n. 5.032 de 15 de abril de 1986. Altera a Lei n. 4.002 de 5 de janeiro de 1984, que dispõe sobre a distribuição e comercialização de produtos agrotóxicos e outros biocidas no território do Estado de São Paulo. CREA-SP: Coletânea de legislação profissional. São Paulo, p.88-92. 
SÃO PAULO (Estado). Leis, etc, (1989) Decreto n. 30.565 de 10 de outubro de 1989. Aprova o Regulamento que fixa os procedimentos relativos a cadastramento, fiscalização do uso e sua aplicação, imposição de penalidades e recursos na distribuição e comercialização de produtos agrotóxicos, seus componentes e afins, no território do Estado de São Paulo, e dá outras providências. CREA-SP: Coletânea de legislação profissional. São Paulo, p.93-100.

SÃO PAULO (Estado). Leis, etc, (1990) Decreto n. 31.132 de 5 de janeiro de 1989. Altera a redação do artigo $2^{\circ}$ do Decreto n. 30.565, de 10 de outubro de 1989, e dá outras providências. CREA-SP: Coletânea de legislação profissional. São Paulo, p.101-6.

SÃO PAULO (Estado). Leis, etc, (1999) Decreto n. 44.038 de 15 de junho de 1999. Aprova Regulamento fixando os procedimentos relativos ao cadastramento e fiscalização do uso, da aplicação, da distribuição e comercialização de produtos agrotóxicos, seus componentes e afins, no território do Estado de São Paulo e dá providências correlatas. Diário Oficial do Estado, São Paulo, 16 de junho de 1999.

SECCHI, Valdir Antonio (1986) "Receituário Agronômico na Extensão Rural." Informativo Técnico COPER - Série: Defensivos Agrícolas Porto Alegre, 33(22): $9 \mathrm{p}$.

SECRETARIA DE AGRICULTURA E ABASTECIMENTO DO ESTADO DE SÃO PAULO.(1985) Programa de Racionalização do Uso de Agrotóxicos. São Paulo.

SILVEIRA, José Maria F. J. e FUTINO, Ana Maria. (1990) " O Plano Nacional de Defensivos Agrícolas e a criação da indústria brasileira de defensivos ". Agricultura em São Paulo. São Paulo, 37(3):129-146.

SINDICATO NACIONAL DA INDÚSTRIA DE DEFENSIVOS AGRÍCOLAS SINDAG. "Vendas de Defensivos Agrícolas-1990/94 ". SINDAG, s/d. 9 p. [Mimeogr.].

SINITOX. (1993) Estatística Anual de Casos de Intoxicação e Envenenamento. Brasil, 1992. Rio de Janeiro, 46p..

(1995) Estatística Anual de Casos de Intoxicação e Envenenamento. Brasil, 1993. Rio de Janeiro, 74p..

(1996) Estatística Anual de Casos de Intoxicação e Envenenamento. Brasil, 1994. Rio de Janeiro, 105p..

(1997) Estatística Anual de Casos de Intoxicação e Envenenamento. Brasil, 1995. Rio de Janeiro, 108p..

(1998) Estatística Anual de Casos de Intoxicação e Envenenamento. Brasil, 1996. Rio de Janeiro, 72p.. 
(1998) Estatística Anual de Casos de Intoxicação e Envenenamento. Brasil, 1997. Rio de Janeiro, 80p..

(1999) Estatística anual de casos de intoxicação e envenenamento . - Brasil - Fundação Oswaldo Cruz, 1998. [on line]. Disponível na Internet via www URL:http://www.fiocruz.br/cict/oquee/estrut/dect/sinitox/

SKALISZ, Reinaldo Onofre (2000) "Receita Agronômica: avaliação e perspectivas". / Apresentado ao $\mathrm{V}$ Congresso Nacional de Agrotóxicos e Receituário Agronômico. Rio de Janeiro, agosto, 2000.

SÓ COM RECEITA Revista Raízes. 60:68-69, São Paulo, dezembro, 1980

SUDERHSA (1998) "Programa para destinação das embalagens de agrotóxicos utilizadas no Estado do Paraná" - Folheto de divulgação, Curitiba - 19p..

UNIVERSIDADE FEDERAL DE PELOTAS. $1^{\circ}$ Curso sobre Fundamentos do Receituário Agronômico. Pelotas. Centro de Treinamento e Informação do Sul (CETREISUL), 1978 (apostila)

VAAGT, G. (1995) " O que a AGENDA 21 especifica para a proteção vegetal - Uma base para discussão " . GTZ - Deutsche Gesellschaft für Technische Zusammenarbeit GmbH, 27 p. [Mimeogr.].

VESSURI, H.M.C. (1991) " Perspectivas recientes em el estudio social de la ciência ", Interciencia, vol.16, $\mathrm{n}^{\mathrm{o}} 2$, pp. 60-68.

VICENTE, M.C. M. et alii (1998) " Perfil do aplicador de agrotóxicos na agricultura paulista " Informações Econômicas. São Paulo: 4(11): 35-59. novembro.

VIOLA, E. e LEIS, H. (1997) " A agenda 21 diante dos desafios da governabilidade, das políticas públicas, e do papel das ONG's ", In: CORDANI, U. et alii. (orgs.) Rio 92 - Cinco Anos Depois, IEA.

WAQUIM, Jorge Salim (2000) "Agrotóxicos e o Mercosul". / Apresentado ao V Congresso Nacional de Agrotóxicos e Receituário Agronômico. Rio de Janeiro, agosto, 2000.

WINNER, Langdon (1983) " Do Artifacts Have Politics? ", In: D.MacKenzie et al. (eds.), The Social Shaping of Technology, Philadelphia: Open University Press, 1985.[on line] Disponível em http://www.oei.org.co/cts/winner.htm

WORLD HEALTH ORGANIZATION. (1990) " Public health impact of pesticides used in agriculture ". Geneva, 1209 p.. 
YUDELMAN, M.; RATTA, Annu e NYGAARD, D. (1998) " Pest Management and Food Production - Looking to the Future ". - [on line] Disponível em http://www.cgiar.org/IFPRI/2020/dp/dp25.pdf 